\title{
EL SUJETO DESCENTRADO EN LA OBRA DE LEÓN DE GREIFF
}

\author{
Autor \\ ÓSCAR SALAMANCA
}

Tesis para optar al título de Magíster en Estética y Teoría de las Artes

\author{
Directora \\ MARÍA DE LOS ÁNGELES DE RUEDA \\ Docente académica
}

\author{
UNIVERSIDAD NACIONAL DE LA PLATA \\ FACULTAD DE BELLAS ARTES \\ MAESTRÍA EN ESTÉTICA Y TEORÍA DE LAS ARTES \\ LA PLATA, PROVINCIA DE BUENOS AIRES, ARGENTINA \\ 2013
}




\section{TABLA DE CONTENIDO}

3

INICIO: OBERTURA

38

EXPOSICIÓN DEL TEMA: POÉTICA DEL DESCENTRAMIENTO EN LA OBRA DE LEÓN DE GREIFF

43

VARIACIÓN 1: CRÍTICA DE LA CONCEPCIÓN MODERNISTA DE LA POESÍA

60

VARIACIÓN 2: POÉTICA DE LA DIVAGACIÓN

99

VARIACIÓN 3: LOS AVATARES DEL YO

137

CODA: LA CATEGORÍA HISTÓRICA DE LA VANGUARDIA EN LEÓN DE GREIFF

166

CIERRE: EPÍLOGO

171

BIBLIOGRAFÍA 


\section{INICIO: OBERTURA}

La obra del poeta colombiano León de Greiff surge en la transición entre el modernismo y la vanguardia en América Latina, y presenta en concordancia una estética de doble carácter conformada por aspectos de una y otra tendencia ${ }^{1}$. Mucho se ha hablado, en la crítica más tradicional, sobre su pertenencia exclusiva al modernismo, debido a sus imágenes poéticas, referencias culturales o la métrica de sus versos, cercanas muchas veces a los postulados de este movimiento finisecular, e indiscutibles hasta para los defensores más entusiastas de su clasificación en la vanguardia. No obstante, es evidente que el conjunto de su obra no puede ser catalogado de modernista, considerando la multitud de factores que trascienden este movimiento y contradicen no pocas veces aquella postura tradicional. Si bien es cierto que muchos de sus poemas célebres se pueden considerar modernistas, también es cierto

\footnotetext{
${ }^{1}$ Conviene aclarar desde ahora qué definiciones de "modernismo" y "vanguardia" se emplearán en este trabajo, así como otros conceptos también recurrentes a lo largo de él. Con "modernismo" se hace referencia al movimiento hispanoamericano de la segunda mitad del siglo XIX, entre cuyos máximos exponentes figura Rubén Darío, que comporta una renovación de las letras en castellano, motivada principalmente por la mirada a contextos diferentes de la tradición española, sobre todo la literatura francesa simbolista y parnasiana. El "esteticismo" refiere aquí, más que el movimiento específicamente inglés correspondiente al "decadentismo" francés, la actitud general del arte más avanzado de finales del siglo XIX, donde prevalece la idea del arte por el arte mismo y, por lo tanto, de su autonomía radical. La noción de lo "finisecular" se aplica al contexto de estas poéticas de fin de siglo, tanto hispanoamericanas como europeas. No sobra recordar que "modernismo", "simbolismo", "parnasianismo", "esteticismo", "decadentismo" y "poesía finisecular" son sólo algunas de las tantas manifestaciones de la tradición de la "modernidad", propia de toda la civilización occidental, que a grandes rasgos consiste en un conjunto de ideas y conceptos sobre el sujeto y la razón en calidad de entidades autónomas y plenamente diferenciadas, y que cronológicamente puede enmarcarse, según la opinión más extendida, desde su origen en el racionalismo del siglo XVII hasta su aparente agotamiento a finales del siglo XIX. La "vanguardia" alude básicamente a la actitud de protesta y renovación del arte tal como fue entendido hasta esa época, y por supuesto, a los procedimientos de una u otra tendencia que contribuyeron a generar nuevos conceptos y prácticas artísticas a las puertas del siglo XX. Con "contemporáneo" se quiere denominar, precisamente, el contexto del arte durante y después de esta renovación, puesto que, si bien desde cierta perspectiva la vanguardia "fracasó" en la consecución de su proyecto fundamental, esto es, la superación de la distancia entre arte y sociedad, también constituyó un punto de quiebre esencial que modificó por completo la conceptualización de la creación estética y sentó las bases para las inquietudes y los avances del arte a lo largo del siglo anterior. Con respecto a la alternancia indiferenciada de los términos "poesía", "literatura" y "arte", ésta sólo tendrá lugar cuando la problemática en cuestión permita llevar a cabo la ampliación conceptual correspondiente, teniendo en cuenta que la transición entre las estéticas finisecular y vanguardista afecta a los distintos estamentos del arte, y que en ocasiones, dependiendo del alcance de esa problemática específica, lo que afecta a una parte es el correlato de un fenómeno de conjunto que las afecta a todas. No obstante, se prestará especial atención a que esta indiferenciación eventual esté plenamente justificada por el enfoque de las conceptualizaciones empleadas o por los componentes específicos de la obra en estudio.
} 
que muchos otros, quizá menos conocidos que aquellos, se rebelan contra esta clasificación y demandan la perspectiva de estéticas más contemporáneas. No es conveniente, desde el punto de vista del análisis, reducir la totalidad de una obra tan heterogénea a los postulados a veces fijos de una u otra tendencia literaria. Por el contrario, es necesario indagar en esos componentes en particular y establecer desde ellos las referencias necesarias a los ámbitos estéticos e históricos en cuestión, confiando en que la obra misma nos proporcione claves de sus conexiones con las poéticas en las que se enmarca, en este caso la poética finisecular y los inicios de la literatura contemporánea en el continente.

Sin perjuicio de la convicción anterior, es preciso adoptar una postura teórica que estructure el análisis de esta poesía, que determine su enfoque y contribuya a desarrollar el problema de estudio. Esta postura se centrará en las prácticas vanguardistas y las implicaciones de algunos procedimientos respecto a una poética contemporánea, haciendo justicia a los elementos de avanzada que gran parte de la crítica se ha empeñado en ignorar y frente a los cuales ha optado a veces por el camino expedito de la simplificación. En ningún momento se desconocerá la enorme influencia del modernismo en esta poesía, pero se abordará sobre todo a modo de referencia, desde donde se precisarán aspectos más contemporáneos que trascienden ese movimiento finisecular y sólo pueden ser explicados a partir de estéticas más contemporáneas. En esa perspectiva se trabajará el problema de estudio en la obra del poeta, el descentramiento del sujeto a partir del procedimiento de la ironía, instrumento no solamente en contra de un medio intelectual adverso (de rezagos señoriales e incipientes valores burgueses, donde la poesía moderna es relegada a una doble marginalidad: por expresión "decadente" en el primer caso y por carencia de utilidad en el segundo), sino también contra la poesía misma, en una autocrítica que desestabiliza el sujeto poético y lo disgrega en múltiples heterónimos e identidades indefinidas. Con esta hipótesis se intenta reivindicar en De Greiff una nueva actitud frente a la poesía en la literatura colombiana de la primera mitad del siglo $\mathrm{XX}$, desde una poética de vanguardia que se opone a las tradiciones estéticas del medio intelectual de entonces, dominado por la literatura centenarista conservadora y por un modernismo ya legitimado que había perdido su potencial inicial de protesta. 
La imprecisión que se percibe en buena parte de la crítica sobre la poesía de De Greiff, en torno a la definición de su carácter modernista o vanguardista, es el fruto del carácter sumamente heterogéneo de su obra, y por ello, de la dificultad al momento de clasificarla en las tendencias más definidas de su época. Obras literarias como la del poeta Guillermo Valencia no plantean mayores dificultades respecto de esta clasificación, pues se componen en su totalidad de intenciones y rasgos estilísticos propios del modernismo, sin sugerir siquiera aspectos que intenten trascender ese orden estético; pero obras como la de De Greiff resultan mucho más problemáticas, puesto que presentan numerosos indicios de una poética que supera el ámbito de la estética modernista. Factores de primer orden como la ironía contra la poesía y el sujeto poético, la ridiculización de nociones decimonónicas de la poesía, la tendencia a la divagación discursiva en oposición a la estabilidad de la expresión del sujeto de la literatura finisecular, la disgregación del poeta en múltiples heterónimos e identidades no definidas, además de otros como la proliferación inusitada de arcaísmos, neologismos o extranjerismos idiomáticos que amplían el repertorio de recursos expresivos, y la articulación entre los ámbitos de la poesía y la música, anunciada por el simbolismo pero aquí efectuada con técnicas que superan toda formulación anterior, son muestras inexcusables de una estética que, si bien no puede ni debe asociarse por completo a las vanguardias europeas, escapa a los rasgos fundamentales de un modernismo que todavía no indagaba en esos aspectos, mucho más propios de inquietudes estéticas contemporáneas.

Ahora bien, es preciso acordar qué concepción de la vanguardia se manejará en el estudio, a fin de evitar la simple homologación de los postulados vanguardistas europeos a los procesos históricos y estéticos de la literatura hispanoamericana -práctica más usual de lo que sería recomendable-, con lo cual no sólo se ha desconocido que en nuestro continente existen condiciones muy específicas que marcan nuestra evolución en todos los ámbitos, sino que se ha generado una especie de clasificación exógena para fenómenos internos, según la cual sólo es vanguardia aquella manifestación que se adecúa dócilmente a lo estipulado por su contraparte europea. Si bien es cierto que las vanguardias en nuestro continente están influenciadas por las conquistas de la poesía y el arte en general de Europa a inicios del siglo XX, no es menos cierto que las condiciones de esta protesta en América Latina se enmarcan en una situación social y estética propia, que no corresponde del todo y 
sin reserva alguna a la evolución de las letras francesas o alemanas. La actitud vanguardista fue en principio una revuelta contra un orden social que prescribía una relación muy específica entre el arte y la sociedad; pero mientras en Europa ese orden social estaba conformado por una sociedad burguesa ya plenamente consolidada, en América Latina aún era incipiente la asimilación de las relaciones de producción y los valores de la burguesía, instaurados gradualmente sobre los restos de un orden señorial que debe analizarse con cuidado antes de postularse el carácter o los objetivos de la protesta vanguardista, y sobre todo antes de pretender que en nuestro continente las condiciones de protesta son por completo idénticas a las del continente europeo. Si en Italia, Francia o Alemania la revuelta se produce bajo unas condiciones de producción y organización social de una burguesía dominante desde hace décadas, y que entonces alcanza su mayor grado de esplendor, en nuestros países es preciso detenerse en los rezagos de un orden señorial aún vigente en cierto modo, que hunde sus raíces en las relaciones sociales y productivas de la Colonia, así como en las paulatinas modificaciones introducidas por los valores de la burguesía, que sólo desde finales del siglo XIX se manifiestan en la literatura y el arte en general con su potencial de renovación y gestación de una actitud moderna. Por otra parte, también es importante no subvalorar la importancia de estos valores burgueses aún incipientes en la conformación de una nueva ideología en el arte y el medio intelectual del continente, aunque todavía no sean determinantes en las formas de producción y la organización social, como señala Rafael Gutiérrez Girardot. Esta situación, como todas las fundamentales para la evolución de nuestra sociedad, debe examinarse en atención a las condiciones específicas de los países latinoamericanos. La vanguardia en el continente se produce en circunstancias complejas y un tanto contradictorias. Si bien está inspirada en el proceso histórico de la literatura occidental, que en aquella época irradia fuertemente desde las sociedades europeas, se enmarca en condiciones estéticas específicas que de ningún modo pueden equiparase al contexto europeo, y debe ser analizada con base en esa convicción, con el fin de no recaer en equívocos que desvirtúan las cualidades específicas de nuestra literatura y la definen exclusivamente en virtud de su semejanza o grado de parentesco con otras literaturas, necesarias para el análisis pero no homologables sin reparo alguno. En este sentido, la poesía más vanguardista de De Greiff, aquella que escapa a las caracterizaciones de la estética modernista, sin permitirse ser tampoco la simple reproducción de un recetario 
europeo de avanzada, plantea interesantes cuestiones acerca del medio intelectual contra el que se ejerce la protesta, y deja un importante legado para reconstruir críticamente el inicio de la literatura contemporánea en nuestro continente.

Este trabajo indagará en algunas problemáticas de esta poesía que ponen en evidencia su ruptura con el medio literario de la época, no solamente respecto a los valores burgueses que ya se anuncian en el continente -aunque de forma paradójica, pues son esos valores los que le proporcionan los conceptos y las herramientas de su crítica, como en el caso de los escritores modernistas cuando se lanzan en contra de la sociedad burguesa que, de la misma forma, hace posible su actitud de protesta-, sino también a los valores tradicionales de carácter señorial que determinan buena parte del gusto literario de entonces, todo lo cual se manifiesta en Colombia como un vínculo entre el hispanismo patriarcal de Luis María Mora o Tomás Rueda Vargas, y el modernismo epigonal de Valencia elevado a la categoría de canto oficial de la república ${ }^{2}$. El resultado de esta doble ruptura es heterogéneo y muchas veces contradictorio; es incluso paradójico, acudiendo a uno de los términos predilectos del poeta. De Greiff toma distancia de la literatura centenarista, de cuño tradicional y restaurador, por medio de las renovaciones formales del modernismo y la predilección de éste por culturas distintas a la española; pero a la vez se desliga de la concepción modernista de la poesía como el oficio elevado de un ser superior incomprendido por la sociedad. Ciertamente, el poeta en De Greiff es un ser rechazado e incomprendido, pero a diferencia de los modernistas, él mismo acepta e incluso respalda ese rechazo al lanzar contra sí mismo los dardos de su ironía. La poesía es un oficio que ha de ser impugnado. El poeta es un solitario orgulloso de su soledad, igual que en el modernismo, pero también un vagabundo que habla disparates y camina sin rumbo preciso, lo que contradice de plano la noción modernista del poeta heraldo, visionario o sacerdote. A lo sumo, es un visionario

\footnotetext{
${ }^{2}$ Mucho se ha escrito sobre la estimación de Guillermo Valencia como poeta nacional de Colombia en su época. Unos la han defendido por encontrar en su obra la manifestación más acabada del modernismo literario -aunque con el tiempo éstos han desaparecido por completo-, y otros como Rafael Gutiérrez Girardot no ven en ella más que la imitación epigonal de un modernismo lleno de referencias culturales muy refinadas pero rara vez auténticas, que lejos de desarrollar una estética original, contribuyó a consolidar la ideología de una clase señorial concebida por sí misma como la medida natural de la civilización y el buen gusto. Más adelante profundizaremos en las tesis de Gutiérrez Girardot y retomaremos esta problemática del medio literario colombiano de la primera mitad de siglo - del cual el mencionado poeta y después renombrado político fue figura señera-, para caracterizar el ambiente intelectual en que surge De Greiff y precisar los objetivos y alcances de su protesta.
} 
que no cree en sus propias visiones, un heraldo que no sólo no tiene a quién guiar, sino que él mismo está extraviado. Hay quien puede ver en esto una última manifestación del modernismo, la intensificación de la soledad orgullosa hasta el extremo del desprecio a sí mismo. Pero en esta autocrítica de la poesía ya hay una diferencia notable respecto a la convicción de autosuficiencia que profesa el modernismo, no sólo porque es evidente que ya no hay manifestaciones culturales "supremas", sino porque la autocrítica se extiende a la identidad del sujeto que se expresa a través de esa poesía. El destierro del poeta de su antiguo reino sagrado es irreversible, y al verse lanzado a la hostilidad de una sociedad en que no hay más compañía que la de sus propias fantasías, se ve abocado al cuestionamiento de su subjetividad, su descomposición en múltiples personalidades que encarnan diferentes maneras de asimilar el mundo y a ellas mismas. Este descentramiento subjetivo provoca la alteración de una identidad que hasta antes de la poesía vanguardista había sido unívoca, en favor de sujetos múltiples que invaden la literatura sólo desde la época contemporánea ${ }^{3}$. Se establece así una oposición dialéctica entre la poética finisecular y la vanguardia del siglo $\mathrm{XX}$, donde al conflicto entre arte y sociedad burguesa en la primera se suma la crítica del sujeto como configurador de sentido en la segunda, un sujeto que constituye, en últimas, la base de la civilización moderna. La poesía se inspira, por lo tanto, en el sentimiento de desarraigo propio de la poética finisecular, pero en lugar de pretender restaurar un antiguo privilegio, acepta ese desarraigo y se incorpora a las dinámicas de despersonalización de la contemporaneidad.

El estudio se realizará entonces desde dos perspectivas complementarias: el procedimiento de la ironía como factor de desestabilización de la poesía, y la consiguiente fragmentación del sujeto que se configura en esa poesía. El cuestionamiento de la poesía como expresión “suprema" se convierte en el cuestionamiento del sujeto que allí se expresa. Se controvierte

\footnotetext{
${ }^{3}$ El tema del sujeto descentrado en el ámbito del pensamiento se remonta a su formulación, con los mismos términos, en la teoría de Freud, donde el sujeto es, en paráfrasis de Albrecht Wellmer, "la encrucijada de fuerzas psíquicas y sociales antes que dueño de esas fuerzas; platea desde la que asistir a una cadena de conflictos, antes que director de un drama o autor de una historia" (Wellmer 75). Más que abordar desde el inicio la teoría específica del psicoanálisis y extraer de allí elementos oportunos para esclarecer intenciones o logros de la poesía en De Greiff, se desarrollará esa idea, sobre todo, a partir de esta misma poesía: desde su tratamiento fragmentario del Yo y en relación con teorías propiamente estéticas que contribuyan a su análisis en un contexto de vanguardia. En capítulos posteriores se señalarán sus vínculos con el pensamiento de Freud, y desde allí se la pondrá en diálogo con tesis de Wellmer y Christoph Menke sobre el tema de la subversión de la razón en el arte de vanguardia y la crítica general al sujeto de la modernidad.
} 
no sólo cierto idealismo aún presente en la poesía finisecular, sino la tradición moderna que asegura la existencia de una subjetividad estable. El vínculo entre estos distanciamientos está dado por la escritura como confrontación de ideas tradicionales de la poesía, y al mismo tiempo como el lugar de expresión de diferentes subjetividades. El cuestionamiento de la poesía está vinculado al cuestionamiento del sujeto que la configura. La soledad es el espacio donde cobra existencia y se expresa la multiplicidad del ser. No sólo se acepta la pérdida de la función de la poesía como verdad y expresión de un sentir colectivo, sino que se profundiza en la modificación de su estatus social y estético a través del cuestionamiento del sujeto unívoco. El objeto de esta crítica es la concepción moderna de la poesía, tanto en la perspectiva de la tradición clásica y romántica que le asignaba funciones de cohesión social, como en la derivada de la tradición occidental en general, fuertemente influenciada por la filosofía del sujeto. Las inquietudes de esta poesía provienen entonces de nociones modernistas sobre la pérdida del ascendente social del arte en el sistema de valores de la burguesía, pero se resuelven con la aceptación de esa modificación y la profundización de la autocrítica en favor de concepciones más vanguardistas. Esta doble naturaleza incide en la presencia de aspectos tradicionales y de avanzada que interactúan constantemente y han de ser interpretados según esa mirada complementaria. Factores recurrentes en esta poesía, como el rescate de un lenguaje castizo, la métrica clásica o la retórica modernista, tan socorridos por quienes no encuentran aquí sino una prolongación de la poética finisecular, deben examinarse en un enfoque dialógico que los confronte con factores no tradicionales e igual o a veces más recurrentes, como la profusión de neologismos, la incorporación audaz de formas musicales y las figuras retóricas ya contemporáneas. Es necesario replantear el estudio de una obra excesivamente interpretada según la poética modernista, y contribuir al número creciente de estudios que ya evidencian en ella rasgos del todo vanguardistas. La presencia de estos rasgos son difícilmente objetables, pese a décadas de aproximaciones sin una base conceptual lo bastante sólida ni apartada de una tradición que no sobrepasaba las propuestas y los logros de la poesía finisecular. La carencia de puntos de vista para aproximarse a esta obra delata la insuficiencia de gran parte de la crítica ejercida durante tanto tiempo, algo que por fortuna ha comenzado a revertirse. Así pues, hay que trabajar en la distinción de los aspectos tradicionales que vinculan al poeta con la estética finisecular, y en el análisis de aquellos que pertenecen de lleno a las corrientes de vanguardia, con el fin 
de precisar más el lugar que ocupa en la historia de la literatura colombiana y en los inicios de la literatura contemporánea en el continente.

Las fuentes teóricas que se manejarán provienen de autores europeos e hispanoamericanos, enfocados sobre todo en el período histórico que constituye el origen de las vanguardias. Debido a la importancia de escuelas como el simbolismo en la concepción de esta obra, fundamental en su inspiración modernista, se acudirá también a estudios enfocados en las poéticas de fin de siglo, tanto del contexto europeo, esencial en la formación literaria del poeta, como del latinoamericano, espacio concreto donde se despliega su creación. Entre los estudios sobre la vanguardia, es imprescindible la reflexión de Peter Bürger acerca de rupturas concretas de ésta frente al arte burgués desarrollado desde el renacimiento, como la autocrítica o la oposición a la organicidad de la obra. Así mismo, planteamientos como la progresiva negación del sentido o el cuestionamiento del sujeto como punto de referencia de la razón, de Theodor Adorno y Max Horkheimer, son también adecuados para examinar la escritura en De Greiff, a veces más inclinada a la poetización por la palabra misma en una subjetividad conflictiva, que a la comunicación de un sentido "externo" determinado o a la representación de una realidad fuera de ella misma. Postulados como éstos, enfocados en propiedades del arte moderno opuestos a la concepción clásica de la representación, se abordarán también en la perspectiva de Albrecht Wellmer, en su estudio sobre la dialéctica de la modernidad y la posmodernidad, un escenario muy oportuno para el análisis de una poesía que se nutre de estéticas finiseculares y vanguardistas, con énfasis en problemas como la crítica del sujeto, la construcción del sentido y la lógica de la identidad. Surge en esta dialéctica la inquietud por el papel del arte en los discursos de la modernidad, de todo punto diferente si hablamos de estética finisecular o de estética vanguardista, por cuanto una defiende el ideal burgués de la autonomía, mientras la otra se empeña en transgredir el entramado de los discursos modernos, en función de lo que Adorno llama "soberanía". El análisis de esta oposición y su superación en un concepto que integra la especificidad autónoma del arte y la transgresión soberana de los demás discursos de la razón moderna, los encontramos en los textos de Christoph Menke, que acude para ello a la negatividad estética de Adorno y la confronta con métodos de deconstrucción, principalmente en la línea de Jacques Derrida. Esta reflexión sobre la doble naturaleza del arte contemporáneo y 
su dialéctica interna es básica al momento de comprender una obra concebida como expresión autónoma, pero que emprende, no obstante, una crítica a discursos no estéticos. Esa es la clave de la relación entre lo finisecular y lo vanguardista en De Greiff. Hay que desentrañar la dialéctica de esta relación para encontrar el lugar que su poesía ocupa en la transición entre las dos estéticas, y descifrar con exactitud el carácter y los alcances de su participación en una poética de avanzada.

Se prestará especial atención a fuentes latinoamericanas que abordan estas problemáticas en el marco de las condiciones socioculturales de nuestro continente. Ensayistas como Octavio Paz o Beatriz Sarlo nos ofrecen un panorama sobre distintos procesos sociales en relación con procesos estéticos, que abarcan desde la perduración de estructuras señoriales a veces confrontadas por una incipiente burguesía, hasta las discrepancias en el campo intelectual según la teoría de los campos de Pierre Bourdieu, en el caso de Sarlo- entre defensores de lo tradicional y abanderados de lo nuevo, sin la virulencia que tuvieron en el contexto europeo, pero siempre referidas a un modelo de creación que pretendía clausurar el pasado. Sobre las condiciones históricas del surgimiento de la vanguardia y su derivación del modernismo, se acudirá a los trabajos de Gutiérrez Girardot, quien profundiza en el conflicto entre arte y una sociedad burguesa aún no consolidada en esa época pero ya perceptible en sus rasgos ideológicos. Sobre el perfil de la mentalidad latinoamericana en el cambio de siglo, importante para comprender el contexto en el que surgen los nuevos movimientos y la ruptura que conllevan, se abordará el estudio de José Luis Romero sobre las ciudades y las ideas en el continente, referido al orden señorial dominante desde la Colonia, a la manifestación de una incipiente burguesía que establece un conflicto con la sociedad tradicional, y al surgimiento de la mentalidad moderna. Por último, en cuanto a los estudios críticos de la poesía de De Greiff, se abordarán sobre todo las reflexiones de Juan Manuel Cuartas y Marie Estripeaut Bourjac, enfocadas respectivamente en la técnica de la ironía como principio de desestabilización del sujeto y en los perfiles vanguardistas de esta obra en el ambiente intelectual colombiano de principios de siglo. Sobre esto último, principalmente respecto a ciertas diferencias entre el poeta y el grupo Los Nuevos al que un tiempo perteneció, se tomarán en cuenta las precisiones de Sergio Rojas sobre perspectivas historiográficas en el arte, y se examinará desde allí la autoconciencia del proceso del arte 
hasta el siglo XIX que la vanguardia reivindica, y su presencia en este grupo en particular. Así mismo, se acudirá a los estudios de Carmen Luna Sellés y Miguel Gomes, enfocados, a partir de una base teórica sólida, en revaluaciones de la poética de De Greiff en el contexto de las estéticas de su tiempo, a modo de guía para perfilar concepciones y aproximaciones a la obra del poeta en relación con la presencia y los alcances de poéticas modernistas o vanguardistas.

Ahora bien, en atención al largo período que abarca la obra del poeta, compuesta desde la segunda década del siglo XX hasta los años setenta, se hará, en ocasiones muy específicas, una distinción cronológica entre los poemas examinados, cuando ello sea necesario para caracterizar mejor la peculiaridad de una composición o grupo de composiciones. Es claro que gran parte de su estilo se mantiene homogéneo desde los primeros volúmenes, y así, muchas veces poemas tardíos complementan el sentido general que señalan poemas más tempranos; pero también es claro que con el paso de los años hay mayor insistencia en la idea de la nada, en la presencia y caracterización de los heterónimos, o en la disolución de relaciones convencionales entre sujeto y realidad. Todo esto tiene que ser revalorado desde una concepción diacrónica que ponga en perspectiva el conjunto de una obra tan extensa, y que deje de interpretarla como una expresión atemporal y sin evolución alguna, estancada en un modernismo en realidad no siempre presente ni comprobable.

En cuanto a los poemas examinados, éstos provienen de todos los volúmenes de poesía en verso y en prosa del autor. No obstante, debido a la extensión de su obra, se seleccionan textos claves para una ilustración adecuada de los argumentos desarrollados, siempre en atención a presentar casos muy ejemplares y significativos, pero con mucho cuidado de no considerar extensibles a la obra completa aspectos que quizá sean propios únicamente de algunos poemas. Se hace la advertencia correspondiente siempre que esto pueda suceder, y se procede a hacer la confrontación necesaria si ello es pertinente para el análisis. Se espera enfocar el estudio en casos ilustrativos que faciliten una visión de conjunto desde la perspectiva propuesta, pero sin perder de vista el carácter multifacético de la obra ni construir argumentaciones sobre casos excesivamente parciales que puedan ser rebatidos con toda facilidad desde casos opuestos. La contradicción es una constante en esta obra, y 
como tal, puede ser un arma de doble filo. Para asimilarla, es preciso no negarla ni intentar neutralizarla, y no caer, de otro modo, en totalizaciones unívocas del todo contrarias, ellas sí, a la poética del autor; por el contrario, debe ser reconocida y formulada de manera que se integre en una perspectiva amplia y acorde con la multiplicidad y el descentramiento que la misma obra formula.

Después de estas precisiones conceptuales y exposición de las principales fuentes teóricas del estudio, que desde luego no serán exclusivas pero sí determinarán el tratamiento de otras que vayan surgiendo, se formulará ahora el esquema del análisis en atención a los contenidos de cada una de sus secciones, con base en los antecedentes y aproximaciones a esta obra más pertinentes a la hora de definir un marco de estudio y su estructuración. Esta estructura está concebida de manera que sea posible la exposición de un argumento general, en este caso la presencia de la vanguardia en De Greiff, y el enfoque posterior en recursos concretos como la divagación de la escritura o el fraccionamiento de la subjetividad. Se continuará con el examen de la disolución del sujeto y la realidad en la escritura, orientada a la crítica de esta poesía respecto a la tradición moderna que, como vanguardia, confronta. La estructura se iniciará entonces con una argumentación general en torno a la vanguardia en De Greiff, continuará con la profundización en elementos vanguardistas concretos, y se complementará con el examen de la crítica así declarada a la tradición moderna del sujeto y la razón.

Cada sección del estudio será denominada de acuerdo a una forma musical académica, en concordancia con uno de los rasgos más propios de esta obra, y según las posibilidades que cada una pueda brindar en el desarrollo del tema. En este punto se parte de la convicción de que el objeto artístico examinado puede a veces proporcionar las claves para la estructura de su propio estudio. Esta obra presenta una elaborada articulación formal entre poesía y música, que incide de manera importante no sólo en el repertorio de términos e imágenes musicales, sino en componentes estructurales como el manejo de los contenidos, el orden compositivo, el tono del lenguaje, el ritmo de enunciación, la reiteración de motivos, los 
énfasis más o menos destacados y los múltiples desarrollos de un mismo tema, entre otros aspectos $^{4}$. Al retomar esta articulación se intenta aprovechar uno de los máximos logros de esta poesía y trasladarlo al ámbito de su interpretación. No obstante, esta suerte de homologación está también inspirada, casi de modo textual pero con notables variaciones, en la estructuración del análisis de la modernidad y la posmodernidad en los estudios ya mencionados de Wellmer, donde se emplean secciones como la obertura, la exposición y el desarrollo, para abordar la crítica de la razón desde esquemas alternativos a la sistematicidad expositiva de un racionalismo que precisamente está en cuestión. En el caso de De Greiff, este esquema permite integrar elementos heterogéneos pero concomitantes hacia una misma intención estética, como las subjetividades o las formas estilísticas que aparecen y desaparecen en su escritura sin una coherencia o sistematicidad evidente. Aquí, la contradicción es una constante, casi podríamos decir la única coherencia, y la escasa disposición de la crítica al momento de asimilarla bien puede ser el origen del número abundante de estudios que, a pesar de examinar su objeto de manera concienzuda, terminan por contradecirse de plano los unos a los otros.

Para precisar más el carácter contradictorio de la crítica sobre De Greiff, abordemos ahora el tema de los antecedentes, donde las discrepancias son tan múltiples y contradictorias como las mismas subjetividades que el poeta integra en su escritura: el cometido de la desvinculación de puntos de vista se ha logrado, podría decirse, en más de un sentido. La crítica desarrollada, algunos de cuyos exponentes más importantes se resumen aquí, es en grado sumo heterogénea, pues en casi un siglo este poeta de formas y apariencias múltiples

\footnotetext{
${ }^{4}$ Esta articulación se basa en la convicción de que "La Poesía, la Música son una sola Ella" (De Greiff, Obras 513). La articulación de poesía y música es uno de los temas más estudiados en la crítica sobre De Greiff, y como sucede en casi todos esos temas, aquí también se han suscitado diferentes y contradictorios juicios. Por un lado, hay quienes asocian este procedimiento con anhelos simbolistas de correspondencia entre las dos artes, sobre todo a partir de Verlaine, y por ello lo definen como un recurso finisecular. Por otro, hay quienes no dudan en catalogar este recurso como vanguardista. Así, Stephen Mohler, sin perjuicio de aludir también al poeta francés, y retomando el concepto de "sinfonismo" empleado por Juan Felipe Toruño, asegura que, entre los -ismos de la vanguardia, "el 'sinfonismo' de León de Greiff merece tanta consideración y admiración como los más reconocidos de ellos. En la poesía sinfónica degreiffiana la música penetra la estructura, el contenido temático y la imaginería" (Mohler 271-272). Sin profundizar en la controversia sobre el carácter vanguardista o simbolista de esta articulación -aunque dejando claro que no basta con que una poesía retome anhelos de escuelas anteriores para identificarse del todo con ellas, pues la sola materialización, en este caso además de manera tan singular, de lo que en otra época fue sólo aspiración, ya establece una distancia inconmensurable respecto a ellas-, se incorporará el procedimiento en la estructura de este trabajo, por medio de una nomenclatura acorde y que se adecúe de la mejor manera a sus propósitos argumentativos.
} 
ha suscitado posiciones no menos múltiples y en muchas ocasiones divergentes, respecto a la manera de abordar e interpretar su estética y al lugar que su figura ocupa en la historia de la literatura colombiana ${ }^{5}$. Se ha hablado, a veces, de una poesía modernista inspirada en los modelos clásicos de la literatura española, pero asimismo de una poesía vanguardista tan combativa como la de Huidobro o Vallejo. Críticos como Eduardo Castillo, Jorge Zalamea y Rafael Maya, los dos últimos compañeros del poeta en el grupo Los Nuevos, asocian su obra con las derivaciones simbolistas del modernismo hispanoamericano. Castillo, hasta cierto punto modernista pero más bien adscrito a la llamada generación del Centenario, un movimiento de tendencias estéticas e ideológicas conservadoras, enfoca su juicio sobre el poeta, cuya obra le resulta "irreverente, irónica, suelta y golpeante", en su multiplicidad desconcertante e indefinible, al señalar que es un "artista contradictorio, paradójico y a veces extravagante y absurdo que escapa a todo ensayo de captación crítica, a toda tentativa para abarcar los diversos aspectos y modalidades de su talento" ". Convencido del todo de esa imposibilidad de definición, el crítico rehúsa profundizar en sus apreciaciones y se detiene en esa imagen caleidoscópica y en últimas imprecisa del poeta. Tampoco llegan muy lejos sus contertulios Zalamea y Maya. Para el primero, la poesía de De Greiff, en palabras de David Jiménez Panesso, realiza el "cumplimiento de la vieja alianza simbolista entre música y poesía”. En un medio literario tardíamente neorromántico y con tímidos atisbos de modernismo, De Greiff "parece destinado a llenar esos vacíos dentro de la estética modernista, en lugar de presentarse como revolucionario, heraldo de las vanguardias"7. Se destaca en Zalamea su aproximación a una estética del lector sobre la base del "elemento musical", que pone a aquél en situación de "indeterminación que lo deja

\footnotetext{
${ }^{5}$ Se exceptúan de estos antecedentes las numerosas evocaciones de la figura exótica y desconcertante del poeta, frecuentando las tertulias en cafetines olvidados hace décadas, así como los emotivos panegíricos que celebran su condición de "poeta nacional" - según el calificativo referido por Jaime García Maffla y por el cual De Greiff termina por convertirse en una especie de sucesor de Valencia-, además de otras numerosas semblanzas tan pomposas como intrascendentes para la consecución de los objetivos planteados en este análisis.

${ }^{6}$ E. Castillo, Tinta perdida, citado en Pöppel 189. En su Historia de la crítica literaria en Colombia, David Jiménez Panesso asegura que el Castillo profesador del modernismo, "poca o ninguna atención prestó a los síntomas de descomposición de la estética modernista y al advenimiento de otras formas y concepciones de la poesía. [...] En los poetas colombianos más jóvenes -en Maya, De Greiff, Umaña Bernal- vio básicamente prolongaciones de la estética modernista" (Jiménez Panesso, Historia de la crítica 165).

7 Jiménez Panesso, Historia de la crítica 169. Esta observación es pertinente al abordar e interpretar los antecedentes críticos de la obra de De Greiff, debido a que gran parte de los juicios emitidos -y en ocasiones consagrados como premisas en un medio literario cuya solidez teórica no se remite a muchas décadas atrásprovienen de imprecisiones conceptuales motivadas, en esa época, por los rezagos de una cultura retardataria o por el abierto desconocimiento, e incluso deliberada ignorancia, de las corrientes estéticas más novedosas.
} 
en disponibilidad para todas las insinuaciones, excitaciones y abusos del sonido, al margen de toda idea, a hurto de la conciencia"8. Sobresale entonces este "elemento musical" sugerente, dispuesto a través de la escritura como forma, como estructura, la cual se concibe, sin embargo, aislada del contenido, "al margen de toda idea", según la dicotomía tradicional entre forma y contenido que, en contra de lo que piensa el crítico, encuentra en la obra de De Greiff, pletórica de estructuras lingüísticas hechas contenido, una poderosa objeción. Pero la omnipresencia del modernismo como referencia literaria, ahora no sólo respecto de la poesía de De Greiff sino de la mayor parte de la poesía contemporánea a la suya, en materia de intenciones y exploraciones, llega a su culminación en el pensamiento de Rafael Maya. Según él, "la última onda del movimiento modernista no acaba en los centenaristas sino en la generación que sucedió a ésta, o sean Los Nuevos”, entre cuyos miembros - de los cuales Maya forma parte- De Greiff ha sido reconocido, por la mayor parte de la crítica, como su exponente más audaz y original, pese a que, en la opinión de Maya, su propiedad más notable sea reiterar "la canción lunática de Jules Laforgue". En un autor que concibe las vanguardias históricas de posguerra como prolongaciones decadentes de inquietudes originadas en el modernismo ${ }^{10}$, no es extraño encontrar una definición del arte "modernista" de Los Nuevos en función de categorías anteriores a la propia escuela modernista: "Este grupo, si bien representó un rompimiento político y literario en relación con los centenaristas, [...] permaneció, no obstante, fiel a ciertas escuelas del siglo pasado, como el simbolismo y el parnasianismo franceses, por una parte, y de otro lado, a la tendencia clásica, profundamente modificada por lo que hubo en el modernismo de más próximo a esta escuela" (Maya 112). En consecuencia, Los Nuevos no son más novedosos de lo que les permite su arraigo incondicionado a escuelas literarias del siglo anterior a su surgimiento, y su más destacado exponente, De Greiff, no representa mucho más para la literatura colombiana que la prolongación del esteticismo nocturnal del simbolista Laforgue, en una relación de influencias que quizá habría sido más fructífera de haberse considerado los experimentos lingüísticos y la ironía en contra de sí mismo por las cuales

\footnotetext{
${ }^{8}$ J. Zalamea, Literatura, política y arte, citado en Jiménez Panesso, Historia de la crítica 169.

${ }^{9}$ R. Maya, Los orígenes del modernismo en Colombia, citado en Jiménez Panesso, Historia de la crítica 169.

${ }^{10}$ En efecto, según Jiménez Panesso, "Rafael Maya considera que toda la anarquía moral y estética del arte de la postguerra tiene su raíz en el Modernismo. 'El futurismo, el dadaísmo, el surrealismo, todas las escuelas de vanguardia que aparecieron después de la guerra, entre los años de 1914 y 1920, estaban virtualmente contenidas en el Modernismo'" (Jiménez Panesso, Historia de la crítica 171).
} 
es reconocido el poeta francés ${ }^{11}$. Por último, en la selección de autores abocados a la interpretación modernista del poeta, es interesante encontrar a David Jiménez Panesso, crítico contemporáneo muy certero en sus apreciaciones, pero que en este caso cae también en la generalización errónea al pretender aplicar a la poesía entera de De Greiff rasgos que no siempre se presentan en ella de la misma manera o con la misma frecuencia. Jiménez Panesso no contempla la posibilidad de examinar al poeta desde parámetros distintos a la tradición del modernismo, al relacionarlo en exclusiva con figuras imprescindibles en movimientos afines como el simbolismo, en particular Laforgue, y al asegurar que "recibe esa tradición, la enriquece, la ironiza, la parodia, pero no renuncia a ella". En una apreciación que sólo es parcialmente cierta, señala que "en su obra siguen vivos casi todos los tópicos centrales de la poesía modernista: el culto al yo, la torre de marfil, el odio al filisteísmo circundante, el sentido utópico del arte, el ritmo como esencia del poema, la concepción de la imagen poética no como invención arbitraria de la fantasía sino como sugerencia de una analogía cósmica”. Más aún, afirma que "estos dos últimos rasgos, relativos al ritmo y la imagen, lo separan definitivamente de las tendencias de vanguardia, contemporáneas de sus libros iniciales" (Jiménez Panesso, Antología 36). En principio, se reincide en la referencia exclusiva a Laforgue que ya había parcializado la opinión de Maya. Pero el centro del argumento está en los elementos que se enumeran con el fin de

\footnotetext{
${ }^{11}$ Hay una imprecisión de escuelas y movimientos semejante en Luis Alzate Noreña, cuando afirma que Leo Legris es "modernista en el sentido de inconformidad" (Alzate Noreña 173), o incluso no "exacto simbolista" sino dueño de "una energía romántica o una serenidad de pensamiento" que lo alejan de la "paciencia en la labor" de esa escuela (178). La posibilidad que brinda la referencia personalizada a uno de los múltiples heterónimos del poeta no es aprovechada en absoluto, pues parece que el autor, en la época temprana de esta apreciación, se dirige a Legris lo mismo que a De Greiff. Aquí, el poeta no sólo no es vanguardista en modo alguno, sino más bien parnasiano, romántico o incluso clasicista. Con todo, hasta ahí podría justificarse su apreciación, de algún modo, en razón de las formas estéticas múltiples que el poeta pone en diálogo en su obra; lo que no se entiende muy bien es la "inconformidad" como categoría estética del modernismo, o la oposición entre "serenidad de pensamiento" y "paciencia en la labor", esta última como "una de las virtudes principales del simbolismo". Pero su desatino en identificar la originalidad y los logros del poeta llega al límite cuando, benevolente, se toma el trabajo de aconsejarle: "Haga más exactas las sensaciones, aclare más sus contornos sin aminorar la pluralidad emotiva, y su obra será precisa, fuerte, inconfundible" (182-183). Visiones como esta, sin el más mínimo sentido de la teoría estética o al menos de la poética de fin de siglo, perduraron a lo largo de mucho tiempo y contribuyeron a hacer imprecisa la visión de un poeta de obra extensa y poco fácil de leer, que propuso una escritura ajena a los parámetros hasta entonces elogiados e institucionalizados en Colombia e Hispanoamérica. En fin, quizá esta imprecisión haya sido una especie de "mal necesario" en la consumación de la estética multiforme del poeta -el mismo por el que René Uribe Ferrer se lamenta de la "impresión desfigurada" del poeta y asegura que quien lea su obra íntegra "verá que nada hay en toda ella que la acerque a las escuelas de vanguardia" (Uribe Ferrer 283)-, pues como dijo Fernando Garavito, una de las propiedades de la poesía en De Greiff es permitir a sus lectores "hacer con ella lo que quieran" (Garavito 152).
} 
corroborar la fidelidad del poeta al modernismo. El problema es que, si bien todos ellos aparecen, en efecto, en poemas de De Greiff, no son en absoluto omnipresentes en su obra, y en muchos casos son, por lo demás, reelaborados o explícitamente confrontados. El "sentido utópico del arte" es rebatido, por ejemplo, en esos versos en que "Poesía no es sino Nadería", citados por él mismo, y "la imagen poética no como invención arbitraria de la fantasía sino como sugerencia de una analogía cósmica” se cae ante construcciones como "Si lo vigente modal es poesía, no es cosa poesía, sino nicosa y embeleco gurdo y gravívolo, zurdo y frívolo, menos que dadaísta" (De Greiff, Obras 562); o bien: "Llega Sandoval, valsando. Que todo llega: hasta Sandoval. Y esto no es anejir del Refranero De Correas ni del Refranero de Sancho, sino del Refranero-Aforismario de Bogislao, del Métome-en-todo-de-Bogislao. El cual, antes de nada y después de precisamente lo contrario - pára no tanto ixerar- es un hombre, un hombrón [...]: de cuyo hecho emana el ser, él, tomado a veces, en menos de lo muy poco que vale -por bajo de lo que vale él-" (599). En realidad, contradecir a Jiménez Panesso es cosa fácil, pues en una obra tan extensa se encuentran muchas razones para, al menos, tener cautela al asegurar que el poeta está separado "definitivamente de las tendencias de vanguardia" $"$. Hay que cuidarse de estas generalizaciones tan rotundas, pues entre más lo sean más estarán expuestas a recibir fuertes objeciones de la escritura extensa, irónica, enrevesada y contradictoria del poeta.

En una línea menos tradicionalista se encuentran los autores que identifican la obra de De Greiff, sin mayores reparos, entre los movimientos literarios de vanguardia, optando por esta solución en la controversia que Orlando Rodríguez Sardiñas resume parcialmente:

\footnotetext{
${ }^{12}$ Es preciso reconocer aquí, no obstante, la afirmación de Miguel Gomes sobre el equívoco generado por el lenguaje experimental y su relación con la vanguardia: "Quienes se amparan en lo abstruso de ciertos pasajes greiffeanos para dictaminar su pertenencia a una estética reciente deberían recordar que el modernismo del Río de la Plata, con al menos dos autores de resonancias continentales -Lugones y Herrera y Reissig- se caracterizó precisamente por su barroquismo, producto, entre otras cosas, de las distonías constantes, de la mezcla de espectros lingüísticos numerosos, donde arcaísmos y neologismos, regionalismos y palabras extranjeras se sumaban para abrir un espacio dominado por la ambigüedad o, de vez en cuando, por lo francamente 'antipoético"' (Gómes 432). Es cierto que la experimentación en el lenguaje no es procedimiento exclusivo de la vanguardia, pero sí lo es, en cambio, su contextualización en nociones del arte y el artista que confrontan la tradición finisecular y moderna en general. La experimentación en De Greiff está vinculada a nociones del sujeto y de su configuración en la escritura que la hacen plenamente vanguardista en el contexto de las letras hispanoamericanas. Este argumento es, justamente, el que se desarrolla en el presente trabajo.
} 
Su extensa obra poética ha sido y sigue siendo motivo de grandes polémicas en torno a sus valores como poesía de vanguardia, dadas sus cualidades de poesía hermética y su signo intelectual revelado en su creación en el profundo conocimiento del poeta de la mitología clásica, tanto grecolatina como del norte de Europa (de donde procedía su familia), así como de la música. Todavía en la actualidad León de Greiff es uno de los poetas más discutidos y de obra más revolucionaria de la poesía hispanoamericana contemporánea”. (Rodríguez Sardiñas, “León de Greiff” 207)

Entre quienes toman partido por la denominación de vanguardista se encuentra el crítico estadounidense Stephen Mohler, quien analiza, bajo el concepto de sinfonismo ${ }^{13}$, la presencia armónica y recurrente del arte musical académico en esta poesía. Si bien anota el autor, en uno de sus estudios sobre De Greiff, que "en espíritu su poesía es una continuación del modernismo" (Mohler, "El estilo" 28), en otro pasaje le confiere aquella otra denominación más específica y autónoma, al considerar que "hay tantos -ismos en la poesía de la época vanguardista, que creemos que el 'sinfonismo' de León de Greiff merece tanta consideración y admiración como los más reconocidos de ellos. En la poesía sinfónica degreiffiana la música penetra la estructura, el contenido temático y la imaginería. Se puede decir que él ha tratado de seguir la teoría del Art poétique de Verlaine hasta sus últimas posibilidades"14. A pesar de que Mohler no evidencia otro tipo de relaciones entre De Greiff y los “-ismos" a los que hace referencia, más allá del grado de estimación que se le tributa a éstos en comparación con el que debería otorgársele a nuestro poeta, su análisis plantea una serie de innovaciones sin precedentes en materia de apertura de posibilidades estilísticas, que permite considerar esta poesía una de las más audaces de la nueva literatura hispanoamericana de la primera mitad del siglo XX. Desde su óptica, la música concurre a potenciar la expresión poética a través de múltiples estructuras inherentes a ella, pero homologables a la práctica del lenguaje bajo la acción catalizadora de una imaginación, una

\footnotetext{
${ }^{13}$ El término lo propone Juan Felipe Toruño en el artículo "Sinfonismo en la obra de León De Greiff”, en que asocia la poesía de De Greiff con la fuga, forma musical típicamente barroca, donde "la curva que es concatenación de puntos para ser líneas, es ligadura de notas con tonalidad centrífuga, iniciación o término, si es que éste puede existir en el devenir perpetuo del cosmos. Es la imitación de la potencia creadora, difundidora, arrolladora, controladora y a la vez céntrica" (Toruño 324). En esta asociación lo secunda Carlos García-Prada: "Fugas son muchos de los cantos de De Greiff: en ellas la frase temática [...] se confunde a veces con lo Absoluto, y en seguida lo niega, y no se aquieta por más de un instante, y continúa su vuelo icarino hacia playas ignotas que atraen y subyugan" (Gracía-Prada 194). Toruño se refiere a las relaciones entre la poesía y la música en la obra del poeta, pero no llega a identificarla, explícitamente y a partir de dicho argumento, con las vanguardias. Tal identificación es propia de Mohler, que al emplear el mismo concepto de Toruño, lo refuerza y le otorga mayor alcance.

${ }^{14}$ Mohler, “León de Greiff” 271-272. V. pág. 14, nota 4, del presente trabajo.
} 
erudición y una capacidad de síntesis extraordinarias. No obstante, y quizás a raíz de su minuciosidad en el estudio de la forma poética y la irrupción en ésta de componentes musicales que la impregnan de una doble naturaleza, el autor no establece relaciones teóricas de carácter más amplio que refuercen su convicción sobre el "vanguardismo" en De Greiff, con base en los postulados estéticos, políticos y vitalistas que caracterizaron a las vanguardias históricas. Por su parte, el escritor e historiador argentino Enrique Anderson Imbert sitúa al poeta entre los "más violentos, decididos y consecuentes en su afán de escandalizar", junto a César Vallejo, Vicente Huidobro y Oliverio Girondo, incuestionados nombres de la vanguardia literaria hispanoamericana: “Complejo, introvertido, sarcástico, descontento, imaginativo, con estallidos de ritmos, palabras y locuras, siempre lírico, León de Greiff fue, entre los buenos poetas colombianos, el que abrió la marcha de la vanguardia"15. Según la visión historiográfica de Anderson Imbert, hay figuras enérgicas e iconoclastas que impulsan el surgimiento de la vanguardia con su personalidad poética y sus creaciones singulares, y De Greiff encarna esa figura en la literatura colombiana. Los "estallidos de ritmos, palabras y locuras" harían de su exuberancia lingüística la clave de su pertenencia al vanguardismo hispanoamericano, aunque una vez más su estética particular queda reducida a un impulso enteramente subjetivo, a una manifestación de "genio" que no da cabida a consideraciones estéticas, filosóficas y sociales de mayor alcance. En otra perspectiva, hay quienes relacionan la obra del poeta con las manifestaciones de una vanguardia expresionista latinoamericana, como es el caso del historiador alemán Rudolf Grossmann, quien asegura que en De Greiff "se pone de manifiesto con especial nitidez otro rasgo del expresionismo temprano: su polaridad de sencillez y preciosismo en una y la misma personalidad", componentes éstos que forman "parte de sus caprichos, como la

\footnotetext{
${ }^{15}$ Anderson Imbert 44. En una línea parecida, Darío Ruiz Gómez señala que "De Greiff pertenece a la generación de Vallejo, Neruda, Huidobro, Bandeira, esos que crean a través de sí una poética, un sentido existencial, una metafísica, esos que llenan de nombres un horizonte y en el padecimiento de este conflicto se consumen" (Ruiz Gómez 281). Asimismo, el autor, en referencia "necesaria" al culteranismo, ubica al poeta en la generación de Lezama, pero hace una diferencia entre el "barroquismo" de éste y la simple "pirotecnia" de De Greiff. En este punto, es necesario considerar las muchas interpretaciones de un mismo procedimiento, sobre todo en los estilos conflictivos propuestos por las vanguardias, pues si bien a veces esa "pirotecnia" sitúa al poeta en esa especie de azar de la palabra de una corriente como el dadaísmo, ello no significa que carezca de sentido ante lo que el autor llama "las más profundas características de nuestra naturaleza". En efecto, estamos ante una reflexión y experimentación sobre las multiformidades del lenguaje y la escritura, ese espacio complejo donde la literatura conforma, ni más ni menos, todas sus apreciaciones acerca de "nuestra naturaleza". Después se profundizará en este tema, incluso a través de referencias al "barroquismo", esta vez sí en De Greiff, por parte de Jaime Mejía Duque.
} 
acrobacia métrica que debía expresarse ya en los títulos de sus creaciones: Tergiversaciones (1925), Libro de signos (1930), Variaciones alrededor de nada (1936), Fárrago (1954)"16. Pese a la certeza de la alusión al lenguaje "caprichoso" en De Greiff -que sin embargo podría valorarse mejor si se lo considera en la dimensión referencial de sus procesos de significación, exuberantes pero coherentes con un objeto estético concreto-, las palabras de Grossmann producen la sensación de una homologación nominal no del todo precisa respecto del "expresionismo" al que se refiere, al emplear una denominación muy amplia y de numerosas implicaciones, que incluso en el continente europeo donde se originó no designaba un movimiento específico con un programa diferenciado, sino una tendencia heterogénea que vinculó elementos característicos de otras corrientes de vanguardia. En este punto, la precisión conceptual es necesaria y en todo caso demanda su correspondiente justificación, teniendo en cuenta la conformidad de los procesos artísticos latinoamericanos, principalmente, con sus propios procesos históricos, circunstancia que no olvida Rafael Gutiérrez Girardot cuando afirma que, en países como Colombia, la vanguardia no surgió como imitación automática de modelos extranjeros "bajo la influencia de las vanguardias europeas, de las que se tuvo conocimiento fragmentario y posterior, sino como el desarrollo dialéctico del modernismo literario y la modernización social" (Gutiérrez Girardot, Ensayos 82). El mismo Gutiérrez Girardot no duda en ubicar el inicio de la vanguardia en Colombia en el año de 1925, con la publicación de Tergiversaciones, primer "mamotreto" de nuestro poeta $^{17}$, y según paráfrasis de Charry Lara, "cuando la sociedad colombiana y su literatura

\footnotetext{
${ }^{16}$ R. Grossmann, Historia y problemas de la literatura hispanoamericana, citado en Charry Lara, Lector de poesía 84.

${ }^{17}$ Con respecto a esta denominación otorgada por De Greiff a cada uno de los poemarios que publicó en vida, Juan Manuel Cuartas se pregunta, con base en sus planteamientos sobre el procedimiento de la ironía en este poeta, "por qué llama 'mamotretos' a sus volúmenes de poemas; ¿con esa palabra que repele, que hiede a cosa vieja, grande, pesada, empolvada?; ¿qué podemos concluir de ello?: nada más ni nada menos que la teoría de la escritura de León de Greiff, la cual está hecha para decir apenas nada, para discurrir y desvariar, para crear una atmósfera con ráfagas de sentido que representen dramáticamente el Yo" (Cuartas, "León de Greiff" 120). O bien: "desde el lenguaje, origen de la ironía como lo hemos dicho, León de Greiff apunta más que a la designación e imaginación de las cosas, al agotamiento del poeta que proclama su Yo reducido y solitario. El 'mamotreto' es, a este respecto, paradójica y crucialmente, la 'tumba' de su escritura, como lo es del intelectual en términos generales: leer y atormentarse, cerrar el círculo del desasosiego con el libro entre las manos (entre las sienes)" (116). En la misma línea, Carmen Luna Sellés complementa: "Ante la consideración del libro como medio de transmisión de cultura; de garante de valores colectivos e individuales; de obra de arte terminada, León de Greiff, contraviniendo esta concepción institucionalizada, titula sus libros podríamos decir que de forma oximorónica: 'tergiversaciones', 'mamotretos', 'fárrago', 'velero paradójico', 'variaciones alrededor de nada', títulos donde el concepto que culturalmente poseemos del libro se encuentra semánticamente vinculado a su unidad contradictoria, que socava o destruye el significado de aquel. Hay en el empleo de esta estructura oximorónica, además de una caricaturesca mordacidad de su propio quehacer
} 
comenzaban a ponerse al día" (Charry Lara, "Los poetas" 649). Esta apreciación contradice la postura de autores como Harold Alvarado Tenorio, quien explícitamente califica este volumen de "modernista", y tiene a favor el argumento de que en sus páginas se puede encontrar figuras lingüísticas en absoluto comparables a ninguna manifestación del modernismo que le precedió, y en donde ya se evidencia el grado de innovación y experimentación que De Greiff introdujo en la poesía colombiana de la época, de cuño más bien tradicionalista. Por su parte, Jaime Mejía Duque pone en evidencia la ruptura entre el ambiente literario del país de la época y la nueva expresión desarrollada por De Greiff, con base en el quiebre histórico fundamental que representa la Primera Guerra Mundial en todos los ámbitos, y en particular en la poesía. Del "sistema de referencias a la vida diaria, al pasado histórico o mitológico y a los hechos más comunes de la sensibilidad amorosa, estética y religiosa", el poeta trasciende a otro nivel de inteligibilidad, con "saltos", "galimatías" e "incoherencia", en correspondencia a lo que sucedía con la vanguardia en Europa, donde "la primera guerra pisoteó la lógica formal que hacía parte de la idea de 'bello y lo sublime' a que Kant se había referido en términos accesibles para la mayoría semiletrada. Así considerado, León de Greiff es un vanguardista” (Mejía Duque 99-100). Es notable la distinción hecha entre la expresión del poeta y una tradición literaria colombiana que se prolongó, en realidad, mucho más allá de la primera guerra; aun así, se considera el vanguardismo excesivamente en virtud de sus referentes europeos, lo cual debe ser revalorado para profundizar más en el contexto social de Colombia y Latinoamérica, pues es necesario perfilar el medio literario concreto en que esta manifestación surgió, y así determinar con más eficacia su grado de novedad. Por último, y con base en el argumento de una ruptura con la tradición estética y política de Colombia, la crítica francesa Marie Estripeaut Bourjac califica no sólo a De Greiff sino a sus compañeros de Los Nuevos entre las generaciones vanguardistas de comienzos del siglo XX, por sus declaraciones explícitas contra la cultura señorial de la dirigencia política de entonces y de generaciones literarias como la del Centenario, así como por el imaginario que construyeron alrededor del mito de lo nuevo y del porvenir. En respuesta a la concepción del tiempo inmutable de esa cultura

literario, un deseo de que interpretemos la literatura como un quehacer libre, no sujeto a reglas, como conjunto de cosas o ideas desordenadas, inconexas o superfluas, sin valor institucionalizado, petrificado. Esta concepción, al margen de que acerque a León de Greiff a una inusitada postmodernidad, se aviene con la poética presente en muchos de sus poemas donde se proclama esa libertad por encima de conceptos institucionalizados sobre lo que debe ser la literatura" (275). 
señorial y a la protección del estatismo de su espacio vital, De Greiff en concreto, según la autora, opone sus ansias de inmensidad, de vagabundeo por los espacios ilimitados, en fin, de lo que Juan Manuel Cuartas entiende por “discurrir”. Con la reiteración de imágenes de lo efímero, se supera el tiempo inmutable en la atemporalidad de una "contemporaneidad eterna', y se efectúa así una transformación gracias a la cual nace el eterno instante”"18. Esta perspectiva de análisis permite una asociación directa entre De Greiff y las vanguardias europeas y latinoamericanas, al identificar, en el discurso mismo del poeta, los elementos que lo alejan definitivamente de las escuelas literarias precedentes y lo sitúan en una posición estética de avanzada, conquistada gracias a sus ideas sobre la incertidumbre de un pasado o de un futuro, sobre la errancia sin destino, sobre la necesidad de afirmarse a sí mismo en la novedad y la energía de la creación poética.

Desde una postura crítica más integral, existen autores que conciben la obra de De Greiff como una poesía de transición entre el modernismo y la vanguardia, al identificar en ella dos modalidades estilísticas con sus respectivos tonos, temáticas, estructuras e intenciones, que a veces corresponden a distintas etapas de creación del poeta y a veces se sintetizan en una misma expresión. La opinión de Fernando Charry Lara se inclina en esta dirección. Según él, muchos poemas en De Greiff son una prolongación del modernismo, en factores decisivos como el predominio de la sugerencia sobre la designación directa, la herencia del hastío de la existencia de Baudelaire y la insistencia en sus símbolos y correspondencias, el trabajo minucioso del artífice en su composición, la profusión de las alusiones culturales y su pasión por Laforgue, pero no como simple continuador de su "canción lunática", según la declaración de Maya, sino como partícipe "en su mueca de disgusto e ironía" (Charry Lara, "Los poetas” 661). Por otra parte, si bien la poesía en De Greiff es “devota del ideal simbolista" y "su voz se emparenta mejor y se la escucha más acorde con los poemas modernistas" (661), el autor no deja de reconocer, junto con Anderson Imbert, que fue él quien inició "la marcha de la vanguardia" en Colombia, a partir de sus lecturas de Alfred Jarry, Gillaume Apollinaire y Max Jacob, por compartir el “común ademán sedicioso” que caracteriza a las vanguardias y exhibir un "extremo subjetivismo" que hace de su poesía "una obra, más que original, casi única. Por eso es tan suya su atmósfera de sueños,

\footnotetext{
${ }^{18}$ Estripeaut Bourjac 748. El concepto de "contemporaneidad eterna" es de Vladimir Jankélévitch.
} 
melancolías, nostalgias, deseos de expresar lo inexpresable, lo inadvertido, lo inefable. Por ello también la exclusividad de su lenguaje" (667). Así pues, la percepción de Charry Lara sobre esta obra parece ser la de una poesía vanguardista dentro de su modernismo, en virtud de una originalidad sin precedentes e imposible de catalogar según modelos anteriores; se trata de una poesía modernista que rompe con los moldes del modernismo, una poesía tan única en su vanguardismo que no se asemeja a movimiento vanguardista alguno. En cuanto al crítico cubano Orlando Rodríguez Sardiñas, en sus estudios sobre De Greiff, exhaustivos y con multitud de enfoques, se destacan los que abordan eso que él llama "motivaciones temáticas" de su poesía, cuya denominación incluye temas generales, asuntos recurrentes y motivaciones poéticas (según la clasificación conceptual establecida por el teórico literario Wolfgang Kayser), así como otros donde analiza el origen y la naturaleza de sus imágenes y símbolos poéticos, derivando de cada elemento su especificidad respecto a las inquietudes del poeta y a las estéticas del modernismo y la vanguardia, las cuales influyen, cada una a su manera, en aspectos concretos de su obra. Para el autor, De Greiff participa, de modo permanente y en gran medida, de temáticas de inspiración modernista, como la afirmación de un individualismo estético en un mundo caracterizado por su prosaísmo y su vulgaridad, la presencia constante de la noche "lunática" íntimamente ligada a los ensueños del poeta, o el retorno incesante de figuras de la historia, el arte y la mitología, todo ello en un escenario sobrecargado de sinestesias y policromías (Rodríguez Sardiñas, "Motivaciones temáticas" 42). No obstante, entre estos elementos se desencadenan fuerzas que trascienden la estética finisecular de la escuela presidida por Rubén Darío, como el empeño en la construcción poética y sistemática de un universo lejano y opuesto a nuestra realidad convencional -en un ademán cercano al creacionismo, pero muy particular, muy suyo, como, por otra parte, todo lo demás-, con sus propias leyes, su geografía y sus personajes, en donde "los planos de lo real y de lo imaginario se entrecruzan", merced a una "actitud de Hacedor", propia de una "especie de dios que dice venir de un imperio ultraterreno maravilloso de eterna primavera" (Rodríguez Sardiñas, "León de Greiff" 210). Se trata de un universo habitado por multitud de seres y objetos con respectivos oficios, atributos y personalidades, aunque polifacéticos en su ironía, su máscara y su heteronimia, todos ellos envueltos en imágenes sonoras que superan, desde todo punto de vista, el anhelo simbolista del vínculo entre la música y la poesía, con una musicalidad omnipresente y materializada en cada componente 
de ese universo poético, considerada así "la marca del pecado original de las criaturas greiffianas" $"$. En consecuencia, la transición entre el modernismo y la vanguardia se produce, según el autor, en la síntesis operada por De Greiff entre una poesía de inspiración modernista y ráfagas muy personales de una estética de avanzada, provenientes de una personalidad poética individualista y en grado sumo innovadora, que remueve los moldes establecidos sin, no obstante, llegar a destruirlos o modificarlos del todo ${ }^{20}$. En una postura mucho menos exhaustiva, pero también en esta línea "transicionalista", Hugo Verani se ha limitado a afirmar que "León de Greiff, poeta de transición y simbolista, insinúa una libre inventiva de vanguardia, pero conserva formas tradicionales, fáciles y decorativas consonancias" (Verani 20). El diagnóstico es breve, terminante: "En Colombia, país tradicionalista y cauto, aferrado a un modernismo epigonal, las proyecciones del vanguardismo han alcanzado escaso desarrollo; no hubo actividad de verdadera vanguardia, sólo figuras aisladas que acogen tendencias innovadoras y antirretóricas” (19). Según parece, De Greiff es una de esas “figuras aisladas" favorecidas por la radical sentencia del crítico uruguayo. Con todo, desde su óptica, estas figuras descollantes no llegan a ser tales en el acto de crear, sino sólo en el de "acoger". El mayor mérito de su juicio reside, no obstante, en que apunta de manera esquemática, aunque parcializada de antemano, a una

\footnotetext{
${ }^{19}$ Rodríguez Sardiñas, "León de Greiff” 211. La asociación del poeta con el creacionismo ha sido compartida por varios autores. Eduardo Gómez, respecto de la invención de multitudes a partir de una concepción amplia del lenguaje y de lo musical, menciona que, en De Greiff, "el torrente incontenible de palabras (inventadas muchas de ellas combinando diversas raíces, a veces de idiomas extranjeros, o por medio de alusiones sutiles a personajes literarios, hechos históricos o ficticios) se torna paroxístico y casi desesperado en su intensidad musical delirante y en su creacionismo desbordado" (Gómez 165). La crítica española María Caballero, asimismo, vincula la "experiencia física de la palabra" en su poesía "con las teorías creacionistas del Non Serviam de Huidobro. La riqueza y variedad de su léxico, y los incesantes juegos de palabras en pro de la experimentación lingüística, le acercan a la destrucción del lenguaje de Altazor" (Caballero 83).

${ }^{20}$ Aquí cabe anotar, sin embargo, que para algunos autores el modernismo hispanoamericano es mucho más que un simple conjunto de conceptos y prácticas literarias ubicable, sin mayor problema, en los años próximos al cambio de siglo; se trataría, por el contrario, de una manifestación de gran alcance que prolongó su influencia hasta el corazón mismo de las vanguardias, pero no precisamente como el germen de la "anarquía moral y estética" de éstas (Jiménez Panesso, Historia de la crítica 171), según la interpretación superficial y dogmática de Rafael Maya, sino en el sentido que le adjudica Federico de Onís, como "la forma hispánica de la crisis universal de las letras y del espíritu que inicia hacia 1885 la disolución del siglo XIX y que se había manifestado en el arte, la ciencia, la religión, la política y gradualmente en los demás aspectos de la vida entera, con todos los caracteres, por tanto, de un hondo cambio histórico, cuyo proceso continúa hoy" (F. de Onís, citado en Charry Lara, "Los poetas" 634). De acuerdo con esta tesis, todos los poetas y escritores hispanoamericanos que a comienzos del siglo XX profesaron una estética de avanzada, comparten un mismo origen en el movimiento modernista, pero participan de una doble naturaleza en virtud de sus innovaciones más audaces respecto de lo más tradicional de este movimiento. En suma, la catalogación de De Greiff como poeta vanguardista sería correcta, a causa de su evidente lejanía estética de figuras como la de Rubén Darío o la de Guillermo Valencia, y a un mismo tiempo se justificaría su análisis bajo la perspectiva del modernismo, a cuyo espíritu se remonta su inspiración.
} 
verdad incuestionable: la adopción por parte de la cultura oficial de un modernismo caduco y conservador encarnado por Guillermo Valencia -no ciertamente de aquél que representa para Federico de Onís la expresión de la crisis y la disolución del siglo XIX-, en contraposición a la individualidad aislada de quienes, como De Greiff, introdujeron en la poesía colombiana un aire de contemporaneidad, la audacia de una actitud estética cuando menos desestabilizadora de la tradición poética. Por su parte, Harold Alvarado Tenorio comparte la tesis de la transición, desde un argumento que vincula lo estético con lo cronológico, al afirmar que "Tergiversaciones [primer "mamotreto" del poeta] es un volumen que puede calificarse como Modernista", mientras que en Libro de signos, Variaciones alrededor de nada y Prosas de Gaspar -"mamotretos" segundo, tercero y cuarto, respectivamente-, "De Greiff se apropiará de todas las conquistas de los Ismos pero sin tomar partido por ninguno de ellos. Será unas veces dadaísta, otras surrealista, otras anarquista y la mayor de las veces un creacionista, que desdeñando la realidad, o lo que por ello entendemos, prefiere crear otra realidad que interprete a aquélla o nos aparte definitivamente del presente - ¿Modernista?- que tanto repudia el poeta" (Alvarado Tenorio 388). El inciso problemático de este enunciado a favor de su vanguardia (“¿Modernista?”) representa, por lo demás, la dificultad de clasificar con toda propiedad una obra que oscila permanentemente entre las dos márgenes de lo que parece ser un mismo sendero poético, ese sendero personalísimo del poeta, cuya voz, que habría de identificarlo "en el concierto de la poesía continental", se nutre de "burla e ironía, olvidadas sintaxis, palabras envejecidas, neologismos y arcaísmos, atado todo ello con un rigor musical muy suyo" (Alvarado Tenorio 388), aspectos presentes, ahora sí, en la totalidad de su producción lírica, sin distinción alguna de títulos o cronologías. Algo más acertado parece ser el juicio de quienes evitan la inamovilidad de las clasificaciones -incluso respecto de un volumen $\mathrm{u}$ otro en particular-, y optan por identificar en toda esta poesía múltiples concepciones y estilos no asociables con un solo movimiento literario. De este parecer es la crítica española Carmen Luna Sellés, quien desconfía de la denominación "vanguardista" aplicada sin gran rigor estético o de manera demasiado rígida, y afirma en consecuencia que De Greiff se desliza "entre diversos 'ismos', aceptándolos en ocasiones, parodiándolos en otras" (Luna Sellés 272), con lo cual se hace imposible su homologación a uno en particular. De hecho, para la autora, ese "deslizamiento" termina siendo el más auténtico de sus elementos de 
avanzada, pues “de esa contradicción y de su puesta en práctica desafiante surge la originalidad de este poeta; originalidad que le vincula con la vanguardia" (281). Se acepta la condición de vanguardia, pero sólo en su conflicto dialéctico con el modernismo en que se inspira:

Es la suya una obra singular y original que irrumpe en el momento histórico de las vanguardias dialogando, aceptando, difiriendo, deslindándose del modernismo hispanoamericano y de los autores románticos y simbolistas que fueron para él señeros; deslinde poético, que se suma a una pose pública desafiante ante la pacata sociedad en la que vivía, que lo acerca a la vanguardia. (273)

Aquí es interesante considerar la problematicidad de la denominación de "vanguardista" a partir de lo que la autora nos sugiere, pues ante todo debe definirse qué se comprende como tal. El planteamiento es claro y sencillo:

Desde que Guillermo de Torre (1965) en su Historia de las literaturas de vanguardia y Anderson Imbert (1961) en Historia de la literatura hispanoamericana le aplicaron de forma excesivamente rígida el marbete de vanguardista, este siguió siendo utilizado durante mucho tiempo de forma mecánica, sin ninguna atenta y crítica mirada de su compleja obra. En la actualidad se ha tratado de subsanar esta falta de rigor crítico valorando la especial originalidad y ruptura de su poesía en función del sistema literario en el que el autor estaba inserto y no tanto en función de los parámetros trazados por las vanguardias históricas". (267-268)

Esta precisión es sumamente importante, pues remite a la indefinición alrededor de lo que se debe entender por "vanguardia" en nuestro continente: o una serie de movimientos de revaluación de la tradición artística anterior al siglo XX en Latinoamérica, o simples adecuaciones estilísticas a programas de movimientos europeos. No es necesario rechazar de plano la denominación, pero hay que dotarla de un sentido más auténtico que responda en verdad a las condiciones de los artistas latinoamericanos, indisolubles de un contexto social y estético propio, no homologable sin reparo alguno con otras tradiciones. Por último, la aproximación del crítico venezolano Miguel Gomes también llama la atención sobre algunos tópicos críticos acerca del poeta, principalmente los relacionados con su inclusión indiscriminada en la vanguardia, que conviene tener en cuenta para evitar imprecisiones o generalizaciones equivocadas en torno a una poesía que, como dice Charry 
Lara, "implica el vencimiento de más de un obstáculo" (Charry Lara, "Los poetas" 663). Gomes, acudiendo al teórico literario Franco Moretti, insiste en retomar conceptos como la "discontinuidad" en un campo literario donde "fuerzas de equilibrio y desequilibrio son incesantes" (Gomes 421). Esta modificación de parámetros debería incidir favorablemente en la comprensión de un poeta cuyo estudio, siempre fragmentario, ha suscitado polémicas recurrentes que no han sido resueltas:

La poesía de León de Greiff ha sido sometida, hasta ahora, a las casillas de los "ismos" sin atender a la naturaleza movediza de éstos y sin considerar que los movimientos, más que un límite o un espacio intelectual cerrado, son puntos de referencia colectivos para discursos individuales que tienen la posibilidad de acatarlos, pero también de ampliarlos, modularlos e, incluso, infringirlos. (422)

Si bien la clasificación unilateral de De Greiff en el modernismo es problemática, también lo es su identificación absoluta con el vanguardismo, pues su estética se compone de multitud de elementos que, como afirma Luna Sellés, se deslizan entre prácticamente todos los movimientos de su época. Así, la unilateralidad respecto a una obra que de ningún modo la admite, sólo genera falsos criterios en torno a los elementos que no se avienen con ella: "La poética del autor desde sus primeras obras hasta las últimas tiene una veta modernista importante, que impediría su clasificación rotunda o excluyente como "vanguardista"" (Gomes 432). Es claro que, para hablar de vanguardia en De Greiff, es preciso delimitar con claridad qué aspectos de su obra o su poética pretenden considerarse tal, y trabajar en su análisis con cuidado de no desdibujar desde allí los aspectos que no corresponden del todo a esa tendencia. De nuevo, una resignificación de la vanguardia en nuestro continente es necesaria para no prolongar la indefinición en torno a los autores con que suele asociarse, y así poder comprender mejor las propiedades de éstos en particular y la evolución de las letras latinoamericanas en general, no necesariamente lineal sino “discontinua”, esto es, con puntos de fuga en diversas direcciones estéticas y temporales.

Otros autores optan por enfocar su análisis desde posiciones críticas menos influenciadas por clasificaciones de tendencias o escuelas determinadas, en favor de un estudio que pueda regirse a partir de las especificidades de la obra del poeta. Con ello, toman distancia de una polémica muchas veces infructuosa que durante décadas ha vacilado entre dos polos no 
suficientes, de modo unilateral, para definir y caracterizar la totalidad de la obra de De Greiff. En primer lugar, se puede mencionar un autor de reconocida influencia intelectual ya en tiempos de las primeras publicaciones de De Greiff, el crítico colombiano Baldomero Sanín Cano, quien refería en los tempranos años treinta la amplitud del proyecto estético del poeta desde el poder del discurso como espacio de conjugación de múltiples elementos de la cultura:

De Greiff es "el poeta". Toda su vida, toda su inteligencia, todos sus estudios miran a la poesía. Adora la música por las relaciones indestructibles que median entre este arte purísimo y su hermana menor la poesía. Se ha absorbido todas las leyendas mitológicas del oriente y del norte para enriquecer su caudal de imágenes y para ensanchar sus gustos. Anda por los vocabularios de términos anticuados en busca de palabras cuyas formas y sentidos primitivos se hallen más cerca de los conceptos prístinos de que hace su tesoro el poeta. Saquea los idiomas modernos en el anhelo de buscar voces más precisas, más adecuadas a la emoción del momento". (Sanín Cano 260)

El crítico señala además que la poesía de De Greiff “delata el estado de alma dionisíaco. Hay una exuberancia vital en las formas de expresión, en el cúmulo y la variedad de las imágenes, en el vigor representativo de las comparaciones" (261). La instancia estética se revela, entonces, como un factor prioritario a través de cuya lente se asimila la totalidad de la cultura en un gesto enérgico de alcance universal. Por desgracia, Sanín Cano no se involucró en un análisis sistemático de la obra de De Greiff -ni de poeta o escritor alguno, por cierto, lo cual habría sido provechoso, teniendo en cuenta el buen sentido crítico que lo caracterizaba-, y sus apreciaciones se limitaron a esbozar en líneas muy generales algunas de las principales inquietudes del poeta, a manera de reseña antológica o nota periodística, aunque ubicando con precisión el nudo donde convergen las claves estéticas de una escritura hasta entonces poco comentada y desprovista en su conjunto de antecedentes significativos que facilitaran su comprensión. Por otro lado, está Andrés Holguín, quien opina que el poeta “abre la poesía colombiana contemporánea”, en virtud de "su prodigioso sentido musical, su fina ironía -dirigida ante todo contra sí mismo-, su humorismo soterrado, sonriente, su amargo pero contenido dejo íntimo, y, sobre todo, esa su voz inconfundible, que ha inventado un vocabulario propio para expresarse con una pasmosa riqueza idiomática" (Holguín 152). Su tesis sobre la "voz inconfundible" del poeta la refuerza Holguín al asegurar que "su voz no es nunca un eco. Es el instrumento 
desconcertante de su autobiografía", o bien, "una prolongada, inacabable confesión" (153). Se configura así un universo laberíntico que es preciso explorar de manera exhaustiva para comprender las claves de esta poesía, de donde se deduce la cualidad muchas veces accesoria de denominaciones externas a ella misma, y la necesidad de abordarla desde los componentes internos que constituyen su esencia ${ }^{21}$. Por otro lado, el análisis del crítico español Benjamín Mantecón Ramírez involucra el tema del amor en la poesía de De Greiff, que en la opinión de muchos comentaristas constituye, junto al 'Yo' del poeta, uno de los temas principales de su obra. El estudio se centra en las concepciones del amor, entendido como pasión, como ideal y como conjunción con la noche y la muerte, con la salvedad de que sus apreciaciones parecen efectuar, más que literalmente, la identificación entre vida y obra en De Greiff establecida por Holguín, pero que este autor aborda, cabe aclarar, desde el ámbito exclusivo de lo expresado por la poesía. De tal manera, el crítico trasciende en ocasiones el plano estético, prolongando sus juicios a la propia persona del poeta y privándolos, por ello, de validez estética, como al afirmar que "desde los comienzos de su obra -juventud del poeta- hasta sus últimas composiciones -vejez-, se manifiesta de un modo claro y patente su apetencia sexual” (Mantecón Ramírez 426). En resumen, el estudio parece ser más una descripción de elementos asociados a la idea del amor en la persona del poeta, que un análisis sobre sus relaciones intrínsecas a la obra misma, cuyo mérito más evidente consiste en descomponer y clasificar los factores del discurso amoroso en De Greiff y recurrir para ello a un amplio repertorio de versos. Por su parte, el estudio de Juan Manuel Cuartas se detiene más específicamente en la instancia de la escritura, al abordar la obra del poeta desde la idea del 'Yo' y las formas en que éste se manifiesta, la mayoría de los casos a través del procedimiento de la ironía. Aquí se observa una de las problemáticas fundamentales en De Greiff: la oscilación entre la individualidad del poeta, sumamente propia y original, y el desgarramiento de esa individualidad a partir del recurso de la ironía. La individualidad del poeta es evidente y explícita en una obra que se nutre de su personalidad enérgica y entregada por completo a la poesía, como coinciden en señalar

\footnotetext{
${ }^{21}$ Germán Espinosa comparte esta convicción sobre el carácter eminentemente personal del poeta, más allá de su clasificación en un estilo preestablecido, al asegurar que "resulta imposible delimitarlo en el ámbito de las escuelas, viejas o modernas". De modo explícito, rechaza el concepto de vanguardia para su obra en conjunto, al señalar que "si bien a partir de él la poesía colombiana (y acaso la de Hispanoamérica) experimentó una renovación o, mejor, una revitalización de amplia gama, lo cierto es que no se trata de un 'vanguardista', en el sentido usual de la palabra, sino de un poeta de síntesis, capaz de expresarse a través de las audacias más de avant-garde o de las formas poéticas más remotas, sin dejar nunca de ser él mismo" (Espinosa 167).
} 
muchos autores; pero se manifiesta con la apariencia de una disyuntiva que incide en la ampliación de los dominios y los alcances de su universo poético, donde todo se conjuga bajo el signo del juego y la contradicción:

La ironía se formula cuando se considera que el sujeto participa tanto de la convicción idealista, a la que ha llegado de manera poco crítica, como del interés material; podemos acceder en este sentido a un concepto de la ironía en León de Greiff según el cual la ironía descompone el Yo en la obra, es su discontinuidad y su escritura al mismo tiempo. La ironía arredra la individuación del autor en la escritura, representando al mismo tiempo tanto su humanismo inalterable como su aprisionamiento en las redes del tedio y la melancolía. Como la figura nietzscheana del dios despedazado cuya doble naturaleza representa un sátiro salvaje y cruel, desdoblado en un soberano dulce y clemente, de igual manera nos representamos al León de Greiff creador de poemas profundamente inmerso en la tragedia continuada de su ironía, su vida y su arte. (Cuartas, “León de Greiff” 114)

El análisis de Cuartas evidencia una de las claves de la poesía en De Greiff, la afirmación constante y radical de una individualidad que no puede concebirse a sí misma sino en su relación contradictoria con la totalidad de la existencia. Esa serie de relaciones múltiples y conflictivas es la que se manifiesta por medio de la ironía. El autor trasciende también la concepción tradicional sobre el elemento dionisíaco en la poesía de De Greiff, normalmente asociado a la bohemia, el licor y el amor pasional, y amplía la dimensión de esa exaltación al acto de nombrar, un "delirio" que pretende "abarcar el universo con la palabra; una ensoñación semejante al juego de un niño solitario que ocupa la realidad muerta de sus juguetes con sus palabras"22, afirmándose así en la línea de Sanín Cano ya referida. En suma, la individualidad omnipotente, aunque disyuntivada, se lanza a la comprensión simbólica del universo mediante el "discurrir" de un juego sin finalidad aparente, cuyo signo es la ironía y la contradicción. El crítico comprende bien la exuberancia verbal del poeta en relación con su deseo de "abarcar el universo con la palabra", en relación con el “delirio de nombrar en la poesía de León de Greiff [...], un gusto por la abundancia sonora

\footnotetext{
${ }^{22}$ Cuartas, "León de Greiff" 120. El juego con la palabra es constante en De Greiff y alude en más de un sentido a una actitud de vanguardia que revalúa y trastoca lo tradicional, que asume el lenguaje poético como espacio lúdico y revitalizante. Respecto a esto, lo que Lino Gil Jaramillo llama "posesión y goce del idioma" en De Greiff (Gil Jaramillo 414), es esa misma actitud a que hace referencia el poeta cubano Nicolás Guillén: "León de Greiff es un obsedido por la palabra inusitada, de consonante difícil, y gusta por ello de ir planteándose en el curso de la composición problemas de técnica por el placer de resolverlos, como un inagotable prestidigitador" (Guillén 11).
} 
que no queda atrapada simplemente en los mecanismos de la rima en la búsqueda ineluctable de homofonías y acentos" ${ }^{23}$. El estudio de Cuartas es esclarecedor respecto de ciertos tópicos de la obra de De Greiff que no han sido abordados con el detenimiento necesario y la profundidad adecuada; sus concepciones sobre el individualismo del poeta, el procedimiento de la ironía, sus relaciones contradictorias con el universo de significaciones que pretende abarcar, la abundancia delirante de su lenguaje o el factor lúdico implícito en la composición de sus textos, son puntos de referencia fundamentales en el análisis de una poesía individualista y múltiple por definición, propia y universal, como se refirió a ella Juan Gustavo Cobo Borda (63). No obstante, el crítico desemboca en una "encrucijada" que le impide establecer una relación entre la obra de De Greiff y los fenómenos sociales -arte, historia, pensamiento, etc.- de los cuales forma parte indisoluble, al señalar en ella una autorreferencialidad ensimismada:

La entrada en la encrucijada del Yo que realiza De Greiff opera, de otro lado, una suerte de descontextualización con la realidad; poesía que tiende hacia dentro de su lenguaje, substrayéndose a la percepción crítica de la realidad conflictiva colombiana o latinoamericana que le tocó vivir al poeta. Efectivamente, en su poesía hay una intención definitoria de la vida, no de la época: dejar claro que en la letra y en la paradoja de la letra que la vida ha sido vana [sic], que el tiempo ha sido inútil, que de tanto decir "palabras sin sentido conocido" se han vuelto las razones amargamente contra el Yo, y se ha disuelto todo en un ineficaz ensueño. (Cuartas, “León de Greiff” 133)

Las relaciones de diálogo u oposición entre el arte y la sociedad no provienen de la mención explícita de ésta en el discurso estético, sino que han de buscarse en la instancia misma de la configuración de la obra, como lo han señalado Theodor Adorno, desde la teoría crítica, o Roland Barthes, desde el estructuralismo y el posestructuralismo, y es esto lo que ignora la tesis de Cuartas sobre la "encrucijada del Yo" y la "descontextualización con la realidad". Es improcedente la idea de una "descontextualización" en una totalidad

\footnotetext{
${ }^{23}$ Cuartas, "León de Greiff" 120. En efecto, el autor encuentra otra clave fundamental de la escritura en De Greiff, al asociarla con el acto de "discurrir, divagar, desvariar, disparatar, delirar, decir despropósitos, hablar sin concierto; ¿es éste acaso el raro motor de la poesía de León de Greiff?; una primera impresión responde $S i$ a la pregunta; el lenguaje redundante y contundente lo concede así mismo"; y con base en este planteamiento anuncia "nada más ni nada menos que la teoría de la escritura de León de Greiff, la cual está hecha para decir apenas nada, para discurrir y desvariar, para crear una atmósfera con ráfagas de sentido que representen dramáticamente el Yo" (Cuartas, "León de Greiff" 120; las cursivas son del texto). V. pág. 21, nota 17, del presente trabajo.
} 
que no admite la posibilidad última del aislamiento, y desde Adorno es evidente que toda obra de arte participa de la realidad social y la problematiza a través de la negatividad de la experiencia estética. La poesía en De Greiff no se sustrae a la realidad conflictiva "que le tocó vivir al poeta", por la sencilla razón de que le es imposible hacerlo. En su estética se problematiza la idea del sujeto como presupuesto fundamental de la sociedad burguesa y de la tradición de la modernidad, así como el conflicto del artista en medio de una realidad desestabilizada que lo ha despojado de su posición de preeminencia social. Es el mismo conflicto de una sociedad crecientemente secularizada, en términos de Gutiérrez Girardot, que ha cuestionado y revalorado sus ídolos, sus mitos y sus jerarquías; un conflicto derivado de eso que Jean-François Lyotard define como condición de existencia del capitalismo, la "evasión de la realidad fuera de las seguridades metafísicas, religiosas, políticas, que la mente creía guardar a propósito de sí misma” (Lyotard 19-20). La poesía es una construcción social que no puede ser concebida como una manifestación ajena, en sus formas, dinámicas y problemáticas, a la realidad social de la cual forma parte, y la poesía en De Greiff no es, ni mucho menos, una excepción a este respecto. Su crítica de la idea del sujeto en un contexto de pérdida de seguridades "que la mente creía guardar a propósito de sí misma" es la prueba. El empleo de categorías estéticas más amplias quizá contribuya, en este sentido, a identificar las conexiones precisas que esta poesía establece con los demás ámbitos de la sociedad, desde una perspectiva integral que no ignore deliberadamente las herramientas teóricas y conceptuales disponibles para ese fin.

El corpus analítico así presentado pone en evidencia problemas ineludibles en un estudio sobre la poesía de De Greiff desde cualquier postura teórica o crítica que se adopte, como la configuración del 'Yo' del poeta en su relación con el universo poético en que se despliega, la abundancia exuberante de su lenguaje y su disgregación en múltiples personalidades poéticas; se evidencia también, en no pocas oportunidades, la carencia teórica de algunos estudios que sin embargo acuden a un amplio repertorio de estos tópicos, con el fin de suplir el reducido alcance de sus hipótesis y perspectivas; y se presentan finalmente, aunque en menor medida, ocasiones en que se profundiza, con base en una intención y un plan de trabajo sólidos, en aspectos claves del objeto de análisis, rehusando las descripciones más convencionales y abordando problemas fundamentales desde un panorama conceptual de 
mayor alcance. En síntesis, la obra de De Greiff se presenta a nosotros, a través de las décadas y los muchos autores que la han estudiado, como una singularidad imposible de catalogar totalmente en una corriente estética específica; una obra que constituye el inicio de una nueva era en la poesía colombiana -hasta entonces demasiado respetuosa de los cánones formales más conservadores y de las concepciones poéticas más tradicionales, con la excepción de pocas figuras sobresalientes, como José Asunción Silva-, y que se nutre de una multitud de referentes culturales en un entramado simbólico laberíntico que reproduce la imagen caleidoscópica del autor, la cual ha de proporcionarnos, desde su singularidad, las claves para su interpretación. No obstante esta caracterización manifiesta e indudable, es preciso ampliar la perspectiva del análisis y estudiar la obra en relación con las tendencias más universales del arte, de la historia y del pensamiento de la época, que sean pertinentes para dilucidar con mayor precisión las particularidades constitutivas de su singularidad y descubrir en sus propias leyes las condiciones en las que establece ese diálogo.

En las últimas décadas el análisis de la obra de De Greiff, pese al diagnóstico de Charry Lara sobre su insuficiencia para contribuir a su mejor comprensión ${ }^{24}$, ha mostrado avances muy significativos en lo que a rigor conceptual y de método se refiere, conforme a una tradición crítica que ya no acepta la evidencia compartida como única fuente, e indaga de nuevo en estos problemas desde una base epistemológica mucho más sólida. Estudios de autores como Rodríguez Sardiñas, Cuartas o Estripeaut Bourjac son esclarecedores en este sentido; sus análisis demuestran seguridad y practican una concepción distinta frente a la crítica de esta figura tradicional de la literatura colombiana. Es necesario avanzar en esta

\footnotetext{
${ }^{24}$ En efecto, Charry Lara señala: "En muchos años apenas avanzó unas líneas la crítica sobre la poesía de De Greiff, en relación con la que recibió en sus primeros volúmenes: Tergiversaciones (1925) y Libro de signos (1930). Aún hoy es notorio el desconocimiento de ella. Se han escrito numerosos artículos periodísticos que de todas maneras no pretenden rebasar la simple anécdota, el elogio más entusiasta que razonado o, aunque con el tiempo fuesen cada vez más raros, la acometida velada o sin ambages. Se han preparado asimismo, en medios universitarios, estudios más consecuentes, en especial en el campo estilístico, entre los que merece nombrarse, aparte del ya referido del señor Mohler, el del profesor cubano Orlando Rodríguez Sardiñas intitulado Una poética de vanguardia. Tales trabajos, y algunos pocos más de intención esclarecedora, deberían haber contribuido a una mejor comprensión de esta obra. Pero lo cierto es que infortunadamente ello no ha sido así". Esto es parcialmente cierto, ya que los trabajos sobre bases teóricas más sólidas existen, pero no han recibido la difusión que se merecen en los círculos académicos ni más allá de ellos. En cambio, no hay duda de lo que el autor afirma al cierre del comentario: "Su predominante emoción mental, sus alusiones a la intimidad de su propia vida, su riqueza de lenguaje y de ritmos, su perseguida estructura musical, su funámbula pirueta sonora, sus referencias culturales, su indiscutible y minuciosa construcción retórica, en suma, son calidades de la obra de León de Greiff que seguirán sustentando la creencia común de que la lectura suya implica el vencimiento de más de un obstáculo" (Charry Lara, "Los poetas" 662-663).
} 
línea desde posiciones teóricas aún más amplias y diversas, para contribuir con ello a la comprensión de una obra que sólo después de muchos años de ser concebida, acogida e incluso reverenciada, pero al mismo tiempo muy parcialmente conocida e interpretada, ha comenzado a manifestar, desde su propia estructura, las claves de un proceso de enorme significación, no sólo para la poesía colombiana sino para toda la poesía hispanoamericana: el advenimiento de una modernidad con nuevas concepciones del individuo y la sociedad, y el cambio del papel del artista en esa sociedad, incorporado como entidad dependiente en la búsqueda de su individualidad simbólica, como producto irónico de una afirmación estética mediada por lo social, de una autosuficiencia que no es tal en la medida en que lo uno se disgrega en lo múltiple, lo propio en lo universal ${ }^{25}$.

En el presente trabajo se adoptará una perspectiva enfocada en la estética de vanguardia del poeta, con base en el elemento concreto del descentramiento del sujeto a partir de la ironía contra la poesía y el poeta mismo, la divagación en el discurso y la fragmentación de la subjetividad; pero en ningún caso se pretenderá que es la única perspectiva correcta para aproximarse a una obra tan multiforme, evitando así caer en uno de tantos unilateralismos que han impedido formarse una visión amplia de la obra del poeta. Se intenta así analizar esta poesía en el marco de los avances característicos de los movimientos de vanguardia de principios del siglo $\mathrm{XX}$, pero desde sus particularidades respecto al contexto colombiano e hispanoamericano de la época, desde donde se puede comprobar o no su condición de avanzada. El estudio se enfoca en uno de los muchos perfiles que proyecta esta obra, cuyo carácter de vanguardia se intenta corroborar, sin por ello negar, en ningún momento, la existencia de otros elementos menos avanzados que a veces se asocian con la poética finisecular: este perfil es el distanciamiento de una tradición literaria moderna, fundada en la idea de la univocidad del sujeto y su configuración estable en el discurso.

\footnotetext{
${ }^{25}$ La ampliación de los marcos analíticos es un imperativo respecto a los estudios sobre De Greiff, después de décadas de análisis impresionistas desde posiciones enteramente inocuas y demasiado enfocadas al relato de anécdotas de su vida, la enumeración de sus influencias literarias y su grado de pertenencia a corrientes modernistas o vanguardistas con argumentos estereotipados sobre estos movimientos, y manifiestos errores o imprecisiones de método. Es correcta la apreciación de García Maffla, cuando asegura que "ningún autor de versos suscitó tantas adhesiones -y reacciones- como él, ninguna obra fue al final más admirada, ninguna imagen personal más querida $\mathrm{y}$, no obstante, puede afirmarse que, como la suya, ninguna poesía en cuanto obra de conjunto fue y ha sido menos leída" (J. García Maffla, "León de Greiff", citado en Cuartas, "León de Greiff" 111).
} 
Podemos asimilar las contradicciones críticas ya examinadas en los antecedentes como efectos naturales de una obra a su vez contradictoria. No podía ser de otra manera. El poeta plantea muchos retos, y quizá sólo después de clausurar una tradición crítica demasiado anclada en sus elementos modernistas sea posible comprobar que éstos no son suficientes, en absoluto, para comprender muchos otros elementos de carácter más contemporáneo. En cierto modo, todas las interpretaciones han sido correctas, pero sólo en relación con la faceta específica que cada intérprete ha seleccionado entre las múltiples facetas posibles ${ }^{26}$. El error está la segmentación excesiva y muchas veces no consciente del objeto de estudio, en virtud de lo cual se llega a considerar generales atributos que sólo son parciales. La métrica clásica y el lenguaje castizo forman parte del repertorio del poeta, es cierto, pero también las audacias vanguardistas o las estructuras musicales sin precedentes. Su concepción de la poesía no pertenece al ámbito de una sola escuela, sino que se nutre de

\footnotetext{
${ }^{26}$ En un texto pionero respecto a la desintegración de subjetividades en el poeta, Luis Vidales, su compañero de vanguardia en Los Nuevos, convencido de que no existe un solo De Greiff, sino nueve ("Nueve poetas en uno. El polifacético León de Greiff"), alude al reto planteado por su carácter contradictorio, aunque referido más en particular a aspectos de su biografía, del siguiente modo: "Así se explica el contraste que se establece en la poesía de León con su posición personal ante los acontecimientos del mundo de hoy. La gente suele preguntarse cómo un poeta que sólo se canta a sí mismo puede negar esta condición de exclusividad de los demás, colocándose al lado de determinada orientación en las grandes contiendas de nuestro tiempo. ¿Cómo puede señalar con desdén a 'la plebe' en algunos de sus cantos y estar a su lado, ostensiblemente, en la dirección de organismos políticos de expresión popular y revolucionaria? ¿Cómo alude un día, dentro de la diametración despectiva de su filosofía, a Lenin, por ejemplo, al paso que en otro poema lo exalta? ¿Cómo rezuma aristocratismo en la médula de sus cantos, siendo así que su adhesión a la causa diametralmente contraria le gana los más manifiestos sufragios, tales como el de su declaración en una entrevista televisada: 'Desde 1917 soy amigo de la URSS y me importa un carajo lo que se diga de mí'? Pues bien, se trata no de una contradicción, sino de la más agresiva consecuencia de su temperamento. [...] Uno de esos seres era León de Greiff. La esquivez, el íntimo repliegue, la filosofía específica del sentido egolátrico, tanto como el amor por las grandes causas y la feroz franqueza contra las personas de su desafecto, son aristas supuestamente antagónicas, pero íntimamente unitarias de este grande ejemplar humano, lo mismo en su expresión personal como en el amplio vuelo de su poesía" (Vidales 330-331). La opinión de Vidales, quien después de publicar Suenan timbres -el volumen más aceptado como plenamente vanguardista en Colombia- escribió poesía de carácter social y fundó el Partido Comunista en el país, es en sí misma otra de las muchas caracterizaciones que se adecúan a uno de los numerosos perfiles del poeta, respecto a cuyo conjunto es posible, como se ha visto, emitir múltiples y hasta contradictorios juicios. De ahí la vinculación de De Greiff con las "grandes causas", cuyo nombre pomposo bien podría sumarse a otros que el poeta no cesa de ridiculizar a lo largo de su obra. Ya dijo Fernando Garavito que la profundidad en De Greiff es "como de quien no quiere la cosa, que es, al fin y al cabo, lo que le permite a sus lectores llegar hasta su poesía y hacer con ella lo que quieran" (Garavito 152). El valor de la apreciación de Vidales está, aun así, en tratar de asimilar las contradicciones manifiestas de la figura del poeta bajo eso que llama "la más agresiva consecuencia de su temperamento". La escritura en De Greiff, en particular, es expresión de una subjetividad que no puede clasificarse en esquemas de coherencia tradicional, y ello incide en su confrontación de una tradición en que el sujeto se concibe como un ser unívoco, autónomo y plenamente diferenciado, y no como una integración momentánea de aristas contradictorias que se fusionan y desintegran para volver a integrarse de múltiples maneras. Esa es la base de la vanguardia en su escritura, una subjetividad que rompe con una tradición no sólo colombiana sino hispanoamericana y occidental en general, y que funda una nueva manera de acercarse a ese sujeto cuya solidez se quiebra y cuya definición, por tanto, se escapa del todo en la escritura.
} 
una y de otra para después contradecirlas hasta llegar a contradecirse a sí misma. Y más que contradecirse, se ridiculiza ella misma. La poesía es la defensa orgullosa de una soledad creativa, pero también es la burla a ese narcisismo grandilocuente. La poesía es eso, pero también es más que todo eso. Es la energía expresiva que se alimenta inclusive de su propia naturaleza. Surge en perjuicio de sí misma, de una noción demasiado tradicional de sí misma. En este contexto la contradicción es más que natural, es incluso necesaria. Y a las puertas de una contemporaneidad desestabilizada que ha perdido sus bases religiosas y filosóficas (la "pérdida de la realidad" en un mundo secularizado que tras la muerte de Dios pierde su orientación, según Gutiérrez Girardot, o la "evasión de la realidad fuera de las seguridades metafísicas, religiosas, políticas, que la mente creía guardar a propósito de sí misma”, según Lyotard), De Greiff es el más auténtico de los vanguardistas, dado que confronta el soporte de realidad de una subjetividad estable, la seguridad de una identidad unívoca y autónoma ante el mundo. Su obra es entonces, en virtud de esas contradicciones, tan modernista como vanguardista, tan antigua como avanzada, tan defensora como adversaria de la poesía, tan desencantada como entusiasta, tan unívoca como heterogénea, tan de sí mismo como de sus otras múltiples identidades. En esas circunstancias, no es posible dictar una sentencia que aplique de igual manera a toda ella en su conjunto, si esa sentencia no está mediada por la aceptación de su naturaleza contradictoria. Es necesario reconocerlo para no olvidar que el nuestro es un camino de interpretación entre otros con los que a veces nos cruzamos, y que su grado de confiabilidad debe determinarse por la capacidad de asimilar las señales contradictorias sin dejarse llevar demasiado por una sola de ellas. Con este fin, y a partir del modelo de Wellmer, se ha diseñado un esquema que toma cierta distancia de la sistematicidad clásica y aborda cada problemática como una sección independiente y hasta cierto punto relativa a sus propios motivos, pero en todo caso coherente con un parámetro estructural guiado por la hipótesis de partida, y una función concreta en el conjunto de argumentaciones que crean tensión entre sí. El contraste que subyace a esta tensión es la clave de interpretación desde donde concretaremos, en últimas, las bases fundamentales de esta poética y su grado de participación en la vanguardia. 


\section{EXPOSICIÓN DEL TEMA:}

\section{POÉTICA DEL DESCENTRAMIENTO EN LA OBRA DE LEÓN DE GREIFF}

Es bien conocida la postura de la historia del arte que se refiere a los movimientos vanguardistas de principios del siglo XX como una ruptura radical frente a los valores estéticos del arte del pasado, y como un hito fundamental respecto de otra manera de concebir y desarrollar la práctica de las manifestaciones artísticas en lo sucesivo. En verdad, no es posible ignorar el surgimiento, los logros e incluso los "fracasos" de las vanguardias, al borde de una época en que el arte occidental es cuestionado en sus mismos procedimientos creativos y en el carácter de su participación social, al momento de establecer desde una perspectiva analítica los orígenes de muchas de las concepciones y las prácticas del arte contemporáneo. Numerosos autores se han centrado en esta problemática y la han analizado desde diferentes puntos de vista, con postulados teóricos en ocasiones divergentes, pero siempre encaminados a definir el carácter específico de la ruptura establecida. Algunas de las posturas teóricas más extendidas a este respecto hablan de una crítica al sistema de significación de la obra de arte organicista como expresión de la barbarie en la sociedad capitalista (Adorno), de oposición al concepto de representatividad en favor de la progresiva instauración de una estética de lo sublime (Lyotard), de un distanciamiento del patrimonio de la cultura oficial en la búsqueda del ideal revolucionario decimonónico ya apaciguado por completo en el esteticismo o el decadentismo (Mario de Micheli), o de autocrítica del arte de su institucionalidad burguesa plenamente conformada al fin del siglo XIX (Peter Bürger) ${ }^{27}$. En general, las diferentes posturas sobre la vanguardia

\footnotetext{
${ }^{27}$ En el estudio de esta autocrítica, Peter Bürger habla del concepto de autorreferencialidad, una especie de repliegue temático del arte sobre sí mismo típico del arte burgués finisecular, especialmente del esteticismo. Sobre este concepto volveremos con frecuencia a lo largo del trabajo, particularmente en el capítulo sobre la crítica de la estética modernista. Por otra parte, es preciso establecer desde ya una diferenciación entre el concepto de autocrítica tal como lo emplea Bürger, y la autocrítica que supone la impugnación de un estatus idealizado de la poesía en la obra de De Greiff. Para Bürger, esta autocrítica del arte hacia sí mismo se produce cuando la vanguardia toma distancia de la "institución arte", referida "tanto al aparato de producción y distribución del arte como a las ideas que sobre el arte dominan en una época dada y que determinan esencialmente la recepción de las obras" (Bürger 62). En el caso de De Greiff, y de los inicios de la poesía de vanguardia latinoamericana en general, la protesta contra el arte institucionalizado no se caracteriza por la
} 
europea han girado alrededor de planteamientos teóricos semejantes, que coinciden en señalar las manifestaciones artísticas finiseculares como el resultado de un proceso de desarrollo del arte en la sociedad burguesa, en contra del cual ejercen su crítica los nuevos movimientos.

Por otra parte, es también célebre, en nuestro contexto, la aproximación de Octavio Paz contemporánea a las tesis arriba mencionadas- a la vanguardia literaria hispanoamericana, concebida como un impulso de creación transgresor del canon literario español y del modernismo ya consolidado en nuestro continente, sobre la base de una tensión entre lo local y lo universal. En su primer momento se caracterizaría por un distanciamiento de las vanguardias europeas en favor de un lenguaje auténticamente americano, después de un contacto inicial con éstas por parte de escritores como Vicente Huidobro, y su consiguiente renovación, entre los diferentes escritores involucrados, de la literatura hispanoamericana; en un segundo momento se caracterizaría por la influencia del surrealismo europeo en poetas como Pablo Neruda, definida por el empleo de algunos procedimientos, pero en ningún caso como constitución de un movimiento específico, y en un tercer momento se caracterizaría por la militancia política de muchos de sus exponentes, cercanos a premisas estéticas del realismo socialista (Paz 179-181). Nuestra vanguardia respondería entonces a una doble oposición a la vanguardia europea y al modernismo hispanoamericano, con rasgos auténticos desde sus orígenes a pesar de su influencia externa. Hay otros autores que restringen aún más este grado de influencia y hablan de una vanguardia más determinada por nuestros propios procesos artísticos e históricos, como Gutiérrez Girardot, quien señala que en países como Colombia estos movimientos no surgieron "bajo la influencia de las

vehemencia de corrientes europeas como el dadaísmo o el futurismo, como bien lo advierte Beatriz Sarlo, lo cual no significa en absoluto que no exista esta protesta. En cada caso, hay que establecer el contexto específico en el que se opera la ruptura, con el fin de comprender mejor la naturaleza de ésta y el desarrollo general de la vanguardia de que se trata. En De Greiff no existe una ruptura significativa del aparato de producción y distribución del arte; pero hay que reconocer que estas categorías son radicalmente distintas en sociedades europeas donde a comienzos del siglo XX las formas de producción de la burguesía están en su máximo esplendor, y en sociedades latinoamericanas donde hasta ahora se están implementando. No es correcto, entonces, equiparar sin más ambos contextos y valorar la existencia de las vanguardias en América Latina desde parámetros específicamente europeos. La crítica de la institución del arte en nuestro continente se presenta ante todo como una ruptura en el ámbito de las ideas, y por lo tanto debe referirse al campo intelectual concreto donde tiene lugar, dominado mayoritariamente por ánimos de restauración social en las generaciones centenaristas y por nociones de idealización artística en los sectores más avanzados todavía enmarcados en el modernismo. Este tema será examinado con más profundidad en capítulos posteriores. 
vanguardias europeas, de las que se tuvo conocimiento fragmentario y posterior, sino como el desarrollo dialéctico del modernismo literario y de la modernización social" (Ensayos 82). Por su parte, el crítico colombiano David Jiménez Panesso, en referencia a este planteamiento y sobre una cita de José María Valverde, se adhiere a la misma convicción:

José María Valverde es de la misma opinión, extendida a toda la literatura de América Latina: “también cabría defender que la introducción del vanguardismo a la europea no significó nada esencialmente nuevo para la poesía hispanoamericana, porque el sentido experimental de la imagen y de la exploración estética ya estaba presente en Lugones, López Velarde, Eguren” [...]. Borges mismo, reparando la injuria del manifiesto ultraísta contra el Modernismo, declaró después que en las metáforas de Lugones ya estaba contenida toda la "novísima estética". (Historia de la crítica 172-173, n. 12)

El tema de la distinción de los orígenes de las vanguardias europeas e hispanoamericanas se refiere en todo caso a la diferenciación de los contextos estéticos e históricos que dominan en ambos continentes a finales del siglo XIX. Si bien, como afirma Gutiérrez Girardot, "aunque las sociedades de lengua española no tuvieron en el siglo pasado una clase burguesa amplia y fuerte, los principios de la sociedad burguesa se impusieron en todas ellas $\mathrm{y}$, junto con la ideología utilitarista y la legislación, operaron una honda transformación, semejante, aunque relativa a su tradición, a la que experimentaron los países europeos" (Modernismo 32), no por ello deja de ser evidente que la estructura social era muy distinta. Esto se corresponde con la opinión de Paz respecto al carácter de esta diferencia en el contexto de la poesía finisecular:

$[\ldots]$ hay una diferencia radical entre los europeos y los hispanoamericanos: cuando Baudelaire dice que el progreso es "una idea grotesca" o cuando Rimbaud denuncia a la industria, sus experiencias del progreso y de la industria son reales, directas, mientras que las de los hispanoamericanos son derivadas. La única experiencia de la modernidad que un hispanoamericano podía tener en aquellos días era la del imperialismo. La realidad de nuestras naciones no era moderna: no la industria, la democracia y la burguesía, sino las oligarquías feudales y el militarismo ${ }^{28}$.

\footnotetext{
${ }^{28}$ Paz 132. Respecto a la expresión "oligarquías feudales", empleada en algunos enfoques de la teoría social de América Latina, existen importantes disensos que censuran una homologación inadecuada con los procesos históricos europeos, por la cual se aplicaría erróneamente el nombre de feudalismo al orden económico vigente hasta finales del siglo XIX, justo antes del desarrollo de una burguesía moderna más o menos fuerte. A este respecto, Sergio Bagú asegura que "cuando los historiadores y economistas dicen que el feudalismo,
} 
Según el autor, el modernismo hispanoamericano, como movimiento estético de oposición crítica a la mentalidad positivista decimonónica, se originó primero en nuestro continente, a raíz de una mayor presencia de esta mentalidad en nuestros países en comparación con su presencia en España. Pero incluso este positivismo es de carácter muy distinto al que predominó en el contexto más ampliamente europeo, como el propio Paz lo reconoce, al señalar que "el positivismo en América Latina no fue la ideología de una burguesía liberal interesada en el progreso industrial y social como en Europa, sino de una oligarquía de grandes terratenientes" (127). Este contexto histórico es el que enmarca la consolidación del modernismo y la época de los orígenes de la vanguardia. Los nuevos movimientos, por consiguiente, no se oponen exclusivamente a las concepciones y prácticas del arte en la sociedad burguesa desde lo que Paz llama una "experiencia derivada" respecto a ésta, sino también -y quizá más profundamente si consideramos su importancia histórica en la modificación de las concepciones estéticas en el continente- a una sociedad con fuertes bases señoriales cuyos referentes económicos oscilan entre modelos productivos más bien latifundistas y el incipiente avance hacia un sistema capitalista. Dentro de este marco se despliegan el último modernismo y los orígenes del vanguardismo en el continente, un espacio ambiguo donde los nuevos movimientos desarrollan una respuesta crítica no solamente al modernismo literario ya consolidado sino también a una estética conservadora que ha crecido al abrigo de aquella sociedad señorial y ha constituido su dimensión

agonizante en Europa, revivió en América, se refieren a hechos ciertos: el traslado de algunas instituciones ya decadentes en el viejo mundo; el florecimiento de una aristocracia constituida por elementos desplazados de allá; ciertas características de las grandes explotaciones agrarias, ganaderas y mineras [...] que evocan las condiciones de dependencia de siervo a amo y la beligerancia señorial de la época feudal. Pero todos esos hechos no son suficientes para configurar un sistema económico feudal. [...] Lejos de revivir el ciclo feudal, América ingresó con sorprendente celeridad dentro del ciclo del capitalismo comercial, ya inaugurado en Europa. Más aún: América contribuyó a dar a ese ciclo un vigor colosal, haciendo posible la iniciación del período del capitalismo industrial, siglos más tarde" (Bagú 255). Algo semejante sostiene Luis Vitale, al intentar explicar la condición de atraso de nuestras burguesías industriales en relación con las europeas: "América Latina no ha sido una copia mecánica de la Europa del siglo XIX, donde la nueva clase burguesa en ascenso tuvo que derrocar al feudalismo para iniciar el ciclo de las revoluciones democrático-burguesas. Nuestro continente no atravesó por las clásicas etapas del Viejo Mundo sino que pasó directamente de las comunidades indígenas primitivas al capitalismo incipiente introducido por la colonización española. Al independizarse de España, América Latina no fue gobernada por la fantasmagórica oligarquía feudal sino por una burguesía productora de materias primas que, al depender del mercado mundial capitalista, condicionó el atraso de nuestro continente" (Vitale 459). Para evitar caer en imprecisiones, y sin pretender profundizar en ello, nos referiremos a esta clase socioeconómica, simplemente, como oligarquía terrateniente, denominación menos proclive a generar polémicas, por cuanto es clara su asociación con el espacio de poder concreto ejercido por los grandes propietarios de la tierra en el siglo XIX. 
ideológica. En este contexto social y estético surgen las primeras manifestaciones de un nuevo arte hispanoamericano ya del todo arraigado en el siglo XX, y más en particular la obra literaria que examinaremos en la perspectiva de sus componentes más auténticamente contemporáneos.

No se abordará en principio la cuestión de la pertenencia de León de Greiff al modernismo o a la vanguardia con el objeto de identificarlo por completo con una de estas dos corrientes estéticas, prolongando así un equívoco que ha sido largamente debatido sin profundizar a veces en las características concretas de la obra, y en unos casos con la intención de hacer prevalecer categorizaciones únicas por encima de la multiformidad de aspectos que allí se encuentran. De hecho, una de las premisas de este estudio es la aceptación de la doble naturaleza de esta poesía, como prolongación ineludible de ciertas inquietudes modernistas y su alternancia con procedimientos vanguardistas que escapan por completo al marco estético de la literatura finisecular. Si bien De Greiff comparte con los modernistas influencias y referentes poéticos incuestionables, como la métrica clásica en muchas composiciones o la marcada autorreferencialidad de la poesía, existen otros elementos que lo vinculan de manera indisoluble a estéticas de vanguardia ya del todo lejanas a este movimiento finisecular, como la ironía desintegradora del Yo, la predilección por imágenes asociadas con divagación o la concepción del sujeto descentrado. Son estos elementos de vanguardia los que determinan el enfoque principal del estudio, bajo la convicción de que es allí donde se genera el aporte más original y significativo de esta obra, cuyo análisis es preciso, para dilucidar el carácter del aporte, enmarcarlo en poéticas más contemporáneas. Es la perspectiva más apropiada para integrar en el análisis la naturaleza múltiple de esta poesía, algo que claramente sería imposible desde la mirada restringida del modernismo, por lo demás anacrónica respecto de sus procedimientos más avanzados. En los puntos siguientes nos enfocaremos en esos procedimientos, con objeto de determinar sus funciones en el marco estético de la obra, establecer a partir de ellos la distancia que se genera con respecto a la poética modernista, y comenzar a esclarecer cuál es el papel de la vanguardia en la dialéctica de lo finisecular y lo contemporáneo que aquí tiene lugar. 


\section{VARIACIÓN 1: CRÍTICA DE LA CONCEPCIÓN MODERNISTA DE LA POESÍA}

La poesía moderna europea del siglo XIX, que se extiende desde Charles Baudelaire hasta Hugo von Hofmannsthal, esto es, desde el símbolo como integración de la experiencia moderna en el primero hasta el cuestionamiento sobre la capacidad de representación del lenguaje en el segundo, se nos presenta como una serie de avances hacia la consolidación de la idea de autonomía poética. Esta evolución no se produjo sin el desencadenamiento de conflictos inherente al desarrollo de toda forma artística, siendo posible encontrar en ese contexto discrepancias sobre la definición del carácter de una poesía moderna, tanto en motivaciones temáticas como en modalidades estilísticas. Esto deriva en un panorama heterogéneo y contradictorio de tendencias estéticas. Desde las posturas más avanzadas hasta las más conservadoras, desde aquellas que defendieron el lenguaje de la sugerencia y la belleza de la forma hasta las que insistieron en el papel social y moralista de la literatura, se percibe en todas la presencia de un problema ineludible, cuya solución por parte de las diferentes escuelas o movimientos determinaría su ubicación en ese panorama: la especificidad del arte y su relación con otras manifestaciones de la cultura. La incidencia del parnasianismo y del simbolismo en la idea de la autonomía consolida por caminos distintos la paradoja de la poesía moderna, ya anunciada por la pérdida de la aureola en Baudelaire: la declaración de la independencia de la poesía frente a la sociedad, así esta independencia sea ilusoria, cuestiona la base misma de su función social. Bürger lo explica claramente, en relación con el que considera el último estadio de desarrollo del arte burgués en el marco de la estética finisecular: "Sólo después de que con el esteticismo el arte se desligara por completo de toda conexión con la vida práctica, pudo desplegarse lo estético en su 'pureza'; aunque así se hace manifiesta la otra cara de la autonomía, su carencia de función social" (Bürger 62). El conflicto fundamental al que remite esta problemática es la conmoción de las bases metafísicas de la cultura, intensificada con el auge de corrientes como el positivismo en el siglo XIX, con hondas implicaciones para el estatuto y la práctica 
de la poesía en medio de los demás ámbitos de la sociedad. La defensa de la autonomía, que surge de la asimilación y neutralización parcial de esa conmoción, tiene una doble significación: la consolidación de un campo de parámetros exclusivamente estéticos y el distanciamiento de otros sistemas de significación que en épocas anteriores le otorgaban a la poesía una mayor incidencia en la sociedad, como la política, la moral o la didáctica.

Este proceso se presenta en América Latina desde finales del siglo XIX con el surgimiento del modernismo, cuyos autores se vieron abocados a la reflexión sobre otra concepción de la poesía en una sociedad que comenzaba a asimilar los valores de la burguesía moderna ${ }^{29}$. Desde una postura que abogaba por la ruptura de la tradición de la poesía latinoamericana, el modernismo se nutrió de las escuelas parnasianas y simbolistas, en oposición a los rasgos tardíos del neoclasicismo y el romanticismo ya caducos pero aún frecuentes, impulsando la apertura a estilos formales y representaciones estéticas no acostumbradas en la literatura en castellano. El cosmopolitismo en Rubén Darío, la problemática social contemporánea en José Martí o la rebeldía contra lo establecido en Manuel González Prada, son características fundamentales del nuevo movimiento, así como el simbolismo misterioso de Leopoldo Lugones, la síntesis de misticismo religioso y novedad formal en Amado Nervo o los cuestionamientos a la poesía lírica en José Asunción Silva. En ese contexto, ya del todo conformado, surge la obra de De Greiff como una prolongación de la inquietud modernista por la pérdida del ascendente social de la poesía, aunque con proyecciones vanguardistas en la asimilación de esa pérdida a través de una creación artística abocada a la ironía en contra de sí misma y una suerte de descentramiento del sujeto poético entendido como instancia de unificación estética del universo. En este apartado comenzará a examinarse esta obra bajo ese contexto, con el fin de determinar el carácter de su participación en la coyuntura de la

\footnotetext{
${ }^{29}$ A este respecto, Gutiérrez Girardot aclara que "las burguesías de los países de lengua española fueron reducidas, si se las compara con las de Francia o Inglaterra. Pero el sistema de valores burgueses que se asentó paulatinamente en las grandes ciudades ejerció una 'presión de acomodamiento' en todos los demás estratos de la sociedad, y aunque no modificó automáticamente la estructura, sí transformó las mentalidades, esto es, la selección de las valoraciones, las preferencias por los valores de la nueva sociedad. Esto quiere decir que, aunque las sociedades de lengua española no tuvieron en el siglo pasado una clase burguesa amplia y fuerte, los principios de la sociedad burguesa se impusieron en todas ellas y, junto con la ideología utilitarista y la legislación, operaron una honda transformación, semejante, aunque relativa a su tradición, a la que experimentaron los países europeos" (Modernismo 32. El concepto de "presión de acomodamiento" procede de Niklas Luhmann).
} 
poesía en la época, acudiendo principalmente a tres poemas tempranos que evidencian una postura estética al respecto.

La poesía en De Greiff es la cristalización de un proceso de delimitación de los alcances del símbolo poético, o lo que es lo mismo, de la palabra como material artístico de la poesía. Es un proceso que se remonta a la pérdida de la aureola en Baudelaire, donde la poesía se desliga de esa función casi sagrada que tuvo en el pasado para profundizar en su autonomía secularizada, prolongándose así, hasta la saturación, un lenguaje autorreferencial que es correlato de la pérdida de los alcances de la poesía en ámbitos distintos al exclusivamente estético. Este cuestionamiento de los alcances de la poesía resulta ambiguo en De Greiff, porque su esteticismo abigarrado, que en otras circunstancias podría interpretarse como la defensa de la idea de autosuficiencia del símbolo poético, está atravesado por fuertes dosis de ironía que desfiguran la concepción idealizada del oficio artístico. Es una poesía que evidencia el carácter problemático de su presencia en la sociedad, por medio de una autodefinición elaborada desde la ironía, como se manifiesta ya en el poema inicial de "Tergiversaciones", primer "mamotreto" del poeta ${ }^{30}$ :

${ }^{30}$ La ironía en De Greiff se extiende a la denominación de sus volúmenes de poesía con el título de "mamotretos", "esa palabra que repele, que hiede a cosa vieja, grande, pesada, empolvada" (Cuartas, "León de Greiff' 120. V. pág. 21, nota 17). En los poemas citados se conserva la escritura original de las ediciones de los "mamotretos" empleadas, con la supresión de los signos ortográficos de apertura que caracteriza toda la obra del poeta o la inclusión de diéresis que modifican la métrica de los versos. Por otra parte, no sobra aclarar que la obra se analizará desde una perspectiva de conjunto, confrontando estilos, temáticas o versos específicos con el fin de reforzar las argumentaciones o dar cuenta de contradicciones que se resolverán por medio de las hipótesis propuestas. En razón de esto, no sólo se transcribirán poemas completos como el que sigue a continuación, sino que se abordarán fragmentos especialmente relacionados con el argumento de que se trate en cada caso, y se confrontarán en un mismo espacio de argumentación cuando ello sea necesario. Con esto no se pretende descontextualizar los versos extraídos y confrontados individualmente con otros hasta alterar su significación primaria, por lo cual se harán las salvedades o aclaraciones precisas cuando exista ese riesgo, sino poner en diálogo diferentes momentos de esta poesía, concebida como un todo en donde cada parte no es aislable por completo de las demás, sino que concurre a reconstruir de manera amplia el desarrollo de una poética y a formar el panorama de la concepción estética del autor. Se retoma así la convicción de la mayoría de autores sobre el carácter vinculante de toda esta poesía, expresada -ya lo vimos- por el historiador Andrés Holguín: "De Greiff nos entrega una poesía inconfundible, una de las más enérgicamente personales que hoy se escriben en el país [década del 70]. Su voz no es nunca un eco. Es el instrumento desconcertante de su autobiografía [...]. La poesía de León de Greiff es una prolongada, inacabable confesión. Es también su 'testamento'. Es el testimonio de su vida, de su larga vida de poesía y música, sueño, cultura, vivencias" (Holguín 153). Podríamos agregar -desde una óptica menos biográfica y más centrada en su obra concreta-: el testimonio escritural de las inquietudes poéticas, de las concepciones artísticas y de las intenciones de este "poeta por antonomasia en ese reino del misterio de las palabras" (Acosta 204), en el desarrollo de una nueva estética en el siglo XX. Así lo advierte -también lo vimos- Baldomero Sanín Cano: "De Greiff es 'el poeta'. Toda su vida, toda su inteligencia, todos sus estudios miran a la poesía. [...] Se ha absorbido todas las leyendas mitológicas del oriente y del norte para enriquecer su caudal de imágenes y para ensanchar sus 
Porque me ven la barba y el pelo y la alta pipa

Dicen que soy poeta..., cuando no porque iluso

Suelo rimar -en verso de contorno difuso-

Mi viaje byroniano por las vegas del Zipa...,

Tal un ventripotente agrómena de jipa

A quien por un capricho de su caletre obtuso

Se le antoja fingirse paraísos..., al uso

De alucinado Pöe que el alcohol destripa!,

De Baudelaire diabólico, de angelical Verlaine,

De Arthur Rimbaud malévolo, de sensorial Rubén,

Y en fin... hasta del Padre Víctor Hugo omniforme...!

Y tanta tierra inútil por escasez de músculos!

Tanta industria novísima! tanto almacén enorme!

Pero es tan bello ver fugarse los crepúsculos... (De Greiff, Obras 3)

La existencia del poeta se define en relación con dos identidades, la primera derivada de un estereotipo social de la imagen del poeta -que De Greiff, con pipa y sombrero, se preocupó de seguir fielmente a lo largo de su vida-, y la segunda del ámbito mismo de la poesía, desde comparaciones con poetas imprescindibles en la poética modernista, como Poe, Hugo o Verlaine. La equiparación de elementos mediante el símbolo poético hace converger con armonía el vagabundeo romántico de Byron y las antiguas planicies del rey indígena Zipa, así como la inspiración de una poesía malévola y otra angelical; pero no existe esa misma armonía entre la "industria novísima" o la "tierra inútil por escasez de músculos" y la subjetividad contemplativa que ve "fugarse los crepúsculos". La hipotética plenitud antigua de la relación entre el hombre y la naturaleza, concepto romántico por el cual el trabajo del sustento que ofrece la tierra no es contrario a la sensibilidad estética, ya no es tal plenitud ni reviste condición poética, y la energía romántica del "viaje byroniano" ya no es lo bastante poderosa para hacer suyo "tanto almacén enorme". Es clara la separación entre el ensueño

gustos. Anda por los vocabularios de términos anticuados en busca de palabras cuyas formas y sentidos primitivos se hallen más cerca de los conceptos prístinos de que hace su tesoro el poeta. Saquea los idiomas modernos en el anhelo de buscar voces más precisas, más adecuadas a la emoción del momento" (Sanín Cano 260. V. pág. 29 del presente trabajo). 
poético y las exigencias actuales de la explotación de la tierra. Pero la clave más profunda de esta separación no está en esas oposiciones demasiado convencionales entre los ámbitos de la poesía y la economía, sino en la perspectiva contradictoria que el poeta asume frente al ámbito artístico del que procede: el poeta "iluso", su "caletre obtuso" y su verso "difuso", todo poéticamente unificado por la rima consonante, son nociones que acentúan la condición moderna de extrema incertidumbre a la que se ve abocada la poesía, al ser concebida dentro de un panorama de exigencias sociales y económicas que irrumpen -ellas sí, a diferencia del "viaje byroniano"- en todos los ámbitos de la vida. El último verso, que a primera vista podría interpretarse como la restitución del valor de la contemplación antes impugnada, no logra eclipsar ni resolver la evidencia de una concepción social de la poesía como goce estéril, reforzada con el dardo irónico del "ventripotente agrómena de jipa", imagen del bardo que canta a sus "fingidos paraísos" en campos cuyo trabajo le ha sido vedado a la intuición estética. No son los tiempos del industrioso Virgilio de las Bucólicas. La poesía plenamente diferenciada, fruto del reclamo de autonomía, ha perdido su punto de conexión con las exigencias de la vida moderna. Ahora bien, esta pérdida no desemboca en la búsqueda nostálgica de un orden primitivo. El regionalismo anacrónico y la búsqueda del “origen" naturalista, propios de corrientes decimonónicas contrarias a las dinámicas crecientes de la ciudad, no tienen eco en esta poesía: los "paraísos fingidos" en De Greiff son más cercanos a los paraísos artificiales de Baudelaire, por cuanto - sin llegar a hacer de la ciudad moderna el referente exclusivo de su poesía, como en el caso del poeta francésdenotan una sensibilidad reacia a cifrar sus ideales en actividades rurales idílicas, al anteponer a toda idea de belleza una concepción artística marcadamente esteticista. Este es el sentido del "ya para qué el encanto de la naturaleza" (72). No obstante, como se ha dicho, es un esteticismo que no permanece del todo fiel a su credo de autosuficiencia, como sí sucedía en las corrientes finiseculares, al no ocultar el desprestigio al que se ha visto sometido en un orden social que identifica la poesía con lo "iluso" y lo "difuso", con lo “obtuso" y lo "fingido". Es aquí cuando el poeta reconoce: "me fingí ser un ídolo de laca" (21). Es más bien un esteticismo desencantado de las pretensiones que lo caracterizaban, y que, como dice Eduardo Gómez, testimonia que la lírica está condenada al "marginamiento estéril", por cuanto “depende todavía demasiado del medio que pretende rechazar y se plantea más como distracción sentimental que como proceso hacia una objetividad de la 
sensibilidad y una sensibilización del pensamiento". Así, el poeta sabe que "no le queda más remedio que escribir poemas líricos sobre su imposibilidad de realizarse”, y por tanto está "condenado a una belleza cínica (puesto que es una exaltación de su fracaso y en éste no pretende tener toda la razón)"31 . Pero entonces, ¿cuál es la concepción de la poesía en De Greiff, si lo rural y lo urbano sólo existen en la medida que se funden en un esteticismo concentrado, y al mismo tiempo este esteticismo es falseado por una subjetividad que no parece encontrar una estabilidad ideológica de enunciación? Aquí es necesario detenerse con profundidad en el proceso de desestabilización de la concepción de la poesía en la segunda mitad del siglo XIX europeo, contexto indispensable al momento de perfilar la transición entre el modernismo y el vanguardismo, en cuyos límites surge y se desarrolla la obra del poeta colombiano.

Walter Benjamin encuentra en Baudelaire una especie de perfil del poeta de la modernidad, donde la noción de la aureola, distintivo que hacía del poeta clásico un ser iluminado entre los seres humanos, ya no tiene cabida, pues se ha extraviado en el frenesí de la multitud de la gran ciudad. La pérdida de la aureola en el contexto de la modernidad implica una nueva experiencia para el poeta, quien ahora se ve inmerso, como los demás mortales, en esa dinámica de las multitudes que Benjamin encierra bajo la noción del "shock", una serie de estímulos indiscriminados a la conciencia propia de los contextos urbanos y no compatible con el lirismo idealista que en otras épocas constituía la naturaleza de la poesía. Es esta modificación la que el autor tiene presente al señalar que algunos temas de Baudelaire "hacen problemática la posibilidad de la poesía lírica” (Benjamin 168). Ya no es posible la existencia de una poesía idealizada que actúa como intermediaria entre una colectividad de seres humanos y el misterio trascendental de la naturaleza, al modo como lo proclamaba el romanticismo: en cuanto la poesía se ve inmersa en esa colectividad, ahora compuesta por

\footnotetext{
31 (Gómez 166-167). Cabe anotar lo que Luna Sellés entiende en torno a esta "exaltación del fracaso": "En otras composiciones vemos cómo esa concepción [de la poesía como una práctica casi sagrada en el sentido modernista] se ve distorsionada por el humor, la ironía o por el original tratamiento que recibe, transmitiendo la certidumbre de que la obra lírica es pura voluntad de fracaso. Para explicar esta actitud ambigua debemos situarla en el momento histórico-cultural que se produce. En Colombia, en líneas generales, en esa época, el sistema literario dominante exaltaba la sensibilidad amorosa, estética, patriótica y religiosa. Y la poesía se entendía que debía ser ejercida desde una actitud seria, de 'oficiante'. El ámbito político y cultural estaba favorecido por una hegemonía conservadora y clerical que consideraba la cultura diferencial y aristocratizante y que utilizaba como mecanismo para ejercer el poder la institución de la gramática y de la retórica clásica" (Luna Sellés 276).
} 
la multitud amorfa de la gran ciudad, pierde inmediatamente su ascendente sobre ella. El poeta ya no es un sacerdote en la comunión entre el hombre y la naturaleza. Su sustento trascendental se ha perdido y Baudelaire ha asimilado los efectos de esta pérdida. Benjamin postula que "para Baudelaire está anticuado el poeta lírico con su aureola" (168), con lo que hace referencia a un anacronismo que no sólo es irreversible, sino que se acentúa a medida que el poeta se hunde, anónimo y despojado del distintivo de su sacerdocio, en el tráfico tumultuoso de la modernidad. Por otra parte, esta pérdida de aureola no es sino la primera fase de un proceso que se prolonga a lo largo de la segunda mitad del siglo XIX, hasta su neutralización parcial por parte del simbolismo, con la noción del símbolo poético como instancia de trascendencia en un mundo secularizado que ha perdido su sustento metafísico. Es una trascendencia que sólo puede desplegarse dentro del mundo material mismo, dada la condición irrevocable de aquella pérdida, pero su vuelo se remonta más allá de la existencia secularizada de la modernidad. Se trata de una suerte de trascendencia inmanente que debe su razón de ser a la noción de las correspondencias.

En este punto debemos examinar la doble naturaleza de las correspondencias en Baudelaire, entendidas por Benjamin como "una experiencia que busca establecerse al abrigo de toda crisis" (155), donde crisis se refiere principalmente a la conmoción de las bases metafísicas de la existencia. Por un lado, las correspondencias son de carácter profano al no actuar en regiones de trascendencia cristiana o panteísta, al modo de la poesía romántica de Novalis o Bécquer, pero a su vez superan el vacío metafísico de la modernidad al desplegarse más allá del orden de la experiencia cotidiana. Lo esencial de las correspondencias, según Benjamin, es que "fijan un concepto de experiencia que incluye elementos cultuales" (154). Más allá de su asociación con las sinestesias, lo importante es que rescatan un vínculo con órdenes de existencia que trascienden el presente desmitificado. Estos elementos cultuales, por consiguiente, se integran en la memoria. Son las "fechas de la reminiscencia" sugeridas por Proust cuando habla del tiempo "desintegrado" en Baudelaire, donde "son escasos los días que se abren, y son importantes" (154). La memoria, por lo tanto, acude a rescatar un concepto de experiencia que ya no puede provenir de nociones metafísicas en ruinas sino justamente del recuerdo de lo irrevocablemente perdido, una especie de celebración estética del "encuentro con una vida anterior" (156). Esta condición de la poesía como lugar de la 
caída de las correspondencias de su verticalidad a la horizontalidad, es decir, de su carácter sacro a la inmanencia del mundo material, es un hecho manifiesto desde mediados de siglo, paralelo a la consolidación de la burguesía moderna, en cuyas ciudades prevalece la experiencia de las multitudes que avanzan sobre residuos de aureolas del pasado. La proclama del arte por el arte, el repliegue del arte sobre sí mismo y el misticismo profano alrededor del símbolo y las correspondencias, aspectos que después se intensifican hasta llegar al límite de su sofocamiento, son la radicalización esteticista de una defensa frente a esa crisis de la cultura de la que, según Benjamin, las correspondencias intentan sustraerse. Es sobre todo desde el punto de vista de este esteticismo finisecular que los modernistas hispanoamericanos, sus epígonos declarados, dialogan con la experiencia de la pérdida del sustento trascendental de la poesía y de la figura del poeta como un ser iluminado que guía y enseña a la humanidad. Ahora la poesía es sólo una voz más, engalanada por las virtudes formales de su lenguaje, pero sin un discurso universal que exprese un sentir colectivo. No es más que una redundancia estética sin otro destinatario que el mismo ámbito de la poesía. Este es el espacio de las "Correspondencias" en De Greiff:

La canción ebria! la canción rara!

La que se canta cuando las copas

Prenden incendios en mis estopas!

La canción ebria! La canción rara!

Desequilibrios en libres tropas:

Negros corceles en algazara!

Juegos de faunos en las metopas

Con las nereidas que el juego azara!

La canción ebria! La canción rara!

Regio manteo, toga preclara,

Capa procera con la que arropas

Tus amarguras, bajo la clara

Luz de la luna, cuando galopas

Con tus delirios en libres tropas...

Juegos de faunos en las metopas!

Negros corceles en algazara! 
Capa procera con la que arropas

Tus sueños tristes, tu suerte avara...

La canción ebria! La canción rara! (Obras 22)

Es clara la importancia de la embriaguez como vehículo de correspondencia entre el fuego de la energía dionisíaca y las "estopas" de la inspiración del poeta. Pero es aún más significativa por el hecho de que esta energía dionisíaca ya no es el aliento vital omnipotente infundido por la naturaleza romántica, sino sólo un "delirio" o "desequilibrio" que, lejos de elevarse en un anhelo universal de trascendencia, se ve atrapado en una red de referencias ancladas en el ámbito estético. La experiencia de las correspondencias no sólo ahonda en la horizontalidad de éstas, dada la carencia de una entidad metafísica que vincule el símbolo poético con la eternidad, sino que parcializa sensiblemente esa horizontalidad al afianzarse sólo en la autonomía de lo estético. Si la experiencia de las correspondencias, en palabras de Benjamin, "no es posible sino en el ámbito de lo cultual" y cuando "apremia más allá de dicho ámbito, deberá presentarse como "lo bello" (Benjamin 155), en De Greiff, artífice de un universo poético cuyas coordenadas se traducen en referencias estéticas que representan su propia "experiencia al abrigo de toda crisis", dicho ámbito o experiencia cultual sólo es posible gracias a la existencia previa de la belleza artística. La tesis de Benjamin sobre las correspondencias, en el contexto esteticista, más que revertida se ve entonces intensificada, porque al ser esas correspondencias líneas referenciales que se reconducen hacia sí mismas, sus extremos se conectan y se convierten en círculos referenciales: la celebración estética del "encuentro con una vida anterior" es a su vez esa misma "vida anterior" con que la poesía se encuentra al celebrarse a sí misma. Este narcisismo es el lugar donde se activan las correspondencias y por tanto la experiencia al abrigo de toda crisis. Es el espacio donde la poesía se resguarda a sí misma, redundando en referencias al ámbito estético, como en el "Nocturno $\mathrm{N}^{\circ} 1$ en Si menor (Noche morena)", una de las muchas y recurrentes vinculaciones del poeta entre música y poesía, donde otra vez, además, la embriaguez es fundamental en la consumación de las correspondencias:

Es esta la noche cribada de estrellas?

Manteo raído de poeta pobre

¿Es esta la noche cribada de estrellas parpadeantes, 
(-Taberna donde beben su luz mis sueños sitibundos-,

-Cálidos vinos, ásperas ginebras suaves, whisky, vodka

Que apuré con Mussórgsky; ron antillano: fuertes

Mixturas beben mis sueños en la taberna de la noche-)

Es ésta la noche?

Es ésta la noche donde canta el Silencio?

Es ésta la noche henchida de Inconclusas en germen,

Grávida de la Décima Sinfonía? (Obras 216)

La correspondencia entre poesía y música en favor de un esteticismo reconcentrado es más que frecuente, redundante si se quiere, como en la "noche, piano de ébano: / [...] has de vibrar como la tormenta, al choque de mis rígidos dedos lancinantes" (341); o en el "qué canta el Viento? / La lluvia le acompaña al piano" (210), de la "Fantasía quasi una sonata, en Do Mayor". La poesía redunda en correspondencias esteticistas autorreferenciales, favorecidas por catalizadores como la noche o la embriaguez. El círculo referencial del esteticismo está asegurado. Pero el problema de esta fiesta narcisista, este culto al elemento cultual del arte, esta experiencia en segundo grado de las correspondencias - un paralelo no casual con la tesis de Benjamin sobre el dominio humano de la técnica como segunda naturaleza, convertida en instancia de mediación con la "primera" naturaleza-, es que se trata de una celebración a puerta cerrada que excluye a los no iniciados, quienes por lo demás no encuentran en ella motivo digno de interés. Esta es la relación entre poesía y sociedad en el marco del esteticismo. La poesía reduce sus alcances en el ámbito de la sociedad, en donde representa, en el mejor de los casos, una celebración inofensiva de alucinados, y en el peor, un misticismo anacrónico sin utilidad comprobable. Ya no es más que motivo de risa o de extrañeza. De Greiff lo dice: "Ambulo por las cosas de modo indiferente, / diciendo versos díscolos, ingenuos o sarcásticos, / que así le causan risas o asustan a "la gente" (Obras 9). Esta es la razón del fenómeno al que alude Benjamin al observar que la de Baudelaire es "la última obra lírica que ha tenido repercusión europea", y no sólo, como después postula, los límites de "un círculo lingüístico más o menos reducido" en obras posteriores (Benjamin 167) o que algunos temas del poeta "hacen 
problemática la posibilidad de la poesía lírica" 32 . Baudelaire arroja la aureola del poeta al tráfico de las multitudes. Se integra así a las dinámicas de la urbe, descendiendo al nivel de los "simples mortales" (Baudelaire, Obras 420). Pero no es una integración completa. Al intentar asimilar su pertenencia a una colectividad -ya sea mimetizándose en ella, como el poeta que anhela "el milagro de una prosa poética" nacida "de la frecuentación de ciudades enormes, del cruce de sus innumerables relaciones"33, o con la participación social que años después la vanguardia se propuso como fin-se produce en el poeta una crisis de identidad que se manifiesta, entre otras actitudes, con la hostilidad finisecular hacia esa misma colectividad, en defensa de un aislamiento social que se nutre del fruto doblemente digerido de la autorreferencialidad, esa suerte de segunda naturaleza de las correspondencias a cuyo culto excesivo atribuyó Bürger el atosigamiento del arte burgués. Esa autorreferencialidad es la que desfila por las "Correspondencias" de De Greiff con "regio manteo, toga preclara, capa procera", entre "negros corceles en algazara", "desequilibrios en libres tropas" y “juegos de faunos en las metopas con las nereidas que el juego azara”. Se despliega así toda una red de referencias estéticas que no es sino el aparato fastuoso de un Pierrot ebrio y solitario, sumido en sus "delirios en libres tropas" bajo la "clara luz de la luna". Este poeta ebrio podría sumarse a una tradición de analogías entre el artista y esas figuras históricas de Benjamin que Susan Buck-Morss retoma para aproximarse al arte moderno por medio de

\footnotetext{
${ }^{32}$ No hay que olvidar, por otra parte, que esa "repercusión europea" no es otra cosa que el consenso de una cultura occidental moderna construida desde la pretensión universalista del racionalismo. La consolidación de la autonomía hasta el grado de la autorreferencialidad, en cuanto fragmentación progresiva del universalismo y defensa de la única mística posible para la poesía después de la pérdida de la aureola, es la culminación, en el ámbito del arte, de la negación ilustrada de la Ilustración, un proceso por el cual ésta alcanza su propia liquidación tras haberse ejercitado en la liquidación de las antiguas creencias, al modo descrito por Max Horkheimer y Theodor Adorno: "La propia mitología ha puesto en marcha el proceso sin fin de la Ilustración, en el cual toda determinada concepción teórica cae con inevitable necesidad bajo la crítica demoledora de ser sólo una creencia, hasta que también los conceptos de espíritu, de verdad, e incluso el de Ilustración, quedan reducidos a magia animista" (Horkheimer 66). Así las cosas, la poca "repercusión" de la poesía posterior a Baudelaire es también el síntoma de la crisis de la razón universalista, en cuyo seno la poesía, si bien asociada a tendencias románticas de reivindicación de la irracionalidad, se ha incorporado como uno más entre los diferentes discursos de la razón moderna. Paradójicamente, su aislamiento es el fruto de su integración en la modernidad. Esta es la condición necesaria para que la vanguardia, en palabras de Bürger, pueda reconocer un ámbito plenamente diferenciado entre los demás discursos de la razón, sobre el cual ejercer la autocrítica de la institución artística: "Solamente desde que el arte se ha separado por completo de toda referencia a la vida práctica, puede reconocerse la progresiva separación del arte respecto al contexto de la vida práctica, y la consiguiente diferenciación simultánea de un ámbito especial del saber (el ámbito de la estética) como principio del desarrollo del arte en la sociedad burguesa" (Bürger 63). La poesía guarda en sí el germen de la autocrítica que, según Horkheimer y Adorno, la Ilustración esgrime contra sí misma. En este sentido, forma parte de una dinámica de autodestrucción correspondiente al "proceso sin fin de la Ilustración", al reproducir sus mismas características en calidad de discurso integrado a la estructura reguladora de la razón moderna.

${ }^{33} \mathrm{Ch}$. Baudelaire, citado en Benjamin 134.
} 
analogías: el artista como mendigo que proclama su desprecio por la sociedad y al mismo tiempo como prostituta que se inserta en la "cosificación mercantil" (Buck-Morss 148) de esa sociedad, comparte con el poeta ebrio una marginalidad que en el contexto de la modernidad "adquiere un estatuto casi mítico" (136). Entra así a formar parte de la tendencia colectiva, pese a hacer gala de una independencia que no es sino una postura de autosuficiencia burguesa, la formulación negativa, dentro de las concepciones y prácticas artísticas, de lo que Adorno entiende por "universal mediación de lo social",34.

No obstante, en De Greiff, a diferencia de los poetas del esteticismo finisecular, analogías como esta y la autorreferencialidad en general tienden más bien a cuestionar la concepción elevada de la poesía que en ellos sirve de base a la idea de la autosuficiencia. Es interesante señalar que, si bien los parámetros estéticos empleados en el poema son en su mayoría de origen esteticista, se percibe una cierta distancia respecto a esta corriente, evidenciada al confrontar esos parámetros con algunas implicaciones de las correspondencias en Benjamin. La "experiencia al abrigo de toda crisis" parece tener lugar, efectivamente, en la celebración cultual de lo estético; pero se presenta una contradicción a nivel simbólico entre este abrigo de la crisis y la imagen de la "capa procera", con la que el poeta, lejos de protegerse de las contrariedades, las "arropa" en actitud de protegerlas. Lo que podría ser símbolo de rechazo se convierte en símbolo de asimilación. La poesía no es autosuficiente al no proporcionar al sujeto una complacencia estética por fuera de toda crisis, pero es lo bastante adaptable como para asimilarla y nutrirse de ella, por pequeña o grande que sea. De aquí se deriva una oposición a la estética finisecular basada en la aceptación de la crisis y la poetización a partir de ella, en rechazo de su neutralización puramente ilusoria por

\footnotetext{
${ }^{34}$ En este contexto, una figura histórica como la del mendigo, en su dimensión concreta y sin su contraparte artística, logra remover la seguridad del nuevo orden social desde una negatividad más efectiva que la del poeta inconforme instalado en la comodidad de su torre burguesa. En efecto, "el gesto del vagabundeo apunta en dos direcciones. Es una condena del capitalismo, al que son intrínsecos la explotación laboral y el desempleo. Pero es también, en la sociedad existente, la imagen infernal y negativa de aquello que podría devenir positivo en una sociedad radicalmente diferente. Apunta a un régimen en el que los recortes en el tiempo de trabajo, la producción automatizada y la saturación de los mercados no serían causa de crisis sino el resultado humano buscado. En vez de resultar en una tragedia personal que discipline a los individuos y los vuelva a poner en fila, estos procesos implicarían la realización colectiva de la capacidad para la felicidad y la libertad que una tecnología socialmente organizada podría alcanzar" (Buck-Morss 164). El mendigo proyecta entonces, de manera negativa, la imagen de lo que sería una sociedad burguesa coherente con las premisas de la modernidad, mientras que el poeta que ostenta con orgullo su "autosuficiencia" no es más que la caricatura, vociferante y lujosamente ataviada, de lo que el orden burgués tiene de más injusto e irracional.
} 
parte del esteticismo o del arte por el arte. El poeta lujosamente ataviado, que realiza la celebración cultual de la poesía en medio de un amplio repertorio de referencias estéticas, proviene de la lógica referencial del esteticismo; pero aquí no se configura, como lo pretendió ese movimiento, un espacio del todo vedado a la crisis. La capa procera, símbolo anacrónico, pero símbolo al fin y al cabo, de la antigua grandeza del poeta, sería el más apropiado para cumplir esa función, y sin embargo, en lugar de ello, "arropa" las "amarguras", los "sueños tristes", la "suerte avara". Es un símbolo invertido, o si se quiere, "tergiversado", prolongación de aquello que en otro poema se denomina "mi destartalada 'Torre de Marfil'” (Obras 679). El refugio del poeta ya no es más que una ruina. Pero una ruina de la cual se ha tomado conciencia. Antes que protegerse de las contrariedades, el poeta las acoge y las protege en su fuero íntimo. Se filtran a través de esa capa anacrónica, descrita en otros poemas, irónicamente, como "manteo raído de Villon miserable" (222) o "tabardo astroso" que "cuelga de mis hombros claudicantes y yo le creo clámide augusta" (230). La condición de infortunio es inexcusable, y como tal no es ignorada sino incorporada al desarrollo de una nueva estética. La crisis es inminente, pero en lugar de ser rechazada mediante una ilusoria autosuficiencia poética, se la reconoce y asimila como uno de los referentes estéticos que entran a cuestionar la concepción elevada de la poesía. Se entiende así la figura doble del "pobre mendigo, antaño insaturable, pobre mendigo, hogaño-, de ensueño vagaroso..." (236). Ciertamente, el "arte fuerte" que "posee la eternidad" en Théophile Gautier, o esos poetas "torres de Dios" que resisten "duras tempestades" en Rubén Darío, no tienen punto de comparación con el "mísero trovero, despojo de las éticas", de "pensamiento pobre" cual "monedas de cobre" $(7,9)$, que en De Greiff no parece tener siquiera un lugar en la sociedad, a no ser ese espacio inestable de vagabundeo constante, en forma de caricatura de poeta esteticista, que lo priva de cualquier seguridad distinta a la de lo efímero. El antiguo prestigio, basado en una noción sagrada de la poesía, es confrontado por la idea de un visionario sin visiones, un heraldo sin mensajes, un poeta que impugna los símbolos de su grandeza: "Sueño trovero que ni trova, bardo que ni fabula, vate sin vaticinios, sin enigmas ni oráculos. / Vate vidente: [...] no ve, ni con los mil ojos de Argos" (727). La inversión del esteticismo es múltiple. Dice el poeta: "tan sólo estoy alegre cuando a solas estoy" (5); pero el orgullo esteticista de esta soledad en seguida se desdibuja, al reconocerse que no hay más destino para el poeta que ambular " $[\ldots]$ de 
modo indiferente, / diciendo versos díscolos, ingenuos o sarcásticos” (9). Estos son los mismos "versos de contorno difuso", los caprichos del "caletre obtuso", los "desequilibrios en libres tropas". Se evidencia así lo que separa esta poesía del reducto artificialmente estable del esteticismo, entendido como convicción inalterable y poco problematizada sobre el valor del oficio artístico: la ironía, con la que el poeta ebrio y delirante lleva a término la muerte del arte en la perspectiva de Hegel, por la cual éste ya no es la expresión más alta de la verdad. Y no sólo de la verdad en sentido racionalista, sino de la verdad mística que las estéticas de fin de siglo reivindicaron para sí mismas. Se trata de una doble negación. El romanticismo tomó distancia del racionalismo burgués y el arte finisecular criticó las formas sociales que éste generó paulatinamente, pero ambos defendían todavía una verdad no racional que se expresaba a través de ellos. En cambio, una poética como ésta rechaza toda concepción de verdad, al contradecirla no sólo en su manifestación extraestética sino también en el interior de la expresión poética. Como vagabundo en un mundo sin verdades, donde la verdad es "flor versicolora", el poeta está condenado a una búsqueda de antemano infructuosa: "A través de la Ciudad miserable y sonora / tras la eterna verdad eternamente vague" (7). La autorreferencialidad, que en el esteticismo servía a una autonomía demasiado orgullosa de sí misma, se convierte en ocasión de una crítica de la poesía en contra de sus propias pretensiones, no sólo de su elevación a un altar místico que la separa de la "prosa del mundo", en el sentido en que Hegel la entendió, sino de la expresión de una verdad de cualquier tipo ${ }^{35}$. La ironía es el signo a través del cual se manifiesta esta autocrítica. No hay verso autorreferencial que comporte un esteticismo en apariencia

\footnotetext{
${ }^{35}$ Esta "prosa del mundo" o "estado mundial de la prosa" de las Lecciones de estética de Hegel, en su relación con la "muerte del arte" como expresión más alta de la verdad, es definida por Gutiérrez Girardot como el "estado en el que el individuo es al mismo tiempo medio y fin de otros individuos", característico de una sociedad cuyos principios son "la 'finalidad egoísta en su realización' y la 'generalidad' del egoísmo, que constituyen un 'sistema de dependencia omnipresente' [...] 'Burguesa' es esta sociedad, que en otro lugar Hegel llama el 'sistema de la atomística', porque en ella 'los individuos son, en cuanto ciudadanos de este Estado, personas privadas que tienen como su finalidad su propio interés'. En esta sociedad de ciudadanos (no de siervos), de personas privadas (no de súbditos ordenados en jerarquías), en la que dominan el egoísmo como principio general, las dependencias recíprocas, el interés propio y el principio de utilidad, en este 'estado mundial de la prosa', el arte ya no puede expresar el máximo menester del espíritu, esto es, el hombre con su mundo social, político y religioso concebido como una totalidad sustancial" (Modernismo 28-29. Las citas son de Hegel). En este contexto, la doble negación en De Greiff ahonda en la modificación de la naturaleza expresiva del arte, puesto que además de que éste ya no expresa una "totalidad sustancial" humana -tendencia ya evidente desde Baudelaire y que se afianza con el esteticismo-, la misma totalidad del sujeto dentro del ámbito propiamente artístico se quiebra y se lleva consigo cualquier pretensión de unificación discursiva, o en otras palabras, de verdad en su sentido racional dieciochesco o místico decimonónico. La doble negación de la verdad es la doble negación contemporánea de la "totalidad sustancial" del hombre y de la totalidad subjetiva u organicidad de la expresión artística. Más adelante profundizaremos en este tema.
} 
orgulloso y autosuficiente, sin estar a su vez atravesado, sutil o explícitamente, por fuertes dosis de ironía que rompen con toda concepción idealizada de la poesía. Y no es sólo su definición como verso "de contorno difuso", díscolo, ingenuo y sarcástico, o su comparación con un "capricho" del "caletre obtuso" y con "desequilibrios en libres tropas". Son múltiples autorreferencias en toda la obra, que en lugar de defender una noción decimonónica e idealizada de la poesía, profundizan en su desmitificación contemporánea y su consiguiente revaluación. Es una “tergiversación” irónica del esteticismo, donde se hace explícito el cambio del estatuto de la poesía y su relación conflictiva con la sociedad.

De Greiff encuentra una importante fuente de inspiración en las poéticas finiseculares que proclamaban una autonomía radical de la poesía entre los demás ámbitos o discursos de la modernidad. Pero el esteticismo autorreferencial que de aquí se deriva no se presenta en su poesía sino a través de la ironía en contra de sí misma, lo que genera distancia respecto de concepciones modernistas que aún confiaban en una especie de misión elevada del arte, si bien incomprendida, entre la sociedad. La autosuficiencia tiene otra apariencia, pues si bien el individualismo no cesa de consolidarse - principio éste típicamente burgués tan valioso para el romanticismo y aun para el arte finisecular, pese a consignas en apariencia "antiburguesas" como el épater le bourgeois o el mismo l'art pour l'art-, se trata de un individualismo que antes de ser simplemente autocomplaciente reconoce la crisis de la creación poética en la época contemporánea y la asume como uno de sus motivos principales. Es cierto que el poeta camina "tranquilo y sonriente por las callejas", tan dueño de sí como "indiferente a toda la turba mesocrática"; pero esa "indiferencia" no evita que mencione después, en el mismo poema y de manera explícita, su odio hacia la corrección gramatical que, por lo demás, caracteriza la mayor parte de la poesía hasta el siglo XIX: “sin embargo... y el odio por la Dueña Gramática?” (5). Entonces, ¿es el poeta dueño de su serenidad o está agobiado por este odio? La respuesta es sencilla: en el proceso diacrónico de la enunciación, el poeta está tranquilo en un primer momento, después recuerda su odio y después retorna a la tranquilidad. Todo es sucesivo. O incluso simultáneo, pues hablamos de un mismo poema. El ritmo de la escritura en este caso es el ritmo del pensamiento, que jamás es coherente consigo mismo en todo momento, mucho menos cuando, como aquí ocurre, está dominado por la emoción. La contradicción es recurrente en esta obra y no 
debemos dejar que nos engañe, pues en todo caso remite a una significación que está más allá de la identificación del poeta con una subjetividad concreta, mucho más allá de la seguridad enunciativa de la poesía hasta el siglo XIX, gramaticalmente correcta e idónea para la expresión de la "verdad”. Si bien este poeta, "ácrata anacoreta” (9), afirma que "tan sólo estoy alegre cuando a solas estoy" (5), el lugar de enunciación de esta soledad se problematiza en muchos otros poemas, como el que advierte sobre las "multánimes almas / que hay en mí!” (21). No sólo se parte del esteticismo finisecular para cuestionar el esteticismo mismo, sino que se acude a su reivindicación del individualismo para profundizar en la disgregación de esa individualidad. En lugar de asegurar esa identidad estable, se remueve el lugar de la enunciación y la poesía llega a ser la expresión de una carencia, de una crisis de deslegitimación. La autocrítica de la poesía es la poesía misma. No hay otra verdad que el cuestionamiento de toda verdad mediante un símbolo poético multiforme y contradictorio. La tergiversación es el signo de la autorreferencialidad cuando el esteticismo sólo concurre para cuestionar lo estético. La escritura es el fruto de la ironía con la que se hace frente a la identidad desestabilizada de la poesía y de su función en la sociedad. Estamos ante una poesía que debe ser interpretada desde parámetros distintos a los del modernismo, tan abocado a la defensa del valor intrínseco del arte como un oficio autónomo plenamente dominado por una subjetividad diferenciada. La crisis de la concepción suprema de la poesía es la crisis de su propia identidad, más o menos estable hasta el fin de siglo. La desestabilización de las bases de la cultura, que suprime todo prestigio incuestionable y todo espacio firme de enunciación, otorga a esta poesía ciertos perfiles que sólo pueden ser analizados desde posturas vanguardistas, lo cual, más allá de la reivindicación específica de ciertos componentes de avanzada, supone la apertura de un panorama que contribuye a esclarecer mejor el conjunto de esta obra a la luz de la dialéctica entre dos estéticas. Como señala Luna Sellés, la vanguardia en De Greiff se deriva de la contradicción y puesta en escena de concepciones modernistas y antimodernistas, puesto que sólo puede serlo “dialogando, aceptando, difiriendo, deslindándose del modernismo hispanoamericano y de los autores románticos y simbolistas que fueron para él señeros” (Luna Sellés 273). En esta relación dialéctica está la clave del distanciamiento de la poética finisecular, la clausura de concepciones y prácticas por lo demás ya institucionalizadas, en cuya negación está la base de un sentido vanguardista frente a la tradición de la poesía 
colombiana e hispanoamericana, y que desarrolla así, en consecuencia, su propio horizonte de vanguardia. 


\section{VARIACIÓN 2: \\ POÉTICA DE LA DIVAGACIÓN}

La crisis de las concepciones decimonónicas de la poesía a las puertas de la vanguardia histórica entraña una serie de factores asociados no sólo con la saturación y el consiguiente fin del esteticismo finisecular, que para Bürger es el último momento del desarrollo del arte burgués tal como se ha conformado desde el Renacimiento, sino con la desestabilización de una subjetividad unívoca que antes se sustentaba en la idea de un sujeto indivisible y enteramente rector de una postura epistemológica concreta. La disgregación subjetiva producida por esta desestabilización se corresponde con propuestas estéticas como la manifestación del subconsciente en el surrealismo o la multiplicidad de puntos de vista en el cubismo, e incluso con el nihilismo autodestructivo en el dadaísmo. Entre sus signos más visibles figuran, entonces, el surgimiento de múltiples Yo, la inorganicidad de la obra y el rechazo del arte desde el arte mismo. Estas modalidades de la vanguardia forman parte de las condiciones en que se llevaría a término, eventualmente, el objetivo explícito de algunos manifiestos, esto es, la unión de arte y sociedad con miras a una modificación estética de ésta. No obstante, este impacto social fue entendido por la vanguardia como consecuencia última de una previa modificación de los procedimientos artísticos, lo que debía tener lugar, evidentemente, en sus materiales de expresión. La liberación social del individuo en la consecución de una sociedad ajena a ideas y prácticas de represión, perspectiva última del surrealismo, es sólo un escenario posible de incidencia a partir del material artístico en cuestión, cuya crítica de la tradición y modificación de prácticas anteriores, en este caso, son decisivas para la historia del arte del siglo XX. Por ello, el fracaso ulterior del propósito de impacto social no implica el fracaso a gran escala de la vanguardia, como parece derivarse de la terminología de algunos autores. La modificación del material artístico fue irrevocable en el desarrollo de la estética y el arte posteriores, pues ya no fue posible una reflexión más o menos concienzuda sobre nociones y prácticas artísticas que no tuviera presente $-\mathrm{y}$ en cierto modo lo trajera de nuevo a un momento de la posteridad, haciéndolo 
presente una y otra vez- el hito fundamental de los movimientos de vanguardia. Nos detendremos entonces en este ámbito del material artístico, más allá del "logro" o "fracaso" de una acción social específica y más bien complementaria ${ }^{36}-\mathrm{y}$ por tanto de formulaciones no artísticas en este sentido por parte de los mismos vanguardistas, que pierden así algo de la exagerada importancia que se les suele prestar en la definición de sus prácticas artísticas concretas-, para abordar la problemática de la desestabilización del sujeto y su lugar en la obra en cuanto procedimiento vanguardista no determinado por la explicitación de un deseo de "cambio social" no valorable artísticamente, sino por la noción descentrada de una expresión poética concebida en épocas anteriores como la enunciación de un sujeto estable y unívoco, presente por lo demás en los diferentes discursos de la razón moderna. Se trata pues de valorar la vanguardia, en sus procesos artísticos concretos, en función de su crítica a los parámetros de la tradición estética de la modernidad -sustentados en una noción estable de la subjetividad al igual que los demás discursos de la razón moderna-, antes que hablar de su papel frente a esa tradición desde fórmulas y programas no valorables en una dimensión artística, que entran más bien en la categoría de eventualidades contingentes de esos procesos, y hasta de lo meramente anecdótico cuando, como en ocasiones ocurre, se prescinde por completo del análisis de la obra.

No hay que olvidar aquí la situación especial del continente en la consolidación incipiente de una burguesía en la época del cambio de siglo, pero tampoco radicalizar un aislamiento de esta formación social que de ningún modo corresponde a la realidad, como se ha dicho antes. Los vestigios de las oligarquías terratenientes, progresivamente influenciadas por valores burgueses en aspectos claves del orden social, se transforman en un espacio de conflicto en el que algunos rasgos de la mentalidad moderna concurren al desprestigio

\footnotetext{
${ }^{36}$ Se dice que es "complementaria" no porque el ámbito estético se considere de todo punto de vista ajeno a otros órdenes o discursos de la sociedad, con lo cual se reafirmaría la pretensión de autonomía radical del arte de finales del siglo XIX, y se redundaría en el "fracaso" de las vanguardias que no habrían podido superar la idea de la autonomía. Más exactamente, se entiende por "complementaria" una proyección fuera del ámbito estético que en realidad no podría llevarse a cabo sino de cierta manera indirecta, pues de creerse lo contrario se olvidaría que a lo estético no le es posible, ni necesario además, sacrificar sus cualidades para trascender a otros discursos de la sociedad, como lo plantea Adorno al hablar de una soberanía del arte que no puede ser concebida más allá del espacio de su propia autonomía, o sea, una crítica de lo extraestético que no puede darse sino en el ámbito de lo estético. El arte no es autosuficiente, pero tampoco tiene una existencia no estética, pues lleva consigo el germen de lo estético. Más adelante profundizaremos en esta temática, al momento de establecer la dialéctica entre el modernismo y la vanguardia en De Greiff.
} 
progresivo de diferentes sistemas de valores, no sólo en el arte y la literatura sino en otros ámbitos de la vida. Es lo que Gutiérrez Girardot entiende como la consolidación de los valores de la burguesía en el fin de siglo, desde antes de la modificación de sectores estructurales de la sociedad, a través del concepto "presión de acomodamiento" de Niklas Luhmann:

Las burguesías de los países de lengua española fueron reducidas, si se las compara con las de Francia o Inglaterra. Pero el sistema de valores burgueses que se asentó paulatinamente en las grandes ciudades ejerció una 'presión de acomodamiento' en todos los demás estratos de la sociedad, y aunque no modificó automáticamente la estructura, sí transformó las mentalidades, esto es, la selección de las valoraciones, las preferencias por los valores de la nueva sociedad ${ }^{37}$.

Este avance del sistema de valores burgueses es la consecuencia natural de un proceso de incorporación del continente a modelos sociales y económicos europeos que alcanzan su mayor auge en las décadas próximas al cambio de siglo. José Luis Romero, hablando sobre el apogeo de la mentalidad burguesa europea hacia esta época y su penetración en América Latina, lo explica de la siguiente manera:

Si la época que transcurre entre 1880 y 1930 tuvo una definida e inconfundible fisonomía fue, sobre todo, porque las clases dominantes de las ciudades que impusieron sus puntos de vista sobre el desarrollo de regiones y países poseyeron una mentalidad muy organizada y montada sobre unos pocos e inquebrantables principios que gozaron de extenso consentimiento. Eran ideas muy elaboradas y discutidas en el mundo, muy ajustadas a la realidad socioeconómica y política, y con ellas había elaborado la burguesía europea, en su época de mayor esplendor, una forma de mentalidad que entrañaba una interpretación del pasado, un proyecto para el futuro y todo un cuadro de normas y valores: triunfante, la gran burguesía industrial ofrecía el espectáculo del apogeo de su mentalidad

\footnotetext{
${ }^{37}$ Gutiérrez Girardot, Modernismo 32. Estos valores burgueses son brevemente expuestos por el autor en su definición de la formación social: “'Sociedad burguesa' o 'sociedad civil': este nombre designa primeramente un sistema de valores, los de los intereses privados, los de la utilidad, los del hedonismo, los del lujo, los de la riqueza, los de la 'democracia', los que resumió Louis Philippe, el rey burgués, en la consigna 'enriqueceos'. Es un nuevo 'horizonte de la vida', anterior y presupuesto de lo que se ha llamado la 'clase burguesa"' (31). Gutiérrez Girardot se detiene también en la función de la ideología utilitarista y la legislación cuando señala que la "recepción del código napoleónico [aceptado por las repúblicas latinoamericanas desde mediados del siglo XIX, en la adaptación de Andrés Bello, y con el que se imponen los "principios racionales y capitalistas"] la preparó y acompañó la difusión del utilitarismo de Bentham y de la ideología de Destutt de Tracy tanto en España como en Latinoamérica. Lo que, para el caso, importa comprobar es que tanto la introducción del derecho civil napoleónico como la de las ideologías utilitaristas de Destutt de Tracy y de Bentham no solamente impusieron los principios de la sociedad burguesa, sino que conformaron la vida y mentalidad de las sociedades de lengua española" (30).
} 
triunfadora. Era inevitable que, entre tantas cosas, también aceptaran las burguesías latinoamericanas ese modelo de pensamiento de eficacia probada. [...] Entretanto, una fuerte presión de los centros de poder procuraba perfeccionar la incorporación de Latinoamérica en la esfera de su influencia. La consecuencia necesaria fue que las nuevas burguesías latinoamericanas, al adherir a la tesis de que había que consumar el proceso en el que el mundo estaba empeñado, aceptaran todo el sistema interpretativo y proyectivo de la mentalidad burguesa triunfante (Latinoamérica 307-308).

Las sociedades latinoamericanas de los años próximos al cambio de siglo son el resultado de un conflicto entre las tradiciones de lo que Romero llama el "patriciado" decimonónico, formado por las clases acomodadas desde antes de la Independencia y las que prosperaron en los conflictos posteriores, y la gran burguesía que empieza a consolidarse a finales de siglo. El avance de la mentalidad burguesa en un contexto social en que aún prevalecen rasgos estructurales de las oligarquías terratenientes dominantes en el siglo XIX, es un presupuesto fundamental en la comprensión de aspectos claves del campo intelectual en general y literario en particular, como el origen del modernismo, inspirado en la poesía europea más contemporánea, en oposición al hispanismo y el neorromanticismo, de cuño tradicionalista y enemigo de las influencias "foráneas" - entiéndase no españolas- de aquella corriente. Sobre estos pilares básicos, uno conservador y otro más avanzado, se conforma la literatura latinoamericana de principios del siglo XX, un espacio de conflicto en que la defensa de una idea de nación arraigada en lo tradicional, tendencia después encarnada por las generaciones centenaristas en algunos países del continente, se contrapone a las renovaciones introducidas por las influencias francesas e inglesas, situadas al otro extremo tanto del espectro estético como del ideológico. En esta lucha se forma la tradición literaria frente a la cual los movimientos vanguardistas establecen su protesta. No se trata del distanciamiento de una estética del todo enmarcada en un orden social burgués como en el caso europeo, donde la oposición entre las ideologías del campo y la ciudad ya se había resuelto en favor de esta última, sino del distanciamiento de un espacio ambiguo en donde los nuevos valores del lucro y la economía liberal conviven con formas señoriales fuertemente arraigadas en la posesión de la tierra. La protesta no se genera en consecuencia en el interior de una sociedad burguesa plenamente establecida y de las formas artísticas que han surgido y alcanzado su máximo desarrollo en ella, hipótesis fundamental del análisis de Bürger, sino en medio de la síntesis de diferentes formas sociales y artísticas que 
deben ser examinadas con parámetros distintos. En nuestras vanguardias se perciben rasgos fundamentales que son comunes a sus homólogas europeas, como la desestabilización más o menos evidente de la subjetividad, la inorganicidad de la obra o la autocrítica de los fundamentos del arte; pero cada uno de estos rasgos se inscribe en condiciones históricas y estéticas diferentes que le dan otros significados e implicaciones. La despersonalización subjetiva o la desestructuración de la obra se oponen no solamente a las concepciones del arte en las estéticas finiseculares de avanzada, sino también a una estética tradicional que todavía influye de manera determinante en los gustos artísticos. Cuando Huidobro empieza a difundir su ideario vanguardista en 1914 con la lectura de su manifiesto, diferentes generaciones centenaristas en varios países de América Latina ya estaban inmersas en un proceso de conciliación con la cultura hispánica y de reconfiguración de los destinos nacionales después de la agitada historia política del siglo XIX. El clima de restauración es generalizado tras una larga serie de guerras civiles donde se enfrentaron diversas ideas acerca de lo que deberían ser las bases políticas de las nuevas repúblicas, en una coyuntura histórica distinta a la de Europa, donde los conflictos políticos de gran envergadura están por llegar a su máxima plenitud. La actitud vanguardista, que allí se inicia como la crítica a la estética e ideología burguesas próximas a entrar en crisis, en la literatura de América Latina es la respuesta a un panorama dominado por dos tendencias contrapuestas pero en últimas convergentes en su papel de definición de una poética más o menos regionalista o cosmopolita en los primeros años del siglo XX. Este es el ambiente literario en el que surge la protesta de los nuevos movimientos, y hay que caracterizarlo para entender mejor el origen y el desarrollo de éstos. La ruptura estética debe examinarse desde la perspectiva de la tradición literaria en la que se inscribe, pues de lo contrario sólo la entenderíamos como una imitación sin sustento alguno -incluso sin gran efecto- en el contexto histórico al que pertenecen. En efecto, como señala Beatriz Sarlo, “el cambio de las formas y la transformación de las costumbres literarias se manifiestan como 'vanguardia' cuando existen actores y relaciones institucionales que pueden definirse como propios de un campo intelectual desarrollado" (Sarlo 212). En esa perspectiva, los nuevos movimientos convierten al campo intelectual, entendido en la línea conceptual de Bourdieu, en escenario de la "ruptura estética típicamente moderna" de la vanguardia, e introducen una protesta que incumbe a formas ya establecidas en ese campo intelectual. La vanguardia se define 
como tal sólo en su relación con los demás componentes del campo intelectual en el cual llega a operar sus transformaciones. Por ello, si bien no es posible concebir la vanguardia latinoamericana como expresión aislada del contexto de la literatura europea y occidental, es necesario enmarcarla en el espacio intelectual concreto donde surge y así evaluar su grado de innovación respecto a lo ya establecido, pues es esta relación, exclusivamente, la que determina su calificativo de "vanguardia".

La contraposición entre lo tradicional y lo cosmopolita, entendido éste según el esteticismo europeo finisecular, que está en el centro de la literatura latinoamericana de principios del siglo XX, es entonces uno de los referentes que la vanguardia llega a contradecir y a intentar superar. El regionalismo de las generaciones del centenario es claramente una tendencia tradicionalista y defensora de la ideología decimonónica más conservadora, lo cual entra en conflicto con las posiciones más avanzadas de la vanguardia. Poco tienen en común la nostalgia del colombiano Tomás Rueda Vargas por el orden patriarcal antiguo de la región del centro del país y la deformación de las perspectivas tradicionales de la ciudad moderna por parte del vanguardista Luis Vidales. Pero también el modernismo, en su tiempo la corriente más revolucionaria de nuestra literatura, es ya una escuela plenamente asimilada e incorporada a la cultura institucionalizada con posiciones de privilegio en el campo intelectual. Es el caso del poeta Valencia en las primeras décadas del siglo XX en Colombia, en cuya obra se ha hecho evidente, con el paso de los años, un modernismo demasiado anclado en fórmulas establecidas que en otro tiempo fueron contestatarias, y la legitimación de un gusto elitista no radical ni marginalmente estético, como en muchos poetas modernistas, sino en armonía con los intereses de la clase privilegiada a la que perteneció y a través de la cual ejerció gran influencia en sectores políticos y económicos. Por ello, la vanguardia surge como una revolución en el seno de un ambiente intelectual plenamente legitimado y se alza contra lo tradicional regionalista y lo "modernizante" anquilosado. Mientras la vanguardia en Europa se opone a una autonomía surgida de la ideología y la experiencia inmediata de la sociedad burguesa, en América Latina es la oposición a dos tendencias predominantes en la época: la perduración de una tradición social más bien patriarcal con fuertes referentes hispánicos, y la plena asimilación del modernismo en el ambiente literario más tradicional y legitimado. El estridentismo se 
integra al proceso de renovación social en México tras la depuesta hegemonía de Porfirio Díaz y ubica entre sus blancos de ataque al modernismo tardío de Enrique González Martínez; la vanguardia argentina de la revista Martín Fierro rompe con la vertiente nacionalista de la generación del centenario y con la figura señera del modernista Leopoldo Lugones, quien es confrontado de manera explícita; el negrismo en Cuba rechaza la ideología de las clases dominantes fuertemente racistas y resguardadas en el modelo de explotación de los ingenios azucareros, y por último, la sombra de Darío es desafiada en Nicaragua en la crítica a sus numerosos imitadores. La convergencia eventual de estas dos tendencias, tradicional y modernista, genera lo que en algunos países fue la defensa de un orden estético e ideológico anacrónicamente patriarcal, aferrado al boato del modernismo y en aras de un elitismo enmarcado en instancias políticas y económicas más influyentes que la exclusivamente estética. En Colombia, este fenómeno es ilustrado, de nuevo, por la figura de Valencia. Gutiérrez Girardot, para quien el modernismo del poeta no es más que "artificial” o "superficial”, indica que "lo cierto es que su poesía cabe ser considerada como una interpretación de 'su pueblo' [en alusión irónica a ciertas declaraciones en este sentido], si pueblo no se entiende en el sentido moderno que comenzó a adquirir con la Independencia sino en el sentido genitivo que éste tiene en una sociedad señorial y en un país de tercos hábitos monárquicos como Colombia” (Ensayos 32). La formación del campo intelectual de principios del siglo XX es particular en este país. Como en pocos, ilustra a la perfección la convergencia de estéticas en apariencia contradictorias en el mantenimiento de un orden social dominado por las mismas clases privilegiadas del siglo XIX. Así lo señala Gutiérrez Girardot en su equiparación del modernista Valencia y el centenarista Rueda Vargas, aludiendo a una "cultura de viñeta", con que refiere la simple reproducción de tópicos literarios e históricos explorados hasta el cansancio por la corriente modernista y ahora legitimadores de una clase señorial "naturalmente" detentora del lujo y la cultura universal:

Aunque a primera vista la obra de Guillermo Valencia y la de los contertulios de La Gruta Simbólica [especie de bohemia trivial de clase acomodada] Puede aparecer diametralmente opuesta a la de Tomás Rueda Vargas [...], las tres son solamente aspectos de la cultura señorial de viñeta. [...] Los aspectos exteriores de la poesía de Valencia y que suelen resumirse en la calificación de parnasiano contradicen el casticismo santafereño de Rueda Vargas a primera vista tan radicalmente que no parece posible 
encontrar alguna relación entre ellos. [...] Pero los aspectos externos que diferencian tan radicalmente al Goethe venerado en Popayán y al "neogranadino" Rueda Vargas pierden su aparente carácter diferenciador cuando se mira de cerca la obra de los dos. Con menos algarabía que Valencia, Rueda Vargas cultiva la cultura señorial de la viñeta, y aunque los elementos que en este la constituyen son reminiscencias de la Colonia, el resultado es el mismo en los dos: la trivialización. Rueda Vargas no ornamenta sus castizas charlas con figuras de la mitología y de la historia literaria. Su lugar lo ocupan las "señoras descendientes de virreyes, de oidores, de capitanes y de encomenderos", de quienes los "descendientes despojados" de la población prehispánica esperan que "la luz de vuestros ojos vaya a iluminar su opaco espíritu" para que se cumpla "el noble intento de la Reina Católica”, es decir, el de "dar al fin, con un inteligente y real cuidado de nuestras gentes, a la palabra encomienda su verdadero significado, el que quiso imprimirle y no logró que tuviera, el alto espíritu de doña Isabel de Castilla”. (Ensayos 46-47)

La literatura colombiana de principios de siglo es entonces una suerte de connivencia de clases ilustradas de una y otra tendencia que contribuyen a la conservación de la cultura señorial, sin perjuicio de emplear elementos modernistas antes revolucionarios y propios de la mentalidad moderna, pero ahora invertidos en sus intenciones de sacudimiento de las ideologías establecidas. En efecto, sobre el cosmopolitismo y el hedonismo modernistas, y su empleo en Valencia, continúa Gutiérrez Girardot:

Dibujada con trozos de procedencia cosmopolita, la viñeta no pierde por ello su carácter de reproducción; antes por el contrario, la neutralización provinciana del cosmopolitismo lo hace más patente. A la viñeta se agrega siempre el rasgo castizo y ancestral: "se veía allí la espada / con un león por puño y contera labrada". El hedonismo, que caracteriza a la Modernidad y al que corresponde el Modernismo de Darío, constituye aquí sólo un barniz de la "cultura señorial", que, pese a su superficialidad y subalternidad, se convirtió en Colombia en un sigo de aristocracia y de superioridad social. En esta cultura señorial y de viñeta se dio a la mediocridad el valor de grandeza, y al sustituto torpe de la cultura originaria se lo consideró como creación superior a su modelo. (Ensayos 34)

Quizás este sea uno de los motivos de la admiración desmedida que se le tributó a Valencia en vida y aún muchos años después de muerto en amplios sectores del ambiente intelectual colombiano. En plena República Conservadora, instaurada hacia 1880 y prolongada hasta 1930, su "modernismo" fue el signo distintivo del buen gusto literario. De este modo, una estética finisecular de avanzada, que inauguró en el continente la primera corriente literaria del todo original, terminó por convertirse en lo que Gutiérrez Girardot llama “estética de la 
dominación", la legitimación de una clase señorial reinante que no estaba dispuesta a perder sus privilegios y cuyo régimen se consideraba entonces la "cifra de la nación" (32). Este es el contexto en el que surge la ruptura de la vanguardia en Colombia, encarnada por pocos autores pero no por ello menos contestataria. La convergencia de las ideas centenaristas y un modernismo estética e ideológicamente falseado es un aspecto clave para comprender el origen, el carácter y el objetivo de la protesta. La vanguardia, en cabeza de Luis Vidales y De Greiff, y en cierta medida de Luis Tejada, reaccionó en principio contra un ambiente intelectual estático en que hasta las corrientes de avanzada parecían invertirse y adormilarse en la tranquila comodidad de la clase señorial dominante. De nuevo, Gutiérrez Girardot describe ese ambiente estático dominado por dos tendencias no tan contrapuestas al final, y sus implicaciones en una mirada crítica de la historia:

[...] en Valencia y en Rueda Vargas, el ornamento aparentemente cosmopolita del uno y la reminiscencia restaurativa colonial del otro, conducen a una concepción de la realidad histórica que no solamente es excéntrica porque desconoce el paso mismo de la historia sino porque reduce la historia a anecdotario, esto es, a viñetas. Fijada en esas estampas, la historia de Colombia adquiere un carácter estático e insustancial que hace imposible y hasta innecesario preguntar críticamente por la significación actual de las "señoras descendientes de virreyes" y de los "descendientes despojados" en el desarrollo o estancamiento de la sociedad colombiana y sobre todo en el contexto de la historia moderna. (Ensayos 48)

En esta especie de tiempo sin historia, la primera crítica que se revela necesaria es la crítica al estatismo ideológico que gobierna los círculos literarios más influyentes del país. Y para esto es preciso introducir un elemento disociador de esa tradición de estatismo, tanto en su vertiente tradicional como en la modernizante ya neutralizada. Este elemento, más o menos agresivo estética o ideológicamente, es el que proporcionan los miembros de Los Nuevos, grupo sumamente heterogéneo sin programa definido pero dispuesto a combatir la tradición intelectual en conjunto, al que perteneció De Greiff, así como también Vidales y Tejada. La oposición del grupo no fue sólo estética, puesto que algunos no practicaron en absoluto arte o literatura sino que se decantaron por el periodismo o el escrito político. Las posturas radicales de rechazo a la tradición son evidentes desde los primeros editoriales de la revista del mismo nombre que fue su órgano de difusión. Refiriéndose tanto a la grandilocuencia que había alcanzado la generación del Centenario, como al privilegio de que gozaban al 
tener a su disposición los medios de difusión de mayor alcance, Alberto Lleras, uno de los directores de la revista, les increpa:

[...] entre toda su obra encontramos cosas eminentemente deplorables y desgraciadamente no deploradas por ustedes. [...] Han perdonado todo, y han aplaudido cualquier acto de un miembro de su generación con una lascivia que nos escandaliza. Por todas partes el ditirambo hiperbólico, hinchado, sin respetar nada. Y para eso, desgraciadamente se han servido ustedes de las prensas que tienen a su disposición. Desgraciadamente porque esas prensas son hábilmente dirigidas y porque hábilmente dirigen la opinión del país ${ }^{38}$.

Es claro el rechazo a la estética de la generación del Centenario y a su influencia manifiesta en los círculos de “opinión”. En respuesta al ataque de Agustín Nieto Caballero, uno de sus más ilustres miembros, a "los alegres muchachos que nos hemos congregado aquí", Tejada habla además del sentido político de estos respetables y cautos caballeros, señalando que "se le puede abonar también a esta famosa generación su innegable honradez política, esa cualidad sublime y estéril que alcanza con frecuencia los límites de la más auténtica tontería" (Tejada 328). Jorge Zalamea, otro de Los Nuevos, los vinculó después al "gigantesco proceso de mixtificación [del conservatismo] que tuvo a la República entelerida durante treinta años bajo el diluvio retórico más prolongado y caudaloso que haya soportado nunca pueblo alguno", y los responsabilizó de fomentar "una casta señorial que no pasará del medio millón pero que se da el lujo de vivir de espaldas a los siete y medio millones restantes de colombianos" $" 39$. La resonancia política del ideario centenarista

\footnotetext{
${ }^{38}$ A. Lleras, citado en Medina 212. Estas declaraciones contestatarias, entre las muchas y muy variadas que se expresaron en la revista, son las más relevantes desde una mirada actual, por lo que significan en un ambiente intelectual excesivamente plegado a modelos antiguos y consagrados. Pese a la multitud de ideologías que allí se mezclaron, algunas del todo retardatarias y rechazadas después por el consejo editorial, en lo que parecía ser una falta de claridad ideológica a veces corregida sobre la marcha, se generó en ella una cierta actitud de conjunto que, si bien carecía de criterios precisos, se propuso combatir lo que sus promotores consideraban lo "viejo". Esto no impedía, desde luego, que lo "viejo" fuera diferente dependiendo de qué "nuevo" lo atacara, o que, como ocurrió en efecto, unos "nuevos" se pasaran después al partido de lo "viejo", entendido éste, claro está, en el mismo sentido que antes le habían dado al atacarlo. En todo caso, los más vanguardistas de Los Nuevos, el ala de mayor peso entre sus integrantes, manifestaron en su momento una actitud radicalmente opuesta a generaciones defensoras de estructuras patriarcales decimonónicas, y en esto estriba su importancia histórica, como instancia de crítica al orden establecido y a la estética en que se fundamentaba su ideología. El presente texto, como es natural, optará por el enfoque en esta tendencia de avanzada, y se hará referencia a ella en particular al emplearse la denominación genérica de Los Nuevos, a menos que se indique lo contrario, considerando que su núcleo fundamental y sus motivaciones de origen se decantaron hacia esta tendencia.

39 J. Zalamea, citado en Estripeaut Bourjac 740 y 744. La población estimada corresponde a la década de 1920.
} 
es evidente. Sin embargo, como se ha expuesto, este grupo no es más que una vertiente de un campo intelectual formado por dos tendencias que contribuyeron, cada una a su manera, a la perduración de la estética y la ideología de la cultura señorial y conservadora. Por eso Tejada rechaza tanto a los centenaristas como a Valencia, el ilustre modernista que domina el panorama del buen gusto literario en la Colombia de principios del siglo XX, cuya obra dice que es "fruto de una inteligente piratería ideológica al través de todas las literaturas" (316). Pero además de referirse a su obra en particular, en términos que después retoma Gutiérrez Girardot, lo asocia con un reducto modernista al que considera más preocupado por la erudición y la imitación que por la creación auténtica, insistiendo después en el carácter espurio de su obra:

[...] Valencia pertenece a una generación perfectamente definida en América, generación erudita meritoria, pero vieja e inútil ya, puesto que ha cumplido totalmente su misión histórica; [...] es la generación de Rodó, de García Calderón, de Sanín Cano, de todos esos amables diletantes que no han tenido una inspiración original, un fermento espiritual propio, una visión personal de la vida y de la naturaleza y se han limitado a interpretar, ampliar y difundir las ideas, las teorías y los sistemas que otros crearon en lejanos países. [...] El caso de Valencia es mucho más esencial y más trascendental [que el de los "poetastros descarados" que firman como suyos textos de otros]: lo que él ha usurpado a otras literaturas, no son unos cuantos versos sueltos, sino la inspiración inicial de toda su obra: en él no hay nada personal, nada terrígeno, nada que pertenezca a nuestro ambiente peculiar [...]; sus cigüeñas, sus camellos, sus centauros, su concepto de la mujer, su concepto del hombre, su concepto de la vida y del mundo, todo eso es reflejo en él y exótico, todo lo encontramos disperso y palpitante en la literatura europea finisecular; Valencia solamente lo tradujo al español en bellas y pulidas palabras ${ }^{40}$.

El grupo de Los Nuevos, en su facción más vanguardista, se opone entonces al símbolo de esa consagración literaria de las reproducciones bellas o "viñetas" de la cultura señorial, como las denomina Gutiérrez Girardot, ahora completamente anacrónicas en la poesía

\footnotetext{
${ }^{40}$ Tejada 319. Las proclamas contestatarias de Tejada se remontan a Los Arquilókidas, grupo antecedente de Los Nuevos que lanzó primero las declaraciones fundacionales que éstos retomaron. Desde el deseo de "destruir el pasado a base de insultos y señalamientos, porque no creían posible "tratar a nuestra barbarie literaria con vocablos cariciosos" (Loaiza Cano 221), hasta la solicitud a la Academia Colombiana de la Lengua de la lista de sus miembros, con "objeto de conocer los nombres de los individuos que componen ese asilo de inválidos mentales, muchos de los cuales serán empalados y estrangulados sin misericordia" (Arquilókidas, citado en Loaiza Cano 225), este grupo, y Tejada como su figura más representativa, no puede desligarse de una visión amplia del desarrollo de la vanguardia en Colombia -del que también forma parte la revista Voces, del catalán Ramón Vinyes, amplia difundidora de las vanguardias europeas- pese a la muerte temprana de éste y el fin consiguiente de su "campaña iconoclasta".
} 
contemporánea. La crítica se genera, por lo tanto, dentro del contexto del desarrollo de la literatura del continente, en atención a sus implicaciones estéticas e ideológicas. Este es un aspecto clave, pues la vanguardia no se alza únicamente en contra de un estilo determinado de la creación artística, sino de la ideología en la que se moviliza el concepto global y tradicional del arte. La oposición es explícita en mayor o menor grado. En el caso de Tejada, el panfleto o la sátira están a disposición de su deseo de ruptura. Pero en otros, como De Greiff o Vidales, es la creación poética la que se presta para romper desde el ámbito estético la tradición en que está fundada. Es un error no reconocer en esta poesía la ruptura con la ideología de la sociedad dominante. La presunta independencia del ámbito estético respecto de los demás discursos de la sociedad moderna se ha quedado obsoleta en las declaraciones ya nostálgicas del arte por el arte. En el marco de una creación poética que responde desde el material artístico a las proclamas de Tejada, comprometida con el cambio de los parámetros estéticos y por lo tanto ideológicos de su época, es desacertado no considerar la dimensión política de esta renovación. La actitud contestataria en Tejada y la ruptura propiamente estética en De Greiff y Vidales -para Gutiérrez Girardot los únicos entre Los Nuevos que lograron poner en "tela de juicio" a la sociedad- se genera en una coyuntura histórica muy particular, y por eso sus implicaciones son relativas a su contexto social. En este panorama de la cuestión es posible aclarar los nexos que unen la vanguardia a la decadencia del modernismo ya consagrado en la sociedad tradicional y en consecuencia poco "modernizante”, en el que, no obstante, Gutiérrez Girardot encuentra las "condiciones de posibilidad" de aquella: "el modernismo de Valencia fue artificial y simplemente mimético (de ahí su trivialidad), porque la sociedad señorial que él encarnaba constituía el polo opuesto de la que había posibilitado en Latinoamérica la génesis del Modernismo" (Ensayos 82). La vanguardia en el continente y concretamente en De Greiff, como se ha dicho, no es una asimilación de modelos europeos sin relación alguna con el contexto histórico, sino la respuesta a una ideología en este caso enmarcada en el tiempo sin historia de la sociedad tradicional. En el estatismo de esa sociedad y de un modernismo que ha comulgado con los principios de dominación del régimen señorial, De Greiff introduce un elemento disociador aludido por Marie Estripeaut Bourjac: la negación de la estabilidad del tiempo detenido y la apuesta por una concepción de la poesía apoyada en la divagación y la 
indefinición, tanto del discurso que articula la realidad como del sujeto que se manifiesta en ese discurso.

La indefinición del sujeto poético respecto a su función social y la constitución de su propia individualidad es una constante en De Greiff. De aquí se derivan dos oposiciones: frente a la enunciación estable y segura de la literatura más tradicional, y frente al sujeto como entidad unívoca e indisoluble, presente todavía en la poesía finisecular de avanzada. Esta posición contradice la base epistemológica en que se sustenta la literatura anterior, y por esa misma vía, los diferentes discursos de legitimación de la cultura consagrada que gozan de enorme presencia, como hemos visto, en el ámbito de esa literatura. Se trata de atacar las bases ideológicas de la sociedad tradicional con una inversión la estructura discursiva que antes se ha prestado para esa legitimación, y del sujeto que configura y se configura a sí mismo en esa estructura. Estripeaut Bourjac ha analizado la oposición que desde el material artístico se genera hacia esa tradición lingüística del "ditirambo hiperbólico" e "hinchado" del que hablaba Lleras, o del "diluvio retórico más prolongado y caudaloso que haya soportado nunca pueblo alguno" del que hablaba Zalamea. Los centenaristas, adscritos a la cultura señorial y agraria de la "oligarquía de grandes terratenientes" a que alude Paz, son el órgano de propaganda y legitimación de esta cultura, y como ideólogos de lo establecido, intentan consolidar las bases del orden social que le da sentido a su existencia. Eso sugiere la autora en un planteamiento que retoma la opinión antes citada de Zalamea:

La agitada historia de finales del siglo XIX y principios del XX lleva al Centenario a representarse el futuro como vuelta inexorable al caos o como revolución. Para preservarse, esa generación escoge transformar su necesidad de permanencia en fijeza, lo que engendra el imaginario del tiempo inmutable o tiempo fijado. [...] De esta forma, la generación del Centenario detiene el curso de la historia, prefiere postergar las reformas sociales y económicas "y fomenta durante treinta años una casta señorial que no pasará del medio millón pero que se da el lujo de vivir de espaldas a los siete y medio millones restantes de colombianos”. (Estripeaut Bourjac 743-744)

La generación del Centenario representa el anhelo de permanencia de la cultura señorial a través de la imagen del tiempo inmutable, mientras Los Nuevos, en cabeza de los poetas, contradicen expresamente esa pretensión de inmovilidad, con una protesta estética que en 
consecuencia también es política ${ }^{41}$. Las formas de ruptura son variadas, pero se encaminan todas al cuestionamiento de las bases ideológicas que los centenaristas pretender fijar y consolidar. Así pues, en respuesta a la concepción del tiempo inmutable de la cultura señorial y a la protección del estatismo de su espacio vital, De Greiff, en concreto, opone sus imágenes de lo efímero, su metáfora del exiliado, sus ansias de inmensidad, de vagabundeo por los espacios ilimitados:

Como superación del esquema espacial del aislamiento y en respuesta al "espacio flotante" [estatismo de la sociedad señorial] y al "paraguas" [protección de Luis Vidales frente a ese espacio], León de Greiff elige la "inmensidad". Lo único importante son los viajes y el recorrido, vagabundeos sin meta precisa y en todas las direcciones posibles en que el poeta se representa como un ser sin casa ni hogar, obligado al exilio. (746)

La autora hace énfasis en el intento de Los Nuevos de destruir el espacio estático dominado por la cultura oficial de su época, a través de una multitud de referencias a nuevos modelos ideológicos que entran en conflicto con el orden señorial decimonónico. Precisamente aquí está el vínculo entre la ruptura institucional de la vanguardia hispanoamericana y la ruptura de la vanguardia europea: la impugnación de un modelo estético dominante que representa la prolongación ideológica del orden social establecido. Con base en el primer comunicado del grupo en su revista, Estripeaut Bourjac habla de la concepción de país que predomina en sus integrantes, como una suerte de "pudridero" en constante decadencia, dirigido por "la oligarquía de esa Colombia señorial y agraria [que] concibe al país como una gigantesca

\footnotetext{
${ }^{41}$ Estripeaut Bourjac se refiere a la "generación" de Los Nuevos para establecer un conflicto generacional con los centenaristas, representantes del antiguo orden. Sin embargo, estos últimos son más merecedores de esa categoría estudiada y definida por José Ortega y Gasset, debido a su mayor coherencia de pensamiento frente al contexto histórico de su tiempo. En efecto, si bien Los Nuevos, además de estar condicionados por unas mismas circunstancias históricas, están "unidos en torno a intereses literarios y evolucionando casi todos hacia lo político", no presentan en su totalidad una ideología o una actitud bien definida respecto a esas circunstancias históricas o a las posturas políticas que deberían adoptarse a partir de ellas, ni en consecuencia la "existencia de un comportamiento colectivo" (734). Las contradicciones entre los miembros de Los Nuevos, en este punto, son evidentes, como ya se ha dicho, y resulta dudoso agruparlos en la categoría a veces equívoca de "generación". Por ello, no se comparte aquí dicha categoría, para evitar el posible equívoco de identificarlos a todos, de modo erróneo, con una práctica artística de vanguardia, si bien su ideología respecto a la tradición es algo más coherente, al menos en su núcleo fundamental; por mucho, se privilegiará, al hablar genéricamente de Los Nuevos, a los autores de este núcleo que comparten esta ideología, o más en concreto una práctica artística coherente con ella, aunque teniendo presente dicha salvedad y justificando la referencia general a la "vanguardia" del grupo por la importancia que esa tendencia tuvo en su perfilamiento, tanto en su momento como en la perspectiva de la evolución de la literatura colombiana (al respecto, v. pág. 69, nota 38, en el presente trabajo). De todos modos, en un capítulo posterior se hará algunas precisiones respecto a la naturaleza de la vanguardia en Los Nuevos y en De Greiff en particular.
} 
finca a la que se debe dar la mejor administración" (742), y que debe ser purificado por medio de la renovación. Así lo indica en su cita de Lleras, cuando éste declara que "no hemos temido desvincularnos con el pasado para lanzarnos a las nuevas corrientes. Y sin raíces en nuestra historia patria salimos adelante buscando siempre un viento más, una forma nueva, una fórmula más exacta, siempre mirando adelante" (738). La protesta de Los Nuevos contra el modelo social y estético reinante se efectúa alrededor de las nociones de tiempo inmutable y espacio estático promovidos por la cultura señorial, mediante imágenes que rompen por completo esa visión estática del país, y que en De Greiff se presentan como referencias a la evanescencia, al vagabundeo, a la omnipresencia del instante efímero más que a la permanencia del pasado: "León de Greiff construye toda una constelación de símbolos alrededor de esa evanescencia expresada por la nube y el viento (que sintetizan tiempo y espacio) o por las aves [...]. El viento toma posesión de los espacios e impone el gozo del instante; las palabras se convierten en símbolos de lo transitorio y la poesía misma es efímera" (747-748). El panorama de la cultura estática y conservadora es cuestionado por este grupo de escritores y activistas en un gesto contestatario cuyo principal detonante es el deseo de renovación. En esta perspectiva, Los Nuevos forman parte de ese llamado a la revolución social y estética contra el orden institucional establecido, que es proclamado bajo una multitud heterogénea de rótulos pero que se agrupa en general dentro de lo que se ha dado en llamar vanguardias. Ahora bien, desde la perspectiva específicamente estética es preciso hacer una aclaración. Al observar la obra concreta de los poetas de Los Nuevos en su material artístico, se comprueba sin dificultad que, pese a que muchos comparten una postura de avanzada en un plano extraestético, sólo pocos pueden ser reconocidos como poetas vanguardistas, a raíz de la perduración de nociones tradicionales de la poesía en los demás. Más aún, como ya quedó dicho, en el grupo, además de poetas y escritores, hay una fuerte presencia de políticos o periodistas que contribuyeron a perfilar su ideología, pero cuya obra literaria o artística es nula. El calificativo de vanguardia, como categoría estética, no es del todo adecuado a un grupo de escritores y artistas con una ideología de avanzada que sin embargo no trasladan su protesta al tratamiento y configuración del material artístico. Una vez más, esta batalla debe ser librada desde el arte mismo si se pretende que éste tenga algo de avanzado. $\mathrm{Y}$ es aquí, en el material artístico mismo, donde se despliega el elemento que integra a De Greiff en las corrientes poéticas contemporáneas, a diferencia 
de muchos de sus compañeros de grupo: la desestabilización del lugar de enunciación a través de la ironía y el consiguiente descentramiento de la subjetividad lírica, en contra de las seguridades y los referentes demasiado inmóviles de un campo intelectual entregado al culto de la reproducción consagrada, de la "cultura de viñeta".

Desde el primer volumen de De Greiff se aprecia la multitud de perspectivas que integran su universo. La tematización constante de la poesía y de sí mismo como poeta, al modo de la autorreferencialidad postulada por Bürger, lo acerca a la reflexión sobre la naturaleza de su oficio y de la poesía en general de corrientes estéticas anteriores, como el simbolismo o el modernismo; pero su manera de representarse la poesía dista mucho del tono de seriedad inexcusable o grandilocuente que en muchas ocasiones presenta este tipo de reflexión antes del siglo XX, vinculada a preocupaciones metafísicas en la mayor parte del romanticismo o al culto religioso del símbolo poético bajo el concepto de las correspondencias en la poesía finisecular. Si bien hunde sus raíces en el distanciamiento crítico del poeta frente a la intensidad del sentimiento que pretende articular en su expresión -ya anunciado por el concepto de la ironía romántica en F. Schlegel-, la poetización sobre la poesía y el arte en De Greiff se basa en una actitud del todo distinta y con ciertas implicaciones respecto a la función social de la poesía, que la desvincula por completo del concepto elevado de ella misma, de naturaleza sagrada cuando se la asociaba con algo sobrehumano, o de carácter contestatario cuando se proclamaba su independencia de la sociedad. En este caso, la autorreferencialidad está mediada por el conflicto entre la entrega total al oficio de la poesía y la conciencia de su progresivo desprestigio en la sociedad. A esto se debe que el poeta ya no sea el sacerdote que oficia la comunión entre el hombre y la naturaleza, como en tiempos de Hölderlin, sino sólo un vagabundo cuyas palabras, más que una revelación, son un delirio. En De Greiff, este delirio, relacionado con el deambular del vagabundo ebrio, es la base de la divagación, indisoluble del discurrir sin sentido del lenguaje:

Y mi sér lejos, en un vago

Soñar y soñar, por la clave

De signos arduos: no se sabe

Dónde mi mente vá...Divago... (Obras 132) 
Este divagar a través del delirio es el principio de autodefinición del poeta y el catalizador de sus emociones. El "ensueño ilusorio", "incoherente divagar", "fantasía disparatada de mi espíritu singular" en el poema "Divagación nocturna" (83). El tema del "Laude sencillo del amor armonioso, del retorno y del són cariciante":

(Caminante poeta

Trovero trashumante,

Hollador de las múltiples sendas

De la vida y del sueño,

Claudicante poeta,

Vagabundo viajero,

Trovero trashumante...;

$\mathrm{Y}$ tras decir vocablos recónditos

Y fórmulas arcanas

Y el absurdo poema;

Tras decir los ritmos malévolos

Y la anómala gesta

Donde alternan locuras y místicos

Cánticos, y la aventura y la bohemia;

Tras vivir al azar de las rutas

Psíquicas y sensorias [...] (152)

El divagar se manifiesta entonces a través del vagabundeo y del delirio. Vagabundo y loco: "Así mi vida discurre sin rumbo" (151). Son éstas las dos prolongaciones de una voluntad que se separa del estar o del decir convencional como negación de la tradición intelectual establecida. El poema se hace caracterización del propio poeta, "trovero trashumante" de "vocablos recónditos", "fórmulas arcanas" y "absurdo poema”, entregado a los "cánticos, y la aventura y la bohemia". El poema es el lugar de la vida incierta del poeta: "De resto viaja, indómita, -mi vida- al azar. Al azar! / ¿Qué rumbo? -Todos. Ninguno: La Rosa de los Vientos!" (201). En esta caracterización de sí mismo, cifrada en la imagen veleidosa de la Rosa de los Vientos, la vida azarosa de la divagación no puede separarse de la creación artística. En la intuición estética, arte y vida son una sola cosa, a despecho de la proclama de autonomía radical de consignas como el arte por el arte. El poeta, "trovador lunario" (153) donde se conjuga lo verbal, lo trashumante y lo lunático, "discurre" a través de sus 
días y de sus versos, bajo el signo del delirio y el sinsentido, en apariencia factores disociadores de un destino u objetivo concreto, pero en realidad el único destino y objetivo de un estar y un decir construidos desde la divagación. La evidencia de este reconocimiento es clara en la "Balada egótica, en tono teatral":

Yo soy estrafalario y soy abstruso;

Soy altanero y soy sencillo, y llevo

-Para reír- un gesto antiguo y nuevo

De Diógenes al uso.

Pierrot! Juglar! -Payaso de mis penas...,

Bajo el azur de universales climas

Lloro la carcajada de mis rimas

Sarcásticas y amenas!

Yo estoy loco. Estoy loco! Triste, irónico,

Pobre mimo!- Quijote de tinglado!

Muñeco de un guignol disparatado!

Coplero gris y afónico!

Desdén. Risas. Si todo es falso... ¡todo!

Todo verdad, todo existe y no existe,

Yo sólo sé que voy como un beodo

De beber vino triste! (Obras 40-41)

La esencia divagadora del ser, como negación de la cultura estática tradicional, es inseparable de su articulación por medio de la ironía, con la que se intensifica el distanciamiento respecto al convencimiento grandilocuente del valor social de la poesía. Igual que muchos otros, este poema sintetiza las inquietudes fundamentales del poeta en lo que se refiere a la apariencia social y la función de quien ejerce su oficio. A través de una visión irónica, se representa a sí mismo como la parodia de un poeta que no recorre el "azur de universales climas" sino para "llorar la carcajada de mis rimas". La conciencia de que todo y nada son lo mismo, de que "todo existe y no existe", atraviesa la incertidumbre de quien sin embargo no cede en la expresión de su propio sarcasmo. Ser poeta y expresar su poesía: es la imagen del "payaso de mis penas" que entona la burla de sí mismo. La ironía 
es lo suficientemente fuerte como para destruir toda pretensión de grandeza, pero también es la única expresión posible de la poesía. Es lo que indica Jiménez Panesso cuando dice que "sólo disfrazado de bufón puede el poeta decir sus verdades, de manera indirecta, a un mundo que ya no acepta sino la prosa. [De Greiff] llevó hasta sus últimas implicaciones la indicación de Laforgue y aceptó la arlequinada, la pirueta cómica, el cinismo, como formas apropiadas para mantener viva la seriedad de la poesía” (Antología 34). En una especie de farsa, el poeta mismo lo confirma: “-¿Esa risa befante, y este afán bufonesco? -Seriedad abomino. - ¿Dejar el canto y adoptar la cómica clownería? -Platitud abomino. [...] - ¿Dejar el canto y adoptar la cómica clown-bufo-pitre-gabe-juglaría? [...] ¡Oh bufón! ¡Oh clown! ¡Oh pitre! (Nova 33). De la noción del poeta como un sacerdote oficiante de los misterios de la existencia, a la manera simbolista, se ha llegado a la visión irónica de un vagabundo ebrio que delira sin sentido, algo así como un "poetilla lelo tras mentecato y loco o bobiloco" (62). Así ocurre en el "Poema equívoco del juglar ebrio: Sonata latebrante urdida en antiguo y en nuevo":

\author{
Por ahí viene el Juglar Ebrio \\ Danzando y rïendo. \\ Por ahí viene cantando el truculento \\ Himno de la alegría y la locura y el misterio... \\ Con voz de irónico Sileno \\ Viene cantando... Por ahí viene diciendo versos \\ Droláticos y heréticos, \\ Desnivelados y asimétricos, \\ Disparatados e inconexos. \\ Por ahí viene cantando su trémulo \\ Miserere, su lúgubre nenia, su treno \\ Funéreo. \\ Por ahí viene rïendo... \\ Cantando viene... ¡Silencio!
}

Que viene cantando y rïendo y danzando; que viene llorando el trovero! (Obras 183)

La ironía funciona en distintos niveles. En su obra, escrita con abundancia en interminables "libracos, mamotretos, infolios y papeles" (24), el poeta prolifera en su expresividad, acudiendo incluso a arcaísmos que reinventa y alterna con audaces neologismos, y a la vez 
establece una distancia crítica al representar sarcásticamente la carencia de valor de esa expresión. Toda su expresión se ve impugnada por él mismo. Canta sus versos con fluidez, pero insiste en que son "droláticos y heréticos, desnivelados y asimétricos, disparatados e inconexos", y siempre expresados en el contexto del vagabundeo azaroso y sin destino que caracteriza sus elocuentes delirios. A esto se refiere el "Pensamiento pobre":

Vate vagabundo

Complejo y trivial!

Con el Bien y el Mal

Urdo juglarías!

Penas y alegrías

Son para mi verso

Motivo perverso

De gayo dezir,

De triste reír

Y de alegre llanto!

Termino mi canto:

Pensamiento pobre

-Monedas de cobre-

Que de oro me finge

La irónica esfinge

Que en mí se recata...

Monedas de plata...

(No serán de plomo?...)

Muy agudo o romo

Doy fin a mi verso

Tortuoso y disperso...

¡Si así se divierte

Mi sarcasmo!... ¡Nada!:

Señora la muerte,

Fría, arrebujada,

De aqueste trajín

Me acecha a la fin! (10-11) 
En la "complejidad trivial" encontramos la contradicción que enmarca la expresión del poeta. El pensamiento pobre es sólo moneda de cobre que finge ser de oro. ¿O moneda de oro que pretende ser de cobre? En este juego de contraposiciones irónicas no sabemos qué opción elegir, ni siquiera si hay sólo una opción, debido a que todo, poetización sin tregua y conciencia del elemento burlesco, expresión elocuente y relatividad delirante, tiene cabida en esta poesía de múltiples tonos:

Pues yo dije que el hombre

Debe odiar a las hembras,

A las plantas, las rocas,

Las aves y las selvas:

O amarlas;

Que debe ser narciso

De sus propias miserias,

De sus vicios, virtudes,

Fealdades y bellezas:

O no serlo;

Que debe huir del vulgo

Como de impía fiera

Que devora las rosas

Del Jardín de Quimera:

O no huirlo;

Que debe amar al Búho,

-Signo de la sapiencia-

Al viejo Búho, hermano

De la locura gélida:

O temerlo; (22-23)

La disyuntiva en sí misma cuestiona las seguridades respecto a la conducta del hombre en la vida. Pero este hombre es también -y sobre todo- el poeta, propenso a la exaltación emocional de la naturaleza, puesto en el dilema sobre la cercanía o la lejanía del "vulgo", 
dividido entre su amor por la "sapiencia" y su proximidad a la "locura gélida". Y sobre todo, implacable narcisista de sus glorias y miserias: la autorreferencialidad no omite los escarnios burlescos, más recurrentes que los elogios, casi inexistentes, considerando que sólo ellos pueden, en palabras de Jiménez Panesso, "mantener viva la seriedad de la poesía”. En una época en que el arte ya se ha visto desplazado de ese pedestal sagrado que se construyó para sí mismo a lo largo de siglos, merced a la nueva ideología positivista que acompaña la progresiva instauración de la burguesía moderna y a la autocrítica de sus pretensiones finiseculares ya demasiado retóricas, sólo la ironía permite escapar al riesgo del anacronismo o la redundancia en una autosuficiencia sin fundamento real. La expresión se escinde entre la necesidad de la poesía y su contingencia en el contexto social. Una vez más, verdad y falsedad se nivelan, "todo existe y no existe", la disyuntiva eterna de lo absoluto y lo relativo desdibuja la unicidad del sujeto en permanente escisión. El poema continúa:

\author{
Que ha de ceñir su frente \\ De tibia enredadera \\ -Pues que el pensar constante \\ La desangra y afiebra...-: \\ O de espinas; \\ Y vivirá mirando \\ Con mirada serena \\ El horizonte oscuro, \\ Ruta de la Quimera, \\ Senda de lo ignorado, \\ Camino de la eterna \\ Tranquilidad, del valle \\ De la suma inconsciencia... \\ Amén.- \\ (O viceversa...!) (23)
}

En su estudio sobre la ironía como instancia de inadecuación del individuo en el marco de sus propias contradicciones, Juan Manuel Cuartas describe la labor de deconstrucción del 
sujeto a la que se ve abocada la expresión poética en De Greiff. La concepción elevada de la poesía se ve impugnada gracias a la exposición del sujeto en todos sus ámbitos, desde la raíz de su verdad y su falsedad, desde la posibilidad y la imposibilidad de volcar su ser en el lenguaje:

La ironía que orienta la escritura de León de Greiff no comporta, como veremos, un concepto elevado de la poesía; fundamento de la ironía es el lenguaje, pero el lenguaje no es instrumento suficiente para nombrar y relacionar; allí donde nace la doble posibilidad de "verdad" y de "falsedad" del Ser a través del lenguaje, allí nace propiamente la ironía. La ironía nos aferra, más que la referencialidad pretendida por la palabra, al individuo que se debate en ella, a su totalización en la escritura. La ironía propone en la poesía de León de Greiff una tentativa de superación, de exposición de su Yo sensible y duradero. Empero, De Greiff no consigue como poeta más que su desbordamiento en la escritura, desbordamiento de la ironía que subyuga la consistencia del Yo. (Cuartas, “León de Greiff” 112)

La existencia contradictoria y su expresión fragmentaria se imbrican en una poesía que se debate en los límites del lenguaje en una época ya próxima a la plena explosión de las vanguardias. La ironía desdibuja por completo la individuación y la somete a las vicisitudes del lenguaje: la expresión es la condición de la existencia y no al contrario, pero su ironía destructora escarnece la unidad de la poesía y del sujeto de enunciación:

El mecanismo efectivo de la ironía consiste en De Greiff en la posibilidad de señalar lo que hay de falso o de unilateral en la tesis en la que finge participar; el fondo reside en el Yo y en su acto de "decir”; León de Greiff es poeta, y como tal, "violenta perorata” es su poesía. La ironía es destructora, choca violentamente la sustancia del Yo creada en la escritura, porque en el fondo su vinculación más íntima es la tragedia; la ironía a este respecto no es simple artificio, por el contrario, es confrontación del individuo creador con el lenguaje o con las cosas sensibles por él designadas. Querer alabar el oficio de poeta dando rienda suelta a la escritura repercute de manera ambivalente y trágica en la burla del poeta, un poeta que procede, en el caso que analizamos, de León de Greiff como sujeto, pero que se disemina en otros tantos poetas: "Y es mi existencia trunca, / porque a todo respóndeme con voz dura y letal / un ser oculto y trágico que dice y dice: nunca...!”. (113-114)

Como afirma el autor, la ironía no es un procedimiento más en la poesía de De Greiff; por el contrario, es la materia misma de su expresión. Sólo ella preserva la abundancia de su lenguaje de las altisonancias decimonónicas de la poesía autorreferencial. La retórica de la autosuficiencia disminuye en la medida que el individuo se fragmenta en la escritura y la 
poesía se revela como el espacio conflictivo de la dispersión o la reconstrucción de esa fragmentación:

La ironía se formula cuando se considera que el sujeto participa tanto de la convicción idealista, a la que ha llegado de manera poco crítica, como del interés material; podemos acceder en este sentido a un concepto de la ironía en León de Greiff según el cual la ironía descompone el Yo en la obra, es su discontinuidad y su escritura al mismo tiempo. La ironía arredra la individuación del autor en la escritura, representando al mismo tiempo tanto su humanismo inalterable como su aprisionamiento en las redes del tedio y la melancolía. (114)

Ahora bien, el autor cree advertir una "encrucijada" en la persistencia de la ironía, que confinaría a De Greiff en la "descontextualización con la realidad” de una "poesía que tiende hacia dentro de su lenguaje, substrayéndose a la percepción crítica de la realidad conflictiva colombiana o latinoamericana que le tocó vivir al poeta" (133). Más allá de las diferentes concepciones sobre la relación entre arte y sociedad, es evidente que hasta la proclama radical de la autonomía del arte entraña una percepción concreta de la realidad social y de la función del arte en ese contexto. Sin necesidad de aducir los argumentos claramente postulados en sentido contrario por Estripeaut Bourjac, en su tesis sobre la actividad contestataria de De Greiff y Los Nuevos frente a una realidad estética y política de carácter señorial e inmutable, es claro que la poética de De Greiff remite a un contexto artístico donde su lenguaje fragmentado por la ironía y su concepción desacralizada de la poesía adquiere sentido dentro de una totalidad social, con base en las diferentes relaciones ideológicas que establece respecto a ella. Con el propósito de enfocarnos en la relación de oposición que genera la obra de De Greiff dentro de este contexto, según los argumentos ya examinados sobre algunos de sus elementos estilísticos más avanzados, es necesario enmarcarla en otra oposición mucho más específica, definida por el contraste entre su concepción descentrada de la poesía y el lenguaje institucionalizado por la tradición literaria anterior a esa concepción. Bajo esta perspectiva y con toda propiedad, es posible enmarcar el lenguaje del poeta en las inquietudes literarias más contemporáneas de su época, vinculadas a diferentes tendencias vanguardistas que se propusieron distanciarse de 
las instituciones artísticas ya consolidadas y renovar desde su misma estructura los lenguajes artísticos y su función dentro de la totalidad de la sociedad ${ }^{42}$.

Los inicios de la vanguardia en nuestro continente, al igual que en el contexto europeo y como sucede con cualquier tendencia artística en etapa de consolidación, no exhiben los rasgos uniformes de un movimiento único, cual si hubiesen sido previamente concertados por quienes después fueron considerados sus precursores. Cada uno de éstos se enmarca en la nueva tendencia con procedimientos distintos y en ocasiones contradictorios con otros aspectos de su poética particular. La vanguardia no nace de sí misma. Su origen no se encuentra por completo en la conciencia del desarrollo de la institución artística a partir de su última etapa simbolista de "diferenciación", como podría deducirse de algunas explicaciones de Bürger -cuestionadas hasta cierto punto por Hal Foster en lo que se refiere a una pretendida generación espontánea de los nuevos movimientos--, sino que asume su forma progresivamente gracias a las rupturas estilísticas contra el arte decimonónico que se alternan de modo constante pero discontinuo a lo largo y ancho de prácticas artísticas más o menos contemporáneas. La cristalización de una tendencia contradictoria respecto a las concepciones y las prácticas de la institución artística contribuye eficazmente a proyectar la existencia de esa misma institucionalidad, al endosarle los calificativos de "arte burgués" o de "sistema de las artes". Por lo demás, y dejando de lado la cuestión sobre la perduración de la "institucionalidad" del arte después de las vanguardias, estas tendencias comienzan a manifestarse en la contradicción de elementos tradicionales y novedosos dentro de las obras que ya se encuentran al borde de una estética diferente, y así mismo en el conjunto del arte

\footnotetext{
${ }^{42}$ Con esta definición no se pretende asegurar que la poesía de De Greiff, en su conjunto, forma parte indisoluble de los movimientos vanguardistas, ni mucho menos que debe ser concebida enteramente en el marco de estas nuevas corrientes, pues es indudable que muchos de sus rasgos estilísticos, con todo y ser una impugnación marcadamente irónica de algunas concepciones modernistas, no llegan a romper del todo los moldes tradicionales de la expresión. Simplemente, se trata de contextualizar en estas nuevas tendencias algunos aspectos de su obra, claramente relacionados con actitudes y procedimientos vanguardistas, que no tienen cabida dentro de una concepción del modernismo literario entendido en su más común acepción, es decir, en referencia a la literatura finisecular de derivación simbolista que comporta los últimos y más avanzados rasgos de una estética aún decimonónica. En efecto, aspectos como la ironía escarnecedora hacia la poesía misma, hasta el punto de la desestabilización del lugar de la enunciación o el descentramiento del sujeto que esto conlleva, no son de ninguna manera asimilables al concepto elevado de la poesía como expresión de un sujeto indivisible propio del modernismo, ni siquiera en la ampliación de esta categoría por parte de alguna crítica, no siempre bien recibida y más bien objetada desde diversas posturas teóricas. En este caso, es evidente la pertenencia de los componentes mencionados en la obra de De Greiff a una poética de avanzada, y como tal, deben ser examinados en el marco estético de los inicios de la vanguardia, a donde pertenecen por derecho propio.
} 
institucionalizado hasta el momento en un contexto determinado. Aquí llegamos a la necesidad de distinguir los rasgos definitorios de ese contexto con el fin de evidenciar el carácter de la protesta que los primeros procedimientos vanguardistas plantean.

En su ensayo sobre uno de los escenarios iniciales de los debates vanguardistas en la Argentina, la revista literaria Martín Fierro, Beatriz Sarlo insiste en la necesidad de determinar ese contexto como paso previo a la elucidación crítica de la ruptura establecida, considerando que es ahí donde reside la clave de la vanguardia que se propone examinar, en contraste con la búsqueda de la radicalidad contestataria, que pese a ser el aspecto más característico de la vanguardia europea, siempre se enmarca un sistema de relaciones con el campo artístico de su época:

[...] ¿dónde buscar la verdad de la vanguardia argentina? Es indispensable referirla al sistema literario y al espacio socio-cultural respecto del cual rompe. La radicalidad de la vanguardia puede considerarse su rasgo europeo más constante (extendiéndose incluso a lo específicamente político: vanguardias rusa, alemana, surrealismo francés), pero siempre es una función relativa al campo intelectual que la vanguardia encuentra constituido y consagrado. La ruptura aparece vinculada con la extensión y desarrollo del campo intelectual, cuya legalidad la vanguardia niega. La consolidación y el prestigio de la tradición cultural crean, paradójicamente, la fuerza de su vanguardia. [...] el campo intelectual genera su vanguardia y las formas de la ruptura entran en sistema con las modalidades de la vida literaria preexistentes. El cambio ideológico-estético no se produce en un vacío social, sino que, por el contrario, encuentra en las formas sociales de la producción literaria sus condiciones de realización. (Sarlo 212-213)

Este planteamiento nos sitúa ante un panorama amplio de la ruptura literaria vanguardista y nos permite indagar en los orígenes de una tendencia que en Hispanoamérica no se construye sobre la misma base ideológica que la proclamada por su correspondiente europea. En el contexto de nuestros países es imprescindible establecer una referencia al movimiento común del modernismo hispanoamericano de corte progresista, y a la estética más bien conservadora de las diferentes generaciones del Centenario que optaron por la alternativa del casticismo formal y la reconstrucción y consolidación de las instituciones sociales en que se fundaban las identidades nacionales. Por esta razón, el campo intelectual al que hace referencia la autora es bastante complejo, si bien exhibe desde un comienzo 
estas dos vertientes ideológicas básicas. Los conatos de la vanguardia latinoamericana de las primeras décadas del siglo se derivan principalmente de la estética modernista, más acorde con inquietudes auténticamente contemporáneas que la generación del Centenario; pero establecen su ruptura frente a ese modernismo ya plenamente institucionalizado, lo mismo que frente al ambiente social e intelectual de restauración encarnado y promovido por los centenaristas. La oposición de la primera vanguardia, en consecuencia, se produce tanto en el contexto estético como en el contexto social. No es correcta la tesis de Cuartas sobre el ensimismamiento autorreferencial en el que se replegaría la obra de De Greiff, pues la ironía de su lenguaje contra la individuación poética y su distanciamiento de un orden social y estético fundado en la inmovilidad o la vuelta al pasado son la proclamación más elocuente de la ruptura operada por su poesía. En torno a De Greiff, es incuestionable el planteamiento de Gutiérrez Girardot sobre los inicios de la vanguardia no como la simple imitación de modelos europeos sino como el "desarrollo dialéctico del modernismo literario y de la modernización social". La ruptura es doblemente controversial, puesto que genera problemáticas no sólo en el contexto interno de la institución artística, sino incluso más allá de ese carácter propiamente estético de la "crítica al sistema de las artes" o "autocrítica del arte” a la que se refiere Bürger. La percepción de Sarlo en este sentido es esclarecedora:

La ruptura de la vanguardia, lejos de ser específicamente estética, y aun cuando reclame esa
especificidad, afecta al conjunto de las relaciones intelectuales: las instituciones del campo intelectual
y las funciones socialmente aceptadas de sus actores. En suma, todas las modalidades de la
organización material e ideológica de la producción artística son afectadas por la vanguardia. Pero,
antes de ser afectadas, la hacen posible. ¿Cuáles son las condiciones de surgimiento de la vanguardia?
Precisamente la existencia más o menos desarrollada de un espacio cultural cuyas formas e ideología la
vanguardia va a poner en cuestión. La trama del campo intelectual presupone y anuncia su vanguardia. (Sarlo 213)

Desde esta doble perspectiva estética e intelectual empieza a ser comprensible la amplitud de la ruptura que algunos componentes de la obra de De Greiff generan con respecto a la tradición literaria de su tiempo. En su poesía se incuba el germen de la protesta frente a un campo intelectual donde incluso el modernismo es ahora una novedad ya institucionalizada. El prestigio alcanzado por los poetas de la última etapa modernista, anterior a lo que algunos autores como Federico de Onís han llamado "crítica postmodernista”, como Rubén 
Darío o Guillermo Valencia, es la prueba más fehaciente de esa institucionalización. Frente a ese orden intelectual ya establecido, De Greiff opone, como señala Estripeaut Bourjac, la huida a través de la inmensidad, el vagabundeo sin tregua sobre caminos al azar, las imágenes de lo efímero y lo evanescente, la "violenta perorata" que delira en verbosidades abundantes, la tragicomedia del Narciso "de sus propias miserias, / de sus vicios, virtudes, / fealdades y bellezas". En fin, el "permanente decir de versos por todas / las estaciones, climas, latitudes" (De Greiff, Obras 50), puesto que el vagabundeo al azar se sustenta en el discurrir del lenguaje. La proclama rebelde de libertad retorna una y otra vez, como en la "Balada del abominario, diatriba imprecante y oratoria":

Dejadnos locos a los locos

Soñando en vaga nimiedad:

En lo impreciso y lo quimérico,

En lo ayuno de realidad,

En las empresas que fracasan,

En los ritmos sin claridad

Donde dialogan locas almas

Ebrias de personalidad,

Enamoradas de sus vicios,

De su acritud, de su maldad!

Adversarios de lo manido,

De lo obsoleto, de lo usual,

De las sonantes academias,

De los casos de actualidad,

De las virtudes de precepto,

De los juicios de autoridad...!

Y que desdeñan vuestros rostros

Estucados de seriedad,

Revestidos de suficiencia,

Insufribles de necedad,

Ventripotentes apopléticos,

Amarillosos de vanidad,

Canijos, lánguidos, obesos,

Glabros, velludos... ¡variedad

Infinita de formas y modos 
Para idéntica mentalidad...!

Monopolistas de 'lo bello',

Incapaces de interceptar

Una emoción desemejante

A la emoción que es del ritual! (37-38)

La admonición a los "monopolistas de lo bello" es mucho más que sólo una proclama de distanciamiento respecto a la antigua estética: se trata de una revuelta que expulsa al limbo a todos esos "figurines" que integran la cultura oficial de la consagración, en el mandato del "envío" final:

Entes raquíticos, estólidos,

Idos al Limbo, presto, andad!

Andad al Limbo figurines,

Turba de lo sacramental,

Inocuos y zurdos y vacuos,

Solemnes y zafios y tal...!:

Mientras nosotros vamos, lentos,

A la Quimérica Ciudad,

Entre coros de befas y burlas

De la vetusta humanidad...! (38)

La imprecación del abominario es lanzada desde la postura de un "nosotros" que impugna la "turba de lo sacramental", con todas las implicaciones de sociedad cerril, institucionalidad consagrada y tradicionalismo que este calificativo encierra. Si bien la "Quimérica Ciudad" parece situarse en la geografía del exotismo finisecular que en el siglo XIX se prolonga hasta el modernismo, no corresponde del todo a la actitud escapista de los ensueños de tiempos antiguos, pues se trata de un destino que al situarse precisamente en el ahora de las inquietudes por lo nuevo, se alcanza sólo entre las "befas y burlas" de la "vetusta humanidad". El rumbo es incierto, sin duda, porque la "Quimérica Ciudad" parece ser la tierra prometida y esquiva que persigue el poeta a lo largo de sus interminables vagabundeos; pero es evidente que se encuentra a distancias más que considerables de esa institución literaria que a un mismo tiempo es evadida y acometida por él. Por otra parte, su 
poesía no se realiza en el espacio sagrado de la "Quimérica Ciudad", sino precisamente en la marcha decidida y sin precedentes literarios que lo separa de ella. La escritura en De Greiff es justamente la expresión de sus vagabundeos al azar, donde el fin en sí mismo no es tan importante como la condición errante a que el poeta se somete a sí mismo: "Y yo, oh Baruch! voy a viajar, si ignoro / para dónde y por qué. Viajar sin ruta / ni derrota y sin rumbo tras sin meta [...]" (671-672). Es sólo en el viaje, al paso lento del trovero trashumante, donde se escriben sus versos:

\author{
Por el camino \\ Por el sendero \\ Viene el peregrino. \\ Por el sendero \\ Con paso tardo \\ Marca sus huellas el viajero. \\ Con paso tardo \\ Marca sus huellas \\ El bardo. (172)
}

La reivindicación del viaje en su calidad de tránsito hace que la condición de viajero predomine sobre el anhelo de alcanzar un destino específico. Lejos de la explicitación de un rumbo que marque su "propósito" y su fin, el desplazamiento se convierte en la ocasión de la escritura, un discurrir de divagación que va plasmando letras en el camino y que prolonga así, en función de la creación misma, el eterno trashumar del trovero vagabundo. Así, la XIV de las Prosas de Gaspar inicia: "Bien que no ha de ser nada interesantísimo, ni interesante, mondo, quiero hacer el relato de mis últimas andanzas, para regocijo y mofa, o mofa, mondo, de futuros seres descabalados y excéntricos" (284); y después de dos páginas de cometarios enrevesados y referencias a todo tipo de "farsas, tergiversaciones y facecias ferales", o "juegos de invención y fantasía", finaliza: "Después de tanta palabrería, advierto que no he iniciado el recuento de mis andanzas y aventuras, lo cual -conjeturo- no ha de torcer el curso de los astros..." (285). Naturalmente, las "andanzas y aventuras" no se cuentan. O se cuentan, pero de manera indirecta, pues el texto entero es una larga serie de “andanzas y aventuras" que, bajo el pretexto de ser la presentación de otras, resultan ser la 
presentación irónica de ellas mismas. Es hacia ese "trashumar del trovero vagabundo" en el ámbito del discurrir de la palabra, al que apunta también "Balada del mar no visto, ritmada en versos diversos":

Hermano de las nubes

Yo soy.

Hermano de las nubes,

De las errantes nubes, de las ilusas del espacio:

Vagarosos navíos

Que empujan acres soplos anónimos y fríos,

Que impelen recios ímpetus voltarios y sombríos!

Viajero de las noches

Yo soy.

Viajero de las noches embriagadoras; nauta

De sus golfos ilímites,

De sus golfos ilímites, delirantes, vacíos,

-Vacíos de infinito... vacíos, -Dócil nauta

Yo soy,

Y mis soñares derrotados navíos...

Derrotados navíos, rumbos ignotos, antros

De piratas... jel mar!... (54-55)

Como el viaje y el ensueño, la poesía es el discurrir al azar que encuentra en la expresión misma, más allá del hipotético arribo al referente expresado o recuento de sus "andanzas y aventuras”, su razón de ser. En su simple movimiento está la base de la creación: “Mira: ¡el azar cómo inventa / sin darse cuenta!” (446). La poesía es un desvarío sin rumbo evidente: "Vagar y divagar y discurrir sin ruta y sin sendero / y sin meta [...]" (493). A esto apunta su caracterización en De Greiff, por parte de Estripeaut Bourjac, como "una constelación de símbolos alrededor de esa evanescencia expresada por la nube y el viento", en donde "las palabras se convierten en símbolos de lo transitorio y la poesía misma es efímera". Y no sólo la poesía, cabe aclarar, sino también el poeta: "Yo soy el Viento. / Alígero discurro / [...] / Yo soy el Viento. / Impávido discurro / [...] / Yo soy el Viento. / Y al azar discurro” (322). Esto es claro en "Fantasías de nubes al viento", más exactamente en la evocación de esas voces extinguidas cuya fugacidad es captada en el momento de su tránsito al olvido: 
Adiós, adiós, que se fueron,

Fantasías, y al viento y al mar!

"Que se fugaron, adiós! adiós todas ellas!"

Ficciones! Fantasías de nubes al viento

Vagabundo!

Fantasías al viento lento,

Tardo, -y aventurero y errabundo!

Descaecidas, abolidas fábulas!

Fantasías de nébulas al viento

-Trémulas de emoción,

Grávidas de pensamiento,

Leves, inútiles, errátiles, como su ambición,

$\mathrm{Y}$ fugitivas como su contento!

Fantasías al viento, fantasías de nubes al viento

Indómito, violento! (256)

La fugacidad es en sí misma el objeto de la poesía. Su condición inabarcable no disminuye su fuerza expresiva. Todo lo contrario. Es igual que el viento: errátil e intangible, pero "indómito, violento". Una canción que "nació en el Viento y se finó en el Viento" (309), como esas "Favilas" que en De Greiff adquieren el estatuto de forma poética, y cuyo cuerpo resplandece antes de desaparecer para siempre en la nada:

Era la Poesía como la luz del viento

Cuando discurre -sordo-, cuando divaga -ciega-.

Símbolo puro del infinito dentro del momento

Y de lo efímero que dura y que perdura y que se vá y que nunca llega. (498)

Lo efímero es la razón última de la creación poética, lo que dura y perdura, lo que se va y nunca llega, es decir, la errancia misma, ésta sí de carácter infinito y eternamente anhelada: 
"Y erigir a lo efímero, de lo efímero, con lo efímero, perenne monumento" (697). La poesía es la irradiación momentánea de aquello que, llegando, ya se va: "No te me vas que apenas te me llegas, / leve ilusión de ensueño, densa, intensa flor viva" (516). La fugacidad es la única existencia concebible, y su paralelo en la poesía es el desvarío, el discurrir en torno de sí mismo, al azar:

Como una nube, así fue transitorio.

Como una nube, así fue duradero,

Como una nube, como una nube al transitorio

Viento fugaz:

(Viajero

Yo también soy, de sino emigratorio,

También yo soy tornátil, de esencia azas fungible,

Como la nube que llega y luce y cruza y nada más...) (323)

La fusión de identidades entre el poeta, la poesía, el viento y las nubes es evidente, en unas correspondencias que ya no fijan una experiencia sobre símbolos cultuales capaces de revertir momentáneamente la crisis de la modernidad, en el sentido que les adjudicaba Benjamin, sino que, por el contrario, ahondan en esa crisis al cambiar lo momentáneamente seguro por una simbología de lo eternamente inestable:

Veces veía vagueante viento

Las nubes naves en sus alas olas

Llevarse, y resonantes caracolas

Tañer, -ululador en su lamento-. (506)

El viento, como lo efímero, parece ser la metáfora de todo cuanto existe en la experiencia del poeta. Es casi el alma de su expresividad, que perdurará después de la muerte de ésta, pues las palabras, hechas de viento, como "favilas hechas Coros" (720), terminarán por disolverse en la esencia de la que provienen: "Cuándo será que el viento me barra y borre 
con su alarido?" (701). Hasta que esas palabras, y por tanto la subjetividad del poeta, sean barridas y borradas, la divagación implícita en esta metáfora y el delirio que ello comporta son omnipresentes:

Para echarlo a volar y a danzar, a danzar y girar,

Para echarlo a danzar,

A danzar y bogar y vagar,

A danzar y volar, parabolar, cabriolar y revolar

Con el viento,

Con el viento -que es viento para el viento,

Por el viento, en el viento...- (697)

En opinión de Jiménez Panesso, para De Greiff "la poesía es un absoluto. No renuncia a ella, versifica obsesivamente hasta la vejez, y cuando siente que se repite y ya no hay nada qué decir, pues todo es fárrago, no se detiene: 'Hay que mover las aspas del molino / por más que falte el grano de moler" (Antología 34-35). O bien, hacer rugir el viento "con su alarido" por más que falte el sentido de la palabra que viaja en él:

Aquí no llega sino la Voz

Del Viento.

Y canta.

Canción del Viento, canción del Viento!

Aquí no llega sino la Voz

Del Viento,

La Voz del Viento! (Obras 329)

Pero esta poesía como absoluto - viento sin palabras, aspas de molino sin grano- no es la poesía en su noción elevada, que en el simbolismo busca restituir con las correspondencias las bases metafísicas de un universo secularizado, sino el acto de poetizar sin descanso con la inocuidad y el sinsentido que esto pueda significar para una sociedad donde la novedad es una disonancia. "Canción sin tón ni són” (Nova 79) cuyo vacío y cuya divagación, lejos de ser una razón para el silencio, son la razón misma del canto: 


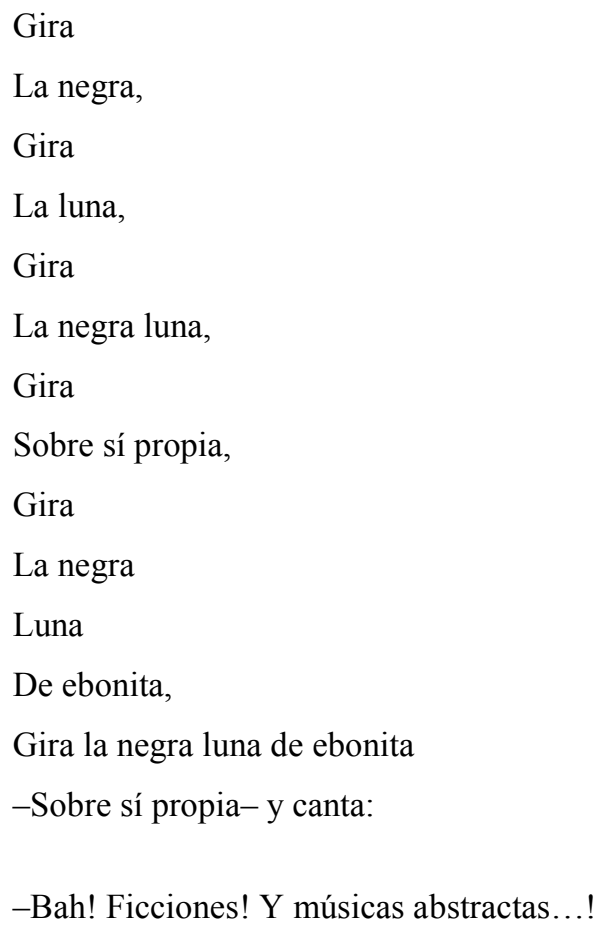

Y, lo que canta, es la Música Misma! (Obras 363, 366)

A la poesía le queda la poesía misma, así ésta sea la expresión desgarrada de una individualidad que al tambalearse en su lugar de enunciación se afirma a sí misma mediante la ironía autodestructiva: "Yo, señor, soy acontista. / Mi profesión es hacer disparos al aire. / Todavía no habré descendido la primera nube. / Mas, la delicia está en curvar el arco / y en suponer la flecha donde la clava el ojo" (428). La impugnación de la poesía se convierte en poesía cuando la nada se transforma en todo, cuando de nuevo "todo existe y no existe". Sobre esta indeterminación se debate la poesía en De Greiff, tanto así que, en palabras de Jiménez Panesso, "el adjetivo 'horro' se vuelve uno de sus favoritos, y de casi todos sus poemas puede decirse que son, según el título de uno de sus libros, 'Variaciones alredor de nada'. 'Nada' es la palabra clave en la obra de León de Greiff' (Antología 35). A través del discurrir de una poesía que se complace en ser poco más que viento, la palabra, como portadora de significados, ha modificado su naturaleza, y sólo encontramos el fluir de un vacío que no obstante integra múltiples y contradictorios sentidos, en una suerte de prolongación delirante o "dionisíaca" - para decirlo con Sanín Cano o Cuartas- de la nada. 
En una dialéctica de modernismo y poética de avanzada, la indeterminación se materializa en una "Nada. Nada de nada. / Nada en dos platos, nada en una dorada vajilla completa" (De Greiff, Obras 285). Sobre el vínculo entre la divagación del discurso y la nada, Cuartas asegura:

El "discurrir" representa la actividad de la escritura que mana de la fuente, reflexiona, recorre e imagina; el discurrir se fija el absurdo como objeto, en la medida en que no parece haber nada obligante que comprometa al escritor; el discurrir desenfada la pereza y la encomia y elogia, inutilizando así la tarea del lector que termina entreteniéndose con "nada", que termina entregándose a "nada" con toda su inteligencia, su placer y su tiempo, igualándose así con el creador que confiesa discurrir y solamente discurrir. (Cuartas 120-121)

Esta "nada" parece actuar como la "Quimérica Ciudad" alrededor (o "alredor") de la cual el poeta vagabundo no para de deambular, de girar como las favilas, como el viento, como la negra luna de ebonita sobre sí misma: "De seguir hé pugnando con el aire / [...] / De seguir hé pugnando con las nébulas" (521-522). En este desvarío alrededor de nada reside otra de las claves de su escritura, el foco de atracción que lo separa de la "turba mesocrática" de otro de sus poemas, no compuesta por la sociedad en general, sino más exactamente por los "rostros estucados de seriedad, revestidos de suficiencia, insufribles de necedad" del contexto literario e intelectual de su época. Por eso, no duda en reconocer, siempre en clave irónica respecto a la noción más institucionalizada de la poesía, su descreimiento frente al prestigio de ésta y de sí mismo:

Para mí no hago nada... acaso humo

Cuando en la pipa blondo aroma quemo,

-Si en el magín devano las ideas

Humo también, color de fantasía...-(Obras 148)

Pero en esa "nada" hallamos también la sustancia explícita de una poesía que se destruye a sí misma para asegurar su permanencia, de una poetización que acepta "la arlequinada, la pirueta cómica, el cinismo, como formas apropiadas para mantener viva la seriedad de la poesía” (Jiménez Panesso, Antología 34). Así como “todo existe y no existe”, la seriedad ya no es seriedad y la poesía ya no es poesía. Ahora, la poesía tiene un nuevo estatuto: 
La poesía parecía ser cosa seria. Poesía

No es sino Nadería. Qué más puede ser Ella?

Yo creo ni en la Nada, que es lo que sólo existe,

$\mathrm{Ni}$ en lo que es la vislumbre de lo que vale Nada.

Mínimo en la altitud, máximo en la miseria,

Yo soy sino la brizna que a viento algún resiste,

Soy sino el mismo viento que a la brizna anonada. (Obras 706-707)

La poesía es viento y brizna: dos polos de una simbología de lo efímero y lo nimio. La seguridad de esto es clara, contundente: "Nada me curo de la Poesía: / la Poesía me resulta vómica" (Nova 33). Cercana a los límites de la antipoesía del llamado "postmodernismo" latinoamericano ${ }^{43}$, pero con una recursividad expresiva mucho más compleja, la poesía es atacada con más poesía: es "estigma, baldón y malatía peorativos. Gafedad, manquedad, tacha y reproche permanentes. Apostolado tonto. Inaptitud e ineptitud consagradas. Inri. Irrisión. Lucro cesante incesante y daño submergente. Oprobio. Agobio una vez más. [...] Tirso y cascabeles de bufón. Cetro de caña de Rey de Burlas. Nasociranesco..." (Obras 563). Sin una verdad que proclamar, un "apostolado tonto" en un mundo en que todo es igual a "nada", la poesía es una redundancia de contradicciones afianzada en la creencia de la "Balada de la fórmula definitiva y paradojal": “¡Todo no vale nada, si el resto vale menos!" (39). En esta paradoja convergen el todo y la nada, en un nudo expresivo que no es unívoco sino igual de múltiple a esas figuras que se suceden y se contradicen. Todo se reduce a esto y al mismo tiempo es mucho más: no por reducirse a la nada esta fórmula paradojal, deja de constituir en sí misma una balada, pues si bien la realidad puede ser todo y a la vez nada, es en la expresión poética -y únicamente allí- donde se debate el dilema del ser en la propia consumición, la existencia de un individuo fragmentado que proyecta en la escritura las tendencias multiformes de un sujeto descentrado.

43 No debe confundirse este "postmodernismo", movimiento "antipoético" de crítica frecuentemente humorística al modernismo hispanoamericano, con la tendencia artística, filosófica y cultural de alcance occidental que presenta tendencias de cuestionamiento a la tradición de la modernidad en general. Esta última tendencia, en su sentido más global, será abordada en un capítulo posterior. 
La tradición dominante en el ambiente literario e intelectual de la Colombia de principios del siglo XX, abocada a la defensa de un orden señorial y del estatismo de la sociedad a partir de la configuración de un tiempo detenido y sin historia, representa la base ideológica que la actitud vanguardista, en cabeza de De Greiff o Vidales, llega a cuestionar por medio de una modificación del material artístico que difumina esa falsa estabilización de la historia. Pero es preciso definir el carácter de ese cuestionamiento. Mientras algunos, como Vidales en ocasiones, se valen del discurso político o periodístico para expresar su rebeldía y su llamado a la revolución estética e ideológica, De Greiff se enfoca en su práctica artística concreta y a partir de allí lanza su propio cuestionamiento. A través de múltiples procedimientos y de la noción misma de la multiplicidad y lo contradictorio, el poeta niega esa pretendida seguridad que la literatura tradicional había querido proyectar y consolidar en la sociedad. La protesta se enfoca directamente en la noción del sujeto y su función en la configuración de sentido. Hay una negación de la base epistemológica en que se sustenta la literatura tradicional, en lo cual juega un papel fundamental el procedimiento de la ironía. La escisión entre sujeto y expresión que ella hace posible es el detonante de una crítica a la posición unívoca de la subjetividad y a su articulación en el discurso que configura y la configura. La contradicción es manifiesta en una expresión marcada por la divagación y la multiplicidad de perspectivas. En este panorama, ninguna estabilidad es posible, ni siquiera la del mismo poeta, que se debate entre estéticas diversas y también contradictorias, fiel a su condición de sujeto disgregado sólo definido por una poética tan única y a la vez tan múltiple, tan propia y tan universal, como bien puntualizó Cobo Borda (63). Es el poeta que clama: “todo está en mí... y en mí no encuentro nada!” (Obras 40). La expresión de un sujeto descentrado cuya divagación llega a los límites de la nada, sólo posible, por otra parte, gracias a la multiplicidad misma. Un sujeto contradictorio que se despliega hacia lo múltiple y lo efímero, perdiendo su identidad y la estabilidad de su lugar de enunciación. Ese sujeto problemático que Albrecht Wellmer, en referencia al psicoanálisis y su efecto de desintegración del Yo, denomina "cadena de conflictos", “encrucijada de fuerzas psíquicas y sociales antes que dueño de esas fuerzas" (Wellmer 75). El rechazo de todo estatismo y autonomía de la subjetividad. El quiebre, en últimas, de esa tradición basada en una ideología del tiempo detenido, mediante la crítica a un sujeto estable y centrado, largamente 
cuestionado desde las vanguardias y, en general, en el arte y el pensamiento más avanzados del siglo $\mathrm{XX}$. 


\section{VARIACIÓN 3: LOS AVATARES DEL YO}

La pérdida de la estabilidad del sujeto de la enunciación en De Greiff, a raíz de factores como la divagación o la contradicción de puntos de vista, pero sobre todo la fragmentación de la identidad en heterónimos con diferentes personalidades, inaugura en la literatura colombiana una nueva concepción sobre el discurso y la manera en que éste configura la subjetividad. Frente a la literatura centenarista de ánimo regional y la literatura modernista de reivindicación de la autonomía individualista, ambas basadas en la idea de una subjetividad consolidada que construye su enunciación con base en posiciones claras y coherentes, el poeta introduce un factor de desintegración de la univocidad por medio de la desestabilización de su propia subjetividad y la multiplicidad de voces y personalidades que ello genera. La enunciación desestabilizada rompe con la idea del sujeto único y unívoco en que se sustentó gran parte de la literatura hasta finales del siglo XIX, estableciéndose así uno de los principales vínculos con concepciones características del siglo XX. La poesía en De Greiff, respecto a la naturaleza múltiple del sujeto y su configuración en un discurso polivalente, está muy lejos de las poéticas centenaristas o modernistas que aún conciben la estabilidad del pensamiento como base de la expresión, sin profundizar en los conflictos de la subjetividad, entendida en la modernidad según una concepción racionalista del lenguaje. La poesía en De Greiff desestabiliza esa idea moderna del sujeto y la somete a los vaivenes azarosos de un pensamiento que se define como múltiple, caprichoso y contradictorio. Esta sola característica da idea de la magnitud de la ruptura propuesta y de las connotaciones que de ese modo adquiere la crítica a la institución literaria tradicional, denominada generalmente con el nombre -no menos múltiple, caprichoso y contradictorio- de "vanguardia". En efecto, las escuelas que presiden la institución literaria de principios de siglo en Colombia -los centenaristas y el modernismo de Valencia- prolongan no sólo tendencias decimonónicas regionalistas o sacralizantes de la poesía, sino principalmente la estabilidad discursiva ajena a los conflictos de la subjetividad en entornos contemporáneos 
de discontinuidad. Esa característica de la poesía en De Greiff, ya del todo asociada a estéticas del nuevo siglo, es fundamental para determinar su vanguardia, incluso más que la articulación de estructuras poéticas y musicales, la cual, al ser otra de las muchas síntesis de lo múltiple, se enmarca en aquella. La diferencia que introduce esta poesía en el sistema literario tradicional, como lo diría Bürger, es la fragmentación múltiple de una subjetividad que ya no puede ser entendida según los parámetros unívocos del racionalismo o la filosofía utilitarista, claves en el desarrollo de la mentalidad finisecular, ni mucho menos según la línea vertical del orden patriarcal que todavía domina las estructuras más básicas de la sociedad. Centenarismo y modernismo, en apariencia contrarios pero al final convergentes en la defensa de un estatismo que no ataca los privilegios y las concepciones del pasado, mucho menos en lo que a nociones epistemológicas se refiere, se ven objetados en la base misma de su función expresiva, es decir, en la posición del sujeto autónomo que no admite alteraciones en su coherencia interna. La vanguardia en De Greiff, entonces, se construye en oposición a la univocidad del pensamiento y por lo tanto del sujeto que se expresa en el discurso, y en esta lucha emergen sucesivamente distintas personalidades que representan, como ningún otro elemento, la mejor encarnación de la fragmentación a que se ve sometida su posición discursiva.

La fragmentación de la subjetividad en De Greiff no es un procedimiento que se manifieste de forma aislada a la problematización de la escritura. Más que "otro" de los componentes de su poesía, es fundamental en un proceso de designificación de la palabra que socava la base misma del sujeto de la enunciación. De una subjetividad estable y centrada, esto es, cerrada, llegamos a una subjetividad abierta que da vía libre al curso de la existencia, así ésta arrastre consigo la seguridad de la identidad fundamentada en el discurso. Como lo señala Cuartas, al establecer la diferencia entre las concepciones de "libro" y "escritura" en el poeta, mientras el primero se relaciona con una enunciación ya configurada, ironizada constantemente con los calificativos de "libracos" o "mamotretos", la escritura representa la desarticulación de un orden de representación y la apertura a modalidades de expresión, y por tanto de existencia del sujeto en la realidad, menos estables e inconmovibles:

Habría que distinguir precisamente entre el "libro" (totalidad cerrada y, por lo tanto, "muerta" y que lleva a la muerte) y la "escritura" entendida por ejemplo en el sentido derridiano como: espacio 
abierto, fluyente, diseminante. La poesía greiffiana que se pierde en galimatías, busca en lo inexpresable y en lo musical, la gratuidad de una libertad creadora que aspira a sobrepasar la naturaleza y la vida. (Cuartas, “León de Greiff” 117)

Pero "sobrepasar la naturaleza y la vida" es, ante todo, reconfigurar la posición del sujeto que se define en relación con ellas; en otras palabras, sobrepasarse la subjetividad a sí misma. Desde el momento en que la escritura se presenta como potencialidad abierta, la subjetividad asociada a ella no puede pretender mantener una posición estable. La apertura del sujeto es la transgresión de lo ya representado, incluido él mismo, y su resignificación. Los heterónimos en De Greiff, como resignificación del sujeto de la enunciación, forman parte fundamental de una concepción de la escritura menos abocada a la "fijación" que a la “dispersión”, y por eso están indisolublemente ligados a sus demás procedimientos de desrealización subjetiva, como la ironía que desplaza y reubica al Yo, el discurrir sin sentido en medio de un aluvión de palabras donde la identidad naufraga, o la expresión de la "nada" que resulta ser ese "sobrepasar" de la existencia antes presuntamente estabilizada por el sujeto. Jaime Mejía Duque, citado también por Cuartas en alusión al "aluvión” de palabras, retoma la problemática de los términos castizos o arcaicos en el poeta, sobre todo en relación con lo que llama su "barroquismo", y afirma:

En la literatura lo barroco empieza con el afán por totalizar tanto la realidad física como las sensaciones en el proceso de la expresión. Pretender nombrarlo todo, decirlo todo, sugerirlo todo, es proponerse lo barroco por tarea. Al nivel de la literatura volvemos pues a encontrarnos con el horror al vacío que había inspirado la ornamentación barroca en América y Europa y que, según Hegel, manifestaba el caos de las formas en el mundo asiático... En su oficio de poeta, De Greiff aboca el idioma y el mundo en torno como si se tratara de descubrirlos y de valerse de ellos por vez primera y última, recomenzando y agotando así en raudo ciclo el milenario trabajo de la voz humana: genuina vocación de nombrador. Entonces arrastra consigo aluviónicamente las palabras que se habían fosilizado en todos los diccionarios. Tal un cíclope en acoso hacia el aire; remueve capas y capas de significaciones (Mejía Duque, 113).

No obstante esta certeza sobre la resignificación del mundo a través del ejercicio incesante de "nombrador", asociado por Cuartas con un "delirio", una exaltación del acto de nombrar que pretende "abarcar el universo con la palabra" (Cuartas, "León de Greiff" 120), es preciso insistir en que la modificación se opera principalmente en el estatuto de este 
"nombrador": en la remoción incesante de capas de significaciones, la primera significación removida -y la única, si se quiere- es el sujeto de la enunciación. El conflicto, antes que con la "realidad", es con el orden que ésta adquiere en la configuración de la subjetividad, y ésta se define, por otra parte, en oposición a esa "realidad" que ella había estabilizado. El aluvión de palabras desata entonces las relaciones de significación previstas por el orden del discurso tradicional, y arrastra consigo no solamente las representaciones articuladas en las palabras, sino la estabilidad del acto enunciativo de ese "nombrador" que configura las palabras, en cuya figura léxica, al modo de una especie de inversión de la jerarquía de los elementos discursivos, ya no prima el sujeto, multiforme y contradictorio, sino la acción, incesante y avasalladora. La escritura es predicado absoluto -aspas de molino sin grano que moler, viento rugidor de palabras sin sentido- que desplaza en su torbellino al sujeto, lo pulveriza y reconfigura sus trozos. El "nombrador", en estricto sentido, no es el Yo, pues esta construcción es rebatida, sino los restos del Yo tras su confrontación con ese aluvión de la escritura, encarnados ahora por múltiples Yo que se encuentran y desencuentran en el fluido amorfo del sujeto disperso. Esta es la "diseminación" del poeta en la escritura, planteada por Cuartas, en virtud de la cual el ejercicio de la ironía en De Greiff, "más que un arte de las superficies y las dobleces lingüísticas del humor, [es] un valor coextensivo del Yo ante la representación" (118-119); es decir, la realización epistemológica de este Yo diseminado:

\begin{abstract}
Articulando con la concepción de un arte de "nombrar", León de Greiff se sirve de la ironía para aludir al poeta, al pregonero de palabrerías; un fenómeno de coextensividad del Yo en la escritura que hace depender la obra de León de Greiff de la que Gilles Deleuze denominó “ironía romántica”, descrita como: "La posición de la persona como clase ilimitada, y empero con un solo miembro (Yo)". La ironía tiende entonces un puente impreciso que aproxima y aleja, reúne y dispersa; la escritura de De Greiff representa en este sentido una síntesis a través de la cual el Yo se representa sin lograrse, recogiéndose y alejándose de sí por una intervención en la dinámica de la escritura. León de Greiff representa al poeta con insistencia y dramatismo, abarcando a un tiempo su verdad y transparencia, como su falsedad y divergencia (112-113).
\end{abstract}

Este conflicto del sujeto de la enunciación al nivel de la escritura en que se configura, se sintetiza, según el autor, en la tesis de Soren Kierkegaard sobre el estatuto de la realidad en el ironista: "si bien la realidad dada pierde así su valor para el ironista, ello no es en tanto 
que realidad de pasada que debe dejar el sitio a otra más auténtica, sino porque el ironista encarna el Yo fundamental para el que no existe realidad adecuada"44; en otras palabras, la ironía no es un simple recurso retórico en la que una realidad subyace a otra realidad menos "verdadera", sino principalmente la representación del "Yo inadecuado" a toda realidad:

El mecanismo efectivo de la ironía consiste en de Greiff en la posibilidad de señalar lo que hay de falso o de unilateral en la tesis en la que finge participar; el fondo reside en el Yo y en su acto de “decir”; León de Greiff es poeta, y como tal, "violenta perorata” es su poesía. La ironía es destructora, choca violentamente la sustancia del Yo creada en la escritura, porque en el fondo su vinculación más íntima es la tragedia; la ironía a este respecto no es simple artificio, por el contrario, es confrontación del individuo creador con el lenguaje o con las cosas sensibles por él designadas. Querer alabar el oficio de poeta dando rienda suelta a la escritura repercute de manera ambivalente y trágica en la burla del poeta, un poeta que procede, en el caso que analizamos, de León de Greiff como sujeto, pero que se disemina en otros tantos poetas. (113-114)

La ironía, instrumento clave en la crítica de concepciones elevadas de la poesía, en torno a la cual gravitan representaciones de vacuidad y sinsentido de un oficio no obstante ejercido con intensidad, se convierte así en el detonante de un sujeto inadecuado que en De Greiff retorna en múltiples y contradictorias subjetividades, emanaciones sucesivas y a veces simultáneas de distintos momentos del Yo. Los heterónimos, igual que la ironía, no son un procedimiento más entre los abundantes recursos retóricos del poeta, sino el producto de la confrontación con una realidad en la cual el sujeto ha perdido toda seguridad, y por tanto, el debatirse consigo mismo como organizador fallido de esa realidad, al modo del "acontista" cuya "profesión es hacer disparos al aire", o de Beremundo el Lelo, "singlando a la deriva, no en orden cronológico, ni lógico -en sin orden-" la desarticulación irónica de la poesía como configuración del sujeto en esa realidad, es entonces la clausura de la subjetividad unívoca y cerrada. Sin control sobre el lugar del sujeto en la enunciación, y perdida así la convicción de la poesía simbolista como acceso de ese sujeto a la realidad de la existencia, la identidad se quiebra bajo la despersonalización de la ironía, y la única manera de reconfigurar sus trozos, en instancias en que la coherencia de la enunciación ya ha sido destruida, es mediante su fluir desordenado y conflictivo. La

\footnotetext{
${ }^{44}$ S. Kierkegaard, citado en Cuartas, "León de Greiff" 113.

${ }^{45}$ De Greiff, Obras 623. Los nombres de los "heterónimos", en adelante, se mencionarán sin especificar que lo son, teniendo cuidado de que el contexto de la escritura, por sí mismo, lo dé a entender.
} 
ironía desemboca entonces en la fragmentación de la subjetividad cuando la individuación poética sucumbe a su contundencia. Esta fragmentación ya no sólo es irrevocable, sino que crece a medida que la escritura que "disemina" al Yo profundiza en la irrevocabilidad de esos fragmentos de individuación. Y la irrevocabilidad es sancionada por el "nombrador", entidad única y múltiple, que fiel a su condición de acción incesante, de predicado absoluto sin sujeto único y estable, prolifera en denominaciones de sí mismo y de esos otros que convergen en él, en quienes, a su vez, él también converge. La imbricación de identidades es manifiesta y la subjetividad experimenta una designificación por la cual ya nunca será una misma, pero tampoco sabrá si llega a ser del todo "otra". La subjetividad es múltiple en su fragmentación, pero solitaria en su conjunto, y por eso los fragmentos conviven unos con otros, en constante diálogo con ellos mismos, aunque jamás seguros de hasta dónde llegan “ellos mismos" y cuándo interactúan con "otros". Un sujeto pregunta en dónde están sus "vagos anhelos innocuos", y una entidad paralela le responde: "Anclado. Al pairo. En mi sitio’. Dijo El Otro" (310). Es la trampa de la desintegración de la identidad: una vez detonada ya no se sabe cuándo se detiene. Los heterónimos proliferan a lo largo de los mamotretos del poeta, su número es cada vez mayor y parecen abarcar todo cuanto existe en su realidad. A veces, el resto de la existencia sólo parece girar alrededor de ellos, e incluso parece que "ellos" han llegado a ser ya ese "resto de la existencia". Así como hablar “a la olvidosa gente, es a saber: / al aire, al viento, al sol, al río, al mar...” (147), así mismo, igual que con esa "olvidosa gente", el poeta elabora la identidad múltiple de sus subjetividades. El poeta es él mismo y otros a la vez. La multiplicidad converge en una individualidad que no cesa de fragmentarse para girar alrededor de sí misma, o diseminarse, si se quiere, con la fuerza de la palabra desbordada, como en la "Balada intrascendente de Aldecoa, Leo y Gaspar”, quienes “van diciendo versos / al mar, / van diciendo versos / al monte, / versos al mentido / horizonte", lejos de ciudades no obstante "caras a ese triple corazón", "recorriendo el camino / diciendo versos sin tino" (Obras 42-43). El poeta múltiple se disemina en versos sin tema aparente, sin destino, sólo encadenados por el acto de dispersión que entraña la metáfora del vagabundo, convertido así en el tema por excelencia. Ese "triple corazón" es a su vez desarrollado en cada una de sus entidades dispersas, en numerosos poemas donde se expresan con un carácter y un lenguaje diferenciados. "Leo Legris", signo del hastío y del ademán de lo esquivo, surgido de 
conflictos entre el poeta y el medio intelectual, es una voz recurrente, marcada además por las contradicciones inherentes a una subjetividad inestable:

Leo Legris es el nombre que porta

-Para esquivar el irónico gesto-

Mi extravagancia, que, rïendo, soporta

La burla, la estultez, y el elogio indigesto.

Mi aburrimiento es largo, pero la vida es corta.

Mi vanidad... ¡Mi vanidad no vale el resto...!

Y el resto es casi siempre lo que a ninguno importa... (96)

El "resto" de la existencia, lo que está "más allá" de ese trozo de identidad llamado Leo Legris, es ambiguo, contradictorio, igual que él y por la misma razón que él. El heterónimo, más que fijar una identidad, reproduce el impulso de despersonalización, tanto del sujeto lírico como de la totalidad de la que forma parte, incluido aquí el heterónimo mismo. No se sabe dónde empieza éste o dónde termina, cuáles son sus límites frente al resto de la totalidad dispersa. Todo fluye y se transforma, integrándose y desintegrándose en nombres provisionales. Un heterónimo no es una marca autónoma de sí misma, como tampoco el poeta desintegrado ni el resto de la existencia en la que éste actúa y se expresa como un fluir constante. El impulso de escisión no se detiene, sino que fracciona también los restos de la individualidad ya desintegrada de antemano. El alma de Leo Legris se disemina en esa existencia que es él mismo y a la vez ese resto que "es casi siempre lo que a ninguno importa", al ritmo de la desintegración progresiva de la escritura en versos, palabras, sílabas:

\footnotetext{
Alma que está en la rugosa

Corteza del chopo gris,

$\mathrm{Y}$ en la gris

Y misteriosa,

$\mathrm{Y}$ en la gris

$\mathrm{Y}$ en la dudosa

Serenidad de la tranquila

Pupila

Faceciosa
} 
De

Le-

Gris... (17)

El alma no es una facultad absoluta o trascendental, sino la manifestación provisional de un trozo de subjetividad fragmentada. No existe un "alma", sino las "almas", las "multánimes almas que hay en mí” (21). Convergencia de subjetividades dispares, De Greiff es también, como ya se ha dicho, la integración de múltiples perspectivas estéticas, en cuyo conjunto no predomina una en particular sino la condición misma de la multiplicidad y la contradicción. El sujeto no se desborda en un sentido unívoco. Cuando la subjetividad se desestabiliza, la coherencia racionalista pierde su significado y la unidad enunciativa es alterada. El poder de la expresión no reside en el marco referencial de una estética en particular, sino en una yuxtaposición que señala la provisionalidad de las estéticas anteriores:

\footnotetext{
Alma romántica-Flor de Lys-,

Alma para una epopeya,

Para un idilio hueco...

Alma clasicoide, alma

De un verso bien medido, bien

Aconsonantado, vacuo y fofo...

Alma decadente, alma de Narciso,

Alma para urdir un poema

Simbólico, vagaroso y frágil... (20-21)
}

En una subjetividad en conflicto, las "almas", como los recursos estéticos o las referencias culturales ironizadas, concurren en desorden a fluir en el espacio de la escritura, que para Cuartas, según se ha visto, es el espacio de diseminación del Yo. La coherencia está dada entonces por estas yuxtaposiciones que generan la clausura de exclusividades en favor de la tensión producida por la contradicción. En este horizonte, es impensable desde todo punto de vista un sujeto de la enunciación sin yuxtaposición de términos contradictorios. La única coherencia posible del sujeto consigo mismo, es decir, con los innumerables trozos que lo conforman, es esta contradicción, esta yuxtaposición de fragmentos heterogéneos, cuyo 
juego verbal consolida la estética misma del poeta. En esta tensión perpetua, ningún elemento puede considerarse unívoco y cerrado, ni la logicidad del pensamiento ni sus construcciones. Los componentes de la individualidad se despersonalizan: "Alegría... por qué me entristeces? / Y no la de los otros: / La mía! / La que poseo numerosa...” (4). La multitud habla en nombre del sujeto despersonalizado: "Lloran mis tristezas por las alegrías / que ya se murieron" (74). La subjetividad no puede entonces comprenderse, en exclusiva, en virtud de una posición enunciativa estable o concreta. El alma "clasicoide" contradice el alma "romántica" o la "decadente", así como cualquiera de éstas contradice las otras dos. Pero aquí la contradicción no es un factor excluyente. Por el contrario, es la materia de la existencia poética, consubstancial a ella, su razón de ser y su prolongación. No se trata de establecer la unicidad absoluta, como en la poesía tradicional fundada en la idea de la subjetividad estable, sino de negarla mediante la tensión de unicidades provisionales. La ironía juega, como en todo, un papel fundamental. En perfectos tercetos encadenados, una especie de romanza en verso "bien medido" 46 , el poeta censura, por un lado, a poetas "de cuadrícula y balanza", y por otro, a quienes "gimen patética romanza". Pero esos "otros" poetas se nombran en función de su propia individualidad, entran a formar parte de ésta

\footnotetext{
${ }^{46}$ De Greiff integra, en toda su obra, versos "bien medidos", otros no tan simétricos, libres, monosilábicos, etc. Además, escritura en prosa con lenguajes narrativos, descriptivos, científicos, administrativos, etc., que se corresponden con la alteridad contemporánea de recursos compositivos. En esto, la alteridad es comparable a la yuxtaposición de referentes estéticos contradictorios, nivelados por el fluir discontinuo del sujeto en la escritura. Por ello, su estilo, si se trata de establecer conclusiones generales, debe analizarse en función de su variedad, pues la limitación a un estilo en particular, sin conciencia de los demás, hace que toda conclusión pueda ser cierta respecto a una sección individual y falsa respecto a otra, lo cual extrema su parcialidad y niega el carácter más fundamental de esta poesía, la multiplicidad y la tensión resultante de elementos contradictorios. Estos juicios arbitrarios abundan en la crítica del poeta durante décadas, y no serían tan nocivos para una visión de conjunto si no pretendieran, en la mayoría de los casos, referirse a "la obra" del poeta, así, en su totalidad, y no, con previa advertencia explícita, a "unos poemas" en particular. De este modo, se han encontrado elementos que le han merecido el nombre de bardo medievalista, poeta clasicista, poeta romántico, poeta parnasiano, simbolista o modernista, y otros más que -si bien no son del todo falsos, pues sus recursos diversos, tomados aisladamente, pueden apoyar éstos y otros muchos calificativos- pecan de arbitrariedad al formularse cada uno como la definición general del poeta, sin tener en cuenta las contradicciones que éste puso en juego. La "Valoración múltiple sobre León de Greiff", compilación de apreciaciones y textos críticos hecha por el historiador Arturo Alape, da cuenta de esta diversidad de conclusiones arbitrarias, las cuales, por su misma parcialidad, caen inadvertidamente en el juego de contradicciones desarrollado por el poeta. En la crítica más contemporánea, como ya quedó dicho, se ha intentado asimilar de otro modo la complejidad de esta escritura en conjunto, y así han surgido reflexiones que, al profundizar en las implicaciones sociológicas respecto a la institución literaria y en problemáticas del sujeto a partir del procedimiento de la ironía, la encuadran en estéticas más propias del siglo al que realmente pertenece, como es el caso de los planteamientos de Estripeaut Bourjac y Cuartas. En verdad, una percepción general de esta obra sólo es posible, como se ha insistido, si presupone la yuxtaposición de múltiples perspectivas estéticas, y por lo tanto la clausura de la exclusividad de una u otra poética anterior: en suma, una estética de vanguardia.
} 
como trozos aislados, puesto que son los restos de vida que la "Señora muerte", signo del tiempo irrevocable, va dejando atrás:

Señora Muerte que se va llevando

Todo lo bueno que en nosotros topa!...

Solos -en un rincón- vamos quedando

Los demás... igente mísera de tropa!

Los egoístas fatuos y perversos

De alma de trapo y corazón de estopa...;

Manufactores de fugaces versos;

Poetas de cuadrícula y balanza,

A toda pena, a todo amor adversos...;

Los que gimen patética romanza;

Lacrimosos que exhiben su película;

Versistas de salón y contradanza-

Vates ultra-sensibles y banales

Que ningún vaho de verdad anima...

Gramáticos solemnes y letales...

Malabaristas de estudiada esgrima!

... ¡Oh tristeza perenne de las cosas

Que no tienen sabor, -hechas a lima! (98)

En un poeta que practicó diferentes niveles de ironía y despersonalización, la alusión a los “otros" poetas no deja de ser, igualmente, una alusión a sí mismo; pero además, esta cruda autocrítica toma distancia de un medio literario de figuras sistemáticamente consagradas, acostumbradas al mutuo elogio y la grandilocuencia. El juego expresivo es doble y ningún sentido predomina sobre el otro. Como señala Kierkegaard en su noción de la ironía, ésta no presenta una "realidad de pasada" que esconde otra "más auténtica", sino que representa el "Yo fundamental" para el que no hay "realidad adecuada". Una poética de la yuxtaposición que se contradice constantemente no puede ser comprendida desde una 
perspectiva única y excluyente de las demás, pues ello implicaría eliminar las tensiones subjetivas que son fundamentales a esta expresión. El autor es una entidad individual, ciertamente, pero esa individualidad no es un todo indisoluble que se configura en la escritura de modo continuo. Por el contrario, es una entidad fragmentada y discontinua que supone una concepción de autor diametralmente opuesta a la que predomina en la tradición del país de la época ${ }^{47}$, caracterizada por ánimos de renovación -entiéndase restauraciónpatriótica, y un modernismo ya neutralizado, con ideas como el afianzamiento de un sujeto nacional o el arte como sustento ideológico de órdenes señoriales decimonónicos. En ambos casos, el impulso de restauración conservadora es desafiado por un sujeto conflictivo que se afirma y se niega al mismo tiempo, que no define una posición estable de enunciación, que hace de la escritura el espacio de dispersión de su multiplicidad contradictoria:

Dicen que soy sonámbulo, que soy loco, que soy

La mar de cosas malas -para el criterio ambiente-;

Que soy frío y abstracto, recóndito, incoherente...:

Ni soy lo que ellos dicen... ni en lo que soy estoy!

$\mathrm{Y}$ vosotros, los hombres del corriente criterio:

No inquiráis el misterio, no inquiráis el misterio...!

Yo soy Don Luis Segundo de Nihilia, y mis guardas

Vienen tras mí, y mis reitres, y mis pajes, dispuestos

A elidir vuestras testas bilingües y bastardas...! (18)

\footnotetext{
${ }^{47}$ Y del continente, pues el carácter combativo de las vanguardias de entonces, como indica Sarlo al hablar del contexto argentino, sólo es concebible en un campo intelectual lo bastante desarrollado y consagrado en su institucionalidad, como para generar, en consecuencia, la necesidad de la ruptura: "La radicalidad de la vanguardia [...] siempre es una función relativa al campo intelectual que [...] encuentra constituido y consagrado. La ruptura aparece vinculada con la extensión y desarrollo del campo intelectual, cuya legalidad la vanguardia niega. La consolidación y el prestigio de la tradición cultural crean, paradójicamente, la fuerza de su vanguardia" (Sarlo 212. V. pág. 85 del presente trabajo).
} 
El cortejo de Don Luis Segundo de Nihilia, heterónimo combativo en pugna con el "criterio ambiente" del medio intelectual de su época, evoca los fragmentos de subjetividad de un poeta que, como De Greiff, siempre estuvo solo en su estética. Más que miembros de una "escuela" que el poeta nunca tuvo ni promovió, son miembros sueltos de una identidad dispersa en un espacio de despersonalización. Lo múltiple está dentro de la individualidad del poeta. Él sabe que dentro de sí mismo debe buscar los elementos sueltos que lo conforman. Si bien estos elementos parecen trascender a veces su individualidad, no hay que engañarse, pues el universo entero es la prolongación de esos elementos que abarcan la totalidad configurada, de mil y contradictorias maneras, en la poesía: "Por mes de abril, / iba por sendas, riberas, lomas... / buscando, buscando... / lo que nunca encuentro / por fuera de mí" (11). La fragmentación se efectúa entonces en diferentes niveles. No es claro hasta dónde llega esa identidad denominada "De Greiff" ni la identidad de sus múltiples heterónimos. Todo parece pulverizarse y reconfigurarse sólo para pulverizarse otra vez y adquirir nuevas configuraciones. Los restos de la subjetividad detonada se remueven y combinan de maneras imprevistas. El "Trío Coautor" de la "Farsa de los pingüinos peripatéticos", Gaspar von der Nacht, Matías Aldecoa y Leo Le Gris, se conforma gracias a enrevesadas peripecias de éstos entre "ellos mismos" y con "otros" que comparten, todos, su estatus fragmentario y volátil:

La edita MATÍAS ALDECOA, unidad del TRÍO COAUTOR (clarinete, fagot y trompa), con el asentimiento de los "altos heliotropos" y con el de LEO LE GRIS, unidad del TRÍO COAUTOR, en su nombre y en el de GASPAR VON DER NACHT, unidad del TRÍO COAUTOR, desaparecido misteriosa u oscuramente en KORPILOMBOLO (LAPPLAND; SVERIGE; 66 ${ }^{\circ}$, 40’ aprox. latitud Norte; $23^{\circ}, 10^{\prime}$ aprox. longitud Este, de Greenwich), que allá fuera, GASPAR, a caza de sus dos compañeros, metido en error por una cierta consonancia existente entre KORPILOMBOLO y el país en donde MATÍAS Y LEO, inducidos en mesteres odiséicos por un supuesto viking de categoría ínfima, ERIC FJORDSON, pescador de bacalaos y arenques y de poesías iodadas y salinas, buscaron "la vida en bruto", hace ya de ello. (102)

Este caótico preámbulo en prosa se aproxima, como ninguno, al problema de la identidad fragmentada en relación con la realidad de la que forma parte el poeta, y que se proyecta en su subjetividad y desde su subjetividad -pues más que "representación" hay "recreación"de muchas formas. No sólo figuran los tres heterónimos que conforman el "Trío Coautor", 
sino que, bajo esta denominación, se establece momentáneamente una entidad creadora desdoblada en tres, fundada en tres trozos de la subjetividad lírica, y por lo tanto, de la posibilidad de despersonalización consciente de esta subjetividad. Ello implica que a este Trío Coautor no lo podamos identificar plenamente con De Greiff, sino sólo con tres trozos de su identidad, la cual ha sido sometida, en la escritura, a una escisión. Incluso, se observa otro heterónimo que cumple una función "motivante" del viaje que disuelve al Trío Coautor, derivado de la cultura nórdica de los antepasados del poeta. Entonces, la composición, en palabras de la misma presentación, está "urdida" por Aldecoa, especie de juglar de las montañas de la región de Antioquia donde está enclavado el pueblo al que viaja con Le Gris, este mismo Le Gris, identidad del hastío y el deseo de fuga, y Von der Nacht, formación derivada de Gaspar de la Nuit, el personaje simbolista de Aloysius Bertrand que aquí revive para entrar al universo caótico y multiforme del poeta. La orquestación musical, también presente en este juego de identidades a través de la identificación del Trío Coautor con Clarinete, Fagot y Trompa, nos introduce a una de las técnicas más recurrentes en De Greiff, la imbricación de lenguajes poéticos y musicales, donde terminología, nomenclatura, estructuras formales, etc., se unen para desdibujar los límites entre melodía y verso, que como los heterónimos, se remueven y vuelven a configurarse de múltiples formas. Toda identidad está desdibujada, hasta la del pueblo donde Aldecoa y Le Gris buscan la "vida en bruto" (alusión a Bolombolo, pueblo donde el poeta escribió parte de su obra), confundida aquí, por razones de consonancia, con Korpilombolo, pueblo sueco que evoca, de nuevo, a los antepasados del poeta. Nada es gratuito. Las indefiniciones son intencionales. Las identidades se destruyen en un modo de hacer poesía, de desbordarse el sujeto lírico violentamente en la escritura, que apuesta por la destrucción de su identidad estable y las seguridades epistemológicas de su discurso. Es un arte que dice mucho, pero a la vez, y por ello mismo, busca decir "nada", buscar ser "nada", tanto al nivel de la expresión de "verdades" como al nivel de las identidades, múltiples pero provisionales, del poeta:

\footnotetext{
Violenta perorata

$O$ verbal hecatombe

Inverosímil;

Violenta perorata
} 


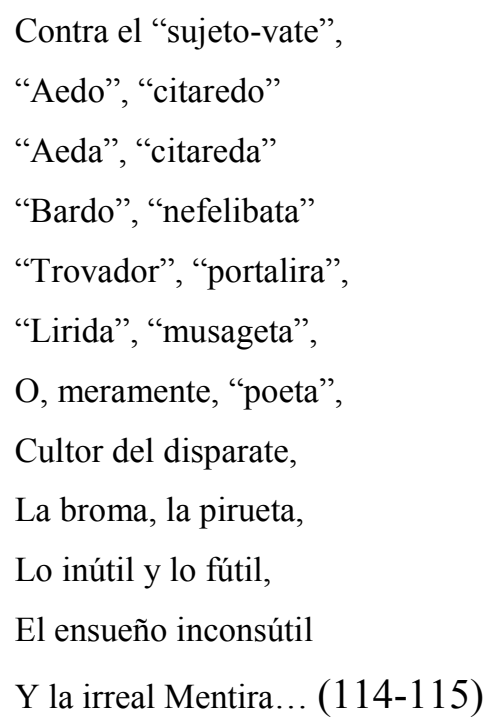

Pero si es consigna la destrucción de las identidades y de su configuración en la escritura, entonces, ¿a quién y en qué palabras creer? Retomando los argumentos sinuosos del poeta, diríamos que la respuesta es compleja, pero a la vez sencilla. No hay que creer en nada, sino sólo en la facultad de dejar de creer en todo, incluido, sobre todo, el "criterio ambiente" del medio intelectual dominante. La posibilidad que brinda De Greiff es la de romper con un discurso demasiado fundado en la convicción sobre la estabilidad unívoca del sujeto. La contradicción es clave en la construcción y el desarrollo de la subjetividad, y por lo tanto, al nivel de su expresión, otra escritura es posible. No estamos frente al sujeto del racionalismo que confía en el poder y la seguridad de su pensamiento, ni frente al sujeto ilustrado que pretende establecer un dominio de la naturaleza a través del concepto que él mismo desarrolla. Estamos frente al sujeto desintegrado, el Yo múltiple, que ha tomado conciencia de que no es un fluir continuo, sino un entrechocar constante de fuerzas discontinuas: "Ese que danza con su propio Ente / y con su Doble y con su Sombra" (511). La discontinuidad es la regla. Al negar la univocidad se niega la existencia de verdades únicas. Sólo existe la tensión y la contradicción. En suma, lo múltiple y lo provisional. El Trío Coautor se congrega momentáneamente para disgregarse después hacia espacios y tiempos diferentes. Gaspar, "paradigma del individuo", se "divorcia" (268) de Leo y Matías en busca de un norte de evocaciones ancestrales para el poeta, y "desaparece" al no poder llevarlos consigo, en un viaje que separa los componentes de este sujeto colectivo a la vez 
que entrecruza referentes espaciales opuestos, dando a entender que los contrarios son concomitantes, del mismo modo que la disgregación es el destino del individuo:

Yo imagino un País, un borroso, brumoso País...

¿Cómo el país?

¿Dónde el país?

Oh amigos: vámos, vámos al Norte, vámos al Norte...!, aunque sea dando la vuelta por el Sur. (269)

La síntesis de lo fragmentario y contradictorio, como desarticulación del individuo unívoco u orgánico cuyos elementos concurren armónicamente en un mismo y definido esquema de coherencia, es la puerta hacia el siglo XX que De Greiff abre en la literatura colombiana, y de tal forma hace suyos recursos característicos del arte contemporáneo. La superposición de identidades en esquemas contradictorios puede analizarse desde lo que Bürger entiende por "montaje", derivación del concepto de alegoría barroca en Benjamin y característica fundamental del arte de las vanguardias. En una inversión del círculo hermenéutico, la alegoría suspende la articulación tradicional entre la parte y el todo, aislando las partes de su contexto inicial e integrándolas en nuevos espacios de significación. Se trata de un procedimiento de "devaluación barroca del mundo" que en las vanguardias asume una nueva función, la de afirmar de otra manera ese mundo al devaluar su representación artística tradicional por medio de la multiplicación de materiales y puntos de vista heterogéneos. Es la base de la inorganicidad de la obra en el arte de vanguardia:

Para el vanguardista [...] el material sólo es material; su actividad no consiste principalmente en otra cosa más que en "acabar" con la vida de los materiales, arrancándolos del contexto donde realizan su función y reciben su significado. El clasicista ve en el material al portador de un significado y lo aprecia por ello, pero el vanguardista sólo distingue un signo vacío, pues él es el único con derecho a atribuir un significado. De este modo, el clasicista maneja su material como una totalidad, mientras que el vanguardista separa el suyo de la totalidad de la vida, lo aísla, lo fragmenta. (Bürger 133)

El vanguardista es entonces un desarticulador de materiales o significados, cuyas formas ya vacías -en nuestro caso las palabras - articula a su vez en nuevas redes de significación. Este es el sentido del "montaje": "El vanguardista [...] reúne fragmentos con la intención de fijar un sentido (con lo cual el sentido podría ser muy bien la advertencia de que ya no 
hay ningún sentido). La obra ya no es producida como un todo orgánico, sino montada sobre fragmentos" (133). Por ahora, De Greiff no comporta una devaluación absoluta de la realidad a través de la "inorganicidad", tal como aquí se expone, pues no lleva a cabo la fragmentación radical de las partes constitutivas del lenguaje tradicional en el sentido en que Bürger lo entiende; pero su destrucción del lugar estable y unívoco de enunciación afronta el problema en su sentido más decisivo, pues se encamina al centro de la discusión sobre esa "realidad": el sujeto que la configura al configurarse a sí mismo en el lenguaje. El significado no se articula según la intención de un sujeto indisoluble que "representa" la realidad, sino en el problema de una representación que está mediada por una subjetividad descentrada y contradictoria ${ }^{48}$. El sujeto de esta escritura no es una entidad autónoma ni plenamente diferenciada, sino una "cadena de conflictos”, "encrucijada de fuerzas psíquicas y sociales antes que dueño de esas fuerzas" (Wellmer 75). La realidad no es entonces un fluir continuo de significaciones estables, sino el contexto de la existencia desestabilizada que se representa a través de trozos de subjetividad. En una subjetividad fragmentada no es posible la existencia de una realidad continua, y por ello el lenguaje, como expresión que configura la realidad a medida que configura el sujeto, es una serie discontinua de significaciones. Las identidades sueltas deben reconfigurarse, "montarse" otra vez, en atención a una fractura irrevocable. El montaje de subjetividades resulta ser entonces el producto de un tratamiento especial de significados, por el cual éstos se desligan de su contexto original para asumir nuevas funciones en redes de significación diferentes. El Yo no es más el Yo, sino un fragmento suelto y constantemente variable que discurre al lado de lo heterónomo, lo cual en algún momento, gracias a su diferenciación de lo que está más allá o más acá del sujeto, le daba la seguridad de su existencia. Lo autónomo y lo heterónomo pierden sus límites. No se sabe dónde termina uno y dónde comienza el otro. Hay una desarticulación de los componentes de la subjetividad, cuya materia fragmentaria

\footnotetext{
${ }^{48}$ Tomás Vargas Osorio se refiere al tema de la representación de la palabra en De Greiff como un círculo del todo irregular aunque "estratégico" -no hermenéutico, pues no hay armonía alguna-, en términos que lo relacionan con la disolución de la individualidad y la irrupción de lo múltiple, al modo de la "escritura diseminante" formulada por Cuartas: "El poema leondegreiffiano no tiene anatomía. El verso en él carece de gravedad, es ingrávido, buido, etéreo, una línea difuminada a veces y retorcida otras como una espiral, siempre en busca de caminos extraterrestres como las agujas de las catedrales góticas. Esas repeticiones asiduas de palabras y de versos no son sino la angustia que el poeta sintió en el duro trance creador ante la fuga de lo que anhelaba expresar, las redes que le tendió al pez misterioso de lo no expresado todavía para atraparlo en un círculo estratégico" (Vargas Osorio, "Iniciación" 59).
} 
es montada ahora de acuerdo al paradigma de suspensión del contexto habitual de la palabra-materia, y el consiguiente descentramiento de su significación:

Cual Verlaine y Rimbaud, mi Yo pérfido,

Mi Yo cándido: equívoco enigma,

Doble esfinge, dolor prometéico,

Demoníaca lacra, y estigma

Divinal!

Por la landa ambulábamos

Paradigmas, Yo y Yo, de lo dual... (Obras 393-394)

El Yo y otro Yo, ambos, como paradigmas de lo dual, es decir, uno respecto al otro y cada uno respecto a sí mismo: aquí subyace uno de los núcleos de desarticulación fundamentales en el montaje de significaciones de esta poesía. El "paradigma" del Yo dual o desarticulado no es gratuito: apunta a un criterio de creación basado en un tratamiento especial de ese Yo por parte del poeta, y no a criterios de significación previamente dados por la "organicidad" de la poesía tradicional. La técnica de montaje característica de la vanguardia, según Bürger, no responde a un criterio sintagmático de relaciones entre significados, como en la obra de arte "clasicista", sino a un criterio paradigmático, esto es, a una vinculación de los elementos según un modelo estructural (Bürger 144). Como en los textos automáticos, se reconoce un "significado relativamente consistente, aunque no ya sujeto a la búsqueda de

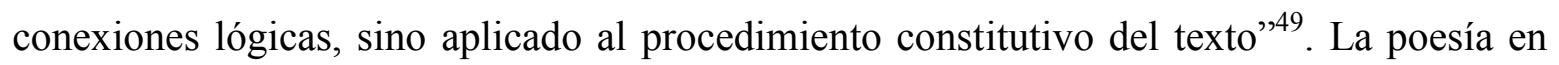
De Greiff está provista de su propio modelo estructural, un modelo que toma distancia de la relación sintagmática de elementos en la poesía tradicional, y hace de la fragmentación y el descentramiento el paradigma de su creación. El acto creador es como el "trágico piélago /

\footnotetext{
${ }^{49}$ Es preciso, de nuevo, delimitar la radicalidad o extensión del procedimiento de "montaje" en De Greiff, pues no es posible, como se ha advertido, aplicar las categorías desarrolladas por Bürger al conjunto entero de su poesía, ni mucho menos. Así como es evidente, en muchos poemas, una fractura del discurso tradicional y la subjetividad que allí se configura, también es innegable que en muchos otros se mantiene intacto el modelo "sintagmático" de la "obra de arte clasicista". La ruptura radical no tiene lugar en todos los poemas que subvierten el orden tradicional de constitución del sujeto; pero existen ejemplos que, sobre la base de una irrupción en apariencia caprichosa de fragmentos - un modelo "paradigmático", no "sintagmático", de la lógica constitutiva del texto-, dan cuenta de una audacia comparable a las negaciones más absolutas de la representatividad del lenguaje en la primera mitad del siglo XX. Después será referido este procedimiento, como lo expone Bürger, no sólo a la configuración de la subjetividad fragmentada, todavía elaborada, a veces, según vínculos de significado tradicionales en la perspectiva de este autor, sino a esos discursos más radicalmente opuestos a la "organicidad" del lenguaje poético tradicional.
} 
que voy surcando yo conmigo mismo" (139), un "piélago vacío" donde "vibra el cuarteto en lamentoso unísono" (187). Es decir, un paradigma del Yo desarticulado. Los contextos habituales del Yo han sido suspendidos. Y al suspenderse la función tradicional del Yo se suspenden también los significados derivados de ese Yo, en concreto, la palabra-materia de los demás Yo en que aquel se fragmenta una y otra vez. Matías Aldecoa es fragmento, pero a su vez se fragmenta en las palabras que lo desarticulan:

\footnotetext{
Yo diría... (palabra de Aldecoa!)

Yo dijera... (palabra de Matías!)

Que en noches y en mañanas y que en días

Loco estás y está el búho!... y no sonrías;

Lo que te digo es formidable loa! (16)
}

No sólo se fragmenta el fragmento ya dado, sino también el día y la cordura y la identidad humana de ese "búho rumiando paradojas" y la intención irónicamente laudatoria derivada en burla. Toda identidad se cuestiona y contradice, y no es posible saber hasta dónde llega la despersonalización. Una vez desarticulado el Yo primigenio -y por tanto la expresión unívoca de significantes-, sus fragmentos sólo pueden ser Yo provisionales. Y al nivel de la expresión vanguardista, ese Yo primigenio no existe, pues su desarticulación $-\mathrm{y}$ la de esa realidad que pretendía articular- es el paradigma mismo de la creación. Esta es la inversión de lo "sintagmático" por lo "paradigmático" en De Greiff. El Yo no se presenta como una entidad homogénea, sino como la reunión de múltiples Yo que entrechocan, y ese conflicto es el parámetro que estructura la creación poética. El Yo contradice al Yo. Semejantes y a la vez diferentes. Uno y otro, paradigmas de lo dual. La anulación de sí mismo, o entre “ellos" mismos, es recurrente: "Y es mi existencia trunca, / porque a todo respóndeme con voz dura y letal / un ser oculto y trágico que dice y dice: nunca...!” (68). No en vano, el poeta se ve a sí mismo -desde fuera de sí mismo-, como "antitético símbolo imprevisto" (145). "Indiferente Hamlet", es "avieso Yago de mí mismo" (219): "Héteme "monstruo de mi laberinto"” (Nova 29). La expresión se revierte contra el sujeto que configura el sentido en el lenguaje, como fragmentos de significantes que se devuelven y lo atraviesan:

Las flechas de mi carcaj

Todellas las he soltado. 
Unas pasaron las nubes,

Otras en tierra quedaron.

Háylas ya por las estrellas

Pechos rompiendo de astros,

Rompiendo constelaciones

Y mundos innominados,

Rompiendo los corazones

De Prociones y Pegasos,

De Sirios y Casiopeas,

Y Altaíres namorados.

Las flechas de mi carcaj

En mi pecho se clavaron. (Obras 159)

La despersonalización no permite establecer con seguridad el lugar de enunciación, como tampoco el destino o la naturaleza de los "significantes". El "acontista" cuya profesión "es hacer disparos al aire" (428) es, al final, el blanco mismo de su enunciación. ¿Qué son entonces Prociones, Pegasos, Sirios, Casiopeas, "Altaíres namorados"?: trozos de significantes derivados de un eventual Yo primigenio o -lo que es lo mismo- de los Yo provisionales. La identidad es un conjunto descentrado de fragmentos, y como tal, éstos no tienen una jerarquía. Las identidades se suspenden al mismo nivel de descontextualización del Yo habitual, y por eso son equidistantes respecto a un centro que no existe. Cada una es un centro, pero cada centro es relativo a sí mismo, al enfoque que hace de los demás. El Yo, por lo tanto, lo es todo, pero al mismo tiempo es provisional. ¿Cuál es la subjetividad central en un Yo descentrado? ¿Es acaso uno de los trozos de identidad que apenas salen a la superficie del lenguaje desaparecen o entran en pugna con los demás? ¿Es acaso De Greiff? Imposible decirlo en términos de subjetivación lírica. Este es uno de los logros fundamentales en De Greiff, la construcción de su Yo como un Yo deconstruido. Un Yo que sólo existe en la medida que, en palabras de Cuartas, se disemina en una escritura de la multiplicidad. La ironía fundamental del Yo: un Yo que al hablar de sí mismo habla de otro Yo. Autonomía y heteronimia del Yo: dos conceptos que son arrastrados y diluidos por el fluir de lo discontinuo, por una escritura entendida "en el sentido derridiano como: espacio abierto, fluyente, diseminante" (Cuartas, "León de Greiff" 117). La ironía es decisiva en 
esta oscilación entre lo construido y lo desarticulado, entre el sujeto sintagmático y el paradigma de la escritura diseminante, entre la centralidad y la provisionalidad de los Yo múltiples. Es en virtud de ella, como señala Cuartas, que el poeta se disemina en otros poetas, pues "la ironía es destructora, choca violentamente la sustancia del Yo creada en la escritura, [...] es confrontación del individuo creador con el lenguaje o con las cosas sensibles por él designadas ${ }^{50}$.

La materia de la escritura en De Greiff es el Yo desarticulado, cuyos fragmentos se montan en superposiciones emergentes e inmediatamente desaparecidas bajo otras configuraciones diferentes. Por su parte, la materia del Yo desarticulado es ni más ni menos que la totalidad del universo girando alrededor de cada centro provisional. Por ello, en este juego de despersonalizaciones, activado una vez para ya nunca detenerse, no es posible saber quién es el verdadero Yo ni dónde están los límites de una autonomía que se ha vertido por completo en el espacio "externo" de la heteronimia. En el universo poético de los centros provisionales, en esta expresión fragmentada de la realidad merced a la discontinuidad del Yo, las identidades son ellas mismas, pero también los “otros" de sus contrarios. Y en el Yo como paradigma de lo dual -ya lo hemos visto-, los "otros" son inseparables del Yo y los contrarios se transforman en semejantes. Sirio y Casiopea son Sirio y Casiopea, pero a la vez son trozos de expresión derivados de la discontinuidad del sujeto lírico. Por lo tanto, estos nombres refieren los múltiples astros agrupados en las constelaciones (derivadas a su vez de nombres mitológicos), pero no por ello son más -ni menos- que palabras expresadas por un sujeto de enunciación. Así, la despersonalización en De Greiff es la clave del lenguaje mismo: la palabra que, al expresarse, fija de manera provisoria sujeto y enunciado en una realidad discontinua que adopta, sin cesar, múltiples configuraciones. La seguridad de lo conocido, en consecuencia, es mínima, pero no así la seguridad del modelo o paradigma creativo de la fragmentación, adoptado para desintegrar una tradición fundada en la unicidad del ser y la expresión unívoca. Frente al "enmarañado tropel” de recuerdos de múltiples personajes y prototipos contradictorios, que son ellos mismos pero también trozos de una subjetividad cambiante no identificable con un Yo único, dice el poeta:

\footnotetext{
${ }^{50}$ Cuartas, “León de Greiff” 133-114. V. págs. 82 y 103 del presente trabajo.
} 
Ninguno yo conozco.

Ninguno.

Y el multánime y el multiforme Yo, lo han sido todos ellos. Y otros más que olvidé.

El multiforme Yo, lo han sido todos ellos: el multánime, dentro mi pequeña anímula; y el multiforme, en la mi diminuta proteidad.

Ninguno yo conozco.

Ninguno ya conozco...

Y otro soy Yo: que se fugaron. (Obras 281)

El siglo XIX, sea centenarista, simbolista o modernista, está definitivamente clausurado. La literatura finisecular y toda su prolongación tardía no se acercaron siquiera a frases como "Los avatares (las avataras?), andares y tomares de algunos de los más conspicuos entre mis Otros-Yóes, sosías, aimones y cacodaimones, que ya van por sobre Ene menos Uno: (yo soy el menos uno)" (574). Tampoco, a implicaciones de textos como la caracterización de Pantonto Bandullo, otra de las muchas identidades fragmentarias del poeta, que se reúne con otro $-\mathrm{u}$ "otros"- de sus Yo provisionales en una de las célebres tertulias evocadas frecuentemente en su obra:

Don Pantonto Bandullo no es un personaje imaginario -en total- pero tampoco es alias reconocido ni seudónimo de particular perencejo. Don Pantonto Bandullo participa de real y de fabuloso, de mítico y de cotidiano, de censado individuo y de insensato engendro pigmaliónico. Suelo verme con él -todas las tardes- en un discreto cafetín de extramuros, como ocurre decirse al ubicarles en los novelones cuando hay muros-. Bandullo y el coronista hoy de turno, entre moka y moka, entre copilla y copilla, se cuentan sus invenciones y mentiras y se las creen, pero no se recitan sus poemillas, porque ahora son bardos en cesación "a divinis" y no la pulsan ni la tañen (alusión a la lira de los liróforos o portaidem). Se ha dado cuenta el coronista, héme dado yo cuenta cabal de que Pantonto Bandullo no es ni tonto ni cabal -en cuanto pinta por descabalado- ni tan ventral, porque es cenceño y enjuto. Descabalado y enteco, pero no peligroso beligerante, como no se aluda a su nariz, ciranesca por antífrasis. Lo romo de su nariz tampoco es cosa del otro mundo. Es un chato como otro, y como es corto de vista -además- no la necesita excesiva para ver más allá de ella. (556-557)

La despersonalización aquí efectuada, llena además del "barroquismo" del que habla Mejía Duque, es más vanguardista que muchos textos ultraístas o expresionistas ligados a una 
idea del sujeto aún estable ${ }^{51}$. En efecto, la depuración del lenguaje a favor de la metáfora, a fin de reforzar el impulso de la expresión o trastocar la percepción del lector, a la manera del ultraísmo o el expresionismo, no implica en sí misma la destrucción del Yo expresivo o perceptivo de experiencia, por muy intensa o disociadora que ésta sea, ya que, justamente, el efecto proviene de la lucha entre el sujeto indivisible y las fuerzas disociadoras de lo irracional. En nuestro caso, esa lucha ya no tiene sentido. El sujeto está desintegrado y la poesía trabaja sobre los fragmentos. La angustia melancólica da paso a la resignificación irónica $^{52}$. La indefinición de primera o tercera persona, en sus formas singular y plural, alrededor del "coronista" y su contertulio, afecta la identidad de quien establece la enunciación. Dividido en "yo", “él”, “nosotros", “ellos”, el poeta habla de sí mismo y de los demás. No hay un sujeto claro de enunciación, pues el "coronista hoy de turno" en principio es nombrado por una indefinida tercera persona, y después asume, en la misma frase y sin advertencia de la modificación, la voz dominante. El juego de voces multiplica los puntos de vista, al modo del montaje cubista al que se refiere Bürger, con la anulación de la unidad en una soledad dual: "Noches en las mesillas del café nocharniego: Cerca a mí, ante las copas, El Otro, mi 'alter ego' [...], su borrada sonrisa, la luz parpadeante de sus ojos inquisitivos” (381). Y además, más allá de esta superposición de identidades, no se puede fijar un sujeto único de enunciación: en efecto, al tratarse de un lenguaje unitario

\footnotetext{
${ }^{51}$ Es cierto que un poema como este, del mamotreto "Bárbara Charanga bajo el signo de Leo", fue publicado en una época más tardía que los anteriores, esto es, hacia mediados del siglo XX. Pero esto, en un análisis que se extiende a toda la producción de De Greiff con el fin de determinar los elementos que lo distancian de la tradición moderna y más concretamente "modernista", vinculándolo a una estética del todo enmarcada en la época contemporánea tanto durante la primera vanguardia como en tiempos posteriores en que ésta continuó desarrollándose de diversas formas, antes que implicar una objeción a los criterios de selección del objeto de estudio, más bien lo es respecto a decenas de posturas que insisten en que este poeta sólo puede comprenderse en virtud de la estética decimonónica de la poesía finisecular. No sólo la evidencia del tiempo transcurrido, sino sobre todo de la estética de la poesía aquí examinada, son poderosas objeciones para desplazar visiones demasiado tradicionalistas aún no descartadas por completo en algunos panoramas analíticos de la literatura colombiana de primera mitad del siglo, y razones de más para insistir en la necesidad de abordar un marco teórico y conceptual de análisis más acorde con problemas estéticos y filosóficos contemporáneos, que contribuyan a determinar mejor los avances y logros de esta obra respecto a la literatura en la actualidad. Esta labor, por supuesto, debe extenderse desde sus primeros mamotretos, enmarcados en la primera vanguardia histórica del continente, hasta los últimos, ligados a esa especie de segunda vanguardia o posvanguardia que continuó planteando interesantes exploraciones formales y temáticas.

52 Por mucho, es una especie de "angustia equilibrada por la ironía", como indica Tomás Vargas Osorio (62), donde las emociones en que el expresionismo trabaja resultan completamente cerebralizadas y revertidas, a veces, hasta el punto de la ridiculización. La ironía, ya se ha visto, es el principio de desintegración del sujeto, y en este caso se antepone a una identidad susceptible de consolidarse a través de la angustia, por medio de la lucha con las fuerzas disociadoras que la generan, siendo esta identidad el fruto de la "necesidad" subjetiva de mantenerse estable. Pero la angustia en De Greiff no es la misma del expresionismo, pues en este caso ya no hay subjetividad única o estable por la cual luchar (v. pág. 114, nota 48, del presente trabajo).
} 
sólo desde lo colectivo, no tiene caso indagar en quién habla o en quién imagina a quién. La definición de sujetos únicos no aplica aquí, pues la provisionalidad es la que rige. El círculo se cierra sobre sí mismo: "Tú, don Nadie" (447); o más todavía: "Y tú -mi Yo-, contigo y mudo soliloquia: / contigo misma siempre, mi soledad ilesa" (501). Los sujetos de enunciación son múltiples y siempre indefinidos. De ese modo, algunas "Prosas de Gaspar" controvierten la supuesta confusión entre Bolombolo y Korpilombolo por parte de este heterónimo, una equivocación que, según el preámbulo de la "Farsa" antes citada -escrito a su vez por alguien "ajeno" a ésta-, lo habría desviado de su búsqueda de los demás elementos del Trío Coautor -Leo y Matías-. Un pie de página -escrito a su vez, también, por alguien "distinto" a Gaspar- asegura, en contradicción con lo dicho por el otro autor indefinido del preámbulo de la Farsa, que "Gaspar, consecuente con su deseo y convencido de que sus camaradas no iban tras el norte, al saber de su fuga de ellos, salió a su caza... por otro lado, yendo a parar y a morir o desaparecer, a Korpilombolo” (268). El propio Gaspar lo confirma más adelante:

La risa que me daría. Cuando pienso en Aldecoa y en Leo, desorientados como un arenque sordo -en su dichosa región de Xenufaná- cavilando, los inocentes, por mi fuga, inquiriendo y pesquisando, los pazguatos, tras la posible meta de mi evasión subrepticia. La risa que me daría, si reír me petara, que no me peta. [...] Matías y Leo, Le Gris y Aldecoa a mi vera, con su lastre de ellos: ése pathos romántico, ésa floresta retórica. Ésa su tarea sensiblera de ellos, ¿será compaginable con la aridez y la mudez, con la adustez y gelidez mías? (293)

Las distintas perspectivas de enunciación - entre ellas las cuestionadas por "románticas", "retóricas", "sensibleras", o de heterónimos ya no sólo del poeta sino ahora de regiones "Xenufaná" por Bolombolo, igual que "Netupiromba" por Bogotá y "Zuyaxiwevo" por Medellín en otros poemas- se multiplican todavía más con el nuevo pie de página que cierra esta "Prosa":

Lo transcrito y un soneto auto-retrato de Gaspar, fue lo último dél recibido. Llegó con una densa epístola (a Budur?, a Deidamía?, a Hipólita?, ya no recuerdo) en la que se despidió de sus compañeras y compañeros. Meses después remitió dos "Relatos de Gaspar". Todo ello vino de Korpilombolo. "The rest is silence". (294) 
¿Quién dice "ya no recuerdo”? ¿Quiénes son Budur, Deidamía, Hipólita, además de esas fuentes literarias que, como se ve con frecuencia, son sólo nuevos nombres de los anteriores nombres multiplicados? De nuevo, es el poeta mismo y todos los "demás". Sólo en los demás, el poeta es él mismo. Más aún, sólo es sí mismo cuando es todos los demás: "Blasón del Egotismo. / ¡De sí mismo el heraldo, el vocero, el acólito!” (Nova 57); el “Epígono de Sí mismo / -del Narciso 'a rebours' (a contrapelo) a carcajadas siempre de su yoísmo-" (58). Se entiende por qué De Greiff es tan múltiple y al mismo tiempo tan único e irrepetible: porque adecúa cada fragmento de existencia, que pasa múltiple y vertiginosa por su poesía como trozos llevados por un torbellino, a un fragmento de su subjetividad. El poeta es el "sí mismo" fragmentado, pero también la existencia en trozos que se manifiesta en esos fragmentos subjetivos, y que ha perdido su seguridad tanto como el mismo sujeto la ha perdido. Las implicaciones de este viraje en la literatura son inquietantes. La crisis de identidad es múltiple. Son tiempos de desobjetivación y desubjetivación. La designificación de la existencia, tanto respecto del sujeto como de la realidad que éste configura en el lenguaje, y por lo tanto, de esa misma realidad. Lo nombrado pierde su estatuto "real", "autónomo". Sólo es un significante más en la inmensa red de significantes en que está atrapado, hasta el extremo de la desintegración, el propio sujeto. Todo es significante, hasta el sujeto mismo. Gómez habla de un "desenfreno" en "inventar nombres y palabras o hacer asombrosas variaciones formales de los existentes", como "signo de una impotencia en la expresión objetiva, el desvío en un mar de aspiraciones inefables y semidelirantes que quieren suplantar el sentido y la hondura con la música formal y el color excesivo" (Gómez 166). La alusión de Cuartas a la escritura en De Greiff "en el sentido derridiano como: espacio abierto, fluyente, diseminante" (Cuartas, "León de Greiff" 117), cobra así una nueva dimensión. Las suplantaciones de sentido que refiere Gómez remiten a esos "suplementos" fundamentales en el pensamiento de Derrida, que reemplazan en el lenguaje la originalidad externa a él. Todo es différance cuando la ruta de enunciación sólo lleva a otras enunciaciones. Los significados se multiplican a medida que la realidad pierde su estabilidad "real". Es lo natural en un sujeto que se maneja con "suplementos" de realidad en la escritura, y que al notarse como "suplemento" él mismo, en una realidad infinitamente “diferida", se funde en últimas en un maremágnum de significaciones: 
Derrida plantea cómo la operación de la différance, más precisamente, la suplementariedad, retarda y difiere la presencia. A esta operación de fisura, división y retardamiento de la originalidad de la presencia atribuye Derrida la différance propiamente, porque la presencia se "completa" en el "suplemento"; la originalidad de la presencia no accede a la historia más que a través de la alteración y el retardamiento operados por el "suplemento". (Cuartas, "Autobiografía" 78)

El modernismo y su subjetivación definida, así como el racionalismo y la misma idea del "sujeto" que la sostiene, ya no son, a estas alturas, más que una nostalgia. Y una nostalgia de anquilosamiento, pues ahora la creación poética debe afrontar la desintegración para poder constituirse. Esa es la poesía en De Greiff, la integración de lo desintegrado, para desintegrarse e integrarse de nuevo, una y otra vez, sin inicio y sin final, del mismo modo que no tiene inicio ni final ninguna de sus rutas de enunciación. No hay lugar definido para el sujeto de la expresión ni destino preciso para la función significante de sus palabras. No hay, por lo tanto, al nivel del lenguaje, ni sujeto ni realidad. Los elementos de la existencia "multánime y multiforme", diseminada en una profusión de nombres provisionales, no son más que funciones inestables del lenguaje, variables de la sub-objetivación, estados momentáneos de la enunciación. Se entiende por qué a veces no es posible saber si el poeta se refiere a otros o a sí mismo: se refiere, en últimas, a esos dos estados de enunciación, "él" y los "otros". La "Señora muerte", poema "a los amigos muertos", se va llevando "todo lo bueno que en nosotros topa", mientras "en un rincón" quedamos "nosotros", los poetas -o fragmentos de subjetividad poética- más censurables para De Greiff, incluido, de modo ambiguo, su Yo lírico -o fragmentos de su Yo lírico-. Igual que un contertulio es muchos contertulios, un poeta también es muchos poetas. La poesía proviene de diversas fuentes, integradas provisionalmente en una personalidad escindida: "Es mi placer -Noé solo en el Arca- / ;fabricar humo en cualque de mis pipas!” (Obras 478). Esa parece ser la clave de la serie de personajes de la "Farsa", que según lo dicho, en parte pueden ser integrantes de "Los Panidas" - grupo temprano del poeta que es mencionado en el poema-, y en parte fragmentos de su Yo lírico:

Con lo cual se fina

Esta poemática

Fantasista farsa grotesca 
[...]

Con lo cual (uf!) se fina;

Pues los pingüinos ante la kilométrica

Perspectiva filosófica

O pseudo; -perspectiva un poco mucho tétrica-

Armaron un de Agramante: una guasábara

Tropical, catastrófica

Que registraron los T. S. H. de la frontera bávara-,

Y huyeron hacia el Polo

-Norte o Sur, yo no sé--,

$[\ldots]$

Y huyeron hacia el Polo

Yermo y frío.

Y yo me quedé solo.

Solo.

Solo.

Solo

Y mío. (124)

La huida al Polo, "Norte o Sur, yo no sé", no puede menos que evocar, desde una mirada amplia de esta obra, la huida de Gaspar: "Oh amigos, vámos al Norte, vámos al Norte...!, aunque sea dando la vuelta por el Sur". En el juego de las identidades convergentes todo es posible. Y lo es, porque De Greiff ha identificado el todo -o la "nada"- con él mismo, con "la callada sibila de sus pupilas verdes y gríseas [de su espíritu] que a Todo dicen: Nada",53.

53 Obras 381 . Respecto a esta confusión devenida en acertijo, estos extensos espacios referenciales dentro de
los cuales "León es un falso solitario", dice Germán Arciniegas: "Quien diga que puede seguir el laberíntico
embrujo de los viajes de León en sus tres mundos ['la isla de Antioquia de sus experiencias, la península
Escandinavia de su imaginación' y 'el de su vida total, el de la sociedad en que ha pasado lo mejor de sus
días'], en la narrativa, sabiéndolo todo, es un ingenuo. El poemario del poeta es un diario íntimo lleno de
señas, indicios, seudónimos, remoquetes, secretos, alusiones tapadas, que despistan al más astuto, al mejor
documentado. Los trece Panidas, del grupo original que se reunía en la tertulia de Medellín, circulan por todos
los poemas con nombres diversos. La vida ha venido multiplicando esos nombres por trece veces trece -y
otros tantos- y reducido la cifra de los íntimos en igual proporción. Y como cada uno va dejando su
testimonio en el poemario, el crucigrama se hace rompecabezas" (Arciniegas 75). En esta situación, en que
"el propio León se llama de cuarenta modos" (73), no es posible definir o diferenciar identidad alguna. El
poeta cubano Luis Suardíaz, haciendo eco a esta especie de sentido del disfraz, decía que De Greiff es
"siempre difícil de agarrar, de situar, de clasificar, pues no sólo tiene varios nombres como trajes y camisas
para cada ocasión, sino también varias voces" (Suardíaz 126). En tal circunstancia, sólo es posible afirmar, 
La soledad suele asociarse, entonces, a la convergencia de numerosas subjetividades, y la reunión de éstas se asocia, en correspondencia, con la soledad: "Pupila faceciosa con que miro $[\ldots]$ a los hombres como hermanos; a los hermanos como amigos; a los amigos como desdoblamientos de mi Yo" (296). Es clara la ironía en estos desdoblamientos, pues se advierte la presencia de la "facecia" ${ }^{54}$. Mas no por ello, en el poema, el Yo deja de formar dualidad -o dualidades - con otro Yo, así todo esté modulado por la ironía, del mismo modo que lo está en toda la obra del poeta. El "hombre que disfrutaba la soledad a sus anchas" (Rojas de la Espriella 17), disfruta mucho más de desintegrarla a sus anchas. Y el espacio de su lúdica creativa es ese círculo antitético donde se encuentra a sí mismo, una y otra vez, "buscando, buscando... / lo que nunca encuentro / por fuera de mí!" (De Greiff, Obras 11). La "Admonición a los impertinentes" retoma esa convergencia de soledad y multitud de subjetividades, con una ironía que, como dice Cuartas, no es un procedimiento más de esta escritura sino, por el contrario, la materia que la conforma, esa misma que desnaturaliza la retórica modernista de la autosuficiencia, que "arredra la individuación del autor en la escritura, representando al mismo tiempo tanto su humanismo inalterable como su aprisionamiento en las redes del tedio y la melancolía" (Cuartas, "León de Greiff" 114); en fin, una ironía que, como factor de desintegración del sujeto, es el paradigma la de creación en este montaje de múltiples subjetividades, a través de la cual el poeta, en su proclama de soledad libertaria, se vale de muchos calificativos para definirse a sí mismo en la alteridad que lo conforma:

Como yo soy el Solitario,

Como yo soy el Taciturno,

Como yo soy el Hosco, el Arbitrario,

Como soy el Lucífugo, el Nocturno,

una y otra vez, que la escritura del poeta es la fragmentación de las subjetividades que surgen, de cualquier manera y con origen "real" o "imaginario", en su personalidad siempre mutable, desafiando así la idea de las identidades unívocas tan vigente y aceptada, sin más, en muchos ámbitos de la tradición de la modernidad.

${ }^{54}$ Aquí se revela la diferencia entre la diseminación subjetiva en De Greiff y la falacia romántica -todavía no extirpada del todo en la poesía finisecular-, por la cual el sujeto nombra al universo en función de su propio Yo, pretendiendo que ese Yo permanece invariable y es lo bastante sólido para abarcar, sin desvirtuar su identidad, la totalidad de la existencia. La frase anterior a la arriba citada así lo corrobora, con la advertencia de lo "facecioso": "Pupila faceciosa con que miro al mundo acerbo como campo floral, lustral, deleitable, multivario; como campo de nobilísimos torneos". La ironía es patente, pese a que ciertas palabras típicamente "degreiffianas" parezcan invalidarla, pues la escritura misma no es más que ironía en un discurso sobre la pereza que comienza con su propia anulación: "Oh cuánta pereza dame escribir tu elogio, disminuír tu elogio, pereza, pereza hermana, compañera mía, pereza amante!” (Obras 295). 
Dejadme solo.

Como soy Leo Atrabiliario,

Como soy Sergio el Estepario,

Como soy Proclo Extravagario,

Dejadme solo. No quiero compaña.

Dejadme esquivo. Non gusto coreo.

Sergio Estepario, Estrafalario Leo.

Con mi tonel. De mi cruz cirineo.

Rey de Burlas, soberbio: cetro o caña

Pares le son a mi elación huraña.

Dejadme solo. ${ }^{55}$

Los calificativos abundan, como las personalidades que se suceden en esta autodefinición: además de lo anterior, el poeta es judeo, quechua, orangutánida, ario, estirpe de Saturno, decantador de canto silencioso, alquimista señero, juglar oculto, absconto fabulante, catador, tañedor, alto cantor, bajo cantante, soplador de caña silvestre, no adamado ni sigisbeo, áspero, másculo, rudo, sin plaña, sin queja, más mudo que Beethoven sordo, sin laude, más zurdo que Cervantes manco, sin "pathos", más seco que no Falstaff gordo, solitario, adusto, único a bordo, espíritu en negro, corazón en blanco, "notas-arranco", "fábulas-bordo", "facecias-urdo", señero, jamás desbordado (Obras 492-493). Todos son "otros" y "él mismo" para el sujeto: cirineos de su propia cruz. La soledad en medio de un universo de múltiples identidades, ciertamente, sólo es nominal. Se anula a sí misma, como "mi soledad sahumada de recuerdos y asesinada de Imposible" (184), ligada al "fardo de los recuerdos" de años también "saturados de recuerdos y asesinados de Imposible" (186,

\footnotetext{
${ }^{55}$ Obras 493. Ciertamente, la proclama de distanciamiento social es de índole finisecular y modernista, pero incluso este elemento no comporta aquí, en exclusiva, el contraste entre un arte autónomo y los ámbitos prosaicos de la realidad en la que se inscribe, pues el refugiado de la torre de marfil es bien diferente, claramente, del taciturno arbitrario que recorre la estepa "con mi tonel. De mi cruz cirineo". La ironía ha desacralizado la poesía y el vagabundo delirante sustituye al sacerdote que oficiaba la comunión con el universo mediante el símbolo poético y las correspondencias. En De Greiff hay un distanciamiento, pero no sólo frente a ámbitos "prosaicos" de la sociedad (de los cuales, sin embargo, también poetiza a la hora de lanzar sus críticas, en un ademán muy poco simbolista, como en el poema a la "ferroviaria descarrilosis" del "tropical ferrocarril, fruto del mal ingenieril"), sino también frente a concepciones demasiado solemnes de la poesía -como se ha visto antes en este trabajo-, las cuales son, en realidad, el objeto constante de su crítica: el "Rey de Burlas", para quien da igual el cetro o la caña, es el primer y más encarnizado burlador de sí mismo.
} 
187). La visión de esta soledad implica el desdoblamiento de quien se percibe a sí mismo como un Yo conformado por una multitud desordenada y contradictoria, la representación carnavalesca de un sujeto filtrado a través de interminables redes de enumeración, esto es, de integraciones momentáneas de lo pulverizado: "Pasa la lívida caravana retrospectiva, [...] global conjunto del desarrollo cogitante / al través de los días definitivamente muertos, / al través de los días ya muertos y vivos y actuales [...]. De lo durable y de lo transitorio abolidos!” (186-187). Pero en la comparsa de los contrarios abolidos, también es nominal esa multitud donde se aglomeran las proyecciones de la subjetividad individual. La soledad "asesinada de Imposible" no excluye la "soledad ilesa" antes citada. Ni la unicidad es "una sola", ni la multiplicidad está totalmente desvinculada en su interior. Todo puede ser más "uno" y a la vez seguir multiplicándose. Los fragmentos de fragmentos de la individualidad entran así, entonces, en el juego de despersonalización que, sin embargo, se desarrolla alrededor de un centro provisional desde donde se desintegran, reintegran y vuelven a desintegrarse los trozos múltiples del Yo:

No he visto el mar.

Mis ojos

-Vigías horadantes, fantásticas luciérnagas;

Mis ojos avizores entre la noche; dueños

De la estrellada comba;

De los astrales mundos;

Mis ojos errabundos

Familiares del hórrido vértigo del abismo;

Mis ojos acerados de viking, oteantes;

Mis ojos vagabundos

No han visto el mar... (54)

Sujeto y realidad coinciden en la fragmentación. Quien habla se identifica con lo hablado, así como los ojos con aquello que ven. Y hasta con lo que no ven. No importa. Es igual. Todo es un atributo de la unidad dispersa. La escritura disocia el Yo y el cansancio, sólo para volver a integrarlos: Que duerma muy largo mi / Cansancio. / Yo con él: (oh Noche! por siempre durmamos: / Mañana ni Nunca ven a despertarnos!" (213). Y no sólo unicidad y multiplicidad son meramente nominales. Todo lo es en esta escritura de la diseminación, 
de la différance de significación: "todo es falso", "todo verdad", "todo existe y no existe", soledad y aglomeración, lo individual y lo colectivo. Son claras las implicaciones de lo "uno y múltiple" con que Cobo Borda se refiere a esta obra (Cobo Borda 59). El sujeto está diseminado desde el comienzo, nace fragmentado, como figuras de la "Danza de la Única y de la Múltiple Dea" (383). En ello radica su posibilidad de identificarse con fragmentos de un universo que ya no pueden integrarse en una enunciación unívoca y estable. Sujeto y universo se diseminan en el lenguaje. En ese nivel, son homologables. La realidad se desintegra en el lenguaje, y el sujeto de la escritura se disemina, por tanto, en la realidad. “Oh lejana y tan dentro de mí” (25): este verso, cantado a una ilusión evocada en un poema, podría ser el estribillo de una relación de indefinición con la realidad a través de la palabra. Lo mismo en esos versos que desgarran al sujeto entre sus ilusiones, formas variables de sus alteridades:

Venías de tan lejos que ya olvidé tu nombre.

Venías de tan lejos... Mejor que no llegaras,

Mejor que te quedaras...: llegabas de mí mismo

Mejor que no advinieras: te nutría mi abismo.

Venías de tan lejos... Venías de tan lejos si estás en mí incrustada,

Si estás en mí clavada, como lo estoy en ti...

Si en mi boca te fundes - dorada golosina-,

Si en tus labios me vuelco -señero, áspero, esquivo-.

Venías de tan lejos... Yo te llamaba Aglaya mirtocleia,

Fulvia Tranqüila... Eunóe, Constanza, Alda, Hila, Iseo...

Yo te llamaba..., cuando apareciste:

Cuando llegaste a mí, como a mí te llegaste, ya no te dije sino Mía $(677,684,686)$.

La segunda persona es clara, pero no así la distancia que la separa de la primera persona, tomada ésta como lugar de enunciación. Hay disolución de límites entre los sujetos que participan en el enunciado. Al integrarse a la escritura, se hacen indefinidos, o si se quiere, se desintegran. El movimiento es contradictorio, se anula a sí mismo, como -ya lo vimos- 
el propio paradigma de esta poesía, su modelo estructural: desintegración en la integración. El sujeto, entonces, no está sólo dentro de sí mismo, sino también en la alteridad ("llegabas de mí mismo", "te nutría mi abismo", "si estás en mí clavada, como lo estoy en ti”). Más aún, sólo existe como alteridad. Cruzada esta frontera hacia la exterioridad heterónoma, sujeto es realidad y realidad es sujeto. No hay límites. Incluso, los nombres o sustantivos mismos que deberían establecer esos límites, más que fijar un sentido lo convierten, en virtud de su irrupción abundante en todo De Greiff, en no único, en variable y provisional. Igual que con los "pingüinos peripatéticos" de la Farsa, en "Los cinco poetas Reyes Magos” el poeta habla de sí mismo al hablar de realidades "más allá” de él:

Entrábase en materia la vez pasada, parecía... Ya se había escandido la primera terna de los de la estirpe del Poeta Rey Mago, Gaspar: Dante, Milton y Goethe, a saber:

Son de la estirpe del Poeta Rey Mago Ebenezer: Shakespeare, Cervantes y Heine; de la del Muy Alto Señor el Poeta Rey Mago Altaír: Villon, Poe y Baudelaire; de la estirpe de Melchor: Hugo, Whitman y y el Innominado o el que está siempre aún por nacer.

De la de Baltasur, todos los infrapoetas, toda la morralla zurrapesca poetisoide (y somos Legión!) donde enfila el fallido séquito de Orfeo -su bestiario-: hijos nunca de Apolo; talvez o quizabes ni del buen Baltasur; clasificando por especies, son de la estirpe de Baltasur: (a): El Retórico, El Adocenado, El Gramatista; (b): En SinEstro, El ANumen, El Pampirólico; (c): El Simulador, el Viento en Popa Soplaviento, y El Yo También Por Qué No He De Hacer Como Que Hago Versos?

Por ahora, Punto. Breve pausa. Recapitulación. (564)

El sujeto es muchos porque todos son él en concreto, y sólo puede ser él mismo al configurarse a partir de ellos. Responde al llamado de "vamos presto los del alma mesta" (183). En la "Balada trivial de los 13 Panidas", éstos parecen ser, como en la "farsa" ya citada, la síntesis de contradicciones del poeta, el conjunto de pretextos en que distribuye sus propias singularidades, reuniéndolas, como contertulios, alrededor de una mesa:

Fumívoros y cafeístas

Y bebedores musagetas!

Grandilocuentes, camorristas,

Crispines de elásticas tretas; 
Inconsolables, optimistas,

O indiferentes - si os parece-

En nuestros Sábbats liturgistas

Los Panidas éramos trece! (34)

Y la desintegración de la indivisibilidad es en doble vía. Así, de modo inverso, hay un Yo liberado de sí mismo que no cesa de profundizar en su desdoblamiento: "Cantaba. / Él mismo no se oía / la canción que cantaba" (207); o bien: "Una vez me di, / a interrogar la Esfinge, / mi Esfinge interior / [...] / Esa vez oyó / palabras llenas de misterio / y muerte, mi Yo" (133); o también: "Sus sones / tomó el viento, y cantándolas huía: / [...] Yo no sé dónde el viento las oyó, / si no las urdí yo" (436-437); o más aún, al cierre de un poema anterior: "Te fuiste de tan hondo que ya olvidé tu nombre..." (686). A estas alturas, la convicción es clara, explícita: "Unidad es multánime, varia, dispersa, unánime, no única. / Algo más y algo menos: qué alud de angustias, qué irrumpir de trenos" (495). En palabras típicamente "degreiffianas", cada elemento de la enunciación es justamente aquello: "algo más y algo menos". Sujeto y realidad diseminados en el lenguaje, una mutua disolución sintetizada en el canto a la "Noche Múltiple”, una de las páginas más célebres del poeta:

Yo te amaré con amor infinito,

Noche Eterna;

Yo te amaré con amor transitorio,

Noche en Fuga;

Yo te amaré con seráfico amor,

Noche Virgen;

Yo te amaré con amor turbulento,

Noche en Ascuas;

Yo te amaré con amor cerebral, inmaterial, fosforescente, irradiante,

Oh Noche Metafísica;

Bajo la rósea luz de Venus incendiada,

Yo te amaré, Noche Insaciable;

Yo te amaré bajo la advocación de la romántica Selene,

Noche Diana;

Pérfido te amaré,

Noche proclive;

Yo tempestuoso te amaré, 
Noche Vortiginosa;

Yo te amaré glacial,

Noche Fría;

Yo te amaré furtivo,

Noche Cauta;

Yo te amaré cantando a gritos mi pasión,

Noche Desafiante;

Tácito te amaré,

Noche Muda.

Has de acoger mi espíritu y mi cuerpo,

Mi sangre, mi corazón, todo mi ser

-Múltiples-, Noche Múltiple;

Mi espíritu y mi cuerpo, mi sangre, mi corazón, todo mi ser,

-Únicos-, Noche Única,

Noche, Noche Elegida... i (349-350)

Sujeto y realidad se evidencian como estados funcionales del lenguaje, como momentos en el fluir discontinuo de la enunciación. La realidad pierde su condición "heterónoma" de objeto externo al sujeto, pues éste ya no constituye un punto de referencia estable para concebir esa exterioridad. Desgarrado en el lenguaje, el sujeto pierde su univocidad. La multiplicidad de subjetividades impugna la unilateralidad del Yo en su contexto habitual. El estatuto del sujeto se modifica. El lenguaje diseminado es el único y verdadero Yo. No hay más sujeto que aquel que se construye en la escritura, pero la escritura es la diseminación de la subjetividad en múltiples fragmentos. No hay un círculo hermenéutico en esto. Las partes y el todo no se vinculan armónicamente, de modo sintagmático, pues ésta es una escritura que los desborda, que genera con cada parte un todo diferente, y así es revertida la posibilidad del sujeto unívoco. Al hablar de un anónimo poeta heterónimo, De Greiff habla nada menos que de su propio sujeto de la escritura, con todas sus indefiniciones de número y persona, con sus multiformidades y contradicciones:

Tocaba ya los lindes de la treintena cuando le conocí, si acaso le conociera: porque si claro - de una diafanidad desconcertante-, si desnudo de artificios, sin recovecos ni subfondos (tal vez por ello mismo), harto difícil resultábame -en su carencia de complejidades- desentrañar el raro prisma iridiscente de su espíritu radiante, la fuente soterraña de su frenada emoción, lista a irrumpir 
avasallante, en desbordarse frenético, para luego tornar a su pozo ataráxico, velado de penumbra nemorosa, a su rincón de abúlica acinesia: rincón de olvido que adensaba de músicas si su crwth retañía, que poblaba de ensueños su desbridada furia poética -dichosamente frecuente harto poco en demasía-, y que enrarecía su pasión metafísica, hasta tornar su rincón o cubil, campana al vacío, huésped sólo de sí, Buda cogitabundo.

Buda cogitabundo, si no Dyonisos desaforado; toso exultante impulso periférico. Fervoroso, furente, ávido, insaturable, cuando no claudicante entelequia de perfección vegetativa; cansada sombra sin deseos; función de indiferencia y desamor y desdén trascendental: que así tal parecía. Y sin embargo...

Y sin embargo yo vacilaría.

Pero nada puedo decir. No es tiempo aún. Ni a nadie importa. Ni a mí -Gaspar-, ni a ti.

Mucho menos a él mismo. (300-301)

La indefinición es múltiple: del enunciador y de lo enunciado, de una ruta de enunciación que parece devolverse sobre sí misma y contradecirse. Es una ruta de enunciación que sigue las huellas de Hárald el Obscuro: "Todos los viajes, todos mis viajes, son viajes de regreso" (423). Al negar el sujeto unívoco, e incluso su autonomía, constituida en el lenguaje, ante todo, mediante la diferenciación de la heteronomía de lo "externo", De Greiff radicaliza su crítica al lugar de enunciación propio de una tradición literaria que se prolonga hasta el siglo XIX. La modernidad se ve confrontada en su base fundamental de diferenciación entre el sujeto y el objeto por una escritura que trastoca límites entre identidades, tanto de la univocidad del Yo a merced de múltiples subjetividades que lo desintegran, como de la entidad plenamente diferenciada de esta subjetividad frente a otros elementos de la realidad de la cual forma parte. Se trata, ni más ni menos, de aquello que Christoph Menke define como "trabajo de descomposición, al que la experiencia estética somete el funcionamiento de los otros modos de discurso" (Menke 19), asociado a la idea de soberanía del arte en la vanguardia histórica. La clasificación errónea de De Greiff en el modernismo, sin más reservas, es entonces -en una perspectiva amplia de su poética, tan múltiple como su Yo lírico descentrado- la interpretación unilateral de un centro solamente provisional, el enfoque analítico sólo verdadero según la relatividad que a esa identidad estilística concreta, abocada por momentos a la poesía finisecular, le corresponde. La tesis se cae como se caen las unilateralidades en la obra misma del poeta: bajo la irrupción de otras 
identidades que disuelven momentáneamente las anteriores, para derribarse a su vez bajo otras que van surgiendo. Estas identidades aparecen a cada instante, pero no por ello clausuran definitivamente, ni mucho menos, las demás en general ni las anteriores en particular. Por ello, una totalización estilística no sólo indica el claro desconocimiento de la extensa y muy singular obra del poeta - de algún modo comprensible por esa misma extensión y singularidad-, sino que ignora uno de sus mayores logros, la disolución de una totalidad o univocidad subjetiva, y por tanto argumentativa, que choca de frente con la tradición del sujeto autónomo de la poesía finisecular. La multiformidad de esta poesía no admite, en efecto, un veredicto sobre su estética que no contemple en principio la paradoja de lo uno y múltiple, explícitamente desarrollada por el poeta en todos sus "mamotretos". Esta convicción hace justicia a las "multánimes almas que hay en mí", y ciertamente se adecúa más a esta estética que la simpleza conceptual demasiado tradicionalista e incapaz de percibir en su obra las tensiones fundamentales en las que se basa. La fragmentación del sujeto y su expresión en la escritura es un proceso que afecta no sólo al lugar de enunciación de ese sujeto ya descentrado, sino que a partir de éste supera la estética modernista y se inscribe en tendencias de avanzada que no pueden ser satisfactoriamente definidas desde parámetros críticos propios de la poesía finisecular.

Si bien De Greiff no habló de sus múltiples identidades como "heterónimos", no hay duda de que esta categoría se aproxima más al carácter de todas ellas que el insuficiente y de todos modos inapropiado "seudónimos". En efecto, no se advierte aquí la intención de esconder la "verdadera" identidad tras un nombre que desvía la atención de la persona física del poeta, sino la intención explícita de dividir la personalidad en multitud de nombres que surgen, chocan entre sí y desaparecen. Pero incluso el vocablo "heterónimos" adolece todavía de una definición más o menos estable de personalidades, acorde con los famosos heterónimos, después popularizados, de Fernando Pessoa. En este poeta, las identidades son claramente definidas en su personalidad, sin disolverse una en la otra como sucede en De Greiff. Los heterónimos en De Greiff surgen con su propia caracterización, pero no por ello se limitan a ser ellos mismos de una vez y para siempre. Por el contrario, se vinculan sin interrupción unos con otros, se expresan para anularse de inmediato y resurgir al anular a los anteriores. Y la desintegración subjetiva no se efectúa en exclusiva 
con base en el procedimiento de nombrar para caracterizar. La multiplicidad también se distribuye en sujetos anónimos que en las incesantes metamorfosis vertiginosas -“vate en hervorosa actividad" (299) - no alcanzan a constituirse en presencia sustantiva definida. Y en la multiformidad "hervorosa" todo esto se integra contradictoriamente, se desintegra y vuelve a integrarse. Por ello, las implicaciones de los "heterónimos", categoría de estabilización de identidades múltiples pero no fusionables, tradicionalmente ligada a Pessoa, parecen quedarse cortas para definir esta otra condición supremamente dinámica, mutante, autorrenovable, tal como la hemos entendido y desarrollado a lo largo de todo este capítulo $^{56}$. Más adecuado parece ser, entonces, un término empleado, ahora sí, por el propio De Greiff, que implica desdoblamiento, desintegración, posterior integración, contradicción y dinamización de lo fragmentario: en lugar de heterónimos, o mucho menos seudónimos, aquí se puede hablar de "avatares" del Yo. Los avatares en De Greiff -o "avataras", es decir, "andares y tomares de algunos de los más conspicuos entre mis Otros-Yóes, sosías, aimones y cacodaimones" (574) - implican no sólo un sujeto fragmentado en trozos de identidad, sino también, y sobre todo, un proceso incesante de transformación e imbricación de esas identidades, afectadas por las vicisitudes de un sujeto discontinuo. No sólo hay Leo, Gaspar, Matías, Pantonto, Beremundo, Skalde, Hárald, Sergio Stepanski, Ramón Antigua, Erik Fjordson, Míster Grey, Proclo Extravagario, Claudio Monteflavo, Lope de Aguinaga, Gunar Tremholt, Guillaume de Lorges, Bogislao von Greiff, Miguel Zuláibar, Diego de Estúñiga, Alipio Falopio, Baruch, Palamedes, Dídimo el Máximo,

\footnotetext{
${ }^{56}$ Por ello, se equivoca Miguel Gomes al querer asociar del todo el procedimiento de la fragmentación subjetiva en De Greiff con la estética modernista, con base en ejemplos de "seudonimia" de allí provenientes, y desvincularlos en consecuencia de una estética de vanguardia. En De Greiff no hay simples "seudónimos", y ni siquiera "heterónimos" en el sentido de Pessoa (aquí es más correcta, entonces, su distinción entre los dos poetas), pues, como se ha formulado en el texto, la técnica de desubjetivación en De Greiff va más allá de la mera división y alcanza niveles sin precedentes en la poética finisecular. El empeño de Gomes en desvirtuar las cualidades vanguardistas en De Greiff no logra así concretarse, pese a lo loable de su intento -aquí plenamente compartido y puesto en práctica- por "insistir en la necesidad de que se relativice la identificación simplista de León de Greiff con el vanguardismo", la cual descansaría "más en una confianza acrítica en las cronologías que en una discusión de las estrategias verbales del autor y el componente teórico de su escritura, aquello que suele denominarse "poética" (435). Es preciso corregir el simplismo de muchas identificaciones apresuradas y derivadas de ideas demasiado lineales de la historia, es cierto; pero para ello no se requiere negar de plano la condición vanguardista de ciertos procedimientos en De Greiff, como crítica a la tradición literaria basada en modificaciones del material artístico, cayendo así, por lo demás, en el mismo acriticismo que se denuncia. Por el contrario, hay que profundizar en el análisis y encontrar las relaciones concretas entre esos procedimientos y la crítica a la tradición intelectual dominante, en aras de identificar lo que se retoma sin mayor conflicto - lo hay, sin duda-, y lo que supone en cambio una verdadera confrontación de ideas fundamentales en la literatura precedente, como en este caso, el sujeto unívoco y su configuración estable en la escritura.
} 
Apolodoro, el Cabatacaulesista, Abdenagodonosor el Tartajoso o Tartamudo, etc., sino también esos sujetos colectivos, como el "Trío Coautor" de la "Farsa de los pingüinos peripatéticos", que se integran por momentos para desintegrarse un instante después en un discurrir al azar, sin rumbo alguno. Más aún: además de esas identidades parcialmente configuradas y sus integraciones momentáneas en esta escritura diseminada, hay otras identidades que, como vimos, no llegan a ser nombres definidos, sino más bien avances fugaces de tendencias desgarradoras del Yo, de la primera, segunda y tercera persona, de lo singular y lo plural, del sujeto enunciador y la realidad enunciada, todos los cuales "ya van por sobre Ene menos Uno: (yo soy el menos uno)”. La escritura del poeta es entonces su propia identidad discontinua sometida a los avatares del Yo, a las vicisitudes de su conformación. Por otra parte, ¿qué escritura no lo es? Por lo menos, ¿qué escritura o lenguaje puede eludir este problema de definición en la contemporaneidad? Los avatares del Yo son los avatares de la escritura y el lenguaje en una tradición de enunciación que ha denunciado su excesiva filiación idealista. En un reino de significaciones provisionales, un espacio descentrado de componentes de la enunciación, no existe sujeto autónomo ni dominio de la naturaleza por el concepto. Estas ideas de excesiva e ingenua definición sucumben ante la irrupción de una escritura poderosa que todo lo subyuga. El único Yo que aún es posible se conforma en esta escritura, pero está más allá de la idea del sujeto unívoco desde donde se pretendía convertirlo en una facultad autónoma. El Yo es la anulación del Yo ilustrado o racionalista, idealista o romántico. Del Yo de la tradición decimonónica, en suma. Ahora es un Yo formado por los avatares del sujeto descentrado. El Yo de las vicisitudes de identidad. Un Yo que no es Yo. Como la Unidad: "multánime, varia, dispersa, unánime, no única. Algo más y algo menos". El "Ene menos Uno", donde la idea misma de la identidad es el menos uno. Nada más. Y nada menos.

La escritura de la designificación controvierte la tradición enunciativa de siglos anteriores y nos sitúa ante el vértigo de una palabra "hervorosa", plenamente subversiva. Estos estados fugaces de la enunciación son los que generan la posibilidad de "ser" y "no ser" a un mismo tiempo, de invertir las funciones comunicativas de los sujetos designados, de convertir la escritura en un espacio de fuerzas que derriban todas nuestras ilusiones de identidad. El sujeto ha sido destruido. Los avatares dominan la realidad discontinua. Ya no 
hay seguridades, sólo integraciones y desintegraciones, el juego escritural de las múltiples indefiniciones. 


\section{CODA:}

\section{LA CATEGORÍA HISTÓRICA DE LA VANGUARDIA EN LEÓN DE GREIFF}

Tras insistirse por mucho tiempo en el carácter modernista de la poesía de León de Greiff, en los últimos años ha habido un desplazamiento de esa perspectiva a favor de otra que reconoce y da mayor importancia a su carácter vanguardista. No obstante, para la crítica aún no ha sido del todo claro cómo participa el poeta en esa vanguardia, entre otras razones porque no hay mucho consenso en qué es o a qué se refiere en concreto esta denominación en el país o el continente. Para hablar de la vanguardia en De Greiff y precisar su eventual crítica integral al sistema literario -como define Bürger esta corriente histórica-, o su intento de "desplazar el centro del campo intelectual que le es previo", en palabras de Sarlo sobre la vanguardia (222), hay que analizar antes las categorías usadas en tal clasificación y determinar si corresponden a un verdadero carácter de avanzada respecto a conceptos y prácticas institucionales de un medio intelectual, artístico y literario fundado en la tradición moderna, según la noción de vanguardia, en sentido general, de autores muy diversos e incluso opuestos entre sí. En principio, podemos abordar la categoría de "nuevo" con que se llamó a sí mismo el grupo al que el poeta perteneció -palabra tan generalizada como indefinida cuando se convierte en sustantivo denominador de procesos históricos-, así como la posición teórica adoptada por la crítica al momento de referirse a él como poeta vanguardista y de establecer en qué consiste esa vanguardia, tanto en Colombia como en Latinoamérica.

En su texto sobre Los Nuevos y la vanguardia en Colombia, Estripeaut Bourjac concibe al heterogéneo grupo de escritores, artistas y políticos como un factor de disgregación de una cultura estática de orden conservador y más en concreto señorial. En medio de una sociedad

de tradiciones heredadas, Los Nuevos "proclaman su voluntad de forjarse una identidad negando la que proponen las condiciones socio-históricas", a través de una especie de 
"negación de su genealogía" que los convierte en "huérfanos de pasado y de historia"57. La ruptura "generacional" - categoría aludida por el grupo y retomada por la autora con mayor profundidad- se proclama frente a escuelas literarias y partidos políticos contemporáneos que prolongan la tradición intelectual de un "mundo agónico y decrépito" sumido en un "Pudridero" $"$. Las consignas de combate son incuestionables, pero no el modo en que se concretan dentro de esa tradición que pretenden combatir. Desde Alberto Lleras -más tarde presidente de la nación y convertido en "acérrimo combatiente de lo nuevo"- hasta Rafael Maya -que saluda a "su Grecia de estampa satinada",59-, la mayoría de integrantes de este heterogéneo grupo de políticos y escritores en su mayoría fieles a poéticas decimonónicas, pese a crear un hito ideológico fundamental, no consumó en sus prácticas artísticas, y ni siquiera políticas en niveles ulteriores, las premisas más bien indefinidas que lanzaron. En materia literaria, sin embargo, es claro que aquí se desarrolló el núcleo principal de lo que se ha llamado vanguardia literaria en Colombia: León de Greiff, Luis Vidales y en cierta medida Luis Tejada. En el esquema del "tiempo fijado" y del "espacio protector y controlado de la generación del Centenario" (Estripeaut Bourjac 742), como aislamiento de una clase señorial "que se da el lujo de vivir de espaldas a los siete y medio millones restantes de colombianos" ${ }^{\wedge 0}$, De Greiff y Vidales, principalmente, antepusieron conceptos e imágenes transgresoras, que en el caso del primero llamaron a "espacios ilimitados" y

\footnotetext{
${ }^{57}$ Estripeaut Bourjac 738. La declaración de Los Nuevos, escrita por Alberto Lleras y citada por la autora, es clara respecto al intento de desligarse de una tradición en que no tendrían precedentes: "No hemos temido desvincularnos con el pasado para lanzarnos a las nuevas corrientes. Y sin raíces en nuestra historia patria salimos adelante buscando siempre un viento más, una forma nueva, una fórmula más exacta, siempre mirando adelante" (738). Por supuesto, ese intento de desligarse de la tradición, en una visión más actual, es sólo la convicción de que ésta debe ser revaluada en un sentido amplio y que quienes así lo entienden se conciben a sí mismos como los llamados a hacerlo, pero siempre en el marco de esa tradición. Como señala Sarlo, "la ruptura aparece vinculada con la extensión y desarrollo del campo intelectual, cuya legalidad la vanguardia niega. La consolidación y el prestigio de la tradición cultural crean, paradójicamente, la fuerza de su vanguardia. [...] el campo intelectual genera su vanguardia y las formas de la ruptura entran en sistema con las modalidades de la vida literaria preexistentes. El cambio ideológico-estético no se produce en un vacío social, sino que, por el contrario, encuentra en las formas sociales de la producción literaria sus condiciones de realización" (Sarlo 212).

${ }^{58}$ Estripeaut Bourjac 738. El símbolo del "Pudridero", como estado generalizado de la nación, es señalado por la autora como "mito fundador" del grupo, en la lógica de generaciones que, como ella misma reconoce, su texto analítico "visita" de nuevo pese a su "aura algo pasadista" (732).

${ }^{59}$ Gutiérrez Girardot, Ensayos 81 y Jiménez Panesso, Historia de la crítica 169. Esto, por no hablar de la "subgeneración de los Leopardos", asistentes a las tertulias de Los Nuevos que después "se encargaron de fomentar una restauración de la sociedad señorial bajo el signo de un utopismo al revés: el corporativismo fascista, que en su forma menos brutal saludaba y postulaba el advenimiento de "una nueva Edad Media" (Gutiérrez Girardot, Ensayos 81).

${ }^{60}$ Jorge Zalamea, citado en Estripeaut Bourjac 744. V. pág. 69, nota 39, del presente trabajo.
} 
"evanescencia". La actitud de vanguardia de Los Nuevos no implicó entonces, respecto a todos sus miembros, avances significativos en materia literaria, a excepción de dos o tres nombres principales que, a pesar de ello, se podrían contextualizar en un cierto ideario general de "renovación". Pero al final, el vanguardismo en De Greiff y en Vidales, tal como se ha reconocido, no puede justificarse del todo por su pertenencia a un grupo que sólo de modo excepcional -incluso "accidental", por el reducido número de verdaderos “innovadores"- creó expresiones literarias acordes con ese nombre. Su vanguardia, aislada respecto a los demás miembros del grupo, se prolonga por otros cauces que trascienden a éstos en estética y perduración. Los Nuevos, al no formar en conjunto una vanguardia radical propiamente dicha ante la tradición literaria e intelectual de su medio, responden más a la definición de "vanguardia ecléctica" del grupo argentino Martín Fierro, según Sarlo, caracterizada por su "moderatismo", por su "desatención de las vanguardias europeas más radicales" y por los mismos tonos literarios de las escuelas que denostaban ${ }^{61}$.

Pero la distinción entre De Greiff y sus compañeros no se limita en exclusiva a las prácticas de vanguardia que aquél ejerció en su material propiamente artístico, sino que se extiende también a un plano ideológico, al comparar el carácter de su vanguardia con la búsqueda

${ }^{61}$ (Sarlo 242, 243, 247). Sobre este tema, Jiménez Panesso, retomando otra tesis de la autora argentina, señala: "La revista de Los Nuevos no puede considerarse, propiamente, una revista de vanguardia, pero sí una revista modernizante, si nos atenemos a la clasificación propuesta por Beatriz Sarlo entre 'revistas de modernización' y 'revistas de ruptura'. Al presentarse como una revista generacional, privilegió, entre sus objetivos básicos, el de la crítica a la generación que los precedió, la del Centenario. Esa crítica los llevó a posiciones más o menos radicales, para contrastar con las actitudes y comportamientos políticos y estéticos excesivamente moderados que atribuían a sus antecesores" (Poesía y canon 89). No obstante, la clasificación del autor no resulta muy clara pese a su convicción, si se tiene en cuenta que, en Una modernidad periférica, Sarlo considera "modernizante" la revista Proa, y "de ruptura" la del grupo Martín Fierro, cuyas semejanzas con Los Nuevos aquí son evidentes, incluso en su carácter "ecléctico", "moderado" y falto de "radicalismo". En este punto, hay que tener cuidado con el empleo de las categorías. La revista de Los Nuevos es claramente una revista "de ruptura" con la tradición intelectual de su época, y la precisión u objeción que debe hacerse se refiere más bien a su producción literaria de conjunto, donde, como se ha dicho, no lograron consolidar, con todo, un frente sólido de vanguardia. Pero su significado ideológico de "ruptura" sigue intacto en la sociedad colombiana de principios del siglo XX. Por otro lado, es injusta la objeción de Rafael Gutiérrez Girardot al vanguardismo en Los Nuevos, al asegurar que "no lograron demoler esa sociedad" que combatían, "porque ella se encontraba ya en proceso de disolución" (Gutiérrez Girardot 81). En efecto, una objeción semejante podría hacerse no sólo a Los Nuevos en particular, sino a todos los movimientos más radicales de la vanguardia histórica en general, tanto en Latinoamérica como en Europa. Es una cuestión referida nada menos que al "fracaso" de las vanguardias, una controversia que aún hoy en día parece no resolverse. Objetar el vanguardismo de Los Nuevos por no lograr "demoler" la sociedad que combatían es rechazar la existencia de la vanguardia misma por no haber cumplido con el programa de "unión de arte y sociedad" que se planteó. La discusión aquí no debe centrarse en las consecuencias "directas" de estos movimientos en la sociedad, sino en la introducción en el arte de una protesta que, además de ser irrevocable en la reflexión estética, sentó las bases de una crítica a la tradición artística de la modernidad que después se profundizó de muchas maneras. 
proclamada por el grupo, incluso en su núcleo más radical. Para precisar estas diferencias, resulta interesante examinar la categoría de lo "nuevo" en la relación específica que Los Nuevos establecen respecto a la tradición literaria que les precede, o más exactamente en la que se enmarcan. Sobre la problematicidad que implica esta categoría en la historia del arte y la estética del siglo XX, entre todo lo escrito al respecto, se puede abordar, para efectos de este trabajo, el texto del profesor chileno Sergio Rojas acerca de la concepción de la historia que este tipo de denominaciones implican. Desde la formulación de la crítica de Ernst Gombrich al método historiográfico de Erwin Panofsky, el autor habla de esa suerte de imprecisión ideológica que supone el análisis tradicional de las obras de arte de vanguardia, por cuanto suponen una concepción lineal de la historia y el progreso que de ningún modo es problematizada. La vanguardia se reconoce como tal, en esa comprensión de sí misma como "clausura" de la tradición burguesa, según la caracteriza Peter Bürger, con base en un historicismo que presupone un avance unilateral e inmediato, sin ningún tipo de discontinuidad, con relación al pasado, es decir, con base en la figura dialéctica del devenir en Hegel:

[...] la dialéctica le da al devenir la dirección de su propio agotamiento, que corresponde al proceso de "realización" de las posibilidades contenidas en una época determinada. Esto significa que no sólo es histórica la realización concreta de las ideas dominantes en el "presente", sino también esas mismas ideas que han nacido como "posibilidades" pero cuyo contenido llega a develarse recién con su consumación. La tarea del presente es, pues, "llevar a cabo"; es decir, llevar a realidad concreta, conducirla hacia su fin en la plena autoconciencia. (Rojas 207-208)

La comprensión del presente como momento de "agotamiento", en aras de la "realización" de las posibilidades contenidas en una época determinada", es la adecuación involuntaria a la noción moderna del devenir de la historia en general y del arte en particular, formulada por Hegel. Es la concepción de la propia época como momento oportuno o casi "necesario" de la revaluación de los modos del arte anterior, donde los movimientos de avanzada, con inclinación mesiánica claramente enfatizada, serían los llamados a ejercer semejante tarea. Los Nuevos participan de esta percepción histórica:

El presente es el tiempo de Los Nuevos. Lo pueden controlar y les da la sensación de existir para sí mismos, de ser una conciencia y una entidad. La urgencia de presente que expresan corresponde a la 
inconsistencia de su pasado; Jorge Zalamea afirma: "es hoy y no ayer nuestro día". Del mismo modo, el instante es para ellos pulverización del tiempo fijado a la vez que unidad perfecta de adecuación a su momento. (Estripeaut Bourjac 747)

En este punto, la concepción hegeliana de la historia que predomina en una tradición pretendidamente objetada por la vanguardia, vuelve a imponerse de manera arbitraria y paradójica $^{62}$ :

Sin duda que ésta es la manera "filosófica" de considerar la historia, es decir, considerar que el devenir de los asuntos humanos tiene el sentido formal de la autoconciencia: un sujeto que se conoce o que se "relaciona" consigo mismo en la medida en que suprime la opaca trascendencia del mundo que lo separa de sí mismo. Dicho de otra manera, la autoconciencia en la historia se cumple al descubrirse el sujeto como "autor del mundo" en el que habita. (Rojas 208)

Los Nuevos, incluso en su núcleo más vanguardista, y por eso mismo, no escapan a las contradicciones de esos movimientos que hicieron explícitas sus intenciones respecto a su pretendida revaluación de la tradición de la modernidad, al incorporarse a esa "tradición de la ruptura" que, en palabras de Octavio Paz, es la misma "tradición de lo moderno" que "encierra una paradoja mayor que la que deja entrever la contradicción entre lo antiguo y lo nuevo, lo moderno y lo tradicional" (Paz 22):

[...] la tradición moderna: es una expresión de nuestra conciencia histórica. Por una parte, es una crítica del pasado, una crítica de la tradición; por la otra, es una tentativa, repetida una y otra vez a lo largo de los dos últimos siglos, por fundar una tradición en el único principio inmune a la crítica, ya que se confunde con ella misma: el cambio, la historia (27).

La proclama de la vanguardia como autoconciencia de la historia, que denuncia el agotamiento de la modernidad y se erige ella misma en heraldo de un nuevo amanecer, no puede escapar a la tradición de esa modernidad que cree negar y pretende clausurar en definitiva. Es por ello que no hay nada más tradicional en la modernidad que el nombre de lo "nuevo" como sustantivación de un proceso social o artístico en particular. Para una dialéctica en que "no sólo la historia puede ser comprendida en la autoconciencia, sino que

\footnotetext{
${ }^{62}$ Es la misma paradoja que advierte Sarlo al decir que "la consolidación y el prestigio de la tradición cultural crean, paradójicamente, la fuerza de su vanguardia” (Sarlo 212). V. pág. 138, nota 57, del presente trabajo.
} 
'consiste en el devenir de la autoconciencia misma"”, como lo formula Rojas acudiendo a Gombrich y la crítica del historicismo (Rojas 208), el relativismo de una conciencia que marcha siempre hacia adelante sin llegar jamás a su consumación, hace que el signo de ésta sean las formas agotadas y relegadas en todo momento al pasado:

El "relativismo" opera sobre el sentido historiográfico del arte contemporáneo, con lo cual se explicaría el hecho de que cada obra y estilo se inscribe en un devenir que inmediatamente lo excede; pero a la vez - y esto es fundamental- la misma historia del arte comprendida como un todo es relativa, y se inscribe en el proceso de la autoconciencia que la excede. Esto da lugar a la paradoja de que la autoconciencia en el arte implica la "conciencia del fin" del arte; es decir, el arte se conduce internamente hacia su agotamiento, porque en él la conciencia sabe del fín como esencia del relativismo y de la "historia" concebida desde éste. En principio, el puro relativismo sería el fin de la temporalidad como devenir, correspondería por lo tanto al tiempo en el que ya nada deviene pues nada "queda": tiempo de una especie de post historia. (Rojas 209)

En estas condiciones, la autoconciencia del arte como fin de su historia implica a un mismo tiempo una línea de progreso y la relatividad de todo progreso, pues no hay parámetros para medir éste, a no ser esa ruptura que, como hemos visto, está en el centro del concepto de la modernidad misma. Los Nuevos, "huérfanos de pasado y de historia" tras la "negación de su genealogía" (Estripeaut Bourjac 738), son tan huérfanos de pasado y de historia como toda una tradición de la modernidad, anterior a ellos, que pretende rechazar, por su propia naturaleza, cualquier forma del pasado. La crítica al círculo de la autoconciencia moderna, que sólo existe en la medida que se proclama momento del presente y por lo tanto caduca en cuanto forma gastada desde antes de nacer, no se realiza del todo aquí, sino más bien en la posibilidad de otro modo de enunciación frente a esa tradición moderna. El presente como tiempo por excelencia de Los Nuevos, lo que "pueden controlar y les da la sensación de existir para sí mismos, de ser una conciencia y una entidad”, no se basa tanto en la "inconsistencia de su pasado", según Estripeaut Bourjac, sino más exacta e inversamente en la consistencia de ese pasado, de donde se deriva la tradición de la ruptura de la que habla Paz. El círculo se debe romper o por lo menos problematizar, entonces, en una concepción de la subjetividad que se permita escapar a la tentación de la conciencia de sí misma, un descentramiento de esa univocidad que caracteriza la tradición moderna del dominio del sujeto frente al objeto o frente a la dialéctica que existe sólo en función de él, cuando de 
acuerdo a Rojas, "la autoconciencia en la historia se cumple al descubrirse el sujeto como 'autor del mundo' en el que habita". En De Greiff, el sujeto y el objeto experimentan un desplazamiento de sus cauces tradicionales en la enunciación. En ese procedimiento está la clave de su diferencia con el contenido de las proclamas de Los Nuevos, por lo cual, a diferencia de lo que parece pensar Estripeaut Bourjac, su vanguardia supera la vanguardia del grupo al que perteneció, y debe valorarse según sus propias características, más que de acuerdo a proclamas demasiado dependientes de un discurso de la modernidad que, como vanguardia que anunció una especie de posthistoria, Los Nuevos también compartieron.

Más allá de los límites de las paradojas de la vanguardia, De Greiff desarrolló en toda su obra -en la que su participación en Los Nuevos es sólo una breve etapa- una estética de avanzada que no por integrar una heterogeneidad de elementos antiguos y modernos, incluso asociados al modernismo, dejaron de significar una crítica y un distanciamiento sin precedentes de la institución literaria de la primera mitad del siglo XX. La ironía contra la poesía y contra sí mismo como poeta, un conflicto de planos de enunciación relacionado con la divagación discursiva sin rumbo fijo y con la fragmentación del sujeto en múltiples identidades -materializadas en heterónimos, sujetos colectivos a partir de la unión de éstos y trozos de subjetividad momentánea que no llegan a formar identidades precisas-, es el principio de una labor deconstructiva que rechaza la estabilidad y la univocidad del sujeto en la tradición de la modernidad. El deslizamiento por fuera de las seguridades de la enunciación características de la modernidad, como la pretensión de una conciencia sobre el valor o el significado histórico del propio decir, lo mantiene alejado del círculo moderno que regresa siempre sobre sí mismo, basado en la idea de subjetividad cerrada que, al participar de la tradición de la ruptura y sin puntos de fuga establecidos, se consume a ella misma. La poesía en De Greiff es la apertura de un sujeto que abandona la autoconciencia de su devenir histórico para desintegrarse en la discontinuidad de la escritura, esa escritura que es entendida por Juan Manuel Cuartas, en el sentido derridiano, como "espacio abierto, fluyente, diseminante" (Cuartas 117). Es la escritura que desdibuja los límites del sujeto y su experiencia de la exterioridad a él, no en una autoconciencia del sujeto como "autor del mundo" en que habita, sino por el contrario, en la expresión de una palabra que fusiona las 
identidades, una definición indefinida de sí mismo respecto a lo demás, que por ello sigue siendo él mismo y a su vez todo lo demás. Volvamos a este poema:

\author{
Ninguno yo conozco. \\ Ninguno. \\ Y el multánime y el multiforme Yo, lo han sido todos ellos. Y otros más que olvidé. \\ El multiforme Yo, lo han sido todos ellos: el multánime, dentro mi pequeña anímula; y el multiforme, \\ en la mi diminuta proteidad. \\ Ninguno yo conozco. \\ Ninguno ya conozco...
}

Y otro soy Yo: que se fugaron. (De Greiff 281)

El Yo discontinuo no es el mismo Yo "organicista” (para emplear la definición de Bürger sobre el modo de enunciación del sujeto en la obra de arte organicista) elaborado desde las bases epistemológicas de la tradición de la modernidad. Es un Yo que no es un Yo, que es otros Yo y que es el único Yo posible, todo ello a un mismo tiempo. Lo extensivo de la fragmentación en lo reducido de la "diminuta proteidad" es la condensación de la contradicción en formas enrevesadas del todo contemporáneas, que distorsionan la tradición lineal del sujeto y sus vías de desarrollo, siempre unívocas y hacia adelante. Aquí no existe ningún "atrás" o "adelante", pues el primero podría perfectamente ser el segundo y viceversa, del mismo modo que el "antes" y el después" son sólo momentos provisionales en la constitución de un Yo discontinuo. En un espacio de subjetividad abierto en el tiempo y el espacio, que trastoca sin cesar lo individual con lo multitudinario, las formas de constitución del Yo no responden a modos tradicionales u "organicistas" de enunciación. El sujeto es provisional y momentáneo, una entidad "suplementaria" al modo de Derrida, como el poeta corrobora en la dedicatoria del ejemplar de uno de sus "mamotretos": "Al poeta don Álvaro Mutis, en nombre de Le Gris, Aldecoa y Gaspar (ya difuntos), dedica con asaz simpatías cordiales y espirituales -como es obvio- su de ellos tres usufructuario" (Mutis 2). Esta concepción del sujeto y su división corresponde del todo a la que se percibe a lo largo de toda la obra del poeta. De hecho, el título de "usufructuario" es clave en la interpretación de otra de muchas relaciones establecidas entre las distintas subjetividades, 
esta vez como "uso", "transferencia” o "intermediación”. El acoplamiento de subjetividades no conoce fronteras en este fluir de la escritura que ha desbordado los cauces tradicionales de la enunciación. De nuevo, la heteronimia al modo de Pessoa es insuficiente para caracterizar las múltiples conexiones entre avatares del Yo que aquí surgen, se presentan y desaparecen a ritmos escriturales vertiginosos. El logos adquiere así otra función en relación con la constitución de la subjetividad por medio de la palabra. Muy lejos de dar al sujeto el dominio de la naturaleza por el concepto, el lenguaje arrasa con toda identidad unívoca de éste y del universo, y se convierte en una entidad autónoma que fluye sin cesar, de modo informe y discontinuo. Ciertamente, es un lenguaje más acorde con conceptos contemporáneos como “diferimiento", "suplementariedad”, “juegos de lenguaje” o "muerte del autor": un lenguaje que, como pocos y de manera tan singular, profundiza en la remisión ininterrumpida entre significaciones, el carácter transferible o intercambiable de mil nombres y adjetivaciones, la suspensión de sentidos determinados de palabras heterogéneas en contextos diferentes, o la disolución de la seguridad de la univocidad creadora en un lenguaje vertiginoso en que se fusiona lo uno y lo "otro",63.

La base del distanciamiento de esta poesía respecto a la tradición de la modernidad y de la literatura colombiana de inicios del siglo XX, el factor decisivo que le otorga su carácter de vanguardia, está entonces en esa concepción descentrada del sujeto que tiene implicaciones en todos los ámbitos. En efecto, al cuestionar y desestabilizar la posición del sujeto de la enunciación, se cuestiona y desestabiliza nada menos que todo lo que se referencia a través

\footnotetext{
${ }^{63}$ Los conceptos de Jaques Derrida, Ludwig Wittgenstein y Roland Barthes se toman aquí, exclusivamente, como referentes teóricos para un posible estudio sobre De Greiff en el contexto de los diferentes inicios o los numerosos desarrollos de la literatura contemporánea en Colombia y Latinoamérica, sin asegurar por ello, de ninguna manera, que toda su estética sea susceptible de ser enmarcada en esos parámetros. De nuevo, es preciso contemplar esta obra en toda su heterogeneidad, y por eso mismo, no negar el importante componente de avanzada que comporta y que aquí se está examinando. La discontinuidad y la convergencia de numerosas estéticas que esta obra plantea demandan interpretaciones hasta ahora no tradicionales que la ubiquen, como corresponde, en el siglo XX y sus múltiples disociaciones de la cultura y el pensamiento heredados del siglo anterior. En la necesidad de abordar nuevos y más contemporáneos marcos teóricos para interpretar una obra que plantea problemas de significación y subjetividad tan vigentes en la actualidad, sería preciso examinar, por ejemplo, cómo participa De Greiff en esa noción de literatura de Derrida, citada por Christoph Menke, que pone en diálogo las concepciones arriba mencionadas y otras también contemporáneas, desde la escritura misma del poeta como entidad que constituye el único sujeto posible -"uno y múltiple", según Cobo Borda-, con centros de enunciación transferibles o intercambiables, y toda la fuerza para desdibujar los límites de la identidad y la realidad exterior: "La literatura indica así, prácticamente, el más allá de todo: la operación, la inscripción que transforma el todo en partes que piden ser completadas o suplidas. Tal suplementariedad abre el juego literario en el que desaparece, con la literatura, la figura del autor" (Menke 194; las cursivas son del texto).
} 
de esa enunciación que el sujeto configura y que a su vez lo configura. Se desvirtúa así la diferenciación o identificación introducida por el lenguaje en una realidad heterogénea, y por tanto las relaciones entre las respectivas diferencias o identidades, que ante todo son diferencias y relaciones procedentes de los niveles semánticos y sintácticos. En esta concepción ya contemporánea del lenguaje y la escritura, en esta semántica intercambiable y sintaxis de relaciones significantes mutables, se integran esas diferencias o identidades, en exclusiva y como se ha explicado, a modo de estados momentáneos de la enunciación, que como las subjetividades múltiples, dispersas y de nuevo integradas, no perduran en una vertiginosa corriente de significaciones que todo lo arrastra. La enunciación, como parte del proceso histórico en la constitución del sujeto, entra en una nueva fase que la separa del principio de coacción ligado al dominio de la naturaleza en la concepción ilustrada de la modernidad, donde las exigencias del concepto como instancia de representación, y por tanto de equivalencia, son claras:

Mediante el pensamiento los hombres se distancian de la naturaleza para ponerla frente a sí de tal modo que pueda ser dominada. Como la cosa o el instrumento material, que se mantiene idéntico en diversas situaciones y así separa el mundo -como lo caótico, multiforme y disparatado- de lo conocido, uno e idéntico, el concepto es el instrumento ideal que se ajusta a cada cosa en el lugar donde se las puede aferrar. Por lo demás, el pensamiento se vuelve ilusorio siempre que quiere renegar de la función separadora, de la distanciación y objetivación. (Horkheimer y Adorno 92)

El principio de la equivalencia como factor dominante en la sociedad burguesa, que según Max Horkheimer y Theodor Adorno "hace comparable lo heterogéneo reduciéndolo a grandezas abstractas" (63), encuentra aquí una formulación caricaturesca, pues al integrarse todo -subjetividades, adjetivaciones, calificativos, flora y fauna de la geografía del poeta (pingüinos, búhos, sapos, charcas), personajes secundarios (fuentes constitutivas del Yo en eso que Holguín llama “instrumento desconcertante de su autobiografía”), arcaísmos y neologismos, referencias estéticas e históricas, minucias concretas o grandezas abstractas, en suma, identidades o diferencias semánticas y sintácticas- en una corriente de la escritura "abierta, fluyente, diseminante" que todo lo arrasa y lo entremezcla, la equivalencia entre absolutamente todo rechaza la identificación de una sola relación entre el sujeto y un objeto concreto a través de la fijación de un respectivo concepto. De tal forma, la equivalencia 
indiscriminada y por tanto relativizada revierte el proceso de la equivalencia sistemática y diferenciada de la modernidad, por la cual "las múltiples afinidades entre lo existente son reprimidas por la relación única entre el sujeto que confiere sentido y el objeto privado de éste, entre el significado racional y el portador accidental del mismo" (66). La disolución de la equivalencia diferenciada en formaciones desfiguradas y movedizas que restablecen "las múltiples afinidades entre lo existente", es regla en esta escritura que rechaza por principio la solidez de la identificación. Es una escritura que se autodefine en "De Babia", larga y accidentada serie de múltiples y cambiantes identificaciones de "Farandúlicos sujetos de avería”, en la cual "Continúase -todavía otra vez más- con la Secuencia, aún sin mayor ni menor consecuencia ni máxima ni mínima trascendencia doctrinal aparente, con la Secuencia de las Aventuras y Malaventuras de los tronados Farandúlicos trotamundanos", (De Greiff, Obras 588-589):

Nada de tales cosas. Son meros giros en descubierto: Que todo se va convirtiendo en lugar común y en frases construidas - prefabricadas en serie- y así suele decirse sin compromisos ni responsabilidad de persona.

Parlando de otra guisa, oh Polemarco de mí: duro, perduro, vegeto -revejete-, vivo, supervivo, como si ello no tuviese relación muy íntima conmigo o que conmigo no tocase o que importárame un ardite de bledo. Así es. Cuando no nada ya se ambiciona, cuando aún nada se ambiciona. Alguna vez ambicioné? ni nadería... Cuando se espera ni nonada -que se es escéptico y, sobre escéptico, tomado del hastío, que es moho-. Si se esperó alguna vez? Ni nonada... Se dura o se vegeta o se infravive sobrado, con señera displicencia señorial, cada hora más densa. Y si se piensa, se cogita, función es ya también peor que vegetativa, sin poner sesos en ello o sin tenerlos -en sesera- para ponerlos: cogitación, meditación mecánica si subconsciente. Y si se escribe -manía ya enquistada, después de terca-, sin objeto es, sin sujeto es, sin base, fundamentación ni sustentación. Sin tón ni són y puro són y són, sin razón ni sinrazón: mera orgánica función. Se escribe así sin escribir por escribir, como en ocasiones se lee por leer sin leer (divagando entre líneas), sin atender a lo ni entender eso que de esa manera se sobrelée: gratuita escribanía. Sólo acción caligráfica. Aunque es casi siempre tan teratológica la letra como anodina la canción ${ }^{64}$.

\footnotetext{
${ }^{64}$ De Greiff, Obras 603-604. El carácter discontinuo de este lenguaje, enteramente accidentado, profundiza en la ironía de denominaciones, como "catálogo de inepcias", "maremágnum de majaderías" (157), "farsas de un barroco gusto, o mal gusto" (61), "lógica de ácrata anacoreta" (9), "tergiversaciones y facecias feriales" (285), etc., que el poeta otorga a su escritura en algunos "mamotretos" más tempranos, potentes en sí mismas para criticar la seguridad de una tradición discursiva fundada en la seguridad del logos, como ya se ha visto, pero aún no exploradoras, a este extremo, de las ideas que así se formulan. Esta clase de apartados ya más tardíos,
} 
Esta fracción de la secuencia proporciona importantes claves para comprender la operación de designificación o desidentificación de esta escritura. Desde una ironía que, en su calidad de "valor coextensivo del Yo ante la representación" (Cuartas, León de Greiff 119), opera la descomposición del Yo en la obra, siendo de tal forma "su discontinuidad y su escritura al mismo tiempo" (114), los "tronados Farandúlicos trotamundanos" son presentados por un sujeto indeterminado que presenta a su vez esa multitudinaria, accidentada y discontinua secuencia de "giros descubiertos", "lugares comunes" y "frases prefabricadas en serie", donde la escritura es "mera orgánica función", "sin tón ni són y puro són y són, sin razón ni sinrazón". El sujeto está destruido en una poesía con un lenguaje destruido, y por tanto así lo está esa realidad incierta que se enuncia a través del concepto: se escribe "sin objeto" y "sin sujeto"; para más señas, "sin base, fundamentación ni sustentación". Una escritura sin sujeto y sin objeto no puede reclamar base alguna, sino sólo la ruptura de esa base que le da fundamento y sustentación a la tradición moderna del sujeto, enunciador de equivalencias diferenciadas en un mundo heterogéneo en que las "múltiples afinidades entre lo existente" restablecen así su vigencia. Pero esta inversión no se da al modo de las correspondencias simbolistas, restauradoras de un sentido profundo y secularmente metafísico para una realidad que ha perdido esas bases o "seguridades" que "la mente creía guardar a propósito de sí misma" (Lyotard 19-20), sino al modo de una desarticulación general de significados y su posterior mescolanza en el fluir de una escritura diseminante, en que los elementos de la realidad entrechocan, se disuelven y eventualmente se funden en entidades o identidades indeterminadas. La "acción caligráfica" de la letra "teratológica" es la consigna que guía las técnicas más avanzadas de la escritura -en poemas a lo largo de la obra completa y sobre todo en los "mamotretos" en prosa-, pues la teratología es el criterio fundamental de la creación, el paradigma del Yo desarticulado que rechaza el modelo sintagmático u "organicista" de relaciones entre significados, "no ya sujeto a la búsqueda de conexiones

en cambio, lleva a término la expresión de una subjetividad que se construye a sí misma como desubjetivada sólo en el espacio de la escritura en que se configura su posición o des-posicionamiento. A esto apunta el "oxímoron" que Sergio Rojas recomienda tener en cuenta en el análisis del arte moderno y contemporáneo, donde "no se trata simplemente de renunciar a la individualidad del artista, sino de recuperar la figura de la subjetividad individual en una época que ha llegado a descubrir y a valorar la experiencia como una instancia de radical 'conmoción' de la subjetividad individual. En la dirección de esta hipótesis, la obra de arte puede ser considerada como un trabajo de producción de esa 'subjetividad alterada', la puesta en obra del oxímoron de una subjetividad que es contemporánea de su experiencia del mundo" (Rojas 211). 
lógicas, sino aplicado al procedimiento constitutivo del texto" (Bürger 144). La teratología, como logos sobre las anomalías y malformaciones de organismos, aquí aplicada al procedimiento de enunciación en que sujeto y objeto se desfiguran mutuamente en vez de conformarse y diferenciarse, constituye ciertamente el rechazo de la idea moderna de una subjetividad por completo libre de accidentes corporales del mundo de la materia, lejana de esa "inmersión en el ser inmediatamente natural" no compatible con la autoconservación en que se configura el "sí mismo", y que así se sublima a la pureza de una entidad abstracta: "El sí mismo, que tras la metódica eliminación de todo signo natural como mitológico no debía ya ser cuerpo ni sangre, ni alma ni siquiera yo natural, constituyó, sublimado en sujeto transcendental o lógico, el punto de referencia de la razón, de la instancia legisladora del obrar" (Horkheimer y Adorno 82-83). El sí mismo como punto de referencia de la razón y de la escritura en la tradición de la modernidad -que consolida la división del ser entre "el logos, que con el progreso de la filosofía se reduce a la mónada, al mero punto de referencia", y "la masa de todas las cosas y criaturas exteriores" (64)-, se ve confrontado cuando la escritura, que configura ese sujeto como punto de referencia de la razón, se desborda en discontinuidad y consuma su desintegración. La idea de la "negación determinada" de los contrarios en vías de su síntesis ulterior, que en la dialéctica hegeliana implica "la autosatisfacción del saber todo por anticipado y la transfiguración de la negatividad en redención" (77), se hace "negación indeterminada" en una escritura que problematiza el presupuesto básico de la separación, ya asumida por costumbre, entre sujeto y objeto. Con la teratología del logos de la razón, el lenguaje -que no puede hablar sino a partir sí mismo - formula su confianza "en la vida directamente" y se aproxima a la "prehistoria", al "impulso mítico" contrario al "sí mismo" de la modernidad, movimiento tan "absurdo como la embriaguez", en la medida que el progreso "ha cubierto de maldición al olvido de sí tanto en el pensamiento como en el placer” (83). Es en esta confrontación del "sí mismo" de la modernidad donde el lenguaje en De Greiff expresa ese "estado de alma dionisíaco": no sólo por la "exuberancia vital en las formas de expresión, en el cúmulo y la variedad de las imágenes, en el vigor representativo de las comparaciones" (Sanín Cano 261), ni por ese "delirio" del acto de nombrar e intentar "abarcar el universo con la palabra" (Cuartas 120-121), sino más exactamente por la negación de una subjetividad construida en el principio de autoconservación, que sucumbe al final en la lúdica creativa y paradigmática 
de una escritura teratológica. Nada más que "verborragia", llamaría a esto De Greiff en su típico procedimiento de descomposición del Yo: "Sobre mi verborragia oceánica navego / como un víking que fui: yo me soy nave, / mar y piloto y galeote -cuatro en uno-" (De Greiff, Obras 522). El "sí mismo" está del todo desintegrado: es primera persona amplia y por ello indefinida, transferencia de identidad a antepasados nórdicos, complementariedad cuádruple de trozos del sujeto y de la realidad presuntamente "exterior", todo navegando naufragando, si se quiere- en la "verborragia oceánica" con que se define al sujeto mismo, nada menos que su propio ser conformado por - desde, en, con, a través de- una abundancia no controlada, abrumadora y designificante de la escritura.

En la dialéctica de modernismo y vanguardismo que presenta esta escritura, factores como la individualidad o la diferenciación de ámbitos artísticos y no artísticos demandan una problematización. No es ésta una obra que asimile por completo concepciones del lenguaje predominantes hasta el siglo XIX y que sustentan la tradición literaria de la modernidad hasta aquella época. Si las manifestaciones más tardías del simbolismo y el modernismo, como Hugo von Hofmannsthal en Europa o José Asunción Silva en Hispanoamérica, habían problematizado los alcances del lenguaje respecto a la realidad de la que forma parte mediante un empleo todavía tradicional de ese mismo lenguaje, en De Greiff encontramos multitud de versos, poemas y "mamotretos" enteros que rechazan la lógica decimonónica y formulan un criterio del todo opuesto, como se ha corroborado hasta ahora. Una escritura que no se ciñe a los modelos literarios institucionalizados para atacar esa institucionalidad, es una escritura que toma distancia de esa tradición que Bürger identifica con el desarrollo del arte desde el Renacimiento hasta los tiempos del arte por el arte. En el De Greiff vanguardista, como en los demás vanguardistas, el lenguaje es ante todo una práctica que trabaja en la literatura, pero a partir de allí establece una crítica a las bases fundamentales que ese lenguaje, desde luego no exclusivo de ella, ha tenido hasta ahora. No hay "arte por el arte", como se ha pretendido algunas veces, en una poesía que rechaza y hasta ridiculiza esa sacralidad secular que aquel movimiento proclamó, y menos al socavarse las bases fundamentales de la individualidad consistente y segura de sí misma, premisa obligada de esa proclama de autosuficiencia. La poesía en De Greiff, desde el ámbito específico de la literatura, no es sólo una crítica a la institución literaria y por tanto artística de su contexto, 
sino también a la condición subjetiva que alimenta toda esa institución, extensible aquí a todo el pensamiento y la tradición de la modernidad. Si en el caso del surrealismo hay una inmersión en el subconsciente con miras a la liberación del individuo de las coacciones sociales que no le permiten ser en toda su plenitud, y en el cubismo hay una multiplicidad de perspectivas para una realidad que se presenta a nosotros fragmentada y en niveles superpuestos, en De Greiff hay una crítica a la noción indivisible del sujeto y su percepción estable de la realidad a través de la desarticulación de las partes constitutivas de la enunciación. La crítica, ciertamente, se extiende y alcanza implicaciones más allá de los límites literarios y artísticos. La autonomía se mantiene, pues la escritura no desarrolla sus problemáticas en ámbitos distintos a la propia forma literaria, ni pretende restaurar para el arte la articulación de intenciones extraliterarias diversas y explícitas que de algún modo se lograron depurar en el siglo XIX. Pero tampoco se declara la autosuficiencia de la práctica artística al modo modernista, con nociones elevadas y grandilocuentes que le restituyen la sacralidad cuestionada en todos los ámbitos por la sociedad burguesa. La dialéctica de modernismo y vanguardismo nos presenta aquí un nuevo horizonte del individuo y de los alcances de la obra de arte en ámbitos diferentes al de su producción. Una obra que no sólo reclama un espacio del todo autónomo, como lo había reivindicado el arte por el arte, sino que plantea problemáticas del sujeto y el lenguaje ya por completo lejanas de la literatura de esa corriente, trasciende el ámbito de la mera autonomía y se inscribe en una postura de crítica al discurso moderno, el cual ha nutrido, con su estructura invariable, tanto el mismo arte por el arte como en general el logos de los demás discursos de la modernidad. Por ello, De Greiff escapa a la contradicción involuntaria de un arte finisecular que pretende estar separado de la sociedad, al hacer de la contradicción entre autonomía y dependencia, explícitamente, su espacio predilecto: manifestando que la poesía tradicional no realiza sino una "pura negación subjetivista" y que "depende todavía demasiado del medio que pretende rechazar" (Gómez 166), De Greiff asume el rechazo de la tradición, prolongada tanto en la poesía como en otros discursos, en el nivel de un lenguaje y una escritura que desintegra las identidades, que desdibuja los límites del sujeto y el objeto. La tradición discursiva de la modernidad es así confrontada por eso que Christoph Menke, al hablar de la "singularidad estructural" de la obra de arte autónoma que "se da a sí misma sus propias reglas", describe como "trabajo de descomposición, al que la experiencia estética somete el funcionamiento 
de los otros modos de discurso" (Menke 19). La dialéctica de modernismo y vanguardismo en De Greiff, que es dialéctica de la proclama de autosuficiencia radical y por ello marginal en posturas finiseculares como el esteticismo, y la proclama del arte como transgresión de otros discursos de la sociedad en la vanguardia histórica, es entonces una dialéctica de la autonomía y la soberanía del arte, fundamental en la teoría de la negatividad estética de Adorno, y en la que Menke identifica lo que para él debe ser factor central en la reflexión estética actual ${ }^{65}$.

Adorno formula su teoría de la negatividad de la experiencia estética en relación con dos términos en apariencia excluyentes entre sí, que no obstante deben confluir si se quiere construir una instancia de crítica a la razón en el ámbito específico del arte: la "soberanía", modelo de crítica a la razón, sólo sería posible dentro de la forma artística autorregulada, es decir, en el espacio de la "autonomía". Por tanto, el arte sólo podría ir más allá de sí mismo siempre que opte por no salir de sí mismo. La antinomia que esto comporta, según Menke, encuentra su solución en el plano semiológico aportado por la teoría deconstructiva, que al objetar los términos en que se plantea la teoría de la negatividad de Adorno, la depura hasta cierto punto de sus aporías y la complementa:

No carece de plausibilidad la objeción de Derrida cuando protesta por la asignación de la negatividad estética a la realización actual de su experiencia. Es una objeción que saca su fuerza de la tensión que amenaza desgarrar desde dentro la estética de la negatividad. Por una parte, la experiencia estética es

\footnotetext{
${ }^{65}$ Desde una perspectiva actual, según Christoph Menke, se ha planteado la inexistencia de la "antinomia" de la experiencia de la negatividad estética de la que habla Adorno, por la cual el arte es concebido "como un discurso autónomo entre otros $\mathrm{y}$, al mismo tiempo, como subversión soberana de la razón de todos los discursos", es decir, una tesis según la cual "es precisamente la apariencia (autonomía) del arte la que constituye su verdad (soberanía)", siendo así que no sólo "autonomía y soberanía no se excluyen mutuamente", sino que la soberanía presupone, en todos los casos, la autonomía (Menke 16-17). Para el autor, esta antinomia, no resuelta por Adorno, no debe ser simplemente ignorada en el análisis estético, imponiendo un término sobre el otro (autonomía no soberana corroborada por el "fracaso" de la vanguardia o soberanía no autónoma en la crítica del arte posmoderno), sino resuelta en el plano semiológico de manera que el concepto de autonomía "dé cuenta plenamente de su independencia frente a las otras reglas del discurso, y que sea igualmente compatible con el concepto de soberanía. Es necesario, al mismo tiempo, explicar esta noción de manera que se afirme su potencial crítico frente al predominio de la razón, sin que signifique menoscabo heteronómico del principio de autonomía" (16). La teoría de Menke es muy adecuada en la aproximación a una obra que, al establecer la dialéctica de modernismo y vanguardismo de la forma que se ha indicado, responde explícitamente a una exigencia de autonomía, a la vez que comporta la transgresión de las reglas del discurso en que se fundan los demás ámbitos de la modernidad: su crítica a la razón moderna se adecúa al modelo de la soberanía autónoma, pues participa de elementos esteticistas y vanguardistas antonomásticos de cada uno de los dos términos de la antinomia, y por ello es más que oportuno su estudio en la dialéctica de autonomía y soberanía que el autor formula.
} 
una negación procesual de toda comprensión automática que se abre a nosotros en el objeto estético como constitución de sentido. Pero, por otra parte, el alcance y la validez de esta negación se limitan al cumplimiento de la experiencia estética. (Menke 190-191)

Esta idea "a la vez total y limitada de la negatividad" que "cuestiona el funcionamiento de todos los discursos, y que, sin embargo, puede considerarse como un discurso especial entre otros" (191), conduce a "la marginación de la experiencia estética, especialmente después de haber sido reconocido su carácter negativo", una "complicidad de la estética tradicional con la metafísica, es decir, en el lenguaje derrideano, con la reconstrucción de nuestros discursos con vistas a su funcionamiento eficaz" (192). Esta complicidad con la metafísica implica una adecuación del discurso estético a su "eficacia", algo que Derrida, en palabras de Menke, cuestiona:

Por eso entiende Derrida el "reconocimiento" del arte en la estética como su "sometimiento" a una forma de discurso entre otros, en el que pierde su concepción subversiva. Con una expresión de Bataille, Derrida llama "sometida" o "servil" a la concepción del arte que lo rebaja a una forma limitada de discurso, frente a su contenido "soberano". El arte es, por el contrario, "soberano" porque sobrepasa los "deseos del sentido" que determinan los discursos no estéticos. Considerar el arte en su soberanía, significa no eludir ni rechazar "el peligro de no tener sentido", sino asumirlo y preservarlo. Es servil el rechazo de tal riesgo, y soberano su asunción. (192)

La consideración de la soberanía en el plano semiológico del sentido, o del no sentido, más allá de las precisiones teóricas que el autor busca introducir en el ejercicio analítico del arte, nos ofrece aquí, de paso, una interesante perspectiva de estudio de la escritura en De Greiff -complemento del enfoque hasta aquí desarrollado sobre el tratamiento de la subjetividad-, cuyas significaciones son trastrocadas en miles de convergencias con otras significaciones, suspendiéndose y reconfigurándose por tanto los sentidos que otorga la palabra, unidad de tensión de la significación-designificación. La discontinuidad, que rechaza por completo la comprensión automática en la procesualidad del discurso estético, puede integrarse también al rechazo de los "deseos del sentido" de los discursos no estéticos, al ser descrita sólo al mismo tiempo que se conforma, es decir, al asumir y preservar "el peligro de no tener sentido", siendo discontinua sólo desde la conformación de sí misma en discontinuidad: 
Y esto no es sibilino ni maledictino leonesco, seor Altazor, sino apenas baturrillero, magüer no bátese asnillo algún ni con la baticola, ni se le batanea, ni se le bate el batintín. Es un mero bateo del batólogo emérito cultor del fárrago, que no es la misma farra... Fárrago! Fárrago! Fárrago! caigo en la cuenta ahora apenas -musita Polimarco o Palinuro- de que los próximos libros del clan, los próximos siete, llamaránse todos Fárragos, y se diferenciarán entre sí -es un decir: vaya alguien a diferenciarlos-, por el secundario respectivo estrambote de cada unidad de la septina: los ya cuasi inmediatos Fárragos sexto y séptimo mamotretos del catálogo general, serán Velero Paradójico y Bárbara Charanga. Y etcétera y etcétera... Y ahora, allí, en el otro Fárrago múltiple, se asilará mi poesía -nova et vétera- no inclusa en mamotretos anteriores y la inclusa. Ni una ni otra inclusera... Fárrago! Fárrago! Fárrago! $(539-540)$

Negaciones ironizadas, nombres arquetípicos de la vanguardia latinoamericana, formas arcaicas y neologismos, incisos enrevesados, identidades múltiples, referencias a la propia obra pasada y futura, parónimos con significados suspendidos y modificados, "y etcétera y etcétera", todo es amontonado en desorden y lanzado al hervidero de la "verborragia oceánica" que conforma al Yo en la escritura, al "fárrago" del Yo. De tal forma, el "exilado príncipe de Nolandia" hace de esta tierra del No, de la negación del sentido, el reino de su autonomía; pero a su vez, como "capitán de los mis desatinos" (512), pone en práctica, en la escritura, el "trabajo de descomposición, al que la experiencia estética somete el funcionamiento de los otros modos de discurso" (Menke 19). El resultado lo describe el mismo De Greiff:

Imagináos el más tergiversado de los Caos posibles, de los de los Bogislaos y de los Beremundos, de los Segismundos de Marras y de los Agesilaos de Entrambosmundos. Y no es el más grande de los caos, el caos continente aparente, sino el allí contenido caos, psíquico, metafísico y metapsíquico y sensorio. El Caos Pancaótico que intégralo... Ah! buen caos! optimísimo caos! (De Greiff, Obras 540)

La escritura que pone en práctica el no-sentido implícito en esta suerte de manifiesto (como en otros textos que funcionan de la misma forma), es una escritura que no se aviene simplemente a considerarse una "anomalía" - de acuerdo a la terminología asociada con la "teratología" - perfectamente limitable en exclusiva al discurso estético diferenciado y no trascendente hacia otros modos de discurso, pues su crítica no sólo tiene vigencia en ese ámbito estético ni es del todo comprensible sólo a partir de él. Su crítica al sujeto de la 
"interioridad" y al objeto de la "exterioridad", mediante una enunciación que transgrede las diferenciaciones establecidas por la razón en este punto, debe considerarse, para ser potenciada en todas sus implicaciones, en su tensión con procesos de configuración de sentido consolidados por la razón moderna. De tal forma, esta poesía, al defender su autonomía y no hacer concesiones a intenciones o regulaciones de otros ámbitos, desarrolla al mismo tiempo el ejercicio de su soberanía respecto a la configuración de sentido en el marco de la razón moderna. Esta doble condición está dada por su integración negativa, al discurso estético, del proceso de configuración de sentido en discursos no estéticos. Por esto, la idea de "lectura textual" de Derrida -que implica la transformación de todos los discursos, estéticos y no estéticos, en textos, y de éstos a su vez en partes constitutivas o “"géneros" de un texto general", lo que hace que la "diferencia "estructural” de discursos se convierta en diferencias relativas entre esos "géneros" ya integrados ${ }^{66}-$, ofrece los medios de análisis adecuados para evidenciar en De Greiff la negatividad de la experiencia estética respecto al discurso estético y al sistema de significación de otros modos de discurso. De esa manera, esta poesía hace suya la caracterización de Menke:

"El hecho estético es soberano en la medida en la que no se inscribe simplemente en el tejido diferenciado de la razón plural, sino que lo transgrede. Si el modelo de la autonomía describe la validez relativa de la experiencia estética, el modelo de la soberanía le atribuye una validez absoluta, por cuanto que rompe simultáneamente el buen funcionamiento de los otros modos de discurso. El

\footnotetext{
${ }^{66}$ Menke 194. De aquí se deriva, según el autor, la diferencia entre la negatividad estética de Adorno y su complementación por parte de la teoría deconstructiva, diferencia referida en particular a sus alcances puramente estéticos en el primer caso y su trascendencia hacia otros modos de discurso en el segundo: “Ambas teorías lo explican [el proceso de la experiencia estética] como la realización de la negación en la que las tentativas de la comprensión se anulan a sí mismas, reduciendo cada significación estética construida, al nivel de simple material de selecciones significantes. [...] Pero estética de la negatividad y deconstrucción se oponen, sin embargo, estrictamente, en cuanto a la determinación de la validez de la experiencia estética de la negatividad. La estética de la negatividad limita la validez de la experiencia estética a su cumplimiento actual, cuando consideramos los objetos desde la perspectiva de su valor específicamente estético, de su belleza. El proceso de subversión de los esquemas no estéticos de comprensión sólo puede realizarse de modo necesario en ese discurso, distinto de todos los demás. En cambio la idea de lectura textual de Derrida amplía la validez de la subversión (estética) de la comprensión automática a los discursos no estéticos" (Menke 194-195). En efecto, "Derrida llama a este tipo de lectura del hecho estético, 'textual', pues transforma los signos estéticos en textos. Aunque sólo puede hacerlo transformado los discursos no estéticos en textos. Pero, al mismo tiempo, leer el signo estético como texto significa para Derrida hacer valer su negación procesual frente a los discursos no estéticos, de manera que queda socavado su funcionamiento correcto y se convierte en texto. La lectura textual no puede nunca limitarse a un solo tipo de discurso; leer un discurso como texto significa considerar todos los discursos como textos. En el proceso de lectura textual que accede a la soberanía superando lo estético, los discursos estéticos y no estéticos se convierten en 'géneros' de un texto general. Se reduce la diferencia estructural entre tipos de discurso a la diferencia relativa entre 'géneros literarios' de un único texto general" (194; las cursivas son del texto).
} 
modelo de la soberanía ve en la experiencia estética el medio de arruinar el predominio de la razón extraestética, construyendo así la instancia de una crítica en el acto de la razón”. (Menke 14)

La negatividad como instancia de crítica a la razón, aquí principalmente desarrollada en la descomposición del Yo en la escritura a través de lo que Cuartas llama su "coextensividad", es sin embargo la base de un distanciamiento en el cual debe definirse, en concreto, qué es aquello de lo que se toma distancia y cuál es el horizonte hacia donde se verifica esta nueva dirección. La referencia al cuestionamiento de la modernidad implica necesariamente una perspectiva de aquello que la trasciende, en particular, de las manifestaciones del arte y el pensamiento agrupadas bajo ese concepto "opalescente" de la posmodernidad, según lo caracteriza Albrecht Wellmer. Pero la cuestión así mencionada no se refiere en exclusiva, ni mucho menos, a la poética más avanzada del descentramiento en De Greiff, sino en general a todas las tendencias que, de una u otra manera, han formulado sus propias críticas a rasgos fundamentales de la tradición moderna, lo cual les ha valido, de manera amplia y a veces no muy precisa, el calificativo de posmodernas ${ }^{67}$. Aquí es oportuna la advertencia de Wellmer:

La palabra "post" forma parte de una red de conceptos y formas de pensamiento "postísticas" sociedad post-industrial, post-estructuralismo, post-empirismo, post-racionalismo- en los que al parecer trata de articularse la conciencia de hallarse en el umbral de una época cuyos contornos son aún confusos, poco claros y ambiguos, pero cuya experiencia central sin embargo -la muerte de la

\footnotetext{
${ }^{67}$ Se empleará este concepto de acuerdo a su problematización en Albrecht Wellmer, sin pretender en modo alguno formular juicios categóricos sobre los ámbitos concretos en que puede ser aplicado, sino en atención a que buena parte de la teoría desarrollada por el autor proporciona referencias y herramientas muy acordes con la propuesta estética de De Greiff. No se busca reivindicar para la escritura más avanzada de este poeta, sin reparo alguno, el calificativo de "posmoderna", sobre todo cuando aún no sabemos del todo qué refiere en concreto este concepto ni cuáles son sus tensiones fundamentales respecto a lo que llamamos "modernidad". No obstante, es claro que su estética más avanzada no responde a ciertas bases fundamentales de la tradición moderna, como la convicción del sujeto autónomo y su configuración estable en la escritura. Por ello, para efectos de su articulación en el pensamiento de Wellmer, y sólo respecto a su sección más vanguardista de desarticulación del Yo -no sobra insistir-, se la interpretará en el marco de esas tendencias heterogéneas, aún no definidas por completo, que formulan la transgresión de presupuestos básicos de la modernidad o un distanciamiento de su manera de entender la naturaleza y la relación de los elementos constitutivos del arte y el pensamiento, y que el autor, en este caso, entiende e integra bajo el concepto general de "posmodernidad". Por lo demás, no se ahondará en la controversia sobre el carácter de esta posmodernidad como "superación" de la modernidad o como "intensificación" de ella, pues para el caso basta con comprender, tal cual sucede en ambas hipótesis, que se trata de un momento de crítica y distanciamiento de muchos rasgos fundamentales de la modernidad según la noción tradicional que de ella ha predominado en la historia del pensamiento, ya se trate ésta de una etapa irrevocablemente cuestionada y dejada a un lado, o de un proceso que en la actualidad se revela en dinámicas no sospechadas en otras épocas.
} 
razón- parece apuntar al final definitivo de un proyecto histórico: el proyecto de la modernidad, el proyecto de la Ilustración europea, o incluso, por último, el proyecto de la civilización grecooccidental.

(Wellmer 51)

Lo que debe examinarse es el grado de participación de la obra de De Greiff en ese estado de la estética y el pensamiento contemporáneos definidos por la "experiencia central” de la "muerte de la razón", signo del "final definitivo" del proyecto de la modernidad, que se remonta en el tiempo hasta sus orígenes en la cultura griega y se extiende en el espacio a todos los confines del mundo en que la civilización occidental ha tenido presencia y se ha desarrollado. En principio, la escritura del descentramiento en De Greiff, no comprensible en la estética del modernismo y caracterizada por la fragmentación, la discontinuidad y la convergencia de lo uno y lo múltiple, parece comportar ciertos elementos que se vinculan, mucho más que implícitamente, a algunas tendencias recurrentes en el estado de la cultura contemporánea asociada por muchos autores con el concepto de la posmodernidad. En el conjunto de autores que Wellmer reseña, a modo de panorama general de la comprensión de lo posmoderno, hay conexiones más que evidentes entre muchos de los postulados allí referidos y los elementos más avanzados de la poesía en De Greiff examinados hasta ahora. En efecto, definiciones de posmodernidad como la disgregación de sujeto, razón y unidad de sentido en Ihab Hassan, la integración de lo diferente y múltiple en Frederic Jameson, la renuncia a la razón totalizadora en vías de la negación de la representación en Lyotard, o el juego de signos y fragmentos en favor de la multiplicidad y la contradicción en Charles Jencks y Robert Venturi, dan cuenta de tópicos también propios de la estética más avanzada del poeta, ya descritos y analizados con detalle (Wellmer 53-60). Pero respecto al problema del sujeto y la razón propiamente dichos, que es el eje fundamental del análisis del autor, encontramos vínculos mucho más concretos que evidencian en perspectiva estética amplia el lugar de esta poética en el conjunto de esas tendencias contemporáneas. Planteada la “constatación de la impotencia fáctica o la inexistencia del 'sujeto' autónomo" en Freud, y por tanto la "comprobación de la irracionalidad fáctica de su aparente 'razón""68, se formula en breves términos la tesis de esta crítica psicológica, y por la misma vía, el contexto de "descentramiento" en que se enmarcan tendencias literarias como la poética de avanzada en De Greiff:

\footnotetext{
${ }^{68}$ Wellmer 74; las cursivas, como en todas las citas en adelante, son del texto.
} 
El sujeto "des-centrado" del psicoanálisis es, en otras palabras, una encrucijada de fuerzas psíquicas y sociales antes que dueño de esas fuerzas; platea desde la que asistir a una cadena de conflictos, antes que director de un drama o autor de una historia. Pero no sólo el psicoanálisis, también la literatura de nuestro siglo ha aportado abundante material para la fenomenología de ese sujeto descentrado. De todas maneras, en los experimentos de la vanguardia literaria que, en expresión de Axel Honneth, "tratan de demostrar estéticamente la constricción del sujeto en el interior de un acontecer que sobrepasa su horizonte individual de sentido", se entrecruzan temas de una crítica psicológica del sujeto con otros de filosofía del lenguaje. (Wellmer 75)

A través de la idea del sujeto descentrado, en su caracterización por parte de este autor, De Greiff se inscribe en esos "experimentos" vanguardistas que trascienden el ámbito estético para entrecruzar "temas de una crítica psicológica del sujeto con otros de filosofía del lenguaje”. Esta es, ni más ni menos, la evidencia de la soberanía respecto a otros discursos de la modernidad, lo cual, en palabras de Menke, sólo es concebible desde el espacio propio de la autonomía. El discurso moderno problematizado por la crítica psicológica se refiere a premisas fundamentales que sustentan el aparato entero del pensamiento ilustrado y del "proyecto" por él consolidado y sistematizado. Desde este principio de crítica del sujeto y la razón, y su posterior desarrollo en otros ámbitos del pensamiento, es posible acceder a un contexto general de crítica a la tradición moderna, en el que De Greiff, con su poética más avanzada, participa de modo paradigmático, por medio de una dialéctica de autonomía y soberanía que en su caso proviene de la dialéctica de modernismo y vanguardia. Así pues, según Wellmer, más allá de los ulteriores desarrollos de las teorías psicoanalíticas de Freud, enmarcadas en la idea ilustrada de "humanidad decepcionada, desilusionada, al fin entrada en razón, una humanidad dueña de sí misma dentro de unos límites", su descubrimiento es irrevocable en la modificación de algo que no logra resolver, las categorías básicas de "sujeto, razón o autonomía en cuanto conceptos normativos":

[...] lo que es seguro es que ya no podían ser los conceptos de la filosofía del sujeto cartesiana o idealista; ni tampoco la suposición idealista de una voluntad de verdad como alternativa inteligible al principio del placer o a la voluntad de poder, de un diálogo sin violencia como alternativa inteligible a la violencia simbólica, o de autodeterminación moral como alternativa inteligible a la economía de la libido". (75) 
La crítica del sujeto se radicalizaría en la crítica a la razón instrumental y a la lógica de la identidad. Los "procesos de racionalización en la sociedad moderna -burocracia, derecho formal, instituciones formalizadas en la sociedad y la economía modernas-", en cuanto manifestaciones de la "razón unificadora, objetivadora, controladora y disciplinaria", son aplicaciones de una lógica formal que, a diferencia de lo que parecía proponerse el progreso hacia la razón, no es ya "un Organon de la verdad, sino el miembro intermedio entre el 'principio yoico sistematizador' y el concepto, que 'arma' y 'zanja”’ (77). Así, para Adorno y Horkheimer "el sujeto unitario, disciplinado e internamente regido sólo es correlato de la razón instrumental en un sentido temporal", desde el momento en que ese sujeto, "antaño soporte de la ilustración, se torna superfluo", desde que el ser humano, según la cita de la Dialéctica de la ilustración, "se desinfla hasta quedar convertido en mero nudo de enlace entre reacciones y funciones convencionales que se esperan de él en función de la objetividad" (Wellmer 78). Pero en esa perspectiva, "la desintegración de ese sí mismo unitario en la sociedad industrial tardía" no implica exactamente un sujeto autónomo destruido en el sentido de Freud, "sino más bien, en el sentido de Foucault, el correlato o producto del 'discurso de la modernidad': una forma disciplinada y disciplinar de organización del ser humano como ser social. Es violencia y no un acto de autoconstitución autónoma lo que hay en el origen de ese sí mismo unitario" (Wellmer 79). El sujeto unitario en el sentido de Adorno y Horkheimer, como explícitamente en el de Foucault, no puede, en rigor, ser destruido en el plano de su autonomía, por la simple razón de que jamás ha sido una entidad autónoma, sino sólo el producto de la cohesión social impuesta por la tradición moderna. Esta es la radicalización de la crítica al sujeto como presupuesto de la razón moderna en el pensamiento de Adorno y Horkheimer: el sujeto no es unitario ni autónomo, sino que nace desintegrado en esa realidad que pretende dominar mediante el concepto y su lógica de la identidad. Pero incluso, en la confrontación de la crítica de la razón instrumental con la filosofía del lenguaje, según Wellmer, esa crítica adolece del “'olvido del lenguaje' del racionalismo europeo", en cuanto es "secretamente psicológica", "pensada en términos intencionales, y por eso se nutre aún calladamente del modelo de un sujeto 'constituyente de sentido' que se enfrenta en su singularidad trascendental a un mundo de objetos" (80). Así, la lógica de la identidad sigue basándose en el modelo de subjetividad intencional de una razón justamente "instrumental”, que operaría con plena 
conciencia la modificación de un estado concreto de la realidad, algo que es cuestionado por la crítica de la filosofía del lenguaje: "incluso la razón instrumental se muestra en el fondo como praxis comunicativa que, en cuanto constituyente de la vida del sentido lingüístico, no admite ser reducida $n i$ a manifestación de una subjetividad que se sostiene a sí misma, ni tampoco de una subjetividad constituyente del sentido" (80). Entonces, la crítica fundamental está en el cuestionamiento de las bases comunicativas del lenguaje en las que se formaría la enunciación subjetiva del concepto como regulador de la naturaleza, según las entiende la tradición de la modernidad, en favor de un concepto amplio y problemático de lo que en la filosofía del lenguaje implica la "praxis comunicativa". La crítica psicoanalítica desintegra el sujeto autónomo, la crítica de la razón instrumental pone en evidencia su origen no autónomo, y la crítica del lenguaje derrumba todavía más la posición de preeminencia de la subjetividad en la regulación de la naturaleza proyectada por la modernidad. Un modelo de lenguaje que no comporta de modo alguno el presupuesto de un sujeto autónomo, unitario y diferenciado, es ese modelo que crea ruptura no sólo con la tradición del racionalismo, sino con "el proyecto de la modernidad, el proyecto de la Ilustración europea, o incluso, por último, el proyecto de la civilización grecooccidental" (51). El esquema de Wellmer, que sintetiza los problemas de la idea del sujeto moderno en la historia del pensamiento del siglo XX, es un marco adecuado para evaluar la naturaleza de las vanguardias y el arte contemporáneo en general, por cuanto proporciona el correlato filosófico y la definición de muchas tendencias que se originaron en el inicio de aquellas manifestaciones. La poesía en De Greiff reivindica el espacio de su autonomía, sin cerrarse por ello a su propio ámbito estético, sino extendiendo su alcance a la crítica soberana de otros modos del discurso de la modernidad. Esta soberanía se logra en la desintegración del sujeto autónomo a merced de las fuerzas contradictorias de la enunciación, en la crítica a su carácter unitario y diferenciado con la fragmentación del Yo en múltiples subjetividades y puntos de fuga hacia esa realidad "externa" que en la escritura se fusiona y confunde con él. La entidad del sujeto lírico es así una simple convergencia temporal de significaciones, un estado fugaz de enunciación que él no domina sino que, por el contrario, lo arrastra a él mismo en el fluir incesante y eternamente mutable de la escritura "diseminante". En el paradigma de esta escritura, como espacio de soberanía que presupone la autonomía, es fundamental la premisa del sujeto descentrado, no sólo en el sentido del psicoanálisis sino 
en el sentido que se ha abordado en todo este trabajo, ahora definido de acuerdo al esquema de la crítica de la modernidad en Wellmer: la crítica al "sujeto unitario, disciplinado e internamente regido", consolidado en la historia del pensamiento por la lógica formal de la "razón unificadora, objetivadora, controladora y disciplinaria"; la disolución del " "principio yoico sistematizador' y el concepto, que 'arma' y 'zanja"; el sujeto como "cadena de conflictos", “encrucijada de fuerzas psíquicas y sociales antes que dueño de esas fuerzas”, o "nudo de enlace entre reacciones y funciones convencionales"; carencia de intencionalidad clara y por tanto subjetividad que no "se sostiene a sí misma" ni "subjetividad constituyente del sentido". En fin, la crítica de la modernidad y de la tradición de la razón articulada en el logos, identificada por Wellmer en el centro mismo de lo que llama “posmodernidad", en la forma de la filosofía del lenguaje:

Aquí, se trata de la destrucción filosófica de las concepciones racionalistas del sujeto y del lenguaje; y en particular, de la imagen de que el sujeto sería, con sus vivencias e intenciones, la fuente de las significaciones lingüísticas. En lugar de lo cual se podría hablar también de una crítica de la "teoría nominal" de la significación, en el sentido de Wittgenstein: la imagen criticada es la de que el signo lingüístico alcanzaría significación al coordinar alguien - un usuario del signo- algo dado -cosas, clases de cosas, vivencias, clases de vivencias, etc.- con un signo, es decir, cuando alguien conectara un nombre con alguna clase de significación “dada”. Una teoría nominal de la significación de ese tipo parece estar profundamente anclada en la conciencia -o incluso en la preconciencia- de la filosofía occidental; continúa surtiendo efectos incluso en el empirismo radical hasta Russell. Llamo "racionalista" a esta teoría del lenguaje porque, implícita o explícitamente, descansa sobre el primado de un sujeto que da nombre y constituye el sentido, y porque participa, nolens volens, de una serie de idealizaciones de la tradición racionalista - en particular de la cosificación de las significaciones como "disponibles de antemano" (vorhanden) - que bastan para unirlas por encima de las restantes diferencias entre racionalismo y empirismo. (Wellmer 81)

La escritura que llega a confrontar los presupuestos básicos de la modernidad es entonces una escritura que rechaza la instancia del sujeto como principio estable y autónomo de la enunciación, y formula su existencia como la única realidad posible, donde se entremezclan significaciones que en la tradición moderna generarían identidades diferenciadas respecto a los seres humanos y a los demás seres y objetos de la realidad. La "destrucción filosófica de las concepciones racionalistas del sujeto y del lenguaje", y "de la imagen de que el sujeto sería, con sus vivencias e intenciones, la fuente de las significaciones lingüísticas", es en 
De Greiff la destrucción estética, desde la literatura, de otros modos de discurso de la modernidad, efectuada desde el modelo de una soberanía que presupone la autonomía. La vanguardia, que introduce en el arte una crítica a la tradición de la modernidad desde los propios materiales artísticos, es en este caso énfasis en la crítica del sujeto centrado que constituye la médula del pensamiento y la cultura occidental, entendida según el modelo racionalista e ilustrado, y según Wellmer, incluso empirista. Es el cuestionamiento de una epistemología y una forma de entender la presencia del sujeto en el arte, que se construye sin pausa a lo largo de siglos, para empezar a manifestar su agotamiento a finales del siglo XIX. Y De Greiff no sólo desarrolla su idea descentrada del sujeto desde su poesía más temprana, más cercana a la dialéctica de modernismo y vanguardismo, sino que la prolonga y profundiza a lo largo de las décadas siguientes, hasta bien entrada la segunda mitad del siglo XX. Si bien es cierto que en un "mamotreto" como "Bárbara Charanga", publicado hacia mediados del siglo, son más frecuentes nociones y prácticas de avanzada en el lenguaje, en comparación con su primer volumen, también es cierto que en esta evolución no hay continuidad alguna, pues lo mismo se encuentran elementos vanguardistas en el primer volumen que elementos modernistas en el último. En este caso, la opción, de nuevo, es asimilar la discontinuidad también presente en la evolución misma de su obra, pero sobre todo, en atención a develar su poética más avanzada, la discontinuidad de su noción de la escritura, que se articula perfectamente en inquietudes estéticas y filosóficas no exploradas en el siglo XIX, sino ya propias de la época contemporánea y todavía problematizadas sin conclusiones terminantes. En esta noción de la escritura y sus implicaciones para la idea del sujeto descentrado está la participación soberana del poeta en su época y en la problemática de la cultura a la que pertenece. Su irrupción en el panorama de la literatura colombiana y latinoamericana implica el distanciamiento crítico de una concepción de la literatura y el lenguaje común a toda la tradición occidental, y en esta región en particular construida sobre la perduración de un orden señorial que a su vez asimila formas occidentales modernas, como la opción por la producción de materia prima en economías globales de división internacional del trabajo, o la idea de nación que las generaciones del Centenario retoman y aplican según sus intereses conservadores. La tradición occidental en Latinoamérica, igual que en Europa, no es a finales del siglo XIX -como tampoco lo es hoy- una formación diferenciada en el progreso continuo del orden social y filosófico del 
racionalismo, sino una convergencia de discontinuidades donde se cruzan convicciones finiseculares de autonomía con proyectos de literatura moralista y pedagógica, estructuras capitalistas con reminiscencias feudales por fuera de los centros urbanos, países industriales con países relegados a producción de materia prima en la economía mundial racionalizada. Por eso, la participación de De Greiff en su contexto social es evidente y los alcances de su crítica no dejan dudas al respecto, a diferencia de lo que piensa Cuartas al hablar de una "encrucijada del Yo" que operaría "una suerte de descontextualización con la realidad" en una "poesía que tiende hacia dentro de su lenguaje, substrayéndose a la percepción crítica de la realidad conflictiva colombiana o latinoamericana que le tocó vivir al poeta" (Cuartas, León de Greiff 133). Pues bien, es justamente esa "encrucijada del Yo", tan bien analizada por el autor en otros puntos de su argumentación, el lugar de "percepción crítica de la realidad conflictiva" de una sociedad conformada por ideas de la tradición moderna europea, costumbres señoriales instauradas por la Colonia durante los siglos XV, XVI y XVII, y un orden de concentración casi feudal de la tierra en el siglo XIX por las "oligarquías terratenientes" de las que habla Octavio Paz. Y la literatura, desde luego, no escapa a esa determinación histórica. La noción del sujeto que De Greiff confronta es la que pervive en la tradición de la modernidad asumida en Latinoamérica desde el ordenamiento legal y burocrático impuesto por la Corona, hasta los antecedentes y la asimilación final de los valores burgueses en las nuevas Repúblicas, según el planteamiento de Rafael Gutiérrez Girardot:

[La] recepción del código napoleónico [implementado en Latinoamérica desde mitad del siglo XIX, en adaptación de Andrés Bello, y con que se imponen los "principios racionales y capitalistas"] la preparó y acompañó la difusión del utilitarismo de Bentham y de la ideología de Destutt de Tracy tanto en España como en Latinoamérica. Lo que, para el caso, importa comprobar es que tanto la introducción del derecho civil napoleónico como la de las ideologías utilitaristas de Destutt de Tracy y de Bentham no solamente impusieron los principios de la sociedad burguesa, sino que conformaron la vida y mentalidad de las sociedades de lengua española. [...] "Sociedad burguesa" o "sociedad civil": este nombre designa primeramente un sistema de valores, los de los intereses privados, los de la utilidad, los del hedonismo, los del lujo, los de la riqueza, los de la "democracia", los que resumió Louis Philippe, el rey burgués, en la consigna "enriqueceos". Es un nuevo "horizonte de la vida", anterior y presupuesto de lo que se ha llamado la "clase burguesa" 69 .

\footnotetext{
${ }^{69}$ Gutiérrez Girardot, Modernismo 31. V. pág, 62, nota 37, en el presente trabajo.
} 
En la crítica al sujeto de la modernidad, sobre el cual se conforma la razón como proyecto ilustrado de alcance universal, está entonces la instancia de crítica a la sociedad de su tiempo, que sintetiza un desarrollo muy particular (como en todas las demás sociedades, europeas y latinoamericanas) de esa tradición del sujeto y la razón. Y la crítica, ignorada en ocasiones, está construida según el modelo de esa soberanía que presupone la autonomía, en términos de Menke. La vanguardia y el desarrollo del arte contemporáneo en nuestros países son del todo integrables en una tradición occidental que actualmente manifiesta tendencias de disolución de las seguridades del racionalismo y la ilustración; pero también es preciso integrarlos en el ámbito particular de sus sociedades para determinar el grado de crítica, o desarrollo de su instancia soberana, que ejercen en esas sociedades a través del material artístico. De Greiff participa de la vanguardia en la medida que enfrenta el modelo institucionalizado de una literatura agotada en los márgenes de una tradición occidental asumida a su manera por el centenarismo y un modernismo tardío ya epigonal, ambos en apariencia opuestos pero al final coincidentes en la ideología de una restauración señorial decimonónica. Pero por esa misma vía, la crítica estética se transforma en crítica de los supuestos fundamentales que dan sustento a esas expresiones institucionalizadas, es decir, la noción del sujeto autónomo y plenamente diferenciado en la tradición de la modernidad, y la enunciación como lugar estable en que aquél se configura a medida que configura la realidad externa a él. En la escritura teratológica de la discontinuidad y la convergencia de lo múltiple no existen semejantes identidades unívocas. Heterónimos y trozos de identidad momentánea que no alcanzan a adquirir nombre propio en la diseminación de la escritura “abierta" y "fluyente", convergen discontinuos en el retrato que el sujeto problemático hace de sí mismo, como ocurre en "Memorias, desventuras, venturas y aventuras de Bogislaus y su Escudero y su Escribano y su Espolique":

Por modo que profeso la paleografía simple y a derechas, Yo, El Escribano, para traducir e interpretar añejos protocolos, y la Docta Paleografía cancrizante y en reversa y a tuertas, cuando actúo y opero como Paleógrafo y paraleógrafo y leogreiffiano, para enrevesar confesioncillas, tergiversar cancionillas (naderías) -suyas dél y de Bogislaus y mías-, naderías insaboras, y para retorcer dislates, disparates y embelecos de nos, todellos sin maldita la gracia. Lo primero, las pseudoconfidencias, mejor no meneallo. Las naderías, contables o no... Pero sería dilatado definir qué son naderías y qué son dislates (y su reata) -en conjunto- o qué es o no es cada uno de los componentes plurales del 
binomio y de los ataharres y cauda apendicular dellos. Y como se tiene (además) que "definir es limitar" (y lo dijo el Divino Leonardo). Y se tiene (en más de además) que "toda definición es un Lugar Común", necesariamente. (Y esto último sí no recuerdo quién lo dijera. Alguien sería, pero yo no. Tampoco fue ninguno de los integrantes de la fanfarria discorde, ninguno de los compañeros Otrosyoes, Sosías o Dobles de Bogislaus y míos; tampoco ninguno de la Capilla de los Neo-Serapiones ni del Eremitorio de los Jopecón)”. (535-536)

Este es el tono y el sentido de vanguardia en una obra que demanda nuevas aproximaciones de acuerdo a sus peculiaridades. La ironía que descompone el Yo, la divagación discursiva y la fragmentación de identidades "internas" y "externas", dan vida a un sujeto descentrado que no es sino la propia vida del lenguaje. La escritura se conforma como fluir incontrolado que funde subjetividad y nociones de la realidad externa, y donde en consecuencia, la razón moderna, en su sentido tradicional, naufraga. Sólo hay lenguaje en esta enunciación que todo lo desdibuja. La indefinición es una constante y la lógica de la identidad diferenciada desaparece. Sólo hay diseminación de márgenes, transferencia de identidades, significados intercambiables. Sólo hay un proceso global, el proceso que cuestiona todos los procesos, el espacio de convergencia de todo lo desintegrado: la escritura. De tal modo se cumple la soberanía autónoma en el contexto de la vanguardia en De Greiff: destrucción del concepto tradicional del sujeto, base fundamental de la razón moderna y por tanto de la realidad exterior como "objeto" del "sujeto", en el marco de una institución literaria agotada en la recurrencia de formas decimonónicas, mediante una escritura "diseminante" que todo lo desestabiliza y lo reconfigura como su contrario, como "todo" y como "nada", en fin, como entidad escurridiza y multiforme que no existe más allá del lenguaje mismo. 


\section{CIERRE: EPÍLOGO}

De Greiff no puede ser comprendido en su totalidad a partir de los criterios de la literatura modernista, pues sus búsquedas y sus logros en materia de tratamiento de la subjetividad demandan un marco referencial más acorde con la vanguardia. Pero incluso este marco referencial no brinda las claves enteras para su análisis, pues la discontinuidad que defiende y pone en práctica hace que trascienda algunas propiedades de las vanguardias, al menos según las proclamas o los programas explícitos de éstas, empleados a menudo para definir las obras concretas de los artistas. Se explica de esa forma la indefinición sobre la ubicación de su obra en la literatura hispanoamericana. Sin una participación total en el modernismo ni en los programas explícitos del vanguardismo, y sin la perduración de su estilo en ningún autor posterior, su obra, enfocada en la indefinición y la discontinuidad, se revela ella misma como una indefinible discontinuidad que pone en problemas las clasificaciones preestablecidas en la historia de la literatura del continente. Por esa razón, es ocioso buscar semejanzas estéticas o conceptos historiográficos adecuados para describirla o clasificarla con toda exactitud. Esta obra sin paralelos -cuya "voz no es nunca un eco", según la apreciación de Andrés Holguín (153)- requiere una categoría distinta para su clasificación, incluso ser integrada en posturas de crítica del sujeto unívoco y la enunciación propias de corrientes posteriores y mucho más avanzadas del siglo XX. No existe en la literatura de entonces ni en la posterior nada que se le pueda asemejar o siquiera aproximar, y ante la inconveniencia de acuñar el nombre de una nueva escuela para un autor que no constituyó escuela ni perteneció a una en particular, sólo es posible asumir el carácter discontinuo de su poética e integrarla en espacios de estéticas convergentes. La convergencia es, sin duda, una categoría más adecuada para esta obra en su conjunto, que la de "modernista" o "vanguardista", aplicadas de modo unilateral, o la de "transición" entre ambas, demasiado abocada a la idea de continuidad para un poeta en que prima la discontinuidad. Se salvaguarda así la discontinuidad de la historia del arte que Franco Moretti recomienda tomar en cuenta en cualquier método historiográfico, y que Miguel Gomes cita en relación 
con el carácter de la poesía en De Greiff en el contexto de la literatura de su época, como característica del “"campo magnético” de la literatura, en la que fuerzas de equilibrio y desequilibrio son incesantes" ${ }^{\text {70 }}$. Una poética que se nutre de la convergencia de múltiples estéticas reelaboradas es más efectiva en la crítica a la tradición moderna del sujeto y el lugar unívoco de enunciación, que una estética que proclama, en claro ademán hegeliano, la conciencia del fin del arte y el papel mesiánico de su propia reelaboración. En esta convergencia debe situarse -en cambio, por ello y ahora sí- el carácter de vanguardia en De Greiff, tal como señala Carmen Luna Sellés, al asegurar que “de esa contradicción [de aceptación y parodia de diversos -ismos] y de su puesta en práctica desafiante surge la originalidad de este poeta; originalidad que le vincula con la vanguardia" (Luna Sellés 281). La convergencia es la propiedad más auténtica de una expresión que claramente ataca la tradición moderna de la literatura occidental, y a la vez trasciende la vanguardia de programas explícitos que después revelaron su contradicción al inscribirse ellos mismos en esa tradición moderna. La convergencia y la discontinuidad en esta obra son, precisamente, lo que la preserva de las contradicciones de la vanguardia en movimientos plenamente consolidados donde la práctica artística se articuló con proclamas estéticas muy explícitas. No hay movimiento vanguardista en particular que pueda otorgar por completo los conceptos exactos para clasificar esta escritura y su concepción completamente descentrada

\footnotetext{
${ }^{70}$ Gomes 421 . Ahora bien, esto no significa que la indefinición inherente a los ismos y su carácter de progreso contradiga su existencia en la historia de la literatura como hito fundamental de principios del siglo XX. Es preciso dilucidar las contradicciones de la vanguardia con respecto a las intenciones de sus programas, pero también es preciso reconocer que su existencia se produce en el marco de una modificación profunda e inobjetable de nuestras ideas sobre el arte contemporáneo. Por ello, el hecho de que no exista un movimiento de vanguardia capaz de integrar a De Greiff no significa que su obra no tenga un carácter de vanguardia, como parece derivarse de los argumentos de Gomes, ni mucho menos que responda mejor a la corriente modernista, como se deriva de los argumentos de casi todos los que no encuentran en ella sus elementos de avanzada. Esto puede derivar $-\mathrm{y}$ lo ha hecho- en un equívoco respecto a la modificación que el poeta introduce en la literatura de su época, más asociada con la vanguardia que con una simple reelaboración del modernismo, como han planteado muchos. Pero su vanguardia debe ser revalorada y definida a partir de sus peculiaridades, en atención a lo que significó en la tradición de la literatura colombiana e hispanoamericana, así ello implique el intento por definir otra clase de vanguardia exclusiva para él, algo que podría proponerse aquí con más precisión, si no fuese por las vicisitudes propias de las clasificaciones. No obstante, avanzando un poco en tal sentido, hay que decir que el "sinfonismo" propuesto por Juan Felipe Toruño y Stephen Mohler es sólo una de las muchas posibilidades, referida en particular a la articulación de poesía y música en formas sin precedentes, que incorporan no sólo ritmos -como en toda la poesía existente-, sino más propiamente un repertorio de términos y estructuras musicales en composiciones ambivalentes; más allá de ello, de ser posible formular otros calificativos para otros elementos de avanzada, podría concebirse la estética de la convergencia aquí estudiada como una suerte de "fragmentismo" o "discontinuismo", por cuanto implicaría desarticulación y desintegración de los componentes usuales de la enunciación, como sujeto u objeto identificados en el mensaje, y su convergencia casi azarosa en conjuntos descentrados. Es sólo un ejemplo. La vanguardia en De Greiff, tan heterogénea como toda su obra, permite esto y mucho más.
} 
y discontinua de los modos y componentes de la enunciación. Es precisa la definición de otra forma de vanguardia, en un deslizamiento de la crítica hacia las particularidades de esta escritura. Por lo demás, es lo mismo que demanda el análisis de toda manifestación de vanguardia en nuestro continente: reducción del enfoque excesivo en el aparato conceptual que los artistas tenían sobre ellos mismos y sus prácticas, un poco falseado por la innegable influencia de proclamas europeas en contextos sociales muy diferentes, y todavía más por esa condición que define al presente, la de no poder aislarse de su propia situación para contemplarse desde una perspectiva histórica.

En De Greiff, el distanciamiento de la poética finisecular empieza con la inversión de nociones como la autosuficiencia del arte o las correspondencias del simbolismo, a través de la ironía contra la poesía y el poeta mismo. Ya no hay concepciones sagradas del arte, sino prácticas totalmente secularizadas que el poeta mismo contribuye a escarnecer. En el ejercicio de una ironía no eventual sino consustancial a la expresión, el sujeto se fragmenta y los trozos resultantes adquieren múltiples formas y modos de enunciación: heterónimos, sujetos colectivos, identidades anónimas, formas momentáneas que no alcanzan a recibir nombre, subjetividades intercambiables o transferibles a objetos "externos", todo surgido, integrado, fusionado, desintegrado, diseminado, configurado de nuevo en formaciones diferentes, bajo el signo de la multiplicidad, la contradicción y la mutación incesante. Más que "seudónimos" o simples "heterónimos", son éstos avatares del Yo, que integran incluso esa formación insólita del "Ene menos Uno" o del "Yo También Por Qué No He De Hacer Como Que Hago Versos". Los avatares del Yo no implican solamente una subjetividad fragmentada, sino ante todo un proceso sin fin de mutación e imbricación de identidades dispersas, afectadas por las vicisitudes de un sujeto discontinuo. La discontinuidad, nutrida de lo provisional y lo contradictorio, es modelo "paradigmático" de creación, distante del modelo "sintagmático" de la enunciación tradicional. En este escenario se representa el "montaje" de subjetividades, la superposición de Yo provisionales que, cada uno desde su centro provisional, configuran "paradigmas" de la unicidad en la multiplicidad. El sujeto descentrado se disemina en una escritura que se alimenta de sí misma, pues la ruta de la enunciación pierde sus referentes estables de "inicio" o "destino", al convertirse la divagación discursiva en único rumbo de la intención comunicativa que así se ve anulada. 
La diseminación en la escritura desdibuja los límites precisos del "sujeto" y el "objeto" constituido por la realidad "exterior", ya que al disgregarse el sujeto se disgrega también esa realidad que se configura a través del discurso. Sin sujeto no hay objeto. Este sujeto, la enunciación misma, es "hervidero" donde todo brota indiscriminadamente, "fárrago" donde todo se entremezcla, "verborragia oceánica" en que todas las identidades naufragan. La escritura se hace redundante, tras dibujar rutas enrevesadas que terminan por contradecirse o anularse en divagaciones. La teratología escritural fomenta el brote incesante de sujetos y objetos fugaces. Todos los elementos de la realidad se convierten en estados momentáneos de enunciación. Hay una "desubjetivación” y una "desobjetivación” simultáneas. El Yo de la escritura lo abarca todo, pero al recibir dicha ampliación se disuelve en la abundancia de enunciación de la que forma parte: es "sí mismo", pero también lo "otro", todo "lo demás". Esta es la crítica soberana, en el marco de la autonomía que es condición de su posibilidad, de toda una tradición de la modernidad basada en la idea del sujeto estable y unívoco, así como en el dominio del "objeto" externo a él mediante un concepto inamovible que ejerce su coacción; y por la misma vía, la crítica de una institución literaria hispanoamericana dependiente no sólo de esa tradición, sino también de nociones que prolongan la ideología señorial y estática de las oligarquías terratenientes. Este es el sentido de la vanguardia en De Greiff: la teratología de una escritura discontinua en que convergen los avatares del sujeto desintegrado, a favor de nociones ya plenamente contemporáneas que problematizan los fundamentos de la institución literaria y el medio intelectual del contexto de su época.

La caracterización vanguardista que presenta este trabajo es una de tantas reconstrucciones posibles de los múltiples trozos que De Greiff deja dispersos en su escritura. No se pretende que sea la única, como ya se ha advertido, pero tampoco que se niegue su plena existencia, ya corroborada, y cada vez más, con marcos teóricos amplios y perfectamente aplicables a su escritura. Es muy fácil tomar poemas célebres, citados por públicos amplios que no han profundizado en las secciones de avanzada más difíciles de esta extensa y contradictoria obra literaria, o recurrentes en comentarios de paso que sólo prolongan de manera simplista el corpus "crítico" más tradicional que existe sobre ella, y corroborar su sentido modernista. Sin embargo, tras décadas de trabajo en interpretaciones que profundizan en su sentido de vanguardia, con marcos teóricos más rigurosos que los del simple comentario periodístico 
disfrazado de juicio crítico fundamentado, ya no es posible, o al menos procedente, atenerse a parámetros tradicionales insuficientes desde todo punto de vista, como se ha dicho, para interpretar muchos procedimientos que superan ampliamente sus reducidos horizontes. Este trabajo se presenta como un avance en esa dirección hacia interpretaciones más amplias, tomando como presupuesto la multiplicidad estética que presenta esta obra y asimilando en principio la contradicción inherente a ella. Conceptos aquí formulados y desarrollados, como convergencia, discontinuidad, montaje de subjetividades, estados momentáneos de la enunciación, Yo provisionales, avatares del sujeto y escritura de la teratología, pueden ser la base de estudios posteriores que continúen indagando no sólo en este poeta, sino en las diferentes expresiones de la vanguardia y los inicios de la literatura contemporánea en el continente, las cuales, por lo demás, lejos de ser simplemente homologadas a procesos exógenos, deben enmarcarse en nuestros contextos y ser valoradas, en principio, en marcos teóricos que nosotros mismos, con referentes históricos, filosóficos y estéticos, articulemos. Y hay que seguir replanteando el lugar que le otorgamos a De Greiff en este contexto, pues la ampliación de perspectivas para su interpretación no sólo contribuirá a perfilar cada vez más los componentes de su obra tan única y todavía generadora de múltiples significados, sino también las tendencias literarias y artísticas del continente durante el siglo XX, aún no definidas del todo y en espera de reelaboraciones críticas para integrarse en otros enfoques y redes de comprensión. 


\section{BIBLIOGRAFÍA}

\section{BIBLIOGRAFÍA PRINCIPAL:}

\section{Fuentes primarias:}

De Greiff, León. Nova et vetera. Bogotá: Tercer Mundo, 1973.

---. Obras completas. Medellín: Aguirre Editor, 1960.

\section{Fuentes secundarias:}

\section{Obras teóricas:}

Benjamin, Walter. Poesía y capitalismo: Iluminaciones II. Madrid: Taurus, 1972.

Bürger, Peter. Teoría de la vanguardia. Barcelona: Península, 2000.

Horkheimer, Max y Theodor W. Adorno. Dialéctica de la Ilustración. Madrid: Trotta, 1998.

Menke, Christoph. La soberanía del arte: La experiencia estética según Adorno y Derrida. Madrid: Visor, 1997.

Wellmer, Albrecht. Sobre la dialéctica de modernidad y postmodernidad: La crítica de la razón después de Adorno. Madrid: Visor, 1993.

\section{Estudios sobre León de Greiff:}

Cuartas, Juan Manuel. “León de Greiff: Problemática del 'Yo' en poesía”. Thesaurus 51.1 (1996). 111-133.

Estripeaut Bourjac, Marie. "Los Nuevos como vanguardia: Lenguaje generacional, historia e imaginario”. Thesaurus 54.3 (1999). 729-773.

Gomes, Miguel. 'El tiempo literario de León de Greiff”. Hispanic Review 70.3. 421-438.

Luna Sellés, Carmen. “León de Greiff: ‘ ¡Ni soy lo que ellos dicen... ni en lo que soy estoy!"”. Moenia 16 (2010). 267-284. 


\section{Estudios sobre autores, movimientos artísticos y épocas:}

Gutiérrez Girardot, Rafael. Ensayos de literatura colombiana. Vol. 1. Medellín: Unaula, 2011.

---. Modernismo: Supuestos históricos y culturales. Bogotá: Universidad Externado de Colombia, Fondo de Cultura Económica; 1987.

Paz, Octavio. Los hijos del limo. Barcelona: Seix-Barral, 1974.

Rojas, Sergio. “Sobre Gombrich y el arte contemporáneo”. Aisthesis 43 (2009). 203-212.

Romero, José Luis. Latinoamérica: las ciudades y las ideas. Buenos Aires: Siglo Veintiuno Editores, 2011.

Sarlo, Beatriz. "Vanguardia y criollismo: La aventura de Martín Fierro". Carlos Altamirano y Beatriz Sarlo, Ensayos argentinos: De Sarmiento a la vanguardia. Buenos Aires: Ariel, 1997. 211-254.

\section{BIBLIOGRAFÍA SECUNDARIA:}

Acosta, Pedro. "León de Greiff: la esfinge y la palabra". Arturo Alape, Valoración múltiple sobre León de Greiff. Santafé de Bogotá: Universidad Central, Casa de las Américas, 1995. 195-207.

Alvarado Tenorio, Harold. Literaturas de América Latina. Cali: Universidad del Valle, 1995.

Alzate Noreña, Luis. "Sobre unos versos de Leo Legris". Arturo Alape, Valoración múltiple sobre León de Greiff. Santafé de Bogotá: Universidad Central, Casa de las Américas, 1995. 169-184.

Anderson-Imbert, Enrique. Historia de la literatura hispanoamericana 2. México: Fondo de Cultura Económica, 1974.

Arciniegas, Germán. “Sobre León de Greiff”. Arturo Alape, Valoración múltiple sobre León de Greiff. Santafé de Bogotá: Universidad Central, Casa de las Américas, 1995. 6478.

Bagú, Sergio. "La economía colonial”. El marxismo en América Latina, ed. Michael Löwy. Santiago: LOM Ediciones, 2007. 252-255.

Baudelaire, Charles. Obras. Ed. y trad., Nydia Lamarque. Madrid: Aguilar, 1963. 
Buck-Morss, Susan. Walter Benjamin, escritor revolucionario. Buenos Aires: Interzona Editores, 2005.

Caballero, María. "León de Greiff en el contexto de la vanguardia colombiana (18951976)". Philologia 4.1 (1989). 67-83.

Charry Lara, Fernando. Lector de poesía y otros ensayos inéditos. S. c.: Debate, 2005.

---. “Los poetas de Los Nuevos". Revista Iberoamericana 50.128-129 (1984). 633-681.

Cobo Borda, Juan Gustavo. Historia portátil de la poesía colombiana (1880-1995). Santafé de Bogotá: Tercer Mundo, 1995.

Cuartas, Juan Manuel. “Autobiografía y labor deconstructiva en Fernando Pessoa y en León de Greiff'. Tesis sin publicar. Facultad de Filosofía, Universidad Nacional de Educación a Distancia. 1997.

Espinosa, Germán. Ensayos completos: 1968-1988. Tomo 1. Medellín: Universidad EAFIT: 2002.

Garavito, Fernando. "La musicalidad en la obra de León de Greiff". Arturo Alape, Valoración múltiple sobre León de Greiff. Santafé de Bogotá: Universidad Central, Casa de las Américas, 1995. 146-152.

García-Prada, Carlos. "La fuga inefable hacia Ulalume”. Arturo Alape, Valoración múltiple sobre León de Greiff. Santafé de Bogotá: Universidad Central, Casa de las Américas, 1995. 185-194.

Gil Jaramillo, Lino. "Posesión y goce del idioma”. Arturo Alape, Valoración múltiple sobre León de Greiff. Santafé de Bogotá: Universidad Central, Casa de las Américas, 1995. 414423.

Gómez, Eduardo. "León de Greiff: El lírico contra la lírica tradicional”. Arturo Alape, Valoración múltiple sobre León de Greiff. Santafé de Bogotá: Universidad Central, Casa de las Américas, 1995. 153-168.

Guillén, Nicolás. "León de Greiff, esta noche...". Arturo Alape, Valoración múltiple sobre León de Greiff. Santafé de Bogotá: Universidad Central, Casa de las Américas, 1995. 1012.

Holguín, Andrés. Antología crítica de la poesía colombiana: 1874-1974. Documento electrónico consultado el 3 de noviembre de 2012. Disponible en:

http://es.scribd.com/doc/40370658/Antologia-Critica-de-La-Poesia-Colombiana-de-

$\underline{\text { Andres-Holguin }}$

Jiménez Panesso, David, ed. Antología de la poesía colombiana. Bogotá: Norma, 2005. 
---. Historia de la crítica literaria en Colombia. Bogotá: Universidad Nacional de Colombia, Instituto Colombiano de Cultura; 1992.

---. Poesía y canon. Bogotá: Norma, 2001.

Loaiza Cano, Gilberto. “Los Arquilókidas (1922)”. Hubert Pöppel y Miguel Gomes, Las vanguardias literarias en Bolivia, Colombia, Ecuador, Perú y Venezuela: Bibliografía y antología crítica. Madrid: Iberoamericana, 2008.

Lyotard, Jean-François. La posmodernidad (explicada a los niños). Barcelona: Gedisa, 1987.

Maya, Rafael. Consideraciones críticas sobre la literatura colombiana. Bogotá: Voluntad, 1944.

Mantecón Ramírez, Benjamín. "León de Greiff: El tema del amor”. Cauce 14-15 (19911992). 419-466.

Medina, Álvaro. "López, De Greiff, Vinyes, Vidales y el vanguardismo en Colombia”. Las vanguardias literarias en Bolivia, Colombia, Ecuador, Perú y Venezuela: Bibliografía y antología crítica. Ed. Hubert Pöppel y Miguel Gomes. Madrid: Iberoamericana, Vervuert; 2008. 197-217.

Mejía Duque, Jaime. "La poesía esquiva y desdoblada en espejismo de León de Greiff”. Arturo Alape, Valoración múltiple sobre León de Greiff. Santafé de Bogotá: Universidad Central, Casa de las Américas, 1995. 97-120.

Mohler, Stephen. El estilo poético de León de Greiff. S. c.: Tercer Mundo, 1975.

---. “León de Greiff, poeta musical”. Thesaurus 39.2 (1974). 271-296.

Mutis, Álvaro. "León de Greiff 1895-1976. Intacta presencia". Documento electrónico consultado el 4 de noviembre de 2013. Disponible en:

https://www.tareanet.edu.co/wikitareanet/lib/exe/fetch.php/mi_amigo_leo_le_gris.pdf

Pöppel, Hubert y Miguel Gomes. Las vanguardias literarias en Bolivia, Colombia, Ecuador, Perú y Venezuela: Bibliografía y antología crítica. Madrid: Iberoamericana, 2008.

Rodríguez Sardiñas, Orlando. "León de Greiff: Imágenes y figuraciones de una poética de vanguardia". Anales de literatura hispanoamericana 1 (1972). 207-231.

---. "Motivaciones temáticas en la poesía de León de Greiff”. UN, Revista de divulgación cutural 12 (1973). 35-67. 
Rojas de la Espriella, Álvaro. "Era un hombre que disfrutaba la soledad a sus anchas". Arturo Alape, Valoración múltiple sobre León de Greiff. Santafé de Bogotá: Universidad Central, Casa de las Américas, 1995. 17-20.

Ruiz Gómez, Darío. "El funeral de un mito". Arturo Alape, Valoración múltiple sobre León de Greiff. Santafé de Bogotá: Universidad Central, Casa de las Américas, 1995. 276-282.

Sanín Cano, Baldomero. El oficio de lector. Caracas: Biblioteca Ayacucho, 1989.

Suardíaz, Luis. "León de Greiff en Weimar". Arturo Alape, Valoración múltiple sobre León de Greiff. Santafé de Bogotá: Universidad Central, Casa de las Américas, 1995. 121-145.

Tejada, Luis. Nueva antología de Luis Tejada. Ed. Gilberto Loaiza Cano. Medellín: Universidad de Antioquia, 2007.

Toruño. Juan Felipe. "Sinfonismo en la poesía de León de Greiff". Arturo Alape, Valoración múltiple sobre León de Greiff. Santafé de Bogotá: Universidad Central, Casa de las Américas, 1995. 319-327.

Uribe Ferrer, René. "León de Greiff”. Arturo Alape, Valoración múltiple sobre León de Greiff. Santafé de Bogotá: Universidad Central, Casa de las Américas, 1995. 283-298.

Vargas Osorio, Tomás. "Iniciación a la poesía de León de Greiff". Arturo Alape, Valoración múltiple sobre León de Greiff. Santafé de Bogotá: Universidad Central, Casa de las Américas, 1995. 53-63.

Verani, Hugo. "Las vanguardias literarias en Hispanoamérica". Lectura crítica de la literatura americana. Saúl Sosnowski, ed. Caracas: Biblioteca Ayacucho, 1997. 9-66.

Vidales, Luis. "Nueve poetas en uno. El polifacético León de Greiff". Arturo Alape, Valoración múltiple sobre León de Greiff. Santafé de Bogotá: Universidad Central, Casa de las Américas, 1995. 328-338.

Vitale, Luis. “América Latina: ¿feudal o capitalista?”. El marxismo en América Latina, ed. Michael Löwy. Santiago: LOM Ediciones, 2007. 454-461. 